



\section{UNIVERSIDAD DE LEÓN}

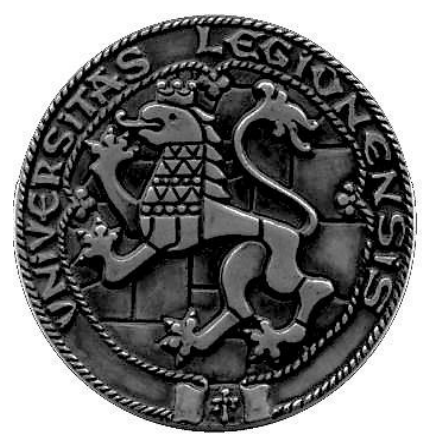

FACULTAD DE VERINARIA

Departamento de Higiene y Tecnología de los Alimentos

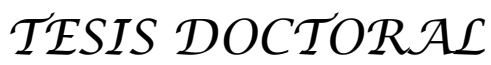

Enrichment on bioactive fatty acids of sheep milk cheese through the study and improvement of the factors involved in the technology of its production

Enriquecimiento en ácidos grasos bioactivos del queso de oveja a través del estudio y mejora de los factores implicados en la tecnología de su elaboración

ERICA RENES BAÑUELOS

León, 2018 



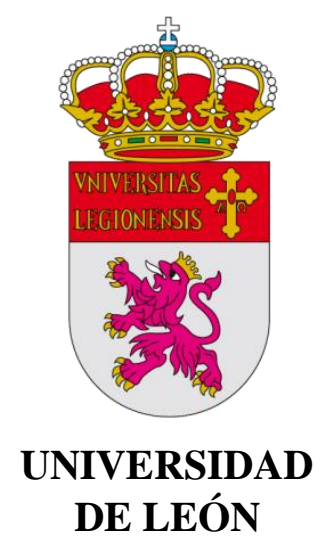

Memoria presentada para optar al grado de Doctor en el programa de doctorado "Ciencias Veterinarias y de los Alimentos" con Mención Internacional por la Universidad de León

\section{DOCTORANDO}

Erica Renes Bañuelos

Universidad de León

TUTOR Y DIRECTOR

Dr. José María Fresno Baro Universidad de León

\section{CODIRECTOR}

Dra. Ma Eugenia Tornadijo Rodríguez

Universidad de León 

"Science has not yet taught us if madness is or is not the sublimity of the intelligence"

Edgar Allan Poe (1809-1849)

"No es verdad que las personas dejen de perseguir sueños porque se hacen viejas, sino que se hacen viejas porque dejan de perseguir sus sueños"

Gabriel García Márquez (1927-2014) 



\section{Agradecimientos}

En primer lugar, quiero agradecer a mis directores de tesis, al Dr. José María Fresno y a la Dra. María Eugenia Tornadijo el darme la oportunidad de conocer el maravillosos mundo de la investigación y por la confianza que habéis depositado en mí a lo largo de estos años.

A la Universidad de León por la concesión del contrato predoctoral que me ha permitido realizar esta memoria de Tesis.

Mi más sincero agradecimiento a todos los miembros del Departamento de Higiene y Tecnología de los Alimentos de la Universidad de León, en especial a Bernardo por tu apoyo y por hacerme sentir como en casa. A Montse por tus consejos a lo largo de esta etapa y por hacerme reír tanto junto con Merche y Pepa en vuestras conversaciones. A Avelino por tu ayuda en Irlanda así como ahora de compañero de despacho. A Patricia porque contigo empecé mis andaduras en el laboratorio y agradezco mucho tus recomendaciones. A Leticia por tu apoyo a lo largo de estos años. A Julio por tu gran disposición a ayudarme siempre. A Domingo por las colaboraciones en el laboratorio. Sandra, gracias por tu amistad y por ser siempre tan positiva.

I would like to thank Dr. Catherine Stanton for giving me the opportunity to work with her research group at TEAGASC (Ireland). Daniel, a part of this thesis is thanks to you. Thanks to Carolina and Julia for making me feel like part of the family and for the friendship we have today. Raúl and Irene, thanks for your great friendship and support. I was very lucky to meet my dear French friends, Laure and Maeva, and my dear Burgalesa friend, Laura, in Ireland because this experience would not have been the same without you. Margaret and Sandra, thank you so much for all your help, friendship and always being ready to give me a hand. I hope to see you soon!

Llegados a este punto, los agradecimientos más importantes son para mi familia por el apoyo incondicional de todos y cada uno de vosotros (tanto los que están como los que dejaron una gran huella en mi). A Ángel y Ene, mis padres, por vuestro esfuerzo, porque he llegado hasta aquí gracias a vosotros, por escucharme, por vuestro apoyo, por vuestro amor incondicional,...... son tantas cosas las que os agradezco que no os lo podéis imaginar. A mi hermano, Adrián, por tu cariño, apoyo y por los grandes momentos que hemos vivido y que nos quedan por vivir. Os quiero mucho a los tres. Al amor de mi vida, Antonio, por tu paciencia y gran ayuda (tanto a nivel de laboratorio como personal) durante esta etapa. Gracias por apoyarme pase lo que pase y por hacerme feliz todos los días.

Gracias a todos porque sin duda este trabajo es parte de todos vosotros. 




\section{INDICE}

1.- INTRODUCCIÓN GENERAL

1.1.- Importancia de la leche y queso de oveja en la industria alimentaria

1.2.- Ácido linoleico conjugado ................................................................. 23

1.2.1.- Aspectos generales y biosintesis ............................................... 23

1.2.2.- Efectos fisiológicos del CLA y concentración de este compuesto en leche y queso ............................................................. 25

1.2.3.- Estrategias para incrementar el contenido en CLA de la leche y del queso

1.3. - Lactic acid bacteria and bifidobacteria with potential to design natural biofunctional health-promoting dairy foods

CAPÍTULO 1.- Effect of feeding regimen on the fatty acid profile of sheep bulk tank milk

CAPÍTULO 2.- Production of conjugated linoleic acid and gamma-aminobutyric acid by autochthonous lactic acid bacteria and detection of the genes involved

CAPÍTULO 3.- Study of the conjugated linoleic acid synthesis by Lactobacillus strains and by different co-cultures designed for this ability

CAPÍTULO 4.- CLA-producing adjunct cultures improve the nutritional value of sheep cheese fat

CAPÍTULO 5.- Production of sheep milk cheese with high $\gamma$-aminobutyric acid and ornithine concentration and with reduced biogenic amines level using autochthonous lactic acid bacteria strains 
4.1. - Estudio del perfil en ácidos grasos de leche de tanque procedente de granjas de ovino comerciales

4.2. - Estudio de la capacidad de cepas de bacterias ácido lácticas para producir CLA.

4.3. - Estudio de la capacidad de cepas de bacterias ácido lácticas para producir GABA " 158

4.4. - Diseño de co-cultivos constituidos por cepas de bacterias ácido lácticas con capacidad para sintetizar CLA 160

4.5. - Evolución de los parámetros físico-químicos y de los principales grupos microbianos de los quesos de oveja elaborados con diferentes cultivos productores de CLA a lo largo de la maduración

4.6. - Efecto de los cultivos productores de CLA y del tiempo de maduración sobre el perfil de ácidos grasos del queso de oveja

4.7. - Efecto de los diferentes cultivos diseñados sobre el perfil de aminoácidos libres, la microestructura y el contenido en aminas biógenas de los quesos a lo largo de la maduración 168

4.8. - Estudio de las características sensoriales del queso de oveja elaborado con distintos cultivos 


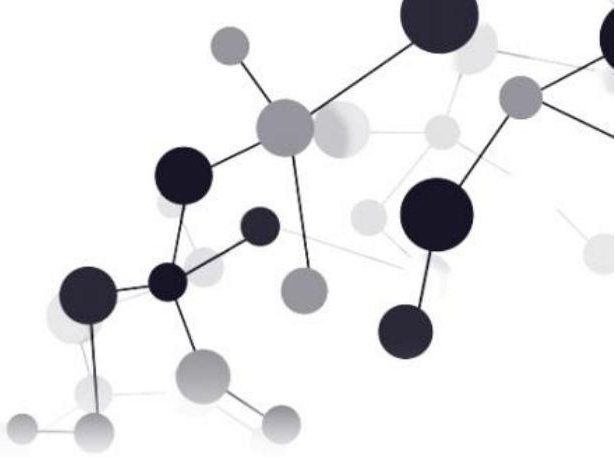



En la actualidad la creciente demanda de alimentos con efectos beneficiosos sobre la salud humana, está dando lugar a que en la industria alimentaria se tenga la necesidad de investigar nuevos métodos para satisfacer las exigencias del consumidor.

En este sentido, el queso, que supone un porcentaje importante del comercio agrícola mundial, ha suscitado en los últimos años una connotación negativa por parte del consumidor debido a la relación del contenido en ácidos grasos saturados de este alimento y el desarrollo de algunas enfermedades. Sin embargo, el queso también presenta compuestos con efectos beneficiosos sobre la salud del consumidor, como es el caso del ácido linoleico conjugado (CLA).

Ante la situación planteada, el objetivo general de esta Tesis Doctoral fue abordar la posible mejora del perfil nutricional del queso de oveja. En consecuencia, los métodos estudiados para alcanzar este objetivo abarcaron aspectos que van desde la producción animal hasta la tecnología de elaboración del queso.

En primer lugar, se estudió el efecto de la alimentación, de la etapa de lactación, del mes de muestreo y del rebaño en el perfil de ácidos grasos, con especial énfasis en el CLA, de la leche de tanque procedente de granjas de ovino comerciales. En este estudio se observó que en las granjas de ovino en las que se practicaba un régimen alimentario basado en un $50 \%$ de pastoreo, la leche de tanque que se obtenía presentaba mayor proporción de CLA $(1,16 \%)$ así como los mejores valores para la relación omega-6/omega-3 $(1,90)$ e índice de aterogenicidad $(1,59)$ en comparación con la leche de tanque procedente de granjas en las que a las ovejas no les era permitido el acceso al pasto $(0,79 \%, 3,41$ y 1,88 , respectivamente). Resulta oportuno indicar que el efecto de la etapa de lactación sobre la proporción de ácidos grasos presentes en la leche de oveja fue menos importante que el del resto de los factores estudiados ya que explicó menos del 4,18\% de la varianza.

En segundo lugar, es conocido el papel que pueden jugar los microorganismos durante la elaboración de los quesos en la mejora de su calidad nutricional y sensorial. Por ello, se analizó la capacidad para sintetizar CLA y ácido gamma-aminobutírico (GABA) en 85 cepas de bacterias ácido lácticas aisladas de quesos artesanales. Como resultado de este estudio se observó que seis cepas de Lactobacillus brevis y cuatro cepas de Lactococcus lactis subsp. lactis fueron capaces de sintetizar GABA en medio de cultivo suplementado con glutamato monosódico $(5 \mathrm{mg} / \mathrm{mL})$ y que la mayor concentración $(2524,05 \mu \mathrm{g} / \mathrm{mL})$ producida por estas cepas fue detectada tras $72 \mathrm{~h}$ de incubación. Así mismo, cuatro cepas de Lactobacillus plantarum y dos cepas de Lactobacillus casei subsp. casei fueron identificadas como productoras de CLA mediante detección espectrofotométrica de los dobles enlaces conjugados. Posteriormente, se analizó la capacidad de estas 6 cepas autóctonas para producir CLA en medio de cultivo y leche desnatada suplementados con ácido linoleico $(0,5 \mathrm{mg} / \mathrm{mL})$ bajo diferentes tiempos de incubación (24, 48 y 72 h). En particular, Lactobacillus plantarum TAUL 1588 fue la cepa que produjo la mayor concentración de los isómeros cis-9,trans-11 $\mathrm{C}_{18: 2}(23,73 \mu \mathrm{g} / \mathrm{mL})$, trans-10,cis-12 $\mathrm{C}_{18: 2}(3,37 \mathrm{\mu g} / \mathrm{mL})$ y trans-9,trans-11 $\mathrm{C}_{18: 2}(27,97 \mu \mathrm{gg} / \mathrm{mL})$ en medio de cultivo tras 48 h de incubación. Sin embargo, Lactobacillus casei subsp. casei SS 1644 fue 
la cepa que sintetizó mayor concentración de los isómeros cis-9,trans-11 C C18:2 $_{(18,33}$ $\mathrm{\mu g} / \mathrm{mL})$ y trans-9, trans- $11 \mathrm{C}_{18: 2}(35,05 \mu \mathrm{g} / \mathrm{mL})$ en leche desnatada.

En tercer lugar, y en base a la buena capacidad para sintetizar CLA por parte de estas dos cepas autóctonas de Lactobacillus, se diseñaron cuatro cultivos con posible aplicación en la elaboración de queso de oveja. En este estudio se observó que el cultivo compuesto por la combinación de estas cepas produjo la mayor concentración $(56,51$ $\mathrm{\mu g} / \mathrm{mL}$ ) de CLA en leche desnata suplementada con ácido linoleico. A su vez, los cultivos compuestos por cepas de Lactobacillus productoras de CLA en combinación con cepas de Lactococcus lactis autóctonas con adecuada aptitud tecnológica fueron más efectivos en la producción de CLA que los cultivos que incluyeron cepas comerciales de Lactococcus lactis y los Lactobacillus productores de CLA.

Finalmente, se elaboraron cuatro lotes de queso de oveja a partir de leche procedente de una de las granjas en la cual las ovejas fueron alimentadas bajo régimen de pastoreo y se emplearon diferentes cultivos constituidos por dos cepas autóctonas de Lactococcus lactis y las dos cepas de Lactobacillus mencionadas previamente. Cabe destacar que la combinación de estas cuatro cepas en el cultivo empleado en la elaboración de queso fue la que generó mayor concentración de ácido vacénico $(1,55 \%)$, CLA $(0,69 \%)$ y ácidos grasos omega-3 $(0,66 \%)$ sin apreciar cambios significativos en las características sensoriales en comparación con el lote control, elaborado únicamente con las cepas autóctonas de Lactococcus lactis. Así mismo, tras 240 días de maduración de los cuatro lotes de queso, se detectó una alta concentración de GABA (1296,75 mg/kg queso) y ornitina $(2355,76 \mathrm{mg} / \mathrm{kg}$ queso), los cuales se ha descrito que tienen efectos beneficiosos sobre la salud humana. De igual manera, se observó que el lote de queso que incluía la cepa Lactobacillus plantarum TAUL 1588 y las dos cepas autóctonas de Lactococcus lactis, mostró 2,37 veces menos de aminas biógenas que el lote que se elaboró con el cultivo que contenía las cepas de Lactococcus lactis pero no la cepa de Lactobacillus plantarum.

En definitiva, esta Tesis Doctoral demuestra la gran influencia que ejercen las prácticas de manejo del ganado ovino en el perfil de la grasa láctea así como la repercusión que tiene el empleo de cultivos lácticos seleccionados en función de su capacidad para sintetizar compuestos bioactivos con efectos beneficiosos sobre la salud humana en el desarrollo de productos lácteos con calidad nutricional mejorada. 
Currently, the growing demand for foods with beneficial effects on human health is generating the need to investigate new innovations in the food industry in order to meet the consumer demand.

In this context, cheese, which represents a significant percentage of the world agricultural trade, has generated a negative connotation on consumers in recent years due to the relationship between the saturated fatty acids in cheese and the development of some diseases. However, cheese contains other compounds that can improve the consumer health, such as the conjugated linoleic acid (CLA).

In the face of this situation, the general aim of this Doctoral Thesis was to study the potential for improvement of the nutritional value of sheep milk cheese. Consequently, the methods studied to achieve this aim included aspects related to the animal production and to the cheese-making process.

First, the effect of the feeding regimen, lactation stage, sampling month and flock on the fatty acid profile, with special emphasis on CLA, of bulk tank milk from commercial sheep farms was studied. It was observed that in sheep farms where a feeding regimen based on $50 \%$ grazing was practiced, the bulk tank milk had a higher proportion of CLA $(1.16 \%)$ as well as the improved omega-6/omega-3 ratio (1.90) and atherogenicity index (1.59) compared to the bulk tank milk from farms where sheep did not graze $(0.79 \%, 3.41$ and 1.88 , respectively). The effect of lactation stage on the fatty acid proportions of sheep milk was less important than that of the other factors studied, since it explained less than $4.18 \%$ of the variance.

Second, the role that microorganisms can play during the cheese-making process for the improvement of the nutritional and sensory quality of cheese is well known. Thus, 85 strains of lactic acid bacteria isolated from artisanal cheeses were studied to determine their ability to synthesize CLA and gamma-aminobutyric acid (GABA). It was observed that six Lactobacillus brevis and four Lactococcus lactis subp. lactis strains were able to produce GABA in culture medium supplemented with monosodium glutamate $(5 \mathrm{mg} / \mathrm{mL})$ and the highest concentration $(2524.05 \mu \mathrm{g} / \mathrm{mL})$ of GABA was found after $72 \mathrm{~h}$ of incubation. Likewise, four Lactobacillus plantarum and two Lactobacillus casei subsp. casei strains were identified as CLA-producers by spectrophotometric detection of the conjugated double bonds. Subsequently, the ability of these 6 autochthonous strains to produce CLA in culture medium and in skim milk supplemented with linoleic acid $(0.5 \mathrm{mg} / \mathrm{mL})$ under different incubation times $(24,48$ and $72 \mathrm{~h})$ was analyzed. In particular, Lactobacillus plantarum TAUL 1588 was the strain that produced the highest concentration of the isomers cis-9, trans-11 $\mathrm{C}_{18: 2}(23.73 \mathrm{\mu g} / \mathrm{mL})$, trans-10, cis-12 $\mathrm{C}_{18: 2}(3.37 \mathrm{\mu g} / \mathrm{mL})$ and trans9, trans-11 $\mathrm{C}_{18: 2}(27.97 \mathrm{\mu g} / \mathrm{mL})$ in culture medium after $48 \mathrm{~h}$ incubation. However, Lactobacillus casei subsp. casei SS 1644 was the strain that synthetized the highest concentration of the isomers cis-9,trans- $11 \mathrm{C}_{18: 2}(18.33 \mu \mathrm{g} / \mathrm{mL})$ and trans-9, trans-11 $\mathrm{C}_{18: 2}$ (35.05 $\mathrm{\mu g} / \mathrm{mL})$ in skim milk.

Third, based on the demonstration of the ability of these two Lactobacillus strains to synthesize CLA, four cultures were designed with possible application for the production of sheep milk cheese. In this study, it was observed that the culture including the 
combination of these strains produced the highest concentration $(56.51 \mu \mathrm{g} / \mathrm{mL})$ of CLA in skim milk supplemented with linoleic acid. Additionally, the cultures including these CLAproducing Lactobacillus strains in combination with the autochthonous Lactococcus lactis strains (with adequate technological aptitude) were more effective in CLA production than the cultures including commercial strains of Lactococcus lactis and the CLA-producing Lactobacillus strains.

Finally, four batches of sheep milk cheese were manufactured with the bulk tank milk from one of the farms in which sheep were grazed and using four different cultures, consisting on the two autochthonous Lactococcus lactis strains and the two CLA-producing Lactobacillus strains mentioned previously. Significantly, the combination of the four strains in the culture used for cheese-making produced higher concentrations of vaccenic acid $(1.55 \%)$, CLA $(0.69 \%)$ and omega-3 fatty acids $(0.66 \%)$ without appreciating important changes on the sensory characteristics compared to the control batch, which was produced only with the autochthonous Lactococcus lactis strains. Likewise, after 240 days of ripening, a high concentration of GABA $(1296.75 \mathrm{mg} / \mathrm{kg}$ cheese) and ornithine (2355.76 $\mathrm{mg} / \mathrm{kg}$ cheese) were detected in the four cheese batches. As has been described previously, these compounds have beneficial effects on human health. In addition, it was observed that the batch produced with the culture including the Lactobacillus plantarum TAUL 1588 strain and the two Lactococcus lactis strains, showed 2.37 fold reduced biogenic amines concentration with respect to the batch made with the culture including the Lactococcus lactis strains but not the Lactobacillus plantarum strain.

In conclusion, this Doctoral Thesis shows the great influence of sheep management practices on the fatty acid profile of milk as well as the repercussion from the use of lactic acid bacteria cultures selected for their ability to synthetize bioactive compounds, with beneficial effects on human health, on the development of dairy products with improved nutritional quality. 



\section{INTRODUCCIÓN GENERAL}

\subsection{Importancia de la leche y queso de oveja en la industria alimentaria}

La leche y los productos lácteos representan cerca del 14\% del comercio agrícola mundial. Tradicionalmente, la leche de vaca es la de mayor consumo suponiendo un $85 \%$ de la producción mundial de leche. Sin embargo, la producción láctea de pequeños rumiantes, como la leche de oveja, representa una parte importante de la economía agraria de varios países principalmente situados en la región Mediterránea y Oriente Medio. En 2015, la producción mundial de leche de oveja alcanzó 13 millones de toneladas, siendo los mayores productores: China (12\%), Turquía (8,5\%), Grecia $(5,5 \%)$, Rumanía (5\%) y España $(4,7 \%)(F A O, 2015)$. En España la comunidad con mayor producción de leche de oveja es Castilla y León con un 64\% seguida por Castilla-La Mancha con un 27\% (MAPAMA, 2016). La mayor parte de la producción de leche de oveja es destinada a la elaboración de queso. En este sentido, España abarca el 35\% de la producción de queso de oveja en la UE.

En la última década, los requisitos del consumidor en relación con los alimentos están cambiando. Los alimentos no son sólo utilizados para satisfacer el hambre sino además para prevenir enfermedades relacionadas con la alimentación y para mejorar la salud física y mental (Bigliardi y Galati, 2013). Como consecuencia, el desarrollo de alimentos que satisfagan estas nuevas necesidades del consumidor es de gran interés en la industria alimentaria. En este sentido, los productos lácteos elaborados a partir de leche de oveja, en especial el queso, han ganado amplitud de mercado debido a la calidad y al valor nutricional de los mismos. Este alto valor nutricional es debido a las mayores concentraciones de proteína, grasa, vitaminas y minerales presentes en estos productos lácteos en comparación con los elaborados a partir de leche procedente de otros mamíferos (Balthazar et al., 2017).

En lo que respecta a los ácidos grasos saturados presentes en el queso, éstos han adquirido una connotación negativa por parte del consumidor por su relación con el desarrollo de algunas enfermedades, principalmente de tipo cardiovascular (Elwood et al., 2010). Sin embargo, el queso, también presenta compuestos que pueden mejorar la salud del consumidor, como es el caso del ácido linoleico conjugado (Diana et al., 2014; Koba y Yanagita, 2014; Tanaka, 2005). Por consiguiente, el diseño de estrategias enfocadas a incrementar el contenido de estos compuestos bioactivos en el queso tiene un especial interés en el desarrollo de productos lácteos funcionales.

\section{2. Ácido linoleico conjugado}

\subsubsection{Aspectos generales y biosintesis}

El ácido linoleico conjugado (conjugated linoleic acid; CLA) hace referencia a un grupo de isómeros posicionales y geométricos del ácido octadecadienoico con un sistema de dobles enlaces conjugados. Ha sido descrito que estos dobles enlaces pueden encontrarse entre las posiciones 6-8 y 13-15 con 4 isomerías geométricas (cis-cis, cis-trans, trans-cis, trans-trans) (Sehat et al., 1998). La leche y los derivados lácteos son los que, de 
forma natural, aportan a la dieta la mayor cantidad de CLA, y según la especie animal, se ha observado que la grasa de la leche de oveja presenta una mayor concentración de CLA que la de vaca o la de cabra (Park et al., 2007). De todos los isómeros CLA presentes en la grasa de la leche, el cis-9,trans-11 $\mathrm{C}_{18: 2}$, también llamado ácido ruménico, es el más abundante ya que representa entre el 70 - 90\% del contenido total de CLA en la grasa láctea (Parodi, 1977). En los rumiantes la biosintesis del CLA, específicamente del isómero cis-9, trans-11 $\mathrm{C}_{18: 2}$, tiene lugar en el rumen (sintesis ruminal) y en la glándula mamaria (síntesis endógena) (Figura 1). En el rumen, el CLA se produce como intermediario de la biohidrogenación incompleta de los ácidos grasos poliinsaturados, específicamente del ácido linoleico y del ácido a-linolénico, por acción de las enzimas de distintas bacterias anaerobias ruminales, siendo Butyrivibrio fibrisolvens una de las bacterias más importantes implicadas en este mecanismo. En esta ruta biosintética, se produce en primer lugar la isomerización del doble enlace cis en posición 12 del sustrato (ácido linoleico o ácido a-linolénico), pasando a tener configuración trans en el carbono 11. En la siguiente etapa, el doble enlace en posición cis-9 experimenta una hidrogenación, formándose el ácido vacénico. Si la biohidrogenación fuese completa, el producto final sería el ácido esteárico pero esta bioconversión se ve parcialmente impedida por la gran estabilidad del doble enlace en la posición trans-11 (Jenkins et al., 2008; Kraft et al., 2003). Entre el 64 y 98\% del ácido ruménico presente en la grasa láctea es generado en la glándula mamaria por acción de la enzima $\Delta-9$ desaturasa sobre el ácido vacénico (trans$11 \mathrm{C}_{18: 1}$ ), el cual se ha observado que es un intermediario producido en la biohidrogenación ruminal (Rodríguez-Castañedas et al., 2011). Apenas existen estudios que detallen la biosíntesis de los otros isómeros del CLA debido a que estos no se encuentran en cantidades significativas en la grasa láctea y a que la funcionalidad de muchos de ellos aún no ha sido establecida (Gómez-Cortés, 2010).

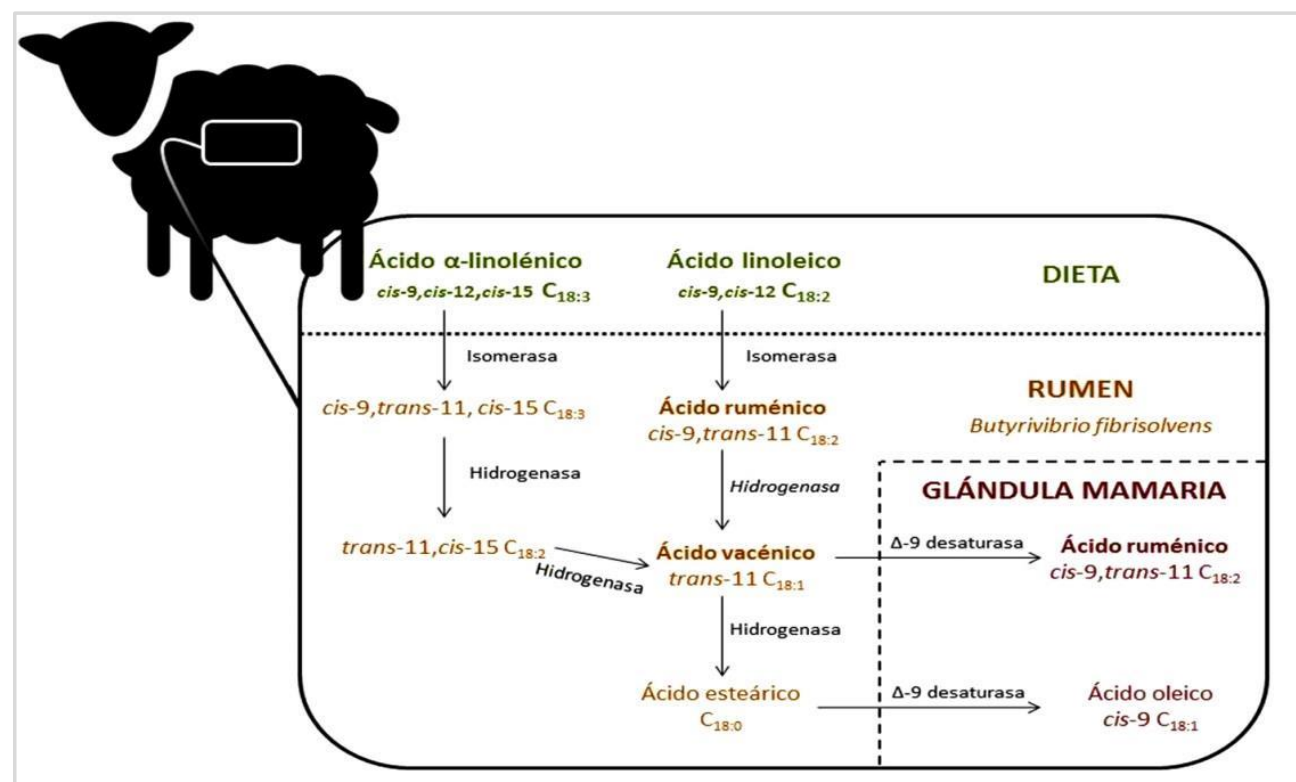

Figura 1. Biosintesis del ácido ruménico (cis-9,trans-11 $\mathrm{C}_{18: 2}$ ) en el rumen y en la glándula mamaria. Adaptada de Gómez-Cortés (2010). 


\subsubsection{Efectos fisiológicos del CLA y concentración de este compuesto en leche y queso}

El CLA ha suscitado gran interés por sus potenciales efectos beneficiosos sobre la salud, entre los cuales destacan los efectos anticarcinogénicos, antitrombogénicos, reducción de la aterosclerosis, estimulación de la mineralización ósea, modulación del sistema inmune, disminución de la resistencia a la insulina, reducción de la glucosa en sangre y de la grasa corporal (Lehnen et al., 2015). Se ha observado que la actividad biológica del CLA está relacionada en particular con dos isómeros: el cis-9, trans-11 C $18: 2$ y el trans-10,cis-12 $\mathrm{C}_{18: 2 .}$

El efecto fisiológico más estudiado del CLA es su capacidad para modificar la composición corporal, promoviendo la reducción de los niveles de grasa corporal, como un agente antiobesidad (Churruca et al., 2009). Los resultados iniciales fueron descritos en modelos animales (Botelho et al., 2005, Kloss et al., 2005); ahora bien, investigaciones más recientes en humanos sugieren que el CLA puede actuar reduciendo la grasa corporal modulando el metabolismo lipídico. Los posibles mecanismos de acción implican cambios metabólicos hacia la reducción de la lipogénesis y la mejora de la lipólisis (Martins et al., 2015).

La información disponible sobre los niveles de CLA requeridos para lograr este efecto fisiológico es limitada. Se ha descrito que la reducción de la grasa corporal puede observarse cuando tiene lugar una ingesta de CLA entre 3 y $6 \mathrm{~g}$ al dia (Iwata et al., 2007; Lehnen et al., 2015). Curiosamente, la ingesta de CLA durante un periodo inferior a 4 semanas en humanos no proporcionó efectos positivos en la reducción de grasa corporal (Pariza, 2009). Sin embargo, en estudios de más de 6 meses de duración, se observó una mayor eficacia del CLA en la modulación de la grasa corporal (Dilzer y Park, 2012).

Otro beneficio potencial del CLA es el efecto antidiabético. Se habla de efecto potencial porque sólo se han realizado estudios en animales, como por ejemplo, el llevado a cabo por Song et al. (2016) en el que se administró a ratones con diabetes tipo II, una leche fermentada que contenía CLA $(0,01 \%$ o $0,03 \%)$ durante 6 semanas. Como resultado de este experimento se observó que los niveles de glucosa en sangre en ayunas, insulina sérica y leptina disminuyeron significativamente en los ratones alimentados con la leche fermentada que contenía la mayor concentración de CLA en comparación con los ratones que recibieron placebo. Por consiguiente, estos resultados sugieren el posible desarrollo de productos lácteos con CLA como alimentos funcionales para contribuir al tratamiento de la diabetes mellitus tipo II (Song et al., 2016). Aun así, es conveniente indicar que sería necesario llevar a cabo estudios en humanos en relación con los posibles efectos antidiabéticos de este ácido graso bioactivo.

La capacidad anticarcinógena del CLA ha sido observada en modelos animales con tumores de mama inducidos químicamente, cuando se les administraba dosis de CLA entre el 0,5\% y el 1\% (Ip et al., 1994). En consecuencia, se ha tratado de conocer este efecto fisiológico en humanos a través de estudios epidemiológicos pero no ha sido posible extraer conclusiones claras sobre el efecto preventivo del CLA sobre el cáncer. A pesar de estas limitaciones, Pariza (2004) indicó que una persona de $70 \mathrm{~kg}$ tendría que consumir 3 g de CLA al día para conseguir los efectos beneficiosos que ejerce el CLA en la inhibición de la carcinogénesis mamaria. En cambio, Mohan et al. (2013) señalaron que una concentración inferior de CLA (0,42 g de CLA al día) a la recomendada por Pariza (2004) 
podría ser la dosis efectiva para alcanzar los efectos anticarcinogénicos descritos en humanos.

Cabe destacar que el contenido en CLA en leche y queso varía entre un 0,10\% y un $2,86 \%$ de los ácidos grasos totales (Tabla 1). Lo que quiere decir que la ingesta estimada actual de CLA en personas a partir de las fuentes alimentarias es insuficiente para obtener los efectos potenciales contra el cáncer, la aterosclerosis y la obesidad observados en los estudios in vivo (Watkins y Li, 2003). Por este motivo, se están realizando estudios para incrementar la concentración de CLA en la leche y en los productos lácteos, ya que sin duda puede repercutir de forma favorable en su calidad nutricional y por lo tanto en el valor añadido de los alimentos que lo contengan.

Tabla 1. Contenido total de ácido linoleico conjugado (g CLA/100 g ácidos grasos totales) en leche y queso.

\begin{tabular}{|c|c|c|c|}
\hline \multirow{2}{*}{ Alimento } & \multicolumn{2}{|c|}{ Intervalo de variación } & \multirow{2}{*}{ Referencia } \\
\hline & Minimo & Máximo & \\
\hline Leche de vaca entera & 0,41 & 0,93 & \multirow{2}{*}{$\begin{array}{l}\text { Ruiz et al., } 2016 \\
\text { De La Fuente et al., 2009; Tsiplakou } \\
\text { et al., } 2006\end{array}$} \\
\hline Leche de oveja entera & 0,79 & 2,00 & \\
\hline Leche de cabra entera & 0,40 & 0,62 & $\begin{array}{l}\text { Cossignani et al., 2014; Tsiplakou et } \\
\text { al., } 2006\end{array}$ \\
\hline Queso de vaca & 0,10 & 1,30 & El-Salam and El-Shibiny, 2014 \\
\hline Queso de oveja & 0,38 & 2,86 & El-Salam and El-Shibiny, 2014 \\
\hline Queso de cabra & 0,20 & 0,84 & El-Salam and El-Shibiny, 2014 \\
\hline
\end{tabular}

\subsubsection{Estrategias para incrementar el contenido en CLA de la leche y del queso}

\subsubsection{Producción animal}

Con el fin de modificar la composición en ácidos grasos de la leche de oveja para mejorar el perfil nutricional del queso, fundamentalmente a través del incremento de los niveles de CLA, es necesario conocer los diferentes factores que afectan al perfil lipídico de la misma. De todos ellos, el factor que más influencia tiene sobre el contenido en CLA de la leche es el tipo de alimentación proporcionada a los animales. En los últimos años se han llevado a cabo numerosas investigaciones para estudiar dicho efecto (Chilliard et al., 2007; Hervás et al., 2008; Kalač y Samková, 2010; Stanton et al., 2003). La clave para incrementar la concentración de CLA en la leche se encuentra en el aumento de la producción de ácido vacénico en el rumen, permitiendo de esta manera la síntesis endógena de CLA en la glándula mamaria. El incremento de la producción ruminal de ácido vacénico puede ser logrado de dos maneras: mediante el aumento del suministro de ácidos grasos poliinsaturados precursores, como es el caso del ácido a-linolénico, y por inhibición de la reducción del ácido vacénico en ácido esteárico, siendo la primera vía la más fácil de llevar a cabo (Lock y Bauman, 2004).

Se ha observado que la leche obtenida de animales alimentados a base de pasto fresco presenta mayor concentración de CLA que aquella obtenida de animales estabulados alimentados a base de ensilados o con dietas a base de concentrados (van Wijlen y Colombani, 2010). El uso incrementado en la alimentación de ensilados y concentrados, así como el abandono de la estacionalidad a favor de los sistemas de producción continua, son factores que afectan a la calidad del perfil lipídico de la leche 
de oveja (Pellattiero et al., 2015). En la región Mediterránea la mayoría de los sistemas de producción de ovino son semiextensivos, lo que significa que el pasto fresco juega un papel importante en la alimentación de los animales, el cual presenta un bajo contenido lipídico pero aproximadamente un $63 \%$ de este está constituido por ácidos grasos precursores del CLA (Cabiddu et al., 2005). De los anteriores planteamientos se deduce que el aumento del tiempo de pastoreo de los rumiantes puede ser una de las formas más importantes para incrementar la concentración de CLA en la leche (Tsiplakou et al., 2008). Así mismo, se ha observado que la concentración de este ácido graso en el pasto se ve principalmente afectada por la etapa fenológica en la que se encuentran las plantas que lo componen. En este sentido, se ha visto que en la etapa vegetativa presentan mayor concentración de ácido a-linolénico que en la etapa reproductiva. Esto puede explicar que, de manera general, los mayores niveles de este ácido graso se observen en pastos primaverales y, por consiguiente, que los rumiantes alimentados con ellos produzcan una leche con mayor concentración de CLA durante esta época del año que en cualquier otra (Rodríguez-Castañedas, 2012).

De La Fuente et al. (2009) han señalado que hay otros factores que también afectan en menor medida al perfil lipídico de la leche de ovino, tales como el rebaño, la edad, la etapa de lactación y el día de muestreo. A su vez, también hay diversos trabajos que han tratado de estudiar el efecto que ejerce la raza sobre el contenido en CLA de la leche. Tsiplakou et al. (2008) estudiaron el efecto de diferentes razas de ovino, bajo el mismo sistema de manejo y alimentación, sobre el contenido en ácidos grasos de la leche, concluyendo que la interacción entre la raza y la dieta tuvo un efecto significativo sobre la mayoría de los ácidos grasos, pero que la raza por sí misma no tuvo un efecto significativo sobre el contenido en CLA. Signorelli et al. (2008) en un estudio llevado a cabo para promover ciertas razas de ovino autóctonas, observaron diferencias significativas en el perfil lipídico de la leche de las diferentes razas estudiadas. Como puede deducirse de los resultados de estos trabajos de investigación, en este ámbito de estudio hay cierta controversia. Este hecho puede deberse a que como Lock y Bauman (2004) señalaron, estos trabajos a menudo incluian pocos animales en su estudio o no separaban bien el efecto que tiene la alimentación animal, haciendo necesario llevar a cabo más estudios para poder establecer si realmente la raza es un factor que puede condicionar el contenido en CLA de la leche.

La gran cantidad de investigaciones llevadas a cabo para estudiar los diferentes factores del sistema de manejo de los animales que puedan mejorar el perfil de ácidos grasos de la leche pone de manifiesto que las estrategias para mejorar el perfil lipídico de los productos lácteos deben comenzar desde el proceso de producción de la materia prima. Sin embargo, también resulta posible modificar el perfil de ácidos grasos de los quesos actuando sobre el propio proceso de elaboración, tal y como se describe a continuación.

\subsubsection{Tecnología de la elaboración: cultivos iniciadores o adjuntos}

Según lo descrito en mayor detalle en el apartado anterior, las bacterias presentes en el rumen son las principales responsables de la síntesis de ácido ruménico y de ácido vacénico a partir del ácido linoleico y a-linolénico procedentes de la alimentación animal. Este hecho ha llevado a varios investigadores a plantearse si 
otras bacterias frecuentemente utilizadas en la elaboración de productos lácteos fermentados, tales como las bacterias ácido lácticas o las bifidobacterias, serian capaces de sintetizar CLA a partir de ácidos grasos poliinsaturados como sustrato y de esta forma incrementar la concentración de este compuesto bioactivo en diversos productos lácteos (Gorissen et al., 2010; Nieuwenhove et al., 2007; Rodríguez-Alcalá et al., 2011; Terán et al., 2015).

En lo referente a la biosintesis del CLA a partir del ácido linoleico por las bacterias ácido lácticas, se ha observado que puede tener lugar aparentemente a partir de dos rutas metabólicas distintas: isomerización directa del ácido linoleico o vía ácido 10-hidroxi-octadecenoico (Figura 2).

En esta última ruta metabólica, tiene lugar una hidratación del ácido linoleico dando lugar a 10-hidroxi-cis-12- $\mathrm{C}_{18: 1}$ en equilibrio con 10-hidroxi-trans-12-C $18: 1$ seguida de una deshidratación e isomerización de estos ácidos grasos hidróxidos a CLA (cis-9, trans-11 $\mathrm{C}_{18: 2}$ en equilibrio con trans-9,trans-11 $\mathrm{C}_{18: 2)}$ (Andrade et al., 2012). Cabe destacar, que estas rutas metabólicas sólo son posibles si en los microorganismos se encuentra presente la linoleato isomerasa, la cual ha sido descrita por Ogawa et al. (2005) como un complejo enzimático constituido por tres enzimas que requieren cofactores redox como el NADH y o el FAD y que, a su vez, es dependiente de la cepa.

En este contexto, varios estudios han demostrado que diversas cepas principalmente pertenecientes a las especies Bifidobacterium, Lactobacillus, Lactococcus y Propionibacterium pueden transformar eficientemente el ácido linoleico en CLA en ensayos realizados en medio de cultivo o leche desnatada a los que se les añadió ácido linoleico como sustrato (Tabla 2).

A

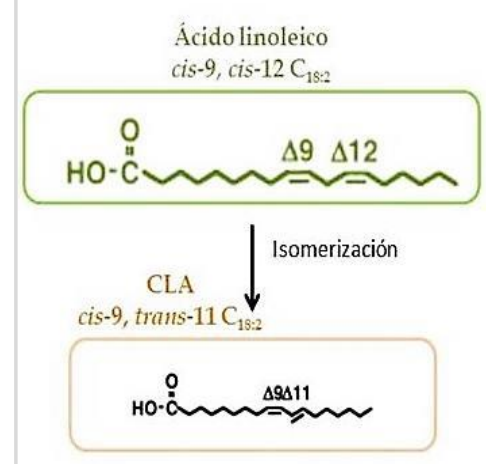

B

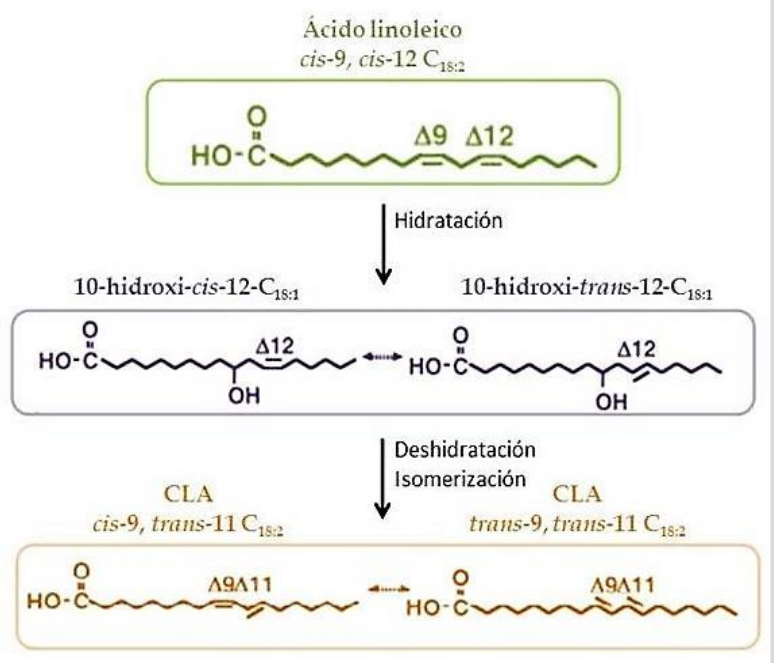

Figura 2. Rutas metabólicas propuestas en los microorganismos con respecto a la síntesis del ácido linoleico conjugado a partir del ácido linoleico. A: isomerización directa; B: vía ácido 10 hidroxi-octadecenoico. Adaptado de Ogawa et al. (2005). 
Tabla 2. Producción de ácido linoleico conjugado (CLA; mg/L) por diversas cepas de microorganismos. Cepa Medio ${ }^{1} \quad$ Sustrato $^{2}$ CLA total Referencia

\section{Bifidobacterium}

B. breve WC0420

B. breve WC0421

B. animalis BLC

B. animalis $\mathrm{Bb} 12$

B. bifidum LMG10645

B. breve LMG11080

B. breve LMG11613

B. bifidum NCFB795

B. breve NCFB2258

B. breve NCIMB8807

\begin{tabular}{|c|c|c|c|}
\hline MRS & LA $(0,5 g / L)$ & $\begin{array}{l}132 \\
881\end{array}$ & Raimondi et al. (2016) \\
\hline MRS/LD & $\mathrm{LA}(1 \mathrm{~g} / \mathrm{L})$ & $\begin{array}{l}7 / 48 \\
7 / 42\end{array}$ & $\begin{array}{l}\text { Rodríguez-Alcalá et al. } \\
\text { (2011) }\end{array}$ \\
\hline MRS & LA $(0,5 g / L)$ & $\begin{array}{c}207 \\
272 \\
99 \\
1\end{array}$ & Gorissen et al. (2010) \\
\hline MRS & LA $(0,5 g / L)$ & $\begin{array}{l}398 \\
128\end{array}$ & Coakley et al. (2003) \\
\hline
\end{tabular}

\section{Lactobacillus}

L. acidophilus CRL44

L. acidophilus CRL1063

L. curvatus CRL1629

L. plantarum CRL100

L. plantarum CRL1935

L. sakei CRL1470

L. acidophilus $\mathrm{Ki}$

L. plantarum ATCC8014

L. sakei LMG13558

\begin{tabular}{lccl} 
& & 112 & \\
MRS & LA $(0,3 \mathrm{~g} / \mathrm{L})$ & 364 & Terán et al. (Terán et \\
& & 84 & al., 2015) \\
& & 350 & \\
\multirow{2}{*}{ MRS } & LA $(1 \mathrm{~g} / \mathrm{L})$ & 988 & Rodríguez-Alcalá et al. \\
& & 9 & $(2011)$ \\
MRS & LA $(0,5 \mathrm{~g} / \mathrm{L})$ & 23 & Gorissen et al. (2011)
\end{tabular}

\section{Lactococcus}

Lc. lactis biovar diacetylactis CRL967

Lc. lactis biovar diacetylactis CRL1061

Lc. lactis LMG S 19870

Lc. lactis spp. cremoris CCRC12586

Lc. lactis spp. lactis

CCRC10791

$\begin{array}{lccl}\text { MRS } & \text { LA }(0,3 \mathrm{~g} / \mathrm{L}) & 50 & \begin{array}{l}\text { Terán et al. (Terán et } \\ \text { al., 2015) } \\ \text { MRS /LD }\end{array} \\ \text { LA }(1 \mathrm{~g} / \mathrm{L}) & 98 & \begin{array}{l}\text { Rodríguez-Alcalá et al. } \\ (2011)\end{array} \\ \text { LD } & \text { LA (1g/L) } & 63 & \text { Lin et al. (1999) }\end{array}$

\section{Propionibacterium}

Prop. freudenreichii spp. shermanii JS

Prop. freudenreichii spp. shermanii 9093

Prop. freudenreichii spp. freudenreichii ATCC6207 Prop. freudenreichii spp. shermanii B6022

Prop. freudenreichii spp. shermanii B6026

Prop. freudenreichii spp. shermanii B6028

$\begin{array}{lccc} & 49 & \\ \text { MRS } & 259 & \\ & & & \\ & & & \\ & & & \\ & & & \\ \text { MRS }(0,5 \mathrm{~g} / \mathrm{L}) & 160 & \\ & \text { LA }(1 \mathrm{~g} / \mathrm{L}) & 190 & \text { Das et al. (2005) }\end{array}$

1MRS: De Man, Rogosa and Sharpe; LD: leche desnatada.

2LA: ácido linoleico.

Este hecho ha dado lugar a nuevas líneas de investigación encaminadas a aumentar el contenido en CLA de los quesos mediante el uso de cultivos iniciadores o adjuntos capaces de sintetizar el CLA in vitro. Por ejemplo, el empleo de bacterias ácido lácticas autóctonas en la elaboración de queso de cabra o vaca dio lugar a unos resultados prometedores en relación con el incremento del contenido en CLA en estos quesos (Mohan et al., 2013; Taboada et al., 2015). No 
obstante, es importante indicar que sería necesario realizar más estudios al respecto ya que la información disponible es limitada.

Atendiendo a lo anteriormente descrito, el diseño de cultivos productores de CLA con aplicación en la fabricación de queso podría fomentar la diversidad de cultivos disponibles para la industria láctea así como el posible desarrollo de productos lácteos funcionales. Además, las cepas que forman parte de estos cultivos también pueden sintetizar otros compuestos, aparte del CLA, de gran interés desde el punto de vista de la salud humana. La revisión realizada acerca de estos aspectos ha sido publicada y se presenta a continuación con el mismo contenido que el artículo.

\title{
1.3. Lactic acid bacteria and bifidobacteria with potential to design natural biofunctional health-promoting dairy foods
}

\author{
Daniel M. Linares ${ }^{1,2}$, Carolina Gómez ${ }^{1}$,Erica Renes ${ }^{3}$, José María Fresno ${ }^{3}$, María Eugenia \\ Tornadijo $^{3}$, R. Paul Ross ${ }^{2}$, Catherine Stanton ${ }^{1,2}$ \\ ${ }^{1}$ Teagasc Food Research Centre, Moorepark, Ireland. ${ }^{2}$ APC Microbiome Institute, University \\ College Cork, Ireland. ${ }^{3}$ Department of Food Hygiene and Technology, University of León, \\ Spain
}

Frontiers in Microbiology, 2017, 8, 1-11

\begin{abstract}
Consumer interest in healthy lifestyle and health-promoting natural products is a major driving force for the increasing global demand of biofunctional dairy foods. A number of commercial sources sell synthetic formulations of bioactive substances for use as dietary supplements. However, the bioactive-enrichment of health-oriented foods by naturally occurring microorganisms during dairy fermentation is in increased demand. While participating in milk fermentation, lactic acid bacteria can be exploited in situ as microbial sources for naturally enriching dairy products with a broad range of bioactive components that may cover different health aspects. Several of these bioactive metabolites are industrially and economically important, as they are claimed to exert diverse healthpromoting activities on the consumer, such as anti-hypertensive, anti-inflammatory, and anti-diabetic, anti-oxidative, immune-modulatory, anti-cholesterolemic, or microbiome modulation. This review aims at discussing the potential of these health-supporting bacteria as starter or adjunct cultures for the elaboration of dairy foods with a broad spectrum of new functional properties and added value.
\end{abstract}

Keywords: lactic acid bacteria, bifidobacteria, health, bioactive, probiotic, biofunctional food.

\section{Biofunctional foods}

Today foods are not intended to only satisfy hunger and to provide necessary nutrients for humans, but also to prevent nutrition-related diseases and improve 
consumers' health (Gortzi et al., 2015; Siró et al., 2008). Increasing consumer demand and interest in obtaining additional benefits from food has stimulated functional foods to emerge on the market, with USA, Europe, and Japan being the dominant markets.

Although there is no unitary accepted definition, functional foods can be described as an ordinary food that has components or ingredients added to provide a specific health benefit, other than a purely nutritional effect. Ideally, functional food refers to an existing traditional food product that is intended to be consumed as part of a normal diet and has a demonstrated added physiological benefit (Siró et al., 2008). Therefore, it could not be in the form of pill or capsule. The concept of biofunctional foods is generally used when this desirable biological, medical, or physiological effect is exerted by microorganisms (Gobbetti et al., 2010). The health benefits of these microorganisms can be exerted either directly through the interactions of ingested live microorganisms with the host (probiotic effect), or indirectly by ingestion of the microbial metabolites synthesized during fermentation (bioactive effect) (Gobbetti et al., 2010; Joshi, 2015; Stanton et al., 2005).

\section{Probiotic foods}

Lactic acid bacteria (LAB) have been used to ferment foods for at least 4000 years (Rotar et al., 2007). Although the probiotic concept has expanded more recently, we have been unconsciously ingesting beneficial microbes with traditional fermented foods since ancient times. Fermented foods are the main carriers to deliver probiotics (Figure 3). Among them, dairy products (in particular fermented milks and yogurt) are by far the most efficient and widely used (Giraffa, 2012). Cheese is a dairy product which has a good potential for the incorporation of probiotic cultures due to its specific chemical and physical characteristics compared to fermented milks (higher $\mathrm{pH}$ value and lower titrable acidity, higher buffering capacity, greater fat content, higher nutrient availability, lower oxygen content, and denser texture). These conditions facilitate survivability of probiotic strains and tolerance to the low $\mathrm{pH}$ conditions encountered during gastric transit (Karimi et al., 2011). Utilization of probiotics has been optimized in several cheese varieties such as Cheddar, Gouda, Camembert, Cottage type, white-brined, and traditional cheeses, among others (Araujo et al., 2012; Giraffa, 2012; Martinovic et al., 2016; Oh et al., 2016). Kefir is another milk-fermented product that has health promoting bacteria (Prado et al., 2015). Other non-fermented dairy foods such as low-fat ice cream, chocolate mousse, coconut flan, or infant milk formula have also been supplemented with probiotic strains (Aragon-Alegro et al., 2007; Baglatzi et al., 2016; Corrêa et al., 2008; Davidson et al., 2000).

Probiotic microorganisms are generally LAB belonging to the species Lactobacillus acidophilus, L. gasseri, L. helveticus, L. johnsonii, L. (para) casei, L. reuteri, L. plantarum, L. rhamnosus, and L. fermentum, while members of the genus Bifidobacterium are also used, e.g., Bifidobacterium bifidum, B. longum, B. animalis, and B. breve (Castro et al., 2015; Linares et al., 2016b; Tamime et al., 2005). On the basis of the currently available literature, probiotics can balance intestinal microbiota, and thereby regulate proper intestinal function and be effective in the prevention or treatment of several gastrointestinal disorders such as infectious diarrhea, antibiotic-related diarrhea, irritable bowel syndrome or Crohn's disease (Vanderhoof and Young, 1998). Other examples of health benefits promoted by probiotics supplied via dairy products are 
inmmunomodulatory effects ( $L$. casei CRL431), reduction of serum cholesterol level ( $L$. reuteri NCIMB 30242) and antihypertensive effects (L. plantarum TENSIATM) (Aragón et al., 2014; EFSA, 2011; Jones et al., 2012).

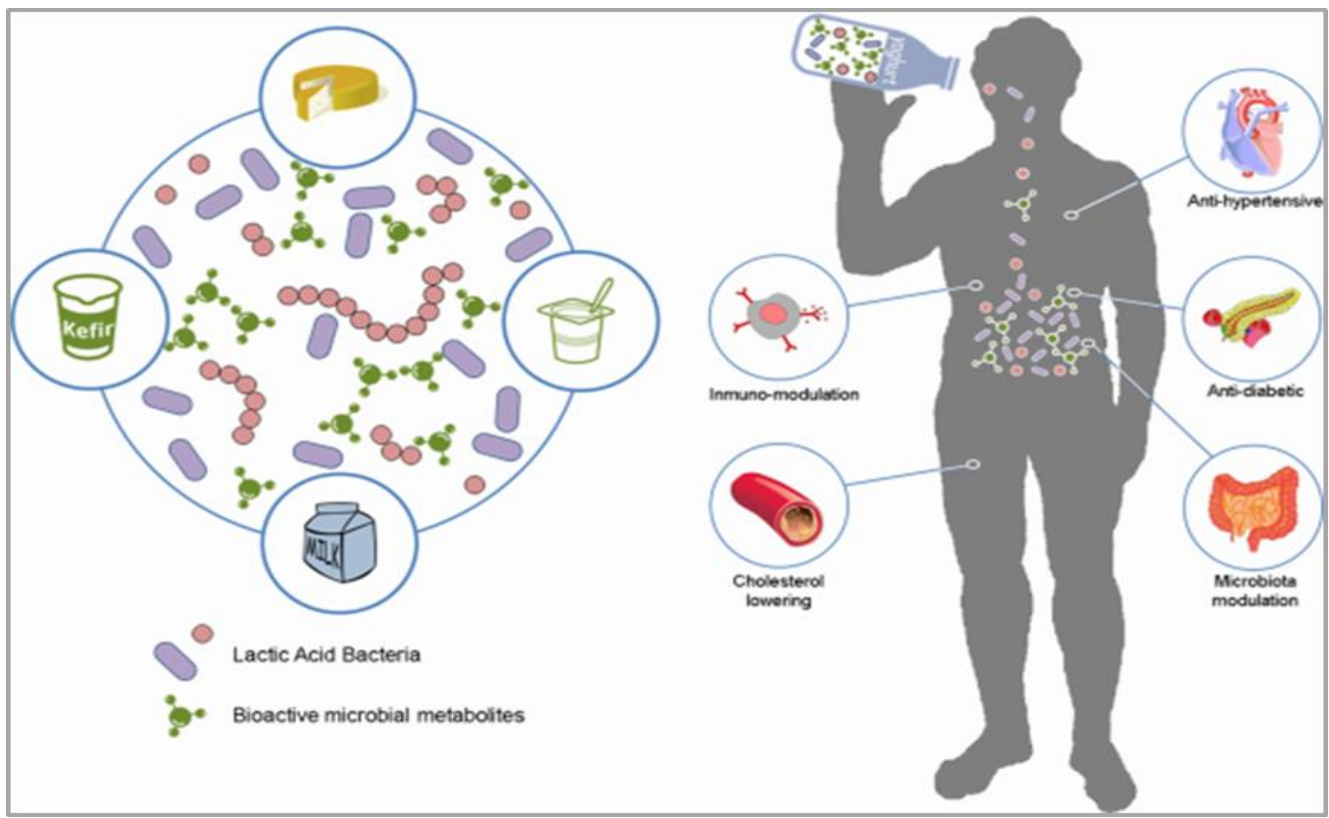

Figure 3. Beneficial effects resulting from the consumption of biofunctional fermented dairy foods. Lactic acid bacteria participating in milk fermentation in situ release and naturally enrich the fermented dairy product with a broad range of bioactive metabolites. Subsequent ingestion of this product can exert important health-promoting activities on the consumer, such as anti-hypertensive, and anti-diabetic, immune-modulatory, anti-cholesterolemic or microbiome modulation.

Probiotics are defined as live micro-organisms, which when consumed in adequate amounts confer a health benefit on the host' (FAO/WHO, 2001). However, regarding probiotic foods, some considerations are of paramount importance. Firstly, effective levels of the live probiotic in the corresponding food matrix at the time of ingestion are required. In this regard, the minimum effective dose which affects the intestinal environment and provides beneficial effects on human health is considered to be $10^{6}-10^{9}$ live microbial cells per day, although this depends on the particular strain and foodstuff (Karimi et al., 2012; Watson and Preedy, 2015; Williams, 2010). Since probiotics show beneficial health effects on the host once consumed, another precondition for a bacterial strain to be called probiotic is the ability to survive and colonize (at least transiently) the gastrointestinal tract (GIT), which is in part helped by the buffering capacity of the food matrix. In some particular cases, bacterial viability may not be strictly required. As an example, inactivated and dead L. rhamnosus GG cells can maintain immunological and health-promoting effects (Ghadimi et al., 2008; Lopez et al., 2008).

\section{Bioactive compounds derived from microbes}

Microorganisms involved in dairy fermentations can produce biologically active molecules and enzymes, giving the final food product an additional health value. Unlike 
the probiotic concept (the bacteria must be ingested alive and produce the beneficial metabolite in the body), the biofunctional concept is generally used when the healthy metabolite emerge in the food product itself during the fermentation process as a consequence of the bacterial metabolic activity. Consequently, the bacteria can act as a microbial factory to enrich foodstuff, for which bacterial viability through the GIT or during the product storage is not absolutely required (Farnworth and Champagne, 2015). The main bioactive compounds produced by LAB during dairy fermentation are vitamins, gamma-aminobutyric acid, bioactive peptides, bacteriocins, enzymes, conjugated linoleic acid, and exopolysaccharides (Table 3).

\section{Vitamins}

There are 13 vitamins that must be obtained exogenously due to the inability of humans to synthesize them; thereby they are essential nutrients in the human diet, and although in small amounts, a daily requirement is necessary to prevent deficiencies. Although most vitamins are present in a variety of foods, human vitamin deficiencies still occur in many countries, mainly because of malnutrition, not only as a result of insufficient food intake but also because of unbalanced diets (LeBlanc et al., 2002).

Although milk contains many vitamins fermentation by LAB and bifidobacteria constitute an effective way to increase vitamin levels in milk (Laiño et al., 2013). Some bacterial strains included in the genera Lactobacillus and Bifidobacterium can provide an additional source of B vitamins (thiamine, riboflavin, cobalamin, folate, and biotin) during dairy fermentation. Deficiencies in riboflavin (vitamin B2) or thiamine (vitamin B1) can lead to both liver and skin disorders and alterations in brain glucose metabolism, respectively (Russo et al., 2014). In this regard, L. casei KNE-1 has been shown to produce thiamine and riboflavin in fermented milk drinks (Drywien et al., 2015). B. infantis CCRC14633 and $B$. longum B6 strains have been reported to produce riboflavin and thiamine during soymilk fermentation (Tamime, 2006). It was recently indicated that soymilk fermented by the riboflavin-producing strain L. plantarum CRL2130 was able to prevent ariboflavinosis and experimental colitis in a murine model (Juarez del Valle et al., 2016; Levit et al., 2016). Some propionibacteria can produce cobalamin, folic acid, and biotin (Hugenholtz et al., 2002).

Folate (vitamin B9) is involved in several vital processes and its deficiency is generally linked to neural tube defects, certain forms of cancer, poor cognitive performance and coronary heart diseases. Even though vitamins are widely present in foods, the prevalence of folate deficiency -especially among women of child bearing age- is a growing concern and thereby folate fortification programs have been implemented in various countries (Divya and Nampoothiri, 2015). Rather than incorporating synthetic folate, foods can be naturally fortified with folate synthesized by LAB and bifidobacteria during manufacture of fermented foods (Lin and Young, 2000; Saubade et al., 2017). The strains Streptococcus thermophilus CRL803/CRL415 and L. bulgaricus CRL871 were reported to be suitable for the elaboration of yogurt naturally bio-enriched in this vitamin (Laiño et al., 2013). High folate concentration (up to $150 \mathrm{mg} / \mathrm{l}$ ) can be reached in yogurt as a result of the ability of $S$. thermophilus to produce this vitamin (Hugenholtz et al., 2002). 
Table 3. Some strains of lactic acid bacteria, bifidobacteria and propionibacteria with potential to biosynthesize health-promoting compounds in fermented dairy products.

Bioactive Producer strain

Thiamine/Riboflavin

Lactobacillus casei KNE-1

Bifidobacterium infantis CCRC 14633

Bifidobacterium longum B6

Lactobacillus plantarum CRL 2130

Biotin

Cobalamin

Folic acid

GABA

Bioactive peptides

Lactobacillus helveticus Calpis ${ }^{\mathrm{TM}}$

Lactobacillus bulgaricus LB340

\section{Food product}

Fermented milk

Fermented soymilk

Fermented soymilk

Fermented soymilk

Fermented milk

Kefir

Fermented milk

Soy-yogurt

Yogurt

Fermented milk

Fermented milk

Fermented milk

Fermented milk

Fermented milk

Fermented milk

Fermented milk

Fermented milk

Fermented soymilk

Yogurt

Fermented milk

Fermented milk

Fermented milk/Yogurt
Health effect

Vitamin enrichment

Vitamin enrichment

Vitamin enrichment

Vitamin enrichment

Vitamin enrichment

Vitamin enrichment

Vitamin enrichment

Vitamin enrichment

Vitamin enrichment

Vitamin enrichment

Vitamin enrichment

Vitamin enrichment

Vitamin enrichment

Vitamin enrichment

Antidiabetic, blood pressure

Antidiabetic, blood pressure

Antidiabetic, blood pressure

Antidiabetic, blood pressure

Antidiabetic, blood pressure

Anti-hypertensive

Anti-hypertensive

Anti-hypertensive
Reference

Drywlen et al. (2015)

Tamine (2006)

Tamine (2006)

Levit et al. (2016)

Patel et al. (2013)

Van Wyk et al. (2011)

Patel et al. (2013)

Gu et al. (2015)

Laiño et al. (2014)

Laiño et al. (2014)

Crittenden et al. (2003)

Crittenden et al. (2003)

Crittenden et al. (2003)

Laiño et al. (2014)

Inoue et al. (2003)

Chen et al. (2016)

Shan et al. (2015)

Park and Oh (2007)

Linares et al. (2016a)

EFSA (2008)

Dzulba and Dziuba

(2014)

Qian et al. (2011) 
Table 3 (continuation). Some strains of lactic acid bacteria, bifidobacteria and propionibacteria with potential to biosynthesize health-promoting compounds in fermented dairy products.

Bioactive

Bactericins

CLA
Streptococcus thermophilus CRL728

Bifidobacterium bifidum CRL1399

Lactococcus lactis LMG

Lactobacillus acidophilus Lac1

Lactobacillus plantarum-2

Bifidobacterium animalis $\mathrm{Bb} 12$

Lactobacillus bulgaricus LB430

\section{Exopolysaccarides}

Lactobacillus bulgaricus OLL1073R-1

Lactobacillus mucosae DPC6426

Propionibacterium freudenreichii KG15

Lactococcus lactis SMQ-461

Lactobacillus plantarum YW11

Bifidobacterium longum CCUG52486

Streptococcus thermophilus zwTM1 1

Streptococcus thermophilus FD-DVSST
Food product

Camembert cheese

Cheddar cheese

Yogurt

Cheddar cheese

Munster cheese

Cheedar cheese

Buffalo cheese

\section{Health effect}

Pathogen inhibition

Pathogen inhibition

Pathogen inhibition

Pathogen inhibition

Pathogen inhibition

Cholesterol lowering

Cholesterol lowering

Fermented buffalo milk

Cholesterol lowering

Yogurt

Yogurt

Yogurt/Cheddar cheese

Turkish cheese

Cheddar cheese

Kefir

Yogurt

Yogurt

Fermented ice-cream
Reference

Arques et al. (2015)

Ross et al. (1999)

Ahmed et al. (2010)

Arques et al. (2015)

Arques et al. (2015)

Mohan et al. (2013)

Van Niewenhove et al. (2007a)

Van Niewenhove et al. (2007b)

Sosa-Castañeda et al. (2015)

Makino et al. (2016)

Ryan et al. (2015)

Darilmaz and Gumustekin

(2012)

Dabour et al. (2005)

Wang et al. (2015)

Prassanas et al. (2013)

Han et al. (2016)

Dertli et al. (2016) 
Among bifidobacteria, B. catenulatum ATCC 27539 was shown to produce high levels of folate in vitro (D'Aimmo et al., 2012), and B. lactis CSCC5127, B. infantis CSCC5187, and B. breve CSCC5181 strains increased folate concentration during fermentation of reconstituted skim milk (Crittenden et al., 2003). Similarly, L. amylovorus CRL887 can be used for natural folate bio-enrichment of fermented milk (Laiño et al., 2014).

The deficiency of cobalamin (vitamin B12) can be common, particularly in vegetarians who avoid ingestion of animal protein and use soymilk as an alternative to dairy milk (Gu et al., 2015). Animals, plants and fungi are incapable of producing this vitamin, and hence, it is exclusively produced by microorganisms (LeBlanc et al., 2011). It has been demonstrated that cobalamin can be synthesized by some bacteria such as $L$. reuteri ZJ03, Propionibacterium freudenreichii, B. animalis $\mathrm{Bb} 12$ in soy-yogurt, kefir and fermented milk, respectively (Gu et al., 2015; Moslemi et al., 2016; Patel et al., 2013; Van Wyk et al., 2011).

Microorganisms can biosynthesize two different isoforms, the vitamin and the pseudovitamin. For example, in a recent work, the production of vitamin and pseudovitamin B12 by $P$. freudenreichii was quantified specifically and shows that at the initial phase of the fermentation both isoforms are biosynthesized at similar levels; however, by the end of the fermentation the pseudovitamin is not detected, most likely because it is converted to the vitamin form (Deptula et al., 2017). It seems crucial to differentiate between the two isoforms of this vitamin, as the transporter protein in the human GIT has very low affinity for the pseudovitamin, making it un-available to humans (Varmanen et al., 2016).

Biotin (vitamin B7) deficiency can be caused by inadequate dietary intake or some inborn genetic disorders that affect its metabolism. Subclinical deficiency can cause mild symptoms, such as hair thinning or skin rash typically on the face. Biotin can be synthesized by some LAB in dairy products, e.g., L. helveticus MTCC 5463 increased biotin content in fermented milks (Patel et al., 2013). Some propionibacteria can also produce biotin (Hugenholtz et al., 2002).

Vitamin $\mathrm{K}$ is an important promoter of bone and cardiovascular health. It has been associated with the inhibition of arterial calcification and stiffening, and the reduction of vascular risk. This vitamin is nearly non-existent in junk food; with little being consumed even in a healthy Western diet (Maresz, 2015). Its deficiency has been implicated in several clinical ailments such as intracranial hemorrhage in newborn infants and possible bone fracture resulting from osteoporosis (LeBlanc et al., 2011). Vitamin K occurs in two forms: firstly, phylloquinone (vitamin K1), which is present in green plants, and secondly, menaquinone (vitamin K2), which is produced by some intestinal bacteria (LeBlanc et al., 2011). Menaquinone can be biosynthesized by some LAB species (mainly Lactococcus lactis) commonly used in industrial fermentation of cheese, buttermilk, sour cream, cottage cheese, and kefir (Walther et al., 2013). Other LAB have been screened for the ability to produce menaquinone; these included strains from the genera Lactococcus, Bifidobacterium, Leuconostoc, and Streptococcus (Morishita et al., 1999). Although the MK forms are ubiquitous in bacteria, it should be noted that some genera such as Lactobacillus have lost the functional ability to produce them (Lechardeur et al., 2011; Walther et al., 2013). 


\section{Gamma-aminobutyric acid}

Gamma-aminobutyric acid (GABA) is the main inhibitory neurotransmitter of the central nervous system (CNS). Several important physiological functions of GABA have been characterized, such as neurotransmission, induction of hypotension, diuretic effects, antidiabetic, relaxing and tranquilizer effects (Inoue et al., 2003; Marques et al., 2016). In fact, some $\mathrm{GABA}_{\mathrm{A}}$-receptor agonist drugs (e.g., benzodiazepines) are important pharmacological agents used for clinical treatment of anxiety (Foster and Kemp, 2006).

Gamma-aminobutyric acid is biosynthesized through a-decarboxylation of glutamate, an enzymatic conversion which is catalyzed by glutamate decarboxylase (GAD) (Tajabadi et al., 2015). Several food-grade LAB have been reported to exhibit GABAproducing ability. Among them, most of the GABA-producing strains are lactobacilli ( $L$. brevis, L. paracasei, L. delbrueckii, L. buchneri, L. plantarum, L. helveticus), Streptococcus thermophilus, and Lactococcus lactis (Dhakal et al., 2012; Li and Cao, 2010). Some, Bifidobacterium spp. were also reported to produce GABA, although with lower capacity than LAB (Barrett et al., 2012; Park et al., 2005).

Some fermented dairy products enriched in GABA using GABA-producing LAB as starters have been developed. The strains $L$. casei Shirota, S. salivarius fmb5 and $L$. plantarum NDC75017 were utilized to ferment and enrich milk in GABA (Chen et al., 2016; Inoue et al., 2003; Shan et al., 2015). More recently, yogurt enriched with $2 \mathrm{mg}$ GABA/ml was produced using the strain S. thermophilus APC151 (Linares et al., 2017, 2016a). Also, fermented soya milk (using L. brevis OPY-1 as source of GABA) (Park and Oh, 2007), or cheese (Lactococcus lactis as source of GABA) (Nomura et al., 1998; Pouliot-Mathieu et al., 2013) have been produced. Thus, GABA has potential as a health-promoting bioactive component in foods (Li and Cao, 2010).

\section{Bioactive peptides}

During milk fermentation, LAB, making use of their proteolytic system can transform milk proteins into biologically active peptides. These peptides can exert a wide range of effects, such as antimicrobial, antihypertensive, antithrombotic, immunomodulatory, and antioxidative (LeBlanc et al., 2002; Nongonierma and FitzGerald, 2015). The most studied mechanism of bioactive peptides is the antihypertensive action displayed by the inhibition of the angiotensin-I-convertingenzyme (ACE; peptidyldipeptide hydrolase, EC 3.4.15.1) which regulates blood pressure (Fernández et al., 2015). ACE inhibitory peptides have been isolated from a variety of fermented dairy products including cheese, fermented milks and yogurt (Fitzgerald and Murray, 2006; Pritchard et al., 2010). The best known ACE-inhibitory biopeptides, Val-Pro-Pro (VPP) and Ile-Pro-Pro (IPP), have been identified in milk fermented by L. helveticus (Slattery et al., 2010). In addition, other dairy startercultures industrially used in the manufacture of fermented dairy products (e.g., L. helveticus, L. delbrueckii ssp. bulgaricus, L. plantarum, L. rhamnosus, L. acidophilus, Lactococcus lactis, or S. thermophilus) can generate bioactive peptides (Hafeez et al., 2014; Hajirostamloo, 2010). Other ACE-inhibitory peptides such as $\beta$-casein $\mathrm{f}(72-$ 81), Ser-Lys-Val-Tyr-Pro-Phe-Pro-Gly-Pro-Ile (SLVYPFPGPI) have been produced by $L$. delbrueckii ssp.bulgaricus LB340 in fermented milk (Qian et al., 2011).

On an industrial scale, two fermented milk products with antihypertensive claims, Calpis $^{\mathrm{TM}}$ and Evolus ${ }^{\mathrm{R}}$, have been tested extensively in rats and in clinical trials, and are 
commercialized as functional foods (Dziuba and Dziuba, 2014). Evolus ${ }^{R}$ is available in the market as a $L$. helveticus fermented milk -produced in Finland- proven to decrease the systolic blood pressure in hypertensive subjects due to the actions of $L$. helveticus bioactive peptides (EFSA, 2008). Calpis ${ }^{\mathrm{TM}}$ is defined as a milk product marketed in Japan (Calpis Co. Ltd.) with antihypertensive properties. It is prepared by fermenting skimmed milk with L. helveticus and Saccharomyces cerevisiae, which produce VPP and IPP peptides from $\beta$ casein and K-casein (Dziuba and Dziuba, 2014).

\section{Bacteriocins}

Bacteriocins are ribosomally synthesized antimicrobial peptides produced by a particular bacterium that are active against other competitor bacteria; thereby they constitute an important part of the microbial defense system (Nes et al., 2007). Such bacteriocin-producing strains may offer potential as an alternative to antibiotics, and may be useful as a means of controlling pathogen carriage, therefore being highly suitable as microbial food additives (Cotter et al., 2013) (Table 4). Bacteriocins from LAB have attracted much interest because they are frequently produced by commercially useful strains that are generally regarded as safe (GRAS) for human consumption (Nes et al., 2007). These antimicrobial molecules are among the beneficial peptides intrinsically synthesized by some LAB during milk fermentation and they have been traditionally used as naturally produced food biopreservatives. In addition, they may function in the GIT as potential natural biotherapeutic agents facilitating the competition of probiotic strains and/or inhibition of pathogens; thereby they are potential contributors to the microbiota balance and human health (Dobson et al., 2012).

Table 4. Characteristic aspects of bacteriocins compared to conventional antibiotics (Adapted from Cleveland et al. 2001).

\begin{tabular}{lll}
\hline & Bacteriocins & Antibiotics \\
Application & Foods & Clinical \\
Bioactivity spectra & Mostly narrow & Mostly broad \\
Bioactive intensity & nM- $\mu \mathrm{M}$ & $\mu \mathrm{M}-\mathrm{mM}$ \\
Biosynthesis & Ribosomal & Secondary metabolite \\
Proteolytic degradability & High & None \\
Thermostability & High & Low \\
Activity pH range & Adaptation through changes & Genetically transferable \\
Target cell resistance & in cell membrane composition & determinant that inactivates the \\
development & & Cell membrane or intercellular \\
& Generally, pore formation & targets, inhibition of cell wall \\
Mode of action & & biosynthesis \\
& None known & Present \\
\hline
\end{tabular}

Nisin is the most well-known bacteriocin used as food preservative due to its antibacterial effect against Listeria, clostridia spores and LAB associated to spoilage. Nisin has been approved as a food additive (E234) in the European Union according to Directive 95/2/EC (EC, 1995) in the following products: semolina and tapioca puddings ( $3 \mathrm{mg} / \mathrm{kg})$; ripened and processed cheese $(12.5 \mathrm{mg} / \mathrm{kg})$, clotted cream $(10 \mathrm{mg} / \mathrm{kg})$, and Mascarpone 
cheese $(10 \mathrm{mg} / \mathrm{kg})$. It is also permitted in over 40 countries world-wide including USA, Australia, South Africa, Russia, and India for use as an antimicrobial agent in a variety of food products (EFSA, 2006). Nisin-containing Camembert and semihard cheeses with prolonged shelf-life were made using Lactococcus lactis (strains CNRZ150 or TAB50, respectively) as nisin producers (Arqués et al., 2015). Apart from nisin, plantaricins are very wellknown bacteriocins. For example, plantaricin $\mathrm{C}$ is a broad spectrum bacteriocin produced by L. plantarum, isolated from ripening cheese (González et al., 1994). Plantaricins have been reported to produce an immunomodulatory effect on dendritic cells (Meijerink et al., 2010). However, bacteriocins other than nisin have so far only few and limited authorized uses in foods (Yang et al., 2015). Consequently, the use of bacteriocinproducing bacteria as starter culture for in situ biosynthesis during milk fermentation becomes an effective alternative strategy to incorporate bacteriocins in dairy foods.

Similarly, the lacticin 3147-producing strain Lactococcus lactis DPC3147 used as a protective culture in Cheddar cheese reduced numbers of Listeria monocytogenes to $<10$ $\mathrm{cfu} / \mathrm{g}$ within 5 days at $4^{\circ} \mathrm{C}$ (Chen and Hoover, 2003; Ross et al., 1999). Other bacterial species such as $L$. acidophilus can be added as an adjunct in many food fermentation processes to contribute to bacteriocin production and food preservation (Anjum et al., 2014). Other LAB strains such as L. plantarum WHE92 used as adjunct to the starter culture reduced Listeria monocytogenes, Listeria innocua, and Escherichia coli O157:H7 counts in cheese as a consequence of the production of plantaricin (Arqués et al., 2015). Using a similar concept, Danisco developed a freeze-dried culture of Pediococcus acidilactici (marketed as CHOOZIT Flav 43) for use as a bacteriocin-producer adjunct in Cheddar and semihard cheeses (Mills et al., 2011).

Studies of the direct impact of dairy foods containing bacteriocins on human health and microbiome are still limited. In vivo antimicrobial activity of nisin and lacticin 3147 has been recently demonstrated in a murine infection model. A nisin-producing Lactococcus lactis CHCC5826 modified the microbiota composition of human microbiotaassociated rats increasing bifidobacteria levels and decreasing Enterococcus/Streptococcus populations. Lacticin 3147 has the potential to be employed in the treatment of Clostridium difficile diarrhea and to eliminate the pathogen when added to an anaerobic fecal fermentation (Arqués et al., 2015).

\section{Enzymes}

Lactic acid bacteria associated to dairy fermentations possess enzymes which can be produced in situ during fermentation of dairy foods and have bioactive potential on the consumer. Examples are hydrolytic enzymes that may exert potential synergistic effects on digestion and alleviate symptoms of intestinal malabsorption (Patel et al., 2013). A wellknown example is the $\beta$-galactosidase activity, which can achieve lactose degradation and thereby improve health and reduce symptoms of lactose intolerant consumers. Yogurt and other conventional starter cultures and probiotic bacteria in fermented and unfermented milk products improve lactose digestion and alleviate symptoms of intolerance in lactose malabsorbers. These beneficial effects are due to microbial $\beta$-galactosidase (de Vrese et al., 2001). 


\section{CLA}

CLA is a polyunsaturated fatty acid (PUFA) that can be biosynthesized by LAB and bifidobacteria through bioconversion of linoleic acid (LA; cis-9, cis-12 $\mathrm{C}_{18: 2}$ ). The two isomers that have been shown to have bioactive potential are cis-9, trans-11 and trans10,cis-12. The health-promoting properties of CLA include anticarcinogenic, antiatherogenic, anti-inflammatory, and antidiabetic activity, as well as the ability to reduce body fat (Sosa-Castañeda et al., 2015). Although it is a native component of milk, the amount consumed in foods is far from that required in order to obtain desired beneficial effects. Thus, increasing the CLA content in dairy foods through milk fermentation with specific LAB offers a promising alternative. An effective way to increase CLA uptake in humans is to increase CLA levels in dairy products by using strains with high production potential (Lee et al., 2007). A number of food-grade LAB and bifidobacteria were reported to produce CLA in milk products (Sosa-Castañeda et al., 2015; Yang et al., 2015), as is the case of Lactococcus lactis LMG, L. rhamnosus C14, L. casei CRL431, L. acidophilus Lac1, L. plantarum-2, B. bifidum CRL1399 and B. animalis Bb12 (Florence et al., 2009; Van Nieuwenhove et al., 2007b). Some of these strains were also used as adjunct cultures for the manufacture of high CLA-content buffalo cheese (Van Nieuwenhove et al., 2007a). The CLA-producing starter culture of Lactococcus lactis CI4b enhanced levels of total CLA in Cheddar cheese (Mohan et al., 2013). Similarly, L. bulgaricus LB430 and S. thermophilus TA040 are suitable for production of CLA-enriched yogurt (Florence et al., 2009).

In addition, it has been shown that specific microorganisms such as L. plantarum PL60 or B. breve NCIMB702258, are able to produce CLA following dietary administration in animal models (Wall et al., 2012) and following the administration as a freeze-dried product in humans (Lee and Lee, 2009). Thus, intestinal CLA production by bacteria may contribute to enhance CLA supply in addition to the CLA provided by the producing strain in fermented milks during the manufacture (Terán et al., 2015).

\section{Exopolysaccharides}

Exopolysaccharides (EPS) are complex extracellular carbohydrate polymers that can be produced by some LAB in situ during dairy fermentations. Some of them promote selective growth of bifidobacteria, thus playing a role on the host microbiota and immune system (Fernández et al., 2015; Salazar et al., 2016). In this regard, EPS derived from yogurt fermented with $L$. delbrueckii ssp. bulgaricus OLL1073R-1 exerted immunestimulatory effects in mice (Makino et al., 2016). Yogurt, Swiss-type, and Cheddar cheeses represent suitable food matrices for the delivery of the hypocholesterolemic EPSproducer strain L. mucosae DPC 6426 (Ryan et al., 2015). Other microorganisms with potential to produce EPS in cheese are P. freudenreichii KG15/KG6, Lactococcus lactis SMQ-461 or S. thermophilus MR-1C (Dabour et al., 2005; Darilmaz and Gumustekin, 2012). Significant levels of EPS can also be produced in kefir by L. plantarum YW11 (Wang et al., 2015). Recently, EPS produced by bifidobacteria have attracted the attention due to their immune modulation capability (Hidalgo-Cantabrana et al., 2012).

Exopolysaccharides can also improve the quality, sensory and rheological properties of the final food product, which in many cases results in a reduction of the amount of chemical stabilizers required, thus favoring a more natural product. For example, strains 
of B. longum subsp. infantis CCUG 52486 and S. thermophilus were suitable to produce yogurt and fermented ice-cream with improved viscosity and texture and reduced syneresis as a consequence of their high EPS production (Dertli et al., 2016; Han et al., 2016; Prasanna et al., 2013).

\section{Regulatory aspects}

At present, the status of probiotic-based products is full of ambiguities because various regulatory agencies in different countries are defining and categorizing probiotics differently. Despite the emerging interest of consumers toward probiotics and functional foods, in Europe the regulatory framework is still not harmonized and no health claim for probiotics alone (except yogurt starters) has been approved. Paradoxically, probiotics or bioactive bacteria have been introduced into the market as dietary supplements or natural health products (capsules, tablets, and powders) (Arora and Baldi, 2015). Japan was the very first global jurisdiction for implementing a regulatory system for functional foods and nutraceuticals in 1991, and is currently acting as global market leader where probiotics are available as both foods and drugs. The government has designated Foods for Specific Health Uses (FOSHU), which classifies health claims into different subcategories (gastrointestinal health, cholesterol moderation, hypertension moderation, lipid metabolism moderation, sugar absorption moderation, mineral absorption, and bone and tooth health). In China, the State Food and Drug Administration (SFDA) has regulated all health foods including functional foods and nutraceuticals, and a well-developed market for functional foods is established (Arora and Baldi, 2015). Currently USA is regulating probiotics as a variety of products as per their intended usage and regulatory bodies are Dietary Supplement Health and Education Act (DSHEA) and Food and Drug administration (FDA). Dietary supplements are considered as 'foods' and are regulated by DSHEA and do not need FDA approval before being marketed. However, probiotics and dietary supplements containing a new dietary ingredient without a marketing history are regulated by FDA. In conclusion, a harmonized categorization of probiotics and functional foods may help to regulate these products whenever solid clinical documentation is available to support any health effects and health messages in human subjects. The appropriate level of evidence for determining a health benefit for probiotics should always be put ahead of commercial and labeling industrial interests.

\section{Challenges in industry and concluding remarks}

A goal of the dairy industry is to develop novel dairy products with increased nutritional and/or health promoting properties. Food-grade bacteria have the potential to fortify fermented dairy food products with bioactive metabolites by a natural process, thereby reducing the need for fortification with costly chemically synthesized supplements. Nowadays, a number of commercial sources have available synthetic formulations of bioactive substances for their use as a dietary supplement. The use of health-supporting bacteria for naturally enriching dairy foods with bioactives could be a suitable alternative to food fortification with chemical formulations.

The starter cultures must be carefully selected, since the ability of microbial cultures to produce bioactive metabolites is generally a strain-dependent trait and varies considerably among strains within the same species. The yield of bioactive synthesis and 
the concentration of such compound in dairy products is another critical strain-dependent factor. In this regard, the dose of bioactives ingested with the corresponding food product should remain over the minimum required to meet the human requirements and/or have the claimed therapeutic level on the consumer, according to existing clinical recommendations and studies. An open question when using co-cultures or strain combinations is their interaction in terms of nutrient availability, bacterial growth, as well as the bioactive production yield. In some cases, metabolites (i.e., vitamins etc.) produced by one of the strains could be consumed by the other strains, thus decreasing the final content in food.

Generally, the biosynthetic pathways are genetically encoded. In this regard, the increasing availability of bacterial genome sequences over the last decade has provided a major contribution to the knowledge about microbial production of bioactive molecules. However, the presence of the genes required for the biosynthesis of a particular biomolecule should not be assumed as synonym of metabolite production. Typical exceptions to the correlation genotype-phenotype occur when the genes are not active or when the metabolite is intracellularly biosynthesized and a release system is lacking. This is indeed one of the major bottlenecks during biosynthesis of some vitamins that needs to be overcome through the use of alternative strategies such as autolytic mutants and metabolic engineering (Basavanna and Prapulla, 2013).

Consideration should also be given by manufacturers to the optimum conditions for bioactive compound biosynthesis by LAB during technological processes. The content and activity of a bioactive compound in the dairy fermented foodstuffs is the result of the type of food matrix, the individual bacterial strain properties as well as the processing conditions and storage.

\section{References}

The references used in this publication are included in the reference section of the introduction (section 1.4).

\subsection{Referencias}

Ahmed, Z., Wang, Y., Cheng, Q., Imran, M., 2010. Lactobacillus acidophilus bacteriocin, from production to their application: an overview. African J. Biotechnol. 9, 28432850 .

Andrade, J.C., Ascençao, K., Gullón, P., Henriques, S.M.S., Pinto, J.M.S., Rocha-Santos, T.A.P., Freitas, A.C., Gomes, A.M., 2012. Production of conjugated linoleic acid by food-grade bacteria: a review. Int. J. Dairy Technol. 65, 467-481.

Anjum, N., Maqsood, S., Masud, T., Ahmad, A., Sohail, A., Momin, A., 2014. Lactobacillus acidophilus: characterization of the species and application in food production. Crit. Rev. Food Sci. Nutr. 54, 1241-1251.

Aragon-Alegro, L.C., Alarcon-Alegro, J.H., Cardarelli, H.R., Chiu, M.C., Saad, S.M., 2007. Potentially probiotic and synbiotic chocolate mousse. LWT-Food Sci. Technol. 40, 669-675.

Aragón, F., Carino, S., Perdigón, G., de Moreno de LeBlanc, A., 2014. The administration of milk fermented by the probiotic Lactobacillus casei CRL 431 exerts an 
immunomodulatory effect against a breast tumour in a mouse model. Immunobiology 219, 457-64.

Araujo, E.A., dos Santos Pires, A.C., Pinto, M.S., Jan, G., Carvalho, A.F., 2012. Probiotics in dairy fermented products, in: Rigobelo, E. (Ed.), Probiotics. InTech, Rijeka, pp. $129-148$.

Arora, M., Baldi, A., 2015. Regulatory categories of probiotics across the globe: a review representing existing and recommended categorization. Indian J. Med. Microbiol. 33, 2.

Arqués, J.L., Rodríguez, E., Langa, S., Landete, J.M., Medina, M., 2015. Antimicrobial activity of lactic acid bacteria in dairy products and gut: effect on pathogens. Biomed Res. Int. 2015, 1-9.

Baglatzi, L., Gavrili, S., Stamouli, K., Zachaki, S., Favre, L., Pecquet, S., Benyacoub, J., Costalos, C., 2016. Effect of infant formula containing a low dose of the probiotic Bifidobacterium lactis CNCM I-3446 on immune and gut functions in C-section delivered babies: a pilot study. Clin. Med. Insights Pediatr. 10, 11-19.

Balthazar, C.F., Pimentel, T.C., Ferrão, L.L., Almada, C.N., Santillo, A., Albenzio, M., Mollakhalili, N., Mortazavian, A.M., Nascimento, J.S., Silva, M.C., Freitas, M.Q., Sant'Ana, A.S., Granato, D., Cruz, A.G., 2017. Sheep milk: physicochemical characteristics and relevance for functional food development. Compr. Rev. Food Sci. Food Saf. 16, 247-262.

Barrett, E., Ross, R.P., O’Toole, P.W., Fitzgerald, G.F., Stanton, C., 2012. Y-Aminobutyric acid production by culturable bacteria from the human intestine. J. Appl. Microbiol. $113,411-417$.

Basavanna, G., Prapulla, S.G., 2013. Evaluation of functional aspects of Lactobacillus fermentum CFR 2195 isolated from breast fed healthy infants' fecal matter. J. Food Sci. Technol. 50, 360-366.

Bigliardi, B., Galati, F., 2013. Innovation trends in the food industry: the case of functional foods. Trends Food Sci. Technol. 31, 118-129.

Botelho, A. P., Santos-Zago, L. F., Reis, S. M. P. M., \& Oliveira, A. C. D. (2005). A suplementação com ácido linoléico conjugado reduziu a gordura corporal em ratos Wistar. Rev.Nutr. 18, 561-565.

Cabiddu, A., Decandia, M., Addis, M., Piredda, G., Pirisi, A., Molle, G., 2005. Managing Mediterranean pastures in order to enhance the level of beneficial fatty acids in sheep milk. Small Rumin. Res. 59, 169-180.

Castro, J.M., Tornadijo, M.E., Fresno, J.M., Sandoval, H., 2015. Biocheese: a food probiotic carrier. Biomed Res. Int. 2015, 1-11.

Chen, H., Hoover, D.G., 2003. Bacteriocins and their food applications. Compr. Rev. Food Sci. Food Saf. 2, 82-100.

Chen, L., Zhao, H., Zhang, C., Lu, Y., Zhu, X., Lu, Z., 2016. Gamma-aminobutyric acidrich yogurt fermented by Streptococcus salivarius subsp. thermophiles fmb5 appears to have anti-diabetic effect on streptozotocin-induced diabetic mice. J. Funct. Foods 20, 267-275.

Chilliard, Y., Glasser, F., Ferlay, A., Bernard, L., Rouel, J., Doreau, M., 2007. Diet, rumen biohydrogenation and nutritional quality of cow and goat milk fat. Eur. J. Lipid Sci. Technol. 109, 828-855. 
Churruca, I., Fernández-Quintela, A., Portillo, M.P., 2009. Conjugated linoleic acid isomers: differences in metabolism and biological effects. BioFactors 35, 105-111.

Cleveland, J., Montville, T.J., Nes, I.F., Chikindas, M.L., 2001. Bacteriocins: safe, natural antimicrobials for food preservation. Int. J. Food Microbiol. 71, 1-20.

Coakley, M., Ross, R.P., Nordgren, M., Fitzgerald, G., Devery, R., Stanton, C., 2003. Conjugated linoleic acid biosynthesis by human-derived Bifidobacterium species. J. Appl. Microbiol. 94, 138-145.

Corrêa, S.B.M., Castro, I.A., Saad, S.M.I., 2008. Probiotic potential and sensory properties of coconut flan supplemented with Lactobacillus paracasei and Bifidobacterium lactis. Int. J. Food Sci. Technol. 43, 1560-1568.

Cossignani, L., Giua, L., Urbani, E., Simonetti, M.S., Blasi, F., 2014. Fatty acid composition and CLA content in goat milk and cheese samples from Umbrian market. Eur. Food Res. Technol. 239, 905-911.

Cotter, P.D., Ross, R.P., Hill, C., 2013. Bacteriocins - a viable alternative to antibiotics? Nat. Rev. Microbiol. 11, 95-105.

Crittenden, R.G., Martinez, N.R., Playne, M.J., 2003. Synthesis and utilisation of folate by yoghurt starter cultures and probiotic bacteria. Int. J. Food Microbiol. 80, 217-222.

D’Aimmo, M.R., Mattarelli, P., Biavati, B., Carlsson, N.G., Andlid, T., 2012. The potential of bifidobacteria as a source of natural folate. J. Appl. Microbiol. 112, 975-984.

Dabour, N., Kheadr, E.E., Fliss, I., LaPointe, G., 2005. Impact of ropy and capsular exopolysaccharide-producing strains of Lactococcus lactis subsp. cremoris on reduced-fat Cheddar cheese production and whey composition. Int. Dairy J. 15, 459471.

Darilmaz, D.O., Gumustekin, Y., 2012. Research on some factors influencing acid and exopolysaccharide produced by dairy Propionibacterium strains isolated from traditional homemade Turkish cheeses. J. Food Prot. 75, 918-926.

Das, S., Holland, R., Crow, V.L., Bennett, R.J., Manderson, G.J., 2005. Effect of yeast and bacterial adjuncts on the CLA content and flavour of a washed-curd, dry-salted cheese. Int. Dairy J. 15, 807-815.

Davidson, R.H., Duncan, S.E., Hackney, C.R., Eigel, W.N., Boling, J.W., 2000. Probiotic culture survival and implications in fermented frozen yogurt characteristics. J. Dairy Sci. 83, 666-673.

De La Fuente, L.F., Barbosa, E., Carriedo, J.A., Gonzalo, C., Arenas, R., Fresno, J.M., San Primitivo, F., 2009. Factors influencing variation of fatty acid content in ovine milk. J. Dairy Sci. 92, 3791-3799.

de Vrese, M., Stegelmann, A., Richter, B., Fenselau, S., Laue, C., Schrezenmeir, J., 2001. Probiotics: compensation for lactase insufficiency. Am. J. Cinical Nutr. 73, 421S429S.

Deptula, P., Chamlagain, B., Edelmann, M., Sangsuwan, P., Nyman, T.A., Savijoki, K., Piironen, V., Varmanen, P., 2017. Food-like growth conditions support production of active citamin B12 by Propionibacterium freudenreichii 2067 without DMBI, the lower ligand base, or cobalt supplementation. Front. Microbiol. 8, 368.

Dertli, E., Toker, O.S., Durak, M.Z., Yilmaz, M.T., Tatlısu, N.B., Sagdic, O., Cankurt, H., 2016. Development of a fermented ice-cream as influenced by in situ exopolysaccharide production: rheological, molecular, microstructural and sensory 
characterization. Carbohydr. Polym. 136, 427-40.

Dhakal, R., Bajpai, V.K., Baek, K.H., 2012. Production of GABA (gamma- aminobutyric acid) by microorganisms: a review. Brazilian J. Microbiol. 43, 1230-1241.

Diana, M., Quílez, J., Rafecas, M., 2014. Gamma-aminobutyric acid as a bioactive compound in foods: a review. J. Funct. Foods 10, 407-420.

Dilzer, A., Park, Y., 2012. Implication of conjugated linoleic acid (CLA) in human health. Crit. Rev. Food Sci. Nutr. 52, 488-513.

Divya, J.B., Nampoothiri, K.M., 2015. Encapsulated Lactococcus lactis with enhanced gastrointestinal survival for the development of folate enriched functional foods. Bioresour. Technol. 188, 226-230.

Dobson, A., Cotter, P.D., Ross, R.P., Hill, C., 2012. Bacteriocin production: a probiotic trait? Appl. Environ. Microbiol. 78, 1-6.

Drywien, M., Frackiewicz, J., Górnicka, M., Gadek, J., Jałosiñska, M., 2015. Effect of probiotic and storage time of thiamine and riboflavin content in the milk drinks fermented by Lactobacillus casei KNE-1. Rocz. Państwowego Zakładu Hig. 66, 373377.

Dziuba, B., Dziuba, M., 2014. Milk proteins-derived bioactive peptides in dairy products: molecular, biological and methodological aspects. ACTA Sci. Pol. Technol. Aliment. $13,5-25$.

EFSA, 2011. Scientific Opinion on the substantiation of a health claim related to "Lactobacillus plantarum TENSIATM in the semihard Edam-type 'heart cheese' of Harmony ${ }^{\mathrm{TM}}$ " and maintenance of normal blood pressure pursuant to article 13(5) of regulation (EC) No 1924/20061. EFSA J. 9, 1981.

EFSA, 2008. Evolus and reduce arterial stiffness - Scientific substantiation of a health claim related to Lactobacillus helveticus fermented Evolus ${ }^{\mathrm{R}}$ low-fat milk products and reduction of arterial stiffness pursuant to article 14 of the regulation (EC) No 1924/2006 . EFSA J. 824, 1-12.

EFSA, 2006. Opinion of the scientific panel on food additives, flavourings, processing aids and materials in contact with food on a request from the commission related to the use of nisin (E 234) as a food additive: question number EFSA-Q-2005-2031. EFSA J. 314, 1-16.

El-Salam, M.H.A., El-Shibiny, S., 2014. Conjugated linoleic acid and vaccenic acid contents in cheeses: an overview from the literature. J. Food Compos. Anal. 33, 117126.

Elwood, P.C., Pickering, J.E., Givens, D.I., Gallacher, J.E., 2010. The consumption of milk and dairy foods and the incidence of vascular disease and diabetes: an overview of the evidence. Lipids 45, 925-939.

FAO/WHO, 2001. Report of the joint FAO/WHO expert consultation on evaluation of health and nutritional properties of probiotics in food including powder milk with live lactic acid bacteria. Food and Agriculture Organization of the United Nations, Rome.

FAO, 2015. FAOSTAT, Statistics division. Food and Agriculture Organization of the United Nations. http:// faostat.fao.org/

Farnworth, E.R., Champagne, C.P., 2015. Production of probiotic cultures and their incorporation into foods, in: Watson, R.R., Preedy, V.R. (Eds.), Probiotics, Prebiotics, and Synbiotics: Bioactive Foods in Health Promotion. Elsiever Academic Press, 
Amsterdam, pp. 303-318.

Fernández, M., Hudson, J.A., Korpela, R., de los Reyes-Gavilán, C.G., 2015. Impact on human health of microorganisms present in fermented dairy products: an overview. Biomed Res. Int. 2015, 1-13.

Fitzgerald, R.J., Murray, B.A., 2006. Bioactive peptides and lactic fermentations. Int. J. Dairy Technol. 59, 118-125.

Florence, A.C.R., da Silva, R., do Espírito Santo, A.P., Gioielli, L.A., Tamime, A.Y., de Oliveira, M.N., 2009. Increased CLA content in organic milk fermented by bifidobacteria or yoghurt cultures. Dairy Sci. Technol. 89, 541-553.

Foster, A.C., Kemp, J.A., 2006. Glutamate- and GABA-based CNS therapeutics. Curr. Opin. Pharmacol. 6, 7-17.

Ghadimi, D., Fölster-Holst, R., de Vrese, M., Winkler, P., Heller, K.J., Schrezenmeir, J., 2008. Effects of probiotic bacteria and their genomic DNA on TH1/TH2-cytokine production by peripheral blood mononuclear cells (PBMCs) of healthy and allergic subjects. Immunobiology 213, 677-692.

Giraffa, G., 2012. Selection and design of lactic acid bacteria probiotic cultures. Eng. Life Sci. 12, 391-398.

Gobbetti, M., Cagno, R. d, De Angelis, M., 2010. Functional microorganisms for functional food quality. Crit. Rev. Food Sci. Nutr. 50, 716-727.

Gómez-Cortés, P., 2010. Efecto de la suplementación de la dieta ovina con distintas fuentes lipídicas sobre el perfil de ácidos grasos de la leche. Tesis Doctoral. Departamento de Química Física I. Facultad de Ciencias Químicas. Universidad Complutense de Madrid.

González, B., Arca, P., Mayo, B., Suárez, J.E., 1994. Detection, purification, and partial characterization of plantaricin $\mathrm{C}$, a bacteriocin produced by a Lactobacillus plantarum strain of dairy origin. Appl. Environ. Microbiol. 60, 2158-63.

Gorissen, L., Raes, K., Weckx, S., Dannenberger, D., Leroy, F., De Vuyst, L., De Smet, S., 2010. Production of conjugated linoleic acid and conjugated linolenic acid isomers by Bifidobacterium species. Appl. Microbiol. Biotechnol. 87, 2257-2266.

Gorissen, L., Weckx, S., Vlaeminck, B., Raes, K., De Vuyst, L., De Smet, S., Leroy, F., 2011. Linoleate isomerase activity occurs in lactic acid bacteria strains and is affected by $\mathrm{pH}$ and temperature. J. Appl. Microbiol. 111, 593-606.

Gortzi, O., Tsakali, E., Chatzilazarou, A., Galidi, A., 2015. E-food science project: biofunctional foods, in: Proceedings of the $2^{\text {nd }}$ International Conference on Food and Biosystems Engineering. Mykonos.

Gu, Q., Zhang, C., Song, D., Li, P., Zhu, X., 2015. Enhancing vitamin B12 content in soyyogurt by Lactobacillus reuteri. Int. J. Food Microbiol. 206, 56-59.

Hafeez, Z., Cakir-Kiefer, C., Roux, E., Perrin, C., Miclo, L., Dary-Mourot, A., 2014. Strategies of producing bioactive peptides from milk proteins to functionalize fermented milk products. Food Res. Int. 63, 71-80.

Hajirostamloo, B., 2010. Bioactive component in milk and dairy product. Int. Scicence Index Agric. Biosyntesis 4, 870-874.

Han, X., Yang, Z., Jing, X., Yu, P., Zhang, Y., Yi, H., Zhang, L., 2016. Improvement of the texture of yogurt by use of exopolysaccharide producing lactic acid bacteria. Biomed Res. Int. 2016, 1-6. 
Hennessy, A.A., Barrett, E., Paul Ross, R., Fitzgerald, G.F., Devery, R., Stanton, C., 2012. The production of conjugated a-linolenic, $\gamma$-linolenic and stearidonic acids by strains of bifidobacteria and propionibacteria. Lipids 47, 313-327.

Hervás, G., Luna, P., Mantecón, A.R., Castañares, N., de la Fuente, M.A., Juárez, M., Frutos, P., 2008. Effect of diet supplementation with sunflower oil on milk production, fatty acid profile and ruminal fermentation in lactating dairy ewes. J. Dairy Res. 75, 399.

Hidalgo-Cantabrana, C., López, P., Gueimonde, M., de los Reyes-Gavilán, C.G., Suárez, A., Margolles, A., Ruas-Madiedo, P., 2012. Immune modulation capability of exopolysaccharides synthesised by lactic acid bacteria and bifidobacteria. Probiotics Antimicrob. Proteins 4, 227-237.

Hugenholtz, J., Hunik, J., Santos, H., Smid, E., 2002. Nutraceutical production by propionibacteria. Lait 82, 103-112.

Inoue, K., Shirai, T., Ochiai, H., Kasao, M., Hayakawa, K., Kimura, M., Sansawa, H., 2003. Blood-pressure-lowering effect of a novel fermented milk containing $\gamma$-aminobutyric acid (GABA) in mild hypertensives. Eur. J. Clin. Nutr. 57, 490-495.

Ip, C., Singh, M., Thompson, H.J., Scimeca, J.A., 1994. Conjugated linoleic acid suppresses mammary carcinogenesis and proliferative activity of the mammary gland in the rat. Cancer Res. 54, 1212-5.

Iwata, T., Kamegai, T., Yamauchi-Sato, Y., Ogawa, A., Kasai, M., Aoyama, T., Kondo, K., 2007. Safety of dietary conjugated linoleic acid (CLA) in a 12-weeks trial in healthy overweight Japanese male volunteers. J. Oleo Sci. 56, 517-25.

Jenkins, T.C., Wallace, R.J., Moate, P.J., Mosley, E.E., 2008. Recent advances in biohydrogenation of unsaturated fatty acids within the rumen microbial ecosystem. J. Anim. Sci. 86, 397-412.

Jones, M.L., Martoni, C.J., Parent, M., Prakash, S., 2012. Cholesterol-lowering efficacy of a microencapsulated bile salt hydrolase-active Lactobacillus reuteri NCIMB 30242 yoghurt formulation in hypercholesterolaemic adults. Br. J. Nutr. 107, 1505-1513.

Joshi, V.K., 2015. Fermented foods of South Asia. Fermented foods and beverages series. CRC Press, Boca Ratón, Florida.

Juarez del Valle, M., Laiño, J.E., de Moreno de LeBlanc, A., Savoy de Giori, G., LeBlanc, J.G., 2016. Soyamilk fermented with riboflavin-producing Lactobacillus plantarum CRL 2130 reverts and prevents ariboflavinosis in murine models. Br. J. Nutr. 116, 1229-1235.

Kalač, P., Samková, E., 2010. The effects of feeding various forages on fatty acid composition of bovine milk fat: a review. Czech J. Anim. Sci. 55, 521-537.

Karimi, R., Mortazavian, A., Cruz, A., Mohammad Mortazavian, A., Gomes Da Cruz, A., Karimi, R., Mortazavian, A.M., Da Cruz, A.G., 2011. Viability of probiotic microorganisms in cheese during production and storage: a review. Dairy Sci. Technol. 91, 283-308.

Karimi, R., Mortazavian, A.M., Amiri-Rigi, A., 2012. Selective enumeration of probiotic microorganisms in cheese. Food Microbiol. 29, 1-9.

Kloss, R., Linscheid J., Johnson, A., Lawson, B., E dwards, K., Linder, T., 2005. Effects of conjugated linoleic acid supplementation on blood lipids and adiposity of rats fed diets rich saturated versus unsaturated fat. Pharmacol Res. 51, 503-507. 
Koba, K., Yanagita, T., 2014. Health benefits of conjugated linoleic acid (CLA). Obes. Res. Clin. Pract. 8, 525-532.

Kraft, J., Collomb, M., Möckel, P., Sieber, R., Jahreis, G., 2003. Differences in CLA isomer distribution of cow's milk lipids. Lipids 38, 657-64.

Laiño, J.E., Juarez del Valle, M., Savoy de Giori, G., LeBlanc, J.G.J., 2014. Applicability of a Lactobacillus amylovorus strain as co-culture for natural folate bio-enrichment of fermented milk. Int. J. Food Microbiol. 191, 10-16.

Laiño, J.E., Juarez del Valle, M., Savoy de Giori, G., LeBlanc, J.G.J., 2013. Development of a high folate concentration yogurt naturally bio-enriched using selected lactic acid bacteria. LWT - Food Sci. Technol. 54, 1-5.

LeBlanc, J.G., Laiño, J.E., del Valle, M.J., Vannini, V., van Sinderen, D., Taranto, M.P., de Valdez, G.F., de Giori, G.S., Sesma, F., 2011. B-Group vitamin production by lactic acid bacteria - current knowledge and potential applications. J. Appl. Microbiol. 111, 1297-1309.

LeBlanc, J.G., Matar, C., Valdéz, J.C., LeBlanc, J., Perdigon, G., 2002. Immunomodulating effects of peptidic fractions issued from milk fermented with Lactobacillus helveticus. J. Dairy Sci. 85, 2733-2742.

Lechardeur, D., Cesselin, B., Fernandez, A., Lamberet, G., Garrigues, C., Pedersen, M., Gaudu, P., Gruss, A., 2011. Using heme as an energy boost for lactic acid bacteria. Curr. Opin. Biotechnol. 22, 143-149.

Lee, K., Lee, Y., 2009. Production of c9,t11- and t10,c12-conjugated linoleic acids in humans by Lactobacillus rhamnosus PL60. J. Microbiol. Biotechnol. 19, 1617-9.

Lee, K., Paek, K., Lee, H.Y., Park, J.H., Lee, Y., 2007. Antiobesity effect of trans-10,cis-12conjugated linoleic acid-producing Lactobacillus plantarum PL62 on diet-induced obese mice. J. Appl. Microbiol. 103, 1140-1146.

Lehnen, T.E., da Silva, M.R., Camacho, A., Marcadenti, A., Lehnen, A.M., 2015. A review on effects of conjugated linoleic fatty acid (CLA) upon body composition and energetic metabolism. J. Int. Soc. Sports Nutr. 12, 36.

Levit, R., de Giori, G.S., de Moreno de LeBlanc, A., LeBlanc, J.G., 2016. Evaluation of the effect of soymilk fermented by a riboflavin-producing Lactobacillus plantarum strain in a murine model of colitis. Benef. Microbes 8, 65-72.

Li, H., Cao, Y., 2010. Lactic acid bacterial cell factories for gamma-aminobutyric acid. Amino Acids 39, 1107-1116.

Lin, M.Y., Young, C.M., 2000. Folate levels in cultures of lactic acid bacteria. Int. Dairy J. 10, 409-413.

Lin, T.Y., Lin, C.W., Lee, C.H., 1999. Conjugated linoleic acid concentration as affected by lactic cultures and added linoleic acid. Food Chem. 67, 1-5.

Linares, D.M., Arboleya, S., Ross, R.P., Stanton, C., 2017. Complete genome sequence of the gamma-aminobutyric acid-producing strain Streptococcus thermophilus APC151. Genome Announc. 5, 205-217.

Linares, D.M., O'Callaghan, T.F., O’Connor, P--.M., Ross, R.P., Stanton, C., 2016a. Streptococcus thermophilus APC151 strain is suitable for the manufacture of naturally GABA-enriched bioactive yogurt. Front. Microbiol. 7, 1876.

Linares, D.M., Ross, P., Stanton, C., 2016b. Beneficial microbes: the pharmacy in the gut. Bioengineered 7, 11-20. 
Lock, A.L., Bauman, D.E., 2004. Modifying milk fat composition of dairy cows to enhance fatty acids beneficial to human health. Lipids 39, 1197-206.

Lopez, M., Li, N., Kataria, J., Russell, M., Neu, J., 2008. Live and ultraviolet-inactivated Lactobacillus Rhamnosus GG decrease flagellin-induced interleukin-8 production in caco-2 cells. J. Nutr. 138, 2264-2268.

Makino, S., Sato, A., Goto, A., Nakamura, M., Ogawa, M., Chiba, Y., Hemmi, J., Kano, H., Takeda, K., Okumura, K., Asami, Y., 2016. Enhanced natural killer cell activation by exopolysaccharides derived from yogurt fermented with Lactobacillus delbrueckii ssp. bulgaricus OLL1073R-1. J. Dairy Sci. 99, 915-923.

MAPAMA, 2016. Ministerio de Agricultura y Pesca, Alimentación y Medio Ambiente de España.http://www.mapama.gob.es/es/estadistica/temas/publicaciones/anuariode-estadistica/

Maresz, K., 2015. Proper calcium use: vitamin K2 as a promoter of bone and cardiovascular health. Integr. Med. 14, 34-9.

Marques, T.M., Patterson, E., Wall, R., O'Sullivan, O., Fitzgerald, G.F., Cotter, P.D., Dinan, T.G., Cryan, J.F., Ross, R.P., Stanton, C., 2016. Influence of GABA and GABAproducing Lactobacillus brevis DPC 6108 on the development of diabetes in a streptozotocin rat model. Benef. Microbes 7, 409-420.

Martinovic, A., Brede, M.E., Vegarud, G.E., Østlie, H.M., Narvhus, J., Skeie, S.B., 2016. Survival of lactic acid and propionibacteria in low- and full-fat Dutch-type cheese during human digestion ex vivo. Lett. Appl. Microbiol. 62, 404-410.

Martins, S. V, Madeira, A., Lopes, P.A., Pires, V.R.M., Alfaia, C.M., Prates, J.A.M., Moura, T., Soveral, G., 2015. Adipocyte membrane glycerol permeability is involved in the anti-adipogenic effect of conjugated linoleic acid. Biochem. Biophys. Res. Commun. 458, 356-61.

Meijerink, M., van Hemert, S., Taverne, N., Wels, M., de Vos, P., Bron, P.A., Savelkoul, H.F., van Bilsen, J., Kleerebezem, M., Wells, J.M., 2010. Identification of genetic loci in Lactobacillus plantarum that modulate the immune response of dendritic cells using comparative genome hybridization. PLoS One 5e:10632.

Mills, S., Stanton, C., Hill, C., Ross, R.P., 2011. New developments and applications of bacteriocins and peptides in foods. Annu. Rev. Food Sci. Technol. 2, 299-329.

Mohan, M.S., Anand, S., Kalscheur, K.F., Hassan, A.N., Hippen, A.R., 2013. Starter cultures and cattle feed manipulation enhance conjugated linoleic acid concentrations in Cheddar cheese. J. Dairy Sci. 96, 2081-2094.

Morishita, T., Tamura, N., Makino, T., Kudo, S., 1999. Production of menaquinones by lactic acid bacteria. J. Dairy Sci. 82, 1897-1903.

Moslemi, M., Mazaheri Nezhad Fard, R., Hosseini, S.M., Homayouni-Rad, A., Mortazavian, A.M., 2016. Incorporation of propionibacteria in fermented milks as a probiotic. Crit. Rev. Food Sci. Nutr. 56, 1290-1312.

Nes, I.F., Yoon, S.S., Diep, D.B., 2007. Ribosomally synthesized antimicrobial peptides (bacteriocins) in lactic acid bacteria: a review. Food Sci. Biotechnol. 21, 465-99.

Nieuwenhove, V.C.P., Oliszewski, R., González, S.N., Pérez Chaia, A.B., 2007. Conjugated linoleic acid conversion by dairy bacteria cultured in MRS broth and buffalo milk. Lett. Appl. Microbiol. 44, 467-474.

Nomura, M., Kimoto, H., Someya, Y., Furukawa, S., Suzuki, I., 1998. Production of $\gamma$ - 
aminobutyric acid by cheese starters during cheese ripening. J. Dairy Sci. 81, 14861491.

Nongonierma, A.B., FitzGerald, R.J., 2015. The scientific evidence for the role of milk protein-derived bioactive peptides in humans: a review. J. Funct. Foods 17, 640-656.

Ogawa, J., Kishino, S., Ando, A., Sugimoto, S., Mihara, K., Shimizu, S., 2005. Production of conjugated fatty acids by lactic acid bacteria. J. Biosci. Bioeng. 100, 355-364.

Oh, N.S., Joung, J.Y., Lee, J.Y., Kim, S.H., Kim, Y., 2016. Characterization of the microbial diversity and chemical composition of Gouda cheese made by potential probiotic strains as an adjunct starter culture. J. Agric. Food Chem. 64, 7357-7366.

Pariza, M.W., 2009. Bioactivities and potential mechanisms of action for conjugated fatty acids. Food Sci. Biotechnol. 18, 586-593.

Pariza, M.W., 2004. Perspective on the safety and effectiveness of conjugated linoleic acid. Am. J. Clin. Nutr. 79, 1132-1136.

Park, K.B., Ji, G.E., Park, M.S., Oh, S.H., 2005. Expression of rice glutamate decarboxylase in Bifidobacterium Longum enhances $y$-aminobutyric acid production. Biotechnol. Lett. 27, 1681-1684.

Park, K.B., Oh, S.H., 2007. Production of yogurt with enhanced levels of gammaaminobutyric acid and valuable nutrients using lactic acid bacteria and germinated soybean extract. Bioresour. Technol. 98, 1675-1679.

Park, Y.W., Juárez, M., Ramos, M., Haenlein, G.F.W., 2007. Physico-chemical characteristics of goat and sheep milk. Small Rumin. Res. 68, 88-113.

Parodi, P.W., 1977. Conjugated octadecadienoic acids of milk fat. J. Dairy Sci. 60, 15501553.

Patel, A., Shah, N., Prajapati, J.B., 2013. Biosynthesis of vitamins and enzymes in fermented foods by lactic acid bacteria and related genera - A promising approach, Croat. J. Food Sci. and Technol. 5, 85-91.

Pellattiero, E., Cecchinato, A., Tagliapietra, F., Schiavon, S., Bittante, G., 2015. Determination by $\mathrm{GC} \times \mathrm{GC}$ of fatty acid and conjugated linoleic acid (CLA) isomer profiles in six selected tissues of lambs fed on pasture or on indoor diets with and without rumen-protected CLA. J. Agric. Food Chem. 63, 963-974.

Pouliot-Mathieu, K., Gardner-Fortier, C., Lemieux, S., St-Gelais, D., Champagne, C.P., Vuillemard, J.C., 2013. Effect of cheese containing gamma-aminobutyric acidproducing lactic acid bacteria on blood pressure in men. PharmaNutrition 1, 141148.

Prado, M.R., Blandón, L.M., Vandenberghe, L.P.S., Rodrigues, C., Castro, G.R., ThomazSoccol, V., Soccol, C.R., 2015. Milk kefir: composition, microbial cultures, biological activities, and related products. Front. Microbiol. 6:1177.

Prasanna, P.H.P., Grandison, A.S., Charalampopoulos, D., 2013. Microbiological, chemical and rheological properties of low fat set yoghurt produced with exopolysaccharide (EPS) producing Bifidobacterium strains. Food Res. Int. 51, 15-22.

Pritchard, S.R., Phillips, M., Kailasapathy, K., 2010. Identification of bioactive peptides in commercial Cheddar cheese. Food Res. Int. 43, 1545-1548.

Qian, B., Xing, M., Cui, L., Deng, Y., Xu, Y., Huang, M., Zhang, S., 2011. Antioxidant, antihypertensive, and immunomodulatory activities of peptide fractions from fermented skim milk with Lactobacillus delbrueckii ssp. bulgaricus LB340. J. Dairy 
Res. 78, 72-79.

Raimondi, S., Amaretti, A., Leonardi, A., Quartieri, A., Gozzoli, C., Rossi, M., 2016. Conjugated linoleic acid production by bifidobacteria: screening, kinetic, and composition. Biomed Res. Int. 2016, 1-8.

Rodríguez-Alcalá, L.M., Braga, T., Malcata, X.F., Gomes, A., Fontecha, J., 2011. Quantitative and qualitative determination of CLA produced by Bifidobacterium and lactic acid bacteria by combining spectrophotometric and Ag+-HPLC techniques. Food Chem. 125, 1373-1378.

Rodríguez-Castañedas, J.L., 2012. Ácido linoleico conjugado en leche de oveja y productos derivados: presencia e influencia del proceso tecnológico. Tesis Doctoral. Departamento de Química Analítica, Nutrición y Bromatología. Universidad de Salamanca.

Rodríguez-Castañedas, J.L., Peña-Egido, M.J., García-Marino, M., García-Moreno, C., 2011. Quantitative determination of conjugated linoleic acid isomers by silver ion HPLC in ewe milk fat. J. Food Compos. Anal. 24, 1004-1008.

Ross, R.P., Galvin, M., McAuliffe, O., Morgan, S.M., Ryan, M.P., Twomey, D.P., Meaney, W.P., Hill, C., 1999. Developing applications for lactococcal bacteriocins. Antonie Van Leeuwenhoek 76, 337-346.

Rotar, M.A., Semeniuc, C., Apostu, S., Suharoschi, R., Mureşan, C., Modoran, C., Laslo, C., Guş, C., Culea, M., 2007. Researches concerning microbiological evolution of lactic acid bacteria to yoghurt storage during shelf-life. J. Agroaliment. Process. Technol. Commun. 13, 135-138.

Ruiz, J.P.A., Alonzo, M.W., Pertiñez, M.D., 2016. Conjugated linoleic acid of dairy foods is affected by cows' feeding system and processing of milk. Sci. Agric. 73, 103-108.

Russo, P., Capozzi, V., Arena, M.P., Spadaccino, G., Dueñas, M.T., López, P., Fiocco, D., Spano, G., 2014. Riboflavin-overproducing strains of Lactobacillus fermentum for riboflavin-enriched bread. Appl. Microbiol. Biotechnol. 98, 3691-3700.

Ryan, P.M., Guinane, C.M., London, L.E.E., Kelleher, P.R., Fitzgerald, G.F., Caplice, N.M., Ross, R.P., Stanton, C., 2015. Genome sequence of the heteropolysaccharideproducing strain Lactobacillus mucosae DPC 6426. Genome Announc. 3, 1350-14.

Salazar, N., Gueimonde, M., de los Reyes-Gavilán, C.G., Ruas-Madiedo, P., 2016. Exopolysaccharides produced by lactic acid bacteria and bifidobacteria as fermentable substrates by the intestinal microbiota. Crit. Rev. Food Sci. Nutr. 56, 1440-1453.

Saubade, F., Hemery, Y.M., Guyot, J.P., Humblot, C., 2017. Lactic acid fermentation as a tool for increasing the folate content of foods. Crit. Rev. Food Sci. Nutr. 57, 38943910 .

Sehat, N., Yurawecz, M.P., Roach, J.A.G., Mossoba, M.M., Kramer, J.K.G., Ku, Y., 1998. Silver-ion high-performance liquid chromatographic separation and identification of conjugated linoleic acid isomers. Lipids 33, 217-221.

Shan, Y., Man, C.X., Han, X., Li, L., Guo, Y., Deng, Y., Li, T., Zhang, L.W., Jiang, Y.J., 2015. Evaluation of improved $\gamma$-aminobutyric acid production in yogurt using Lactobacillus plantarum NDC75017. J. Dairy Sci. 98, 2138-2149.

Signorelli, F., Contarini, G., Annicchiarico, G., Napolitano, F., Orrù, L., Catillo, G., Haenlein, G.F.W., Moioli, B., 2008. Breed differences in sheep milk fatty acid profiles: 
opportunities for sustainable use of animal genetic resources. Small Rumin. Res. 78, 24-31.

Siró, I., Kápolna, E., Kápolna, B., Lugasi, A., 2008. Functional food. Product development, marketing and consumer acceptance: a review. Appetite 51, 456-467.

Slattery, L., O'Callaghan, J., Fitzgerald, G.F., Beresford, T., Ross, R.P., 2010. Invited review: Lactobacillus helveticus - A thermophilic dairy starter related to gut bacteria. J. Dairy Sci. 93, 4435-4454.

Song, K., Song, I.B., Gu, H.J., Na, J.Y., Kim, S., Yang, H.S., Lee, S.C., Huh, C.K., Kwon, J., 2016. Anti-diabetic effect of fermented milk containing conjugated linoleic acid on type II diabetes mellitus. Korean J. Food Sci. Anim. Resour. 36, 170-177.

Sosa-Castañeda, J., Hernández-Mendoza, A., Astiazarán-García, H., Garcia, H.S., EstradaMontoya, M.C., González-Córdova, A.F., Vallejo-Cordoba, B., 2015. Screening of Lactobacillus strains for their ability to produce conjugated linoleic acid in milk and to adhere to the intestinal tract. J. Dairy Sci. 98, 6651-6659.

Stanton, C., Murphy, J., McGrath, E., Devery, R., 2003. Animal feeding strategies for conjugated linoleic acid enrichment of milk, in: Sebedio, J.L., Christie, W.W., Adlof, R. (Eds.), Advances in Conjugated Linoleic Acid Research. AOCS Press, Champaign IL (USA), pp. 123-145.

Stanton, C., Ross, R.P., Fitzgerald, G.F., Sinderen, D. V, 2005. Fermented functional foods based on probiotics and their biogenic metabolites. Curr. Opin. Biotechnol. 16, 198203.

Taboada, N., Van Nieuwenhove, C., Alzogaray, S.L., Medina, R., 2015. Influence of autochthonous cultures on fatty acid composition, esterase activity and sensory profile of Argentinean goat cheeses. J. Food Compos. Anal. 40, 86-94.

Tajabadi, N., Baradaran, A., Ebrahimpour, A., Rahim, R.A., Bakar, F.A., Manap, M.Y.A., Mohammed, A.S., Saari, N., 2015. Overexpression and optimization of glutamate decarboxylase in Lactobacillus plantarum Taj-Apis362 for high gamma-aminobutyric acid production. Microb. Biotechnol. 8, 623-632.

Tamime, A. (Ed.), 2006. Fermented milks. Blackwell Publishing Ltd, Oxford.

Tamime, A.Y., Saarela, M., Korslund-Sødergaard, A., Mistry, V. V, Shah, N.P., 2005. Production and maintenance of viability of probiotic micro-organisms in dairy products, in: Tamime, A.Y. (Ed.), Probiotic Dairy Products. Blackwell Publishing Ltd, Oxford, pp. 39-72.

Tanaka, K., 2005. Occurrence of conjugated linoleic acid in ruminant products and its physiological functions. Anim. Sci. J. 76, 291-303.

Terán, V., Pizarro, P.L., Zacarías, M.F., Vinderola, G., Medina, R., Van Nieuwenhove, C., 2015. Production of conjugated dienoic and trienoic fatty acids by lactic acid bacteria and bifidobacteria. J. Funct. Foods 19, 417-425.

Tsiplakou, E., Kominakis, A., Zervas, G., 2008. The interaction between breed and diet on CLA and fatty acids content of milk fat of four sheep breeds kept indoors or at grass. Small Rumin. Res. 74, 179-187.

Tsiplakou, E., Mountzouris, K.C., Zervas, G., 2006. Concentration of conjugated linoleic acid in grazing sheep and goat milk fat. Livest. Sci. 103, 74-84.

Van Nieuwenhove, C.P., Oliszewski, R., González, S.N., Pérez Chaia, A.B., 2007a. Influence of bacteria used as adjunct culture and sunflower oil addition on conjugated linoleic 
acid content in buffalo cheese. Food Res. Int. 40, 559-564.

Van Nieuwenhove, C.P., Oliszewski, R., González, S.N., Pérez Chaia, A.B., 2007b. Conjugated linoleic acid conversion by dairy bacteria cultured in MRS broth and buffalo milk. Lett. Appl. Microbiol. 44, 467-474.

van Wijlen, J.R.P., Colombani, P.C., 2010. Grass-based ruminant production methods and human bioconversion of vaccenic acid with estimations of maximal dietary intake of conjugated linoleic acids. Int. Dairy J. 20, 433-448.

Van Wyk, J., Witthuhn, R.C., Britz, T.J., 2011. Optimisation of vitamin B12 and folate production by Propionibacterium freudenreichii strains in kefir. Int. Dairy J. 21, 6974.

Vanderhoof, J.A., Young, R.J., 1998. Use of probiotics in childhood gastrointestinal disorders. J. Pediatr. Gastroenterol. Nutr. 27, 323-332.

Varmanen, P., Deptula, P., Chamlagain, B., Piironen, V., 2016. Letter to the editor on 'Enhancing vitamin B12 content in soy-yogurt by Lactobacillus reuteri, IJFM. 206:5659.' Int. J. Food Microbiol. 228, 33.

Wall, R., Marques, T.M., O’Sullivan, O., Ross, R.P., Shanahan, F., Quigley, E.M., Dinan, T.G., Kiely, B., Fitzgerald, G.F., Cotter, P.D., Fouhy, F., Stanton, C., 2012. Contrasting effects of Bifidobacterium breve NCIMB 702258 and Bifidobacterium breve DPC 6330 on the composition of murine brain fatty acids and gut microbiota. Am. J. Clin. Nutr. 95, 1278-1287.

Walther, B., Karl, J.P., Booth, S.L., Boyaval, P., 2013. Menaquinones, bacteria, and the food supply: the relevance of dairy and fermented food products to vitamin $\mathrm{K}$ requirements. Adv. Nutr. 4, 463-473.

Wang, J., Zhao, X., Tian, Z., Yang, Y., Yang, Z., 2015. Characterization of an exopolysaccharide produced by Lactobacillus plantarum YW11 isolated from Tibet kefir. Carbohydr. Polym. 125, 16-25.

Watkins, B.A., Li, Y., 2003. CLA in functional food: enrichment of animal products, in: Sebedio, J.L., Christie, W.W., Adolf, R. (Eds.), Advances in Conjugated Linoleic Acid Research. AOCS Press, Champaign IL (USA), pp. 174-188.

Watson, R.R., Preedy, V.R. (Eds.), 2015. Probiotics, prebiotics and symbiotics: Bioactive foods in health promotion, 1st ed. Elsiever Academic Press, Amsterdam.

Williams, N.T., 2010. Probiotics. Am. J. Heal. Pharm. 67, 449-58.

Yang, B., Chen, H., Stanton, C., Ross, R.P., Zhang, H., Chen, Y.Q., Chen, W., 2015. Review of the roles of conjugated linoleic acid in health and disease. J. Funct. Foods 15, 314-325. 



\section{JUSTIFICACIÓN Y OBJETIVOS}





\section{JUSTIFICACIÓN Y OBJETIVOS}

Los ácidos grasos saturados del queso han dado lugar a una percepción negativa de este alimento por parte de los consumidores. Sin embargo, se ha observado que el queso puede aportar compuestos bioactivos con efectos beneficiosos sobre la salud humana como el CLA. Actualmente se observan cambios en los hábitos alimentarios del consumidor que se traducen en una demanda creciente de alimentos que mejoren la salud. En relación con esto, el estudio de los factores que puedan generar un incremento de la concentración de CLA en el queso podría tener gran interés en el posible desarrollo de alimentos funcionales.

La leche y productos lácteos, entre ellos el queso, son las principales fuentes de CLA en la alimentación. En este sentido, se ha observado que la grasa de la leche de oveja presenta una mayor concentración de CLA que la de vaca o la de cabra. En esta última década, el CLA ha despertado un gran interés por sus propiedades anticarcinogénicas, antitrombogénicas, antiarterioescleróticas y por su efecto en la reducción de la grasa corporal. Un aspecto a resaltar es que se ha detectado que la concentración de CLA en el queso es la misma que la de la leche empleada como materia prima. Por este motivo, la mejora del perfil lipídico de los productos lácteos ha de comenzar desde la producción de la materia prima, es decir, de la leche. Distintos estudios han puesto de manifiesto la gran importancia de la dieta de los animales rumiantes en el contenido en CLA presente en la grasa láctea. La mayoría de estos trabajos se han llevado a cabo en rebaños de ovino experimentales. Sin embargo, la información sobre el efecto de la alimentación y de otros factores asociados al sistema de manejo empleado en granjas comerciales de ovino sobre el perfil de ácidos grasos de la leche de tanque de oveja es muy escasa. En consecuencia, el control de los factores que conlleven a la obtención de leche de oveja con un mejor perfil nutricional podría permitir a los ganaderos e industria láctea obtener una materia prima con mayor valor añadido sin que suponga un incremento significativo en sus costes de producción.

Por otro lado, la concentración de CLA en queso también puede ser incrementada durante el proceso de elaboración del mismo mediante el empleo de bacterias ácido lácticas con capacidad para producir CLA a partir del ácido linoleico presente en la leche. Desde hace mucho tiempo, las bacterias ácido lácticas juegan un papel esencial en el proceso de fermentación que tiene lugar en la elaboración de algunos alimentos, en especial del queso y han sido generalmente reconocidas como seguras (Generally Recognized As Safe; GRAS) en la elaboración de productos fermentados. En este propósito, las bacterias ácido lácticas contribuyen a la acidificación de la leche y durante la maduración de los quesos ejercen actividades proteolíticas y lipolíticas que contribuyen a la textura, aroma y sabor del queso. Como consecuencia de esto, la selección de cepas de bacterias lácticas para el diseño de nuevos cultivos iniciadores que presenten buenas propiedades tecnológicas y capacidad para sintetizar compuestos beneficiosos para la salud puede dar lugar a la mejora del proceso de fermentación así como a un producto final de mejor calidad. 
En la actualidad, la pasterización de la leche para elaborar queso permite asegurar la calidad microbiológica de los mismos. Sin embargo, este hecho hace necesario el empleo de cultivos iniciadores y adjuntos comerciales, que si bien generan un mayor grado de control sobre el proceso de fermentación y estandarización del producto final, también dan lugar a quesos con menor personalidad, los cuales son percibidos por el consumidor como "aburridos". Así mismo, algunas características metabólicas importantes en las bacterias lácticas están codificadas por plásmidos, existiendo el riesgo de que se pierdan debido a la adaptación a la matriz alimentaria. En la industria quesera, este hecho ha conducido a una pérdida de la singularidad de cada variedad de queso. Actualmente, para poder solucionar este problema, se están aislando cepas autóctonas de quesos tradicionales que puedan permitir la producción de queso sin que se pierdan las características sensoriales que los caracterizan. Por consiguiente, el diseño de cultivos compuestos por bacterias lácticas autóctonas con capacidad para sintetizar CLA y con buenas propiedades tecnológicas para elaborar queso permitiría obtener un producto con propiedades sensoriales atractivas y con una composición nutricional mejorada.

Durante el proceso de maduración del queso, como se ha mencionado anteriormente, las bacterias ácido lácticas juegan un papel importante en la proteólisis debido a que estas bacterias contienen proteinasas y peptidasas que dan lugar a la producción de aminoácidos libres, los cuales pueden servir de sustrato en reacciones catabólicas secundarias, también por acción de las bacterias ácido lácticas, generándose compuestos tales como el GABA o la ornitina con efectos fisiológicos positivos sobre la salud humana. Sin embargo, también hay que tener en cuenta que ciertas bacterias ácido lácticas están implicadas en reacciones de descarboxilación que dan lugar a la síntesis de compuestos tóxicos como las aminas biógenas. En consecuencia, el consumo de alimentos con elevada concentración de aminas biógenas puede provocar efectos toxicológicos y estos problemas pueden ser más importantes en consumidores cuyo sistema de detoxificación es menos eficiente por causas genéticas o por tratamientos farmacológicos. Por este motivo, cuando se diseñan nuevos cultivos para elaborar queso es necesario asegurar que las bacterias que forman parte de estos cultivos no generan altas concentraciones de aminas biógenas en el producto final.

Los cultivos son uno de los principales responsables de las características físicoquímicas que presenta cada variedad de queso ya que como se ha mencionado anteriormente juegan un papel muy importante tanto en la acidificación de la leche como durante la maduración de los quesos. Como resultado, esta actividad microbiana afecta directa e indirectamente a la microestructura del queso y en consecuencia, también a las características sensoriales del mismo.

En base a lo anteriormente descrito, el objetivo general de esta Tesis Doctoral fue estudiar la repercusión que tuvo la selección de leche de tanque con alto contenido en CLA así como el empleo de cultivos iniciadores y adjuntos capaces de sintetizar CLA y otros compuestos con efectos beneficiosos sobre la salud humana como el GABA sobre el perfil nutricional del queso de oveja. 
Para lograr tal fin, los objetivos específicos planteados en el desarrollo de esta Tesis fueron los siguientes:

1. Investigar el efecto de la alimentación, de la etapa de lactación, del mes de muestreo y del rebaño en el perfil de ácidos grasos, con especial énfasis en el CLA, de la leche de tanque de granjas de ovino comerciales.

2. Identificar y estudiar la capacidad de diferentes cepas de bacterias ácido lácticas aisladas de quesos artesanales para producir CLA y GABA.

3. Diseñar varios cultivos iniciadores y/o adjuntos constituidos por combinaciones de dichas cepas de bacterias ácido lácticas con capacidad para sintetizar CLA.

4. Elaborar quesos a partir de leche de oveja con alto contenido en CLA y empleando los diferentes cultivos diseñados con el fin de conocer la evolución de los parámetros físico-químicos y de los principales grupos microbianos de los quesos a lo largo de la maduración.

5. Estudiar el efecto de los cultivos diseñados y del tiempo de maduración sobre el perfil de ácidos grasos del queso de oveja.

6. Estudiar el efecto de los diferentes cultivos diseñados sobre el perfil de aminoácidos libres, con especial énfasis en el GABA y la ornitina, sobre la microestructura y sobre el contenido en aminas biógenas de los quesos de oveja durante la maduración de los mismos.

7. Evaluar las características sensoriales de los quesos mediante análisis instrumental y empleando un panel de catadores. 


CAPÍtulO 1

\title{
Effect of feeding regimen on the fatty acid profile of sheep bulk tank milk
}

\author{
Erica Renes ${ }^{1}$, Fernando De la Fuente ${ }^{2}$, Domingo Fernández ${ }^{1}$, María Eugenia Tornadijo ${ }^{1}$ \\ and José Maria Fresno ${ }^{1}$ \\ ${ }^{1}$ Department of Food Hygiene and Technology, University of León, Spain. ${ }^{2}$ Department of \\ Animal Production, University of León, Spain. \\ International Journal of Dairy Technology, 2018 (Accepted; doi: 10.1111/1471-0307.12553)
}

\section{Abstract}

The quality of dairy products is affected by the fatty acid (FA) profile of the milk. The aim of this study was to determine whether the feeding regimen and lactation stage of sheep produced a healthier FA profile of milk. The study was carried out on 30 commercial farms, and the feeding regimens studied were different grazing allowances $(50 \%, \mathrm{G} 1 ; 25 \%$, G2; $0 \%, \mathrm{G} 3$ ). The variance explained by the lactation stage for the FAs was below $4.18 \%$. The milk from the grazing allowance G1 (50\% grazing time per day plus alfalfa silage and barley grains) showed a higher conjugated linoleic acid (1.16\%) proportion, followed by the grazing allowances G2 $(0.90 \%)$ and G3 $(0.79 \%)$, which showed that grazing improved the nutritional quality of milk fat. 



\section{INTRODUCTION}

Fatty acids (FAs) in milk and cheese are receiving increasing research attention due to the relationship between consumption of saturated FAs and the risk of developing coronary heart disease (Elwood et al. 2010). However, the fat in milk and dairy products also contains compounds that are beneficial for consumer health, such as vaccenic acid, oleic acid, conjugated linoleic acid (CLA) and omega-3 polyunsaturated FAs (PUFAs) (Zlatanos et al. 2002; Field et al. 2009; Sofi et al. 2010; Sales-Campos et al. 2013; Yang et al. 2016). Milk and dairy products are our main natural dietary source of CLA, and it has been observed that the fat in sheep milk has a higher CLA content than that of cow or goat milk (Park et al. 2007). Most of the production of sheep milk is used to manufacture cheese. Nudda et al. (2005) detected that the CLA content from unprocessed raw milk can be recovered in cheese. Therefore, the production of cheese from sheep milk with increased mono- and polyunsaturated FAs content, especially CLA and omega-3, warrants for high nutritional properties of such dairy products (Zlatanos et al. 2002; Sofi et al. 2010; Koba and Yanagita 2014).

Over the past decade, numerous studies have been conducted on ruminant diet as a means to improve the milk FA profile because ruminant feeding is considered to be the major factor affecting the quality of sheep milk fat and, therefore, of sheep cheese (Stanton et al. 2003; Hervás et al. 2008; Shingfield et al. 2008; Kalac and Samková 2010). Tsiplakaou et al. (2008) stated that increasing the supply of grass and thus omega-3 PUFAs in the livestock diet represents one of the strategies for enhancing the content of these FAs and CLA in sheep milk. Cabiddu et al. (2005) have shown that season is another factor possibly affecting the FA profile of sheep milk because the phenological stage of the botanical species that are part of the pastures differs depending on the time of year. These authors observed that flocks grazing on spring pastures (rich in a-linolenic acid) produced milk with higher CLA and omega-3 content compared to the milk obtained from the same flocks when grazed on summer pastures. Some authors have stated that the effect of other factors such as flock, lactation stage or breed on the milk FA profile is not significant compared to the feeding regimen or season effects (Tsiplakou et al. 2008; De la Fuente et al. 2009). However, little information is available about the effects of the lactation stage and the feeding regimen on sheep commercial farms. This study could thus provide the dairy industry, including farmers and advisors, new knowledge about usual farming practices that could lead to an improvement in sheep milk nutritional quality.

The aim of this study was therefore to investigate the effects of the feeding regimen and lactation stage on the FA profile of sheep bulk tank milk from commercial farms.

\section{MATERIALS AND METHODS}

\section{Experimental design}

This study was conducted on the sheep bulk tank milk records of 30 commercial farms between April and July 2016. It took place in the prefecture of Zamora in Castilla and León and more specifically in the regions of Villalpando and Villamayor de Campos. This overall region covers a total of $153 \mathrm{~km}^{2}$, and it is characterized by its cereal fields' predominance at an altitude between 685 and $695 \mathrm{~m}$ above sea level and for its warm- 
summer Mediterranean climate (Kottek et al. 2006). In this geographical area, the parity of sheep takes place during winter and spring, and three feeding regimens coexist.

The farms studied in this work were grouped according to their feeding regimens, and the sheep breeds studied were: Assaf, Awassi and Castellana. The first group (G1; $\mathrm{n}=10$ ) consisted of sheep flocks with a regimen of $50 \%$ grazing time per day plus alfalfa silage (200 g of dry matter/animal and day) and barley grains (250 g of dry matter/animal and day) addition during the experimental period. In the second group (G2;n=10) of flocks, the feeding regimen was $25 \%$ grazing time per day with alfalfa silage $(600 \mathrm{~g}$ of dry matter/animal and day) and hay (600 g of dry matter/animal and day) addition. The third group $(\mathrm{G} 3 ; \mathrm{n}=10)$ consisted of sheep flocks managed under an intensive system $(0 \%$ grazing time per day) during the experimental period, fed with alfalfa silage (600 g of dry matter/animal and day), hay (500 g of dry matter/animal and day) and commercial concentrate mix $(2 \mathrm{~kg}$ of dry matter/animal and day; granulated feed, corn grain, granulated dehydrated alfalfa, cotton seed, beet pulp, treacle).

The lactation stages considered were as follows: 20-60 days postpartum (initial), 60110 days postpartum (middle) and 110-160 days postpartum (final). Births were grouped in each farm. Therefore, most of the sheep in each farm were in the same lactation stage.

\section{Population and milk sampling}

The farms were located in Villalpando (41 $\left.51^{\prime} 53^{\prime \prime} \mathrm{N}, 5^{\circ} 24^{\prime} 47^{\prime \prime} \mathrm{W}\right)$ and Villamayor de

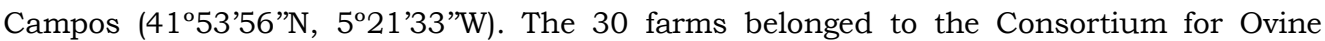
Promotion (Zamora, Castilla and León, Spain), which is the largest cooperative in the sheep milk sector in Spain. The size of each flock was between 275 and 975 sheep. All the sheep were milked twice a day during the milking period.

Bulk tank milk samples $(100 \mathrm{~mL})$ were taken on the same day in April ( $\mathrm{n}=30)$, May $(n=30)$, June $(n=30)$ and July $(n=30)$. Sampling was carried out during these months as they represent the most important grazing period. A total of 120 bulk tank sheep milk samples were analysed. They were preserved with bronopol $(0.05 \%)$ and stored at $4^{\circ} \mathrm{C}$ until laboratory analysis within $96 \mathrm{~h}$ of collection (De La Fuente et al. 2009). Analytical determination of 32 FAs per sample was carried out in the Department of Food Hygiene and Technology at University of León (León, Spain).

\section{Physicochemical and microbiological composition of milk}

All milk samples were analysed for total solids, fat, protein, lactose and somatic cells by Milkoscan FT2(Foss Electric, Hillerod, Denmark), and for aerobic mesophilic bacteria counts by Bactoscan FC (Foss Electric).

\section{Quantification of FAs in sheep milk}

Lipids were extracted from the milk samples using the method described by Bligh and Dyer (1959), and FA methyl esters were prepared by base-catalysed methanolysis of glycerides $\left(\mathrm{NaOCH}_{3}\right)$, following the method described by Aldai et al. (2005).

A Hewlett Packard 6890 Series Gases Chromatography System (Hewlett Packard, Wilmington, DE, USA) equipped with a Hewlett Packard 7683 Series Injector (Hewlett Packard) and a Hewlett Packard 5973 Mass Selective Detector (Hewlett Packard) was used. FAs separation was carried out using a Tekno TR-CN 100 capillary column $(0.2 \mu \mathrm{m}$, 
particle size, $60 \mathrm{~m} \times 0.25 \mathrm{~mm}$ I.D.; Teknokroma, Barcelona, Spain). Helium was used as a carrier gas at a flow rate of $1 \mathrm{~mL} / \mathrm{min}$. The injection and detector temperatures were $230^{\circ} \mathrm{C}$. The temperature program was as follows: the initial temperature was held at $50^{\circ} \mathrm{C}$ for $1 \mathrm{~min}$ after injection, then programmed to increase at $15^{\circ} \mathrm{C} / \mathrm{min}$ to $200^{\circ} \mathrm{C}$, held there for $3 \mathrm{~min}$, and then programmed to increase at $2^{\circ} \mathrm{C} / \mathrm{min}$ to $200^{\circ} \mathrm{C}$, and held there for 5 min. Samples $(1 \mu \mathrm{L})$ were injected by split injection (split ratio 10:1).

Each peak was identified and quantified using a 37-component FAME mix standard (Supelco, Sigma-Adrich Co., Saint Louis, USA). CLA, in particular, was identified using a 50:50 mixture from individual standard solutions of the two CLA isomers of interest in this study (cis-9,trans-11 $\mathrm{C}_{18: 2}$; trans-10,cis-12 $\mathrm{C}_{18: 2}$ ) (Larodan Fine Chemicals AB, Malmö, Sweden). A nonanoic ( $\left.\mathrm{C}_{9: 0}\right)$ FAME (Sigma-Adrich Co.) was added to the methylated milk fat samples prior to GC analysis and was used as an internal standard for chromatographic analysis. The individual FA proportion in milk samples was expressed as $\mathrm{g} / 100 \mathrm{~g}$ of total FAs (g/100 g total FAs).

\section{Studied FAs}

Although 32 FAs were studied initially, statistical analysis was primarily restricted to the 12 most important ones $\left(\mathrm{C}_{8: 0}, \mathrm{C}_{10: 0}, \mathrm{C}_{12: 0}, \mathrm{C}_{14: 0}, \mathrm{C}_{16: 0}, \mathrm{C}_{18: 0}, \mathrm{C}_{18: 1}, \mathrm{C}_{18: 2}\right.$ cis-9,cis-12, $\mathrm{C}_{18: 3}$ cis-9, cis-12, cis-15, C $18: 2$ cis-9, trans- 11 (CLA), C $18: 2$ trans-10, cis-12 (CLA), C $20: 4$ cis-5, cis8,cis-11,cis-14) from a quantitative and/or biofunctional point of view (De La Fuente et al. 2009), and to seven FA groups and five FA indexes, which were all treated as dependent variables. The FA groups based on saturation level and chain length were as follows: the sum of short-chain saturated $\mathrm{FAs}\left(\mathrm{C}_{4}\right.$ to $\left.\mathrm{C}_{10}, \mathrm{SCFA}\right)$; the sum of medium-chain saturated FAs $\left(\mathrm{C}_{11}\right.$ to $\left.\mathrm{C}_{15}, \mathrm{MCFA}\right)$; and the sum of long-chain saturated $\mathrm{FAs}\left(\mathrm{C}_{16}\right.$ to $\left.\mathrm{C}_{24}, \mathrm{LCFA}\right)$. The four remaining groups were as follows: the sum of monounsaturated FAs (MUFA); the sum of PUFA; the sum of omega- 6 FAs and the sum of omega- 3 FAs. The five indexes considered were as follows: the unsaturated FAs (UFA)/saturated FAs (SFA) ratio; the omega-6/omega-3 ratio; the $\mathrm{C}_{18: 2}$ cis- 9 , trans- $11 / \mathrm{C}_{18: 2}$ cis-9, cis-12 ratio; the atherogenicity index (AI) defined as $\left[\left(\mathrm{C}_{12: 0}+4 \times \mathrm{C}_{14: 0}+\mathrm{C}_{16: 0}\right) /(\Sigma\right.$ unsaturated FA)] (Ulbricht and Southgate 1991); and the desaturase index (DI) calculated as $\mathrm{C}_{14: 1}$ cis-9/ $\mathrm{C}_{14: 0}$ ratio (Renna et al. 2012).

\section{Statistical analysis}

Statistical analysis was carried out using the MIXED procedure in SAS (SAS Institute, Inc., Cary, NC), following the mathematical model below:

$$
\mathrm{Y}_{\mathrm{ijklm}}=\mu+\mathrm{R}_{\mathrm{i}}+\mathrm{F}_{\mathrm{j}(\mathrm{i})}+\mathrm{M}_{\mathrm{k}}+\mathrm{L}_{\mathrm{l}}+(\mathrm{R} \times \mathrm{M})_{\mathrm{ik}}+\mathrm{e}_{\mathrm{ijk} \mathrm{k}} \text {, }
$$

where $Y_{i j k l m}$ refers to the 29 dependent variables; namely six physicochemical and microbiological parameters, 12 FAs, seven groups of FAs and five FA indexes, and $\mu$ is the overall mean. The $R_{i}$ factor refers to the fixed effect of feeding regimen; there were three levels: G1, G2, G3. The $F_{j(i)}$ factor is the fixed effect of flock within feeding regimen; there were 30 levels. $M_{k}$ refers to the fixed effect of sampling month; there were four levels: April, May, June and July. $L_{l}$ is the fixed effect of lactation stage; there were three levels: initial, middle and final. $(R \times M)_{i k}$ refers to the effect of interaction between feeding regimen and sampling month, and $e_{i j k l m}$ is the residual effect. Other interactions were not statically significant $(P>0.05)$ and consequently removed from the statistical model. 
The MIXED procedure was used to study the statistical significance of the variation factors, and the least squares means and contrasts of differences between means were estimated. Following the indicated model, but considering all factors as random, the VARCOMP procedure was used to estimate the percentage of variance explained by each fixed effect (sampling month, flock, lactation stage and feeding regimen) for the 12 FAs, seven groups of FAs and five FA indexes.

Additionally, in order to analyse the flock effect, hierarchical clustering was performed using the Ward method (Euclidean distance squared) using SPSS v.21 (SPSS, Chicago, IL, USA).

\section{RESULTS AND DISCUSSION}

\section{Physicochemical and microbiological composition of the milk}

The physicochemical and microbiological composition of milk determines its quality and suitability for use in the manufacture of dairy products. The physicochemical and microbiological parameters studied in the bulk tank milk samples are shown in Table 1.

The average concentrations of fat, protein, lactose and total solids in all the milk samples analysed were within the range described by Mayer and Fieschter (2012). Significant differences were observed $(P \leq 0.001)$ in the fat and protein concentrations in milk from the three groups studied. The G1 grazing group presented the highest average concentration of fat $(73.96 \mathrm{~g} / \mathrm{kg}$ milk), followed by the G2 $(68.23 \mathrm{~g} / \mathrm{kg}$ milk) and the G3 $(66.02 \mathrm{~g} / \mathrm{kg}$ milk). Similarly, the G1 grazing group presented the highest average concentration of protein $(57.05 \mathrm{~g} / \mathrm{kg}$ milk), followed by the G2 $(51.52 \mathrm{~g} / \mathrm{kg}$ milk) and G3 $(51.83 \mathrm{~g} / \mathrm{kg}$ milk), with no significant differences between the latter $(P>0.05)$. It has been observed that in sheep, management systems focusing primarily on milk yield lead to lower concentrations of fat and protein in milk than in less intensive systems (Morand-Fehr et al. 2007).

Table 1. Least squares means and standard errors for the physicochemical and microbiological parameters by feeding regimen in sheep bulk tank milk.

\begin{tabular}{|c|c|c|c|c|c|}
\hline \multirow{2}{*}{ Parameterx } & \multicolumn{3}{|c|}{ Feeding regimen+ } & \multirow{2}{*}{ SE } & \multirow{2}{*}{ P-value } \\
\hline & G1 & G2 & G3 & & \\
\hline Fat & $73.96^{a}$ & $68.23^{b}$ & $66.02^{b}$ & 0.07 & $* * *$ \\
\hline Protein & $57.05^{a}$ & $51.52^{b}$ & $51.83^{b}$ & 0.03 & $* * *$ \\
\hline Lactose & 47.06 & 47.90 & 48.32 & 0.01 & $* * *$ \\
\hline Total solids & $186.57^{a}$ & $176.66^{b}$ & $174.35^{b}$ & 0.08 & $* * *$ \\
\hline Somatic cell counts & 3.64 & 3.62 & 3.63 & 0.08 & NS \\
\hline Mesophilic aerobic microbiota & 4.87 & 4.98 & 4.90 & 0.03 & NS \\
\hline
\end{tabular}

a-bSame row with different superscripts differ $(P \leq 0.05)$.

$x$ Fat, protein, lactose and total solids expressed as $\mathrm{g} / \mathrm{kg}$ milk.

Somatic cell counts expressed as cells $/ \mathrm{g}\left(\times 10^{5}\right)$.

Mesophilic aerobic microbiota expressed as $\log _{10} \mathrm{cfu} / \mathrm{g}$.

${ }^{+}$Diet $\mathrm{G} 1$ consisting of $50 \%$ grazing + alfalfa silage $(200 \mathrm{~g}$ of dry matter/animal and day) + barley grains $(250 \mathrm{~g}$ of dry matter/animal and day); Diet G2 consisting of $25 \%$ grazing + alfalfa silage ( $600 \mathrm{~g}$ of dry matter/animal and day) + hay (600 g of dry matter/animal and day); Diet G3 consisting of alfalfa silage (600 g of dry matter/animal and day) + hay (500 g of dry matter/animal and day) + commercial concentrate mix (2 kg of dry matter/animal and day; granulated feed, corn grain, granulated dehydrated alfalfa, cotton seed, beet pulp, treacle).

NS $P>0.05 ; * * * \leq 0.001$.

At present, there are attempts to use the somatic cell count (SCC) as the criterion for establishing milk prices, but there is currently no legislation defining the limits of SCC, 
as this depends on a variety of factors (Vivar-Quintana et al. 2006). The average concentration of SCC in milk samples was $3.63 \times 10^{5}$ cells/g and the average concentration for the mesophilic aerobic microbiota counts was $4.90 \log _{10} \mathrm{cfu} / \mathrm{g}$. In accordance with the Ministerial Order of 27 June 1985, the samples could be classified as class 2 , as established by this legislation, since they presented $<6 \log _{10} \mathrm{cfu} / \mathrm{g}$.

\section{Descriptive statistics}

Table 2 shows the average proportions of the 32 FAs and seven groups of FAs for the 120 bulk tank sheep milk samples studied. The variation coefficients were between 52.54 and $7.46 \%$; the average proportions of SFA (66.65\%), MUFA (26.57\%) and PUFA (6.78\%) were different to those described in sheep milk by De La Fuente et al. (2009). These authors reported finding $71.35 \%$ SFA, $22.10 \%$ MUFA and $6.54 \%$ PUFA, obtaining a lower UFA/SFA ratio (0.40) than in the present study (0.50).

In the present study, the average proportion of a-linolenic acid in the sheep milk samples was $0.99 \mathrm{~g} / 100 \mathrm{~g}$ total FAs, coinciding with the values obtained by Zhang et al. (2006). However, Pellattiero et al. (2015) found a lower a-linolenic acid content $(0.30 \mathrm{~g} / 100$ $\mathrm{g}$ total FAs) in their study of sheep milk samples.

In the bulk tank milk samples, there was a higher average proportion of CLA isomer $\mathrm{C}_{18: 2}$ cis-9,trans-11 (0.79 g/100 g total FAs) than of $\mathrm{C}_{18: 2}$ trans-10, cis-12 (0.12 g/100 g total FAs). Renobales et al. (2012) noted that the CLA isomer $\mathrm{C}_{18: 2}$ cis-9,trans-11 accounts for between 70 and $90 \%$ of the total CLA content in milk fat. The proportion of both isomers in the milk samples studied coincided with the range of values reported by Tsiplakou et al. (2006) and De La Fuente et al. (2009).

The percentage of variance explained by the sources of variation studied for the 12 FAs, seven groups of FAs and the five FA indexes selected is shown in Table 3.

\section{Feeding regimen effect}

The feeding regimen was the most important source of variation for $\mathrm{C}_{18: 2}$ cis-9, trans$11 / \mathrm{C}_{18: 2}$ cis-9, cis-12 ratio and DI. This factor also explained a high percentage of variance for omega-6/omega-3 ratio, $\mathrm{C}_{18: 2}$ cis-9,trans-11 (CLA) and $\mathrm{C}_{18: 2}$ trans-10,cis-12 (CLA) proportions (Table 3).

Table 4 shows that significant differences were found $(P \leq 0.05)$ between the three groups studied with respect to the proportions of $\mathrm{C}_{18: 2}$ cis-9,cis-12, $\mathrm{C}_{18: 3}$ cis-9, cis-12, cis-15, $\mathrm{C}_{18: 2}$ cis-9,trans-11 (CLA), $\mathrm{C}_{18: 2}$ trans-10, cis-12 (CLA), the omega-6/omega-3 ratio, AI, $\mathrm{C}_{18: 2}$ cis-9, trans-11/C $\mathrm{C}_{18: 2}$ cis-9, cis-12 and DI. However, no significant differences $(P>0.05)$ in proportion were found for most of the SFA and MUFA. However, bulk tank milk from the G1 presented the lowest proportion of $\mathrm{C}_{18: 2}$ cis-9,cis-12 but had the highest mean proportion of a-linolenic acid and total CLA, and the most beneficial values for the omega6/omega-3 ratio, AI, $\mathrm{C}_{18: 2}$ cis-9,trans- $11 / \mathrm{C}_{18: 2}$ cis-9,cis-12 ratio and DI. The lower $\mathrm{C}_{18: 2}$ cis9,cis-12 proportion and higher total CLA proportion presented by milk from G1 with respect to those from the other two groups studied may be due to greater bioconversion of $\mathrm{C}_{18: 2}$ cis-9,cis-12 in the rumen and mammary gland. These differences could be partially explained by the variation in $\Delta-9$ desaturase activity (in the mammary gland) which can be calculated by means of specific FA indexes as indicated by Arnould and Soyeurt (2009). 
Table 2. Descriptive statistics for composition of the 32 FAs, seven groups of FAs, and five FA indexes for 120 sheep bulk tank milk samples from the 30 flocks studied.

\begin{tabular}{|c|c|c|c|c|c|}
\hline \multirow{2}{*}{ Variable* } & \multirow{2}{*}{$\begin{array}{l}\text { Mean } \\
\text { (g/100 g total FA) }\end{array}$} & \multicolumn{2}{|c|}{ Range } & \multirow{2}{*}{ SD } & \multirow{2}{*}{ CV (\%) } \\
\hline & & Minimum & Maximum & & \\
\hline $\mathrm{C} 4: 0$ & 2.95 & 0.85 & 6.11 & 1.55 & 52.54 \\
\hline C6:0 & 4.98 & 3.15 & 6.90 & 0.63 & 12.65 \\
\hline C8:0 & 3.68 & 2.30 & 5.43 & 0.50 & 13.59 \\
\hline C10:0 & 5.58 & 3.93 & 6.97 & 0.68 & 12.19 \\
\hline $\mathrm{C} 11: 0$ & 0.27 & 0.15 & 0.44 & 0.06 & 22.22 \\
\hline $\mathrm{C} 12: 0$ & 4.20 & 2.92 & 5.46 & 0.53 & 12.62 \\
\hline C13:0 & 0.29 & 0.19 & 0.52 & 0.06 & 20.69 \\
\hline $\mathrm{C} 14: 0$ & 8.38 & 6.93 & 9.90 & 0.62 & 7.39 \\
\hline $\mathrm{C} 14: 1 c-9$ & 0.98 & 0.70 & 1.36 & 0.12 & 12.24 \\
\hline C15:0 & 1.51 & 1.10 & 2.10 & 0.19 & 12.58 \\
\hline $\mathrm{C} 15: 1 c-10$ & 0.45 & 0.30 & 0.81 & 0.08 & 17.78 \\
\hline $\mathrm{C} 16: 0$ & 18.78 & 15.83 & 25.63 & 1.29 & 6.87 \\
\hline C16:1 $c-9$ & 3.14 & 1.44 & 4.24 & 0.41 & 13.06 \\
\hline $\mathrm{C} 17: 0$ & 1.23 & 0.79 & 1.92 & 0.18 & 14.63 \\
\hline $\mathrm{C} 17: 1 \quad c-10$ & 0.64 & 0.44 & 0.97 & 0.11 & 17.19 \\
\hline $\mathrm{C} 18: 0$ & 13.50 & 9.14 & 20.41 & 2.18 & 16.15 \\
\hline $\mathrm{C} 18: 1 c-9+t-11$ & 21.15 & 13.23 & 29.10 & 1.38 & 7.63 \\
\hline $\mathrm{C} 18: 2 t-9, t-12$ & 0.37 & 0.09 & 1.17 & 0.16 & 43.24 \\
\hline $\mathrm{C} 18: 2 c-9, c-12$ & 3.65 & 2.52 & 5.52 & 0.57 & 15.62 \\
\hline C20:0 & 0.62 & 0.37 & 1.05 & 0.12 & 19.34 \\
\hline C18:3 c-9,c-12,c-15 & 0.99 & 0.44 & 1.94 & 0.29 & 29.29 \\
\hline C18:2 c-9,t-11 (CLA) & 0.78 & 0.32 & 2.04 & 0.25 & 32.05 \\
\hline C18:2 t- 10,c-12 (CLA) & 0.12 & 0.04 & 0.35 & 0.04 & 33.33 \\
\hline $\mathrm{C} 20: 2 c-11, c-19$ & 0.06 & 0.04 & 0.10 & 0.01 & 16.67 \\
\hline $\mathrm{C} 22: 0$ & 0.23 & 0.16 & 0.37 & 0.04 & 17.39 \\
\hline $\mathrm{C} 20: 4 c-5, c-8, c-11, c-14$ & 0.22 & 0.15 & 0.32 & 0.02 & 9.09 \\
\hline
\end{tabular}

${ }^{*}$ CLA, conjugated linoleic acid; SCFA, sum of short-chain saturated fatty acids; MCFA, sum of medium-chain saturated fatty acids; LCFA, sum of long-chain saturated fatty acids; MUFA, sum of monounsaturated fatty acids; PUFA, sum of polyunsaturated fatty acids; UFA, sum of unsaturated fatty acids; SFA, sum of saturated fatty acids; AI, atherogenicity index; DI, desaturase index. 
Table 2 (continuation). Descriptive statistics for composition of the 32 FAs, seven groups of FAs, and five FA indexes for 120 sheep bulk tank milk samples from the 30 flocks studied.

\begin{tabular}{|c|c|c|c|c|c|}
\hline \multirow{2}{*}{ Variable* $^{*}$} & \multirow{2}{*}{$\begin{array}{l}\text { Mean } \\
\text { (g/100 g total FA) }\end{array}$} & \multicolumn{2}{|c|}{ Range } & \multirow{2}{*}{ SD } & \multirow{2}{*}{ CV $(\%)$} \\
\hline & & Minimum & Maximum & & \\
\hline $\mathrm{C} 23: 0$ & 0.25 & 0.18 & 0.39 & 0.04 & 16.00 \\
\hline $\mathrm{C} 22: 2 c-13, c-16$ & 0.18 & 0.11 & 0.37 & 0.05 & 27.78 \\
\hline $\mathrm{C} 20: 5 c-5, c-8, c-11, c-14, c-17$ & 0.12 & 0.01 & 0.22 & 0.04 & 33.33 \\
\hline $\mathrm{C} 24: 0$ & 0.20 & 0.14 & 0.30 & 0.03 & 15.00 \\
\hline $\mathrm{C} 24: 1 \quad c-15$ & 0.22 & 0.13 & 0.38 & 0.04 & 18.18 \\
\hline $\mathrm{C} 22: 6 c-4, c-7, c-10, c-13, c-16, c-19$ & 0.28 & 0.17 & 0.43 & 0.05 & 17.86 \\
\hline SCFA & 17.20 & 10.89 & 21.88 & 2.03 & 11.80 \\
\hline MCFA & 16.08 & 12.77 & 19.46 & 1.38 & 8.58 \\
\hline LCFA & 66.72 & 61.45 & 75.16 & 2.65 & 3.97 \\
\hline MUFA & 26.57 & 21.78 & 30.74 & 1.41 & 5.31 \\
\hline PUFA & 6.78 & 5.00 & 8.87 & 0.76 & 11.21 \\
\hline Omega-6 & 3.94 & 2.75 & 5.92 & 0.59 & 14.97 \\
\hline Omega-3 & 1.39 & 0.74 & 2.55 & 0.34 & 24.46 \\
\hline UFA/SFA & 0.50 & 0.40 & 0.60 & 0.04 & 7.46 \\
\hline Omega-6/omega-3 & 3.52 & 1.82 & 6.75 & 0.96 & 27.27 \\
\hline AI & 1.70 & 1.30 & 2.15 & 0.16 & 9.41 \\
\hline $\mathrm{C} 18: 2 c-9, t-11 / \mathrm{C} 18: 2 c-9, c-12$ & 0.22 & 0.10 & 0.77 & 0.08 & 36.36 \\
\hline DI & 0.12 & 0.08 & 0.17 & 0.01 & 8.33 \\
\hline
\end{tabular}

${ }^{*}$ CLA, conjugated linoleic acid; SCFA, sum of short-chain saturated fatty acids; MCFA, sum of medium-chain saturated fatty acids; LCFA, sum of long-chain saturated fatty acids; MUFA, sum of monounsaturated fatty acids; PUFA, sum of polyunsaturated fatty acids; UFA, sum of unsaturated fatty acids; SFA, sum of saturated fatty acids; AI, atherogenicity index; DI, desaturase index. 
The $\Delta-9$ desaturase enzyme adds a double bond at position 9 and configuration cis to MUFA and PUFA with a carbon chain length from 10 to 18 atoms. The most reliable of the ratios used to determine $\Delta-9$ desaturase enzyme activity in milk is the $\mathrm{C}_{14: 1} / \mathrm{C}_{14: 0}$ ratio. This is because the myristoleic acid present in milk is generated almost exclusively (over $95 \%$ ) by endogenous synthesis from myristic acid, in contrast with the other MUFA, which can also come from the diet (Griinari et al. 2000; Renna et al. 2012). The results obtained in the present study confirm this, as G1 presented a higher value $(0.13)$ for the $\mathrm{C}_{14: 1} / \mathrm{C}_{14: 0}$ index than G3 (0.10) or G2 (0.10). Lock and Garnsworthy (2003) observed that sheep fed under a grazing system showed an increase in $\Delta-9$ desaturase activity in the mammary gland. This same trend in $\Delta-9$ desaturase activity was observed by Renna et al. (2012) in their study of the FA profile in milk from goats fed with different levels of fresh forages. The CLA proportion observed by these authors and by Couvreur et al. (2006) in the study of the CLA proportion in dairy cow milk was higher than that found in our study. This fact can be justified by differences in the botanical composition of fresh pastures as well as that the flocks studied in this work were commercial and not experimental.

Table 3. Percentage of variance explained by each fixed effect for the 12 FAs, seven groups of FAs, and five FA indexes considered.

\begin{tabular}{lcccc} 
Variable $^{*}$ & Feeding regimen & Lactation stage & Flock & $\begin{array}{c}\text { Sampling } \\
\text { month }\end{array}$ \\
C8:0 & 0.00 & 4.18 & 17.65 & 38.75 \\
C10:0 & 0.00 & 3.35 & 27.68 & 36.76 \\
C12:0 & 0.00 & 3.81 & 28.97 & 33.15 \\
C14:0 & 0.00 & 3.80 & 18.10 & 34.97 \\
C16:0 & 1.03 & 2.85 & 13.22 & 36.75 \\
C18:0 & 0.00 & 1.33 & 21.37 & 29.52 \\
C18:1 & 0.00 & 2.20 & 7.10 & 43.12 \\
C18:2 c-9,c-12 & 14.21 & 3.22 & 24.25 & 25.20 \\
C18:3 c-9,c-12,c-15 & 18.36 & 1.94 & 24.96 & 23.35 \\
C18:2 c-9,t-11 (CLA) & 21.58 & 0.98 & 15.26 & 30.25 \\
C18:2 $t-10, c-12$ (CLA) & 22.46 & 1.86 & 8.70 & 25.50 \\
C20:4 c-5,c-8,c-11,c-14 & 0.00 & 0.40 & 18.23 & 21.81 \\
SCFA & 0.00 & 4.01 & 18.29 & 31.38 \\
MCFA & 0.00 & 3.98 & 21.82 & 35.11 \\
LCFA & 0.00 & 2.27 & 8.35 & 38.60 \\
MUFA & 0.00 & 3.05 & 5.58 & 42.24 \\
PUFA & 11.26 & 3.27 & 4.08 & 42.43 \\
Omega-6 & 6.75 & 3.64 & 19.45 & 34.29 \\
Omega-3 & 17.22 & 3.20 & 18.80 & 32.40 \\
UFA/SFA & 0.00 & 1.84 & 45.68 & 8.50 \\
Omega-6/omega-3 & 30.42 & 3.66 & 41.95 & 3.27 \\
AI & 12.03 & 0.05 & 47.36 & 4.85 \\
DI 2 c-9,t-11/ C18:2 c-9,c-12 & 56.29 & 0.14 & 20.93 & 3.77 \\
\hline CLA conjugated & 58.75 & 0.10 & 19.72 & 2.34 \\
\hline
\end{tabular}

${ }^{*}$ CLA, conjugated linoleic acid; SCFA, sum of short-chain saturated fatty acids; MCFA, sum of medium-chain saturated fatty acids; LCFA, sum of long-chain saturated fatty acids; MUFA, sum of monounsaturated fatty acids; PUFA, sum of polyunsaturated fatty acids; UFA, sum of unsaturated fatty acids; SFA, sum of saturated fatty acids; AI, atherogenicity index; DI, desaturase index.

Milk form the G1 farms had a lower omega-6/omega-3 ratio than the G2 and the G3 farms which may be explained by high $\mathrm{C}_{18: 3}$ intakes from pasture herbage. However, the changes described in the milk FA profile are not only due to the supply of grass in the animal diet. Preserved forages and concentrate in the sheep diet also influence the FA milk 
profile. As shown in Table 4, G3 presented the lowest concentration of CLA and C $18: 3$ cis9 ,cis-12,cis-15 with respect to the other two groups. This is because it was the only one fed on forage and concentrate. As indicated by Chillard et al. (2007), this type of diet does not contribute to elevated CLA proportions in milk, as it does not provide sufficient amounts of CLA precursors. The G1 diet had a lower forage proportion than G2, but more grazing and higher CLA proportion. Therefore, the factors that may affect the proportions of these beneficial FAs in milk could be the level of precursor intake and the extent of biohydrogenation in the rumen. Incomplete biohydrogenation occurs when grazing yields more $\mathrm{C}_{18: 1}$ trans-11 that can be desaturated in the mammary gland. The rumen environment may be affected by diet, which may be translated into a change in the FA profile of sheep milk (Tsiplakou et al. 2006).

Table 4. Least squares means and standard errors for FA content (g/100 g total FA) by feeding regimen in commercial dairy sheep flocks.

\begin{tabular}{|c|c|c|c|c|c|}
\hline \multirow[b]{2}{*}{ Variable $x$} & \multicolumn{3}{|c|}{ Feeding regimen ${ }^{+}$} & \multirow[b]{2}{*}{ SE } & \multirow[b]{2}{*}{ P-value } \\
\hline & $\begin{array}{c}\text { Group 1 } \\
(n=40)\end{array}$ & $\begin{array}{c}\text { Group } 2 \\
(n=40)\end{array}$ & $\begin{array}{c}\text { Group } 3 \\
(n=40)\end{array}$ & & \\
\hline $\mathrm{C} 8: 0$ & 3.67 & 3.52 & 3.55 & 0.07 & NS \\
\hline $\mathrm{C} 10: 0$ & 5.33 & 5.32 & 5.46 & 0.09 & NS \\
\hline C12:0 & 11.46 & 10.44 & 11.83 & 0.07 & NS \\
\hline C $14: 0$ & 8.15 & 8.13 & 8.29 & 0.08 & NS \\
\hline C16:0 & $17.67^{b}$ & $18.21^{\mathrm{ab}}$ & $18.65^{\mathrm{a}}$ & 0.17 & $* *$ \\
\hline C18:0 & 13.93 & 14.59 & 14.63 & 0.23 & NS \\
\hline C18:1 & 20.94 & 21.60 & 21.62 & 0.21 & NS \\
\hline $\mathrm{C} 18: 2 c-9, c-12$ & $3.03^{c}$ & $3.60^{\mathrm{b}}$ & $4.00^{a}$ & 0.07 & $* * *$ \\
\hline $\mathrm{C} 18: 3 c-9, c-12, c-15$ & $1.25^{\mathrm{a}}$ & $0.91^{b}$ & $0.95^{b}$ & 0.04 & $* * *$ \\
\hline $\mathrm{C} 18: 2 c-9, t-11$ (CLA) & $0.99^{a}$ & $0.79^{\mathrm{b}}$ & $0.71^{c}$ & 0.03 & $* * *$ \\
\hline C18:2 $t-10, c-12$ (CLA) & $0.17^{\mathrm{a}}$ & $0.11^{\mathrm{b}}$ & $0.08^{c}$ & 0.01 & $* * *$ \\
\hline $\mathrm{C} 20: 4 c-5, c-8, c-11, c-14$ & 0.22 & 0.23 & 0.22 & 0.00 & NS \\
\hline SCFA & 17.04 & 17.11 & 17.10 & 0.14 & NS \\
\hline MCFA & 15.46 & 15.43 & 15.44 & 0.19 & NS \\
\hline LCFA & 67.50 & 67.46 & 67.46 & 0.31 & NS \\
\hline MUFA & 26.89 & 26.65 & 26.84 & 0.25 & NS \\
\hline PUFA & $6.92^{a}$ & $6.47^{\mathrm{b}}$ & $6.99^{a}$ & 0.11 & $* *$ \\
\hline Omega-6 & $3.31^{\mathrm{c}}$ & $3.38^{b}$ & $4.30^{\mathrm{a}}$ & 0.07 & $* * *$ \\
\hline Omega-3 & $1.74^{\mathrm{a}}$ & $1.27^{\mathrm{b}}$ & $1.26^{\mathrm{b}}$ & 0.04 & $* * *$ \\
\hline UFA/SFA & 0.51 & 0.47 & 0.50 & 0.01 & NS \\
\hline Omega-6/omega-3 & $1.90^{c}$ & $2.66^{\mathrm{b}}$ & $3.41^{\mathrm{a}}$ & 0.09 & $* * *$ \\
\hline AI & $1.59^{\mathrm{b}}$ & $1.84^{a}$ & $1.88^{\mathrm{a}}$ & 0.02 & $* * *$ \\
\hline $\mathrm{C} 18: 2 c-9, t-11 / \mathrm{C} 18: 2 c-9, c-12$ & $0.33^{a}$ & $0.22^{\mathrm{b}}$ & $0.18^{\mathrm{b}}$ & 0.01 & $* * *$ \\
\hline DI & $0.13^{\mathrm{a}}$ & $0.10^{\mathrm{b}}$ & $0.10^{\mathrm{b}}$ & 0.09 & $* * *$ \\
\hline
\end{tabular}

a-c Same row with different superscripts differ $(P \leq 0.05)$.

x CLA, conjugated linoleic acid; SCFA, sum of short-chain saturated fatty acids; MCFA, sum of medium-chain saturated fatty acids; LCFA, sum of long-chain saturated fatty acids; MUFA, sum of monounsaturated fatty acids; PUFA, sum of polyunsaturated fatty acids; UFA, sum of unsaturated fatty acids; SFA, sum of saturated fatty acids; AI, atherogenicity index; DI, desaturase index.

${ }^{+}$Diet G1 consisting of $50 \%$ grazing + alfalfa silage (200 g of dry matter/animal and day) + barley grains (250 g of dry matter/animal and day); Diet G2 consisting of $25 \%$ grazing + alfalfa silage ( $600 \mathrm{~g}$ of dry matter/animal and day) + hay (600 g of dry matter/animal and day); Diet G3 consisting of 0\% grazing, alfalfa silage (600 g of dry matter/animal and day) + hay (500 g of dry matter/animal and day) + commercial concentrate mix ( $2 \mathrm{~kg}$ of dry matter/animal and day; granulated feed, corn grain, granulated dehydrated alfalfa, cotton seed, beet pulp, treacle).

NS $P>0.05 ;{ }^{* *} P \leq 0.01 ;{ }^{* * *} P \leq 0.001$. 


\section{Lactation stage effect}

Lactation stage accounted for $<4.18 \%$ of variance in the $12 \mathrm{FAs}$, seven groups of FAs and five FA indexes and was therefore much less important as regards variation than the other factors (Table 3). This is in agreement with other authors (De La Fuente et al. 2009; Peterson et al. 2002). Lactation stage had a significant effect $(P \leq 0.05)$ on the proportions of $\mathrm{C}_{10: 0}, \mathrm{C}_{12: 0}, \mathrm{C}_{14: 0}, \mathrm{C}_{18: 0}$, PUFA, omega-6 and omega-3 (Table 5). Bulk tank milk obtained in the final lactation stage showed higher proportion of these FAs than bulk tank milk obtained in the initial lactation stage. As Nogalski et al. (2012) have indicated, the differences observed in the proportions of FAs between the initial lactation stage and the final lactation stage could be due to more intense fat reserve mobilisation in the early lactation stage.

Table 5. Least squares means and standard errors for FA content (g/100 g total FA) by lactation stage in commercial dairy sheep flocks.

\begin{tabular}{|c|c|c|c|c|c|}
\hline \multirow[b]{2}{*}{ Variable $x$} & \multicolumn{3}{|c|}{ Lactation stage ${ }^{+}$} & \multirow[b]{2}{*}{ SE } & \multirow[b]{2}{*}{ P-value } \\
\hline & $\begin{array}{l}\text { Initial } \\
(\mathbf{n}=37)\end{array}$ & $\begin{array}{l}\text { Middle } \\
\text { (n=48) }\end{array}$ & $\begin{array}{c}\text { Final } \\
(\mathbf{n}=\mathbf{3 5})\end{array}$ & & \\
\hline $\mathrm{C} 8: 0$ & 3.43 & 3.51 & 3.76 & 0.09 & NS \\
\hline C10:0 & $5.08^{\mathrm{b}}$ & $5.36^{\mathrm{ab}}$ & $5.51^{\mathrm{a}}$ & 0.08 & $*$ \\
\hline $\mathrm{C} 12: 0$ & $3.84^{\mathrm{b}}$ & $3.99^{b}$ & $4.22^{\mathrm{a}}$ & 0.07 & * \\
\hline $\mathrm{C} 14: 0$ & $8.24^{b}$ & $8.26^{b}$ & $8.52^{\mathrm{a}}$ & 0.08 & * \\
\hline C16:0 & 18.13 & 18.20 & 18.50 & 0.20 & NS \\
\hline C18:0 & $13.59^{\mathrm{b}}$ & $14.50^{\mathrm{a}}$ & $15.27^{\mathrm{a}}$ & 0.16 & * \\
\hline C18:1 & 21.08 & 21.48 & 21.61 & 0.21 & NS \\
\hline C18:2 $c-9, c-12$ & 3.51 & 3.56 & 3.58 & 0.09 & NS \\
\hline $\mathrm{C} 18: 3 c-9, c-12, c-15$ & $0.87^{\mathrm{b}}$ & $0.95^{\mathrm{ab}}$ & $1.19^{\mathrm{a}}$ & 0.05 & $* *$ \\
\hline $\mathrm{C} 18: 2 c-9, t-11$ (CLA) & 0.87 & 0.85 & 0.85 & 0.01 & NS \\
\hline $\mathrm{C} 18: 2 t-10, c-12$ (CLA) & 0.13 & 0.12 & 0.12 & 0.01 & NS \\
\hline $\mathrm{C} 20: 4 c-5, c-8, c-11, c-14$ & 0.22 & 0.22 & 0.22 & 0.00 & NS \\
\hline SCFA & 17.29 & 17.12 & 17.09 & 0.26 & NS \\
\hline MCFA & 15.21 & 15.38 & 15.37 & 0.20 & NS \\
\hline LCFA & 67.50 & 67.50 & 67.54 & 0.36 & NS \\
\hline MUFA & 26.67 & 26.90 & 26.95 & 0.30 & NS \\
\hline PUFA & $6.53^{\mathrm{b}}$ & $6.76^{\mathrm{ab}}$ & $6.92^{\mathrm{a}}$ & 0.08 & $*$ \\
\hline Omega-6 & $3.65^{b}$ & $3.69^{b}$ & $3.87^{a}$ & 0.02 & * \\
\hline Omega-3 & $1.25^{\mathrm{b}}$ & $1.34^{\mathrm{ab}}$ & $1.65^{\mathrm{a}}$ & 0.06 & * \\
\hline UFA/SFA & 0.50 & 0.50 & 0.51 & 0.02 & NS \\
\hline Omega-6/omega-3 & $2.92^{\mathrm{a}}$ & $2.75^{\mathrm{ab}}$ & $2.36^{b}$ & 0.10 & $* *$ \\
\hline $\mathrm{AI}$ & 1.65 & 1.64 & 1.67 & 0.02 & NS \\
\hline $\mathrm{C} 18: 2 c-9, t-11 / \mathrm{C} 18: 2 c-9, c-12$ & 0.25 & 0.24 & 0.24 & 0.01 & NS \\
\hline DI & 0.10 & 0.10 & 0.10 & 0.11 & NS \\
\hline
\end{tabular}

a-c Same row with different superscripts differ $(P \leq 0.05)$.

x CLA, conjugated linoleic acid; SCFA, sum of short-chain saturated fatty acids; MCFA, sum of medium-chain saturated fatty acids; LCFA, sum of long-chain saturated fatty acids; MUFA, sum of monounsaturated fatty acids; PUFA, sum of polyunsaturated fatty acids; UFA, sum of unsaturated fatty acids; SFA, sum of saturated fatty acids; AI, atherogenicity index; DI, desaturase index.

+ Initial: 20-60 days postpartum; Middle: 60-110 days postpartum; Final: 110-160 days postpartum. NS $P>0.05 ;{ }^{*} P \leq 0.05 ;{ }^{* *} P \leq 0.01$

The proportions of CLA isomers and DI were not affected $(P>0.05)$ by the lactation stage. However, several recent studies have shown that in dairy cattle, the lactation stage effect on CLA proportion and DI was significant (Kelsey et al. 2003; Craninx et al. 2008; Bilal et al. 2014). This may be due to the fact that the management system in dairy cattle is different from dairy sheep and to the physiological differences between both species. 


\section{Sampling month effect}

According to the percentage of variance analysis (Table 3), sampling month was the most important source of variation for the majority of individual FA, SFA, MUFA, PUFA, the two CLA isomers and a-linolenic acid, in agreement with the results reported by Cabiddu et al. (2005). This may be because the composition of the fresh herbage forming the groups' diet may have varied according to the month, and these variations have in turn been found to affect the FA profile of sheep milk (Cabiddu et al. 2005).

As can be seen in Table 6, the highest average proportions for the majority of the FAs studied in bulk tank milk were observed in April, except for $\mathrm{C}_{14: 0}, \mathrm{C}_{16: 0}, \mathrm{C}_{20: 4}$, SFA and omega-6. Furthermore, samples collected in April and May yielded better UFA/SFA and $\mathrm{C}_{18: 2}$ cis-9,trans-11/ $\mathrm{C}_{18: 2}$ cis-9, cis-12 ratios and lower AI than samples collected in June and July. The values obtained for the AI were consistent with those reported by Chillard et al. (2003). The only variable for which no significant differences $(P>0.05)$ were found between sampling months was the DI.

Table 6. Least squares means and standard errors for FA content (g/100g total FA) in sheep milk from commercial dairy flocks by sampling month.

\begin{tabular}{|c|c|c|c|c|c|c|c|}
\hline \multirow[b]{2}{*}{ Variablex } & \multicolumn{4}{|c|}{ Sampling month } & \multirow[b]{2}{*}{ SE } & \multicolumn{2}{|c|}{ P-value $^{+}$} \\
\hline & $\begin{array}{c}\text { April } \\
(n=30)\end{array}$ & $\begin{array}{c}\text { May } \\
(n=30)\end{array}$ & $\begin{array}{c}\text { June } \\
(n=30)\end{array}$ & $\begin{array}{c}\text { July } \\
(\mathbf{n}=\mathbf{3 0})\end{array}$ & & $\mathbf{M}$ & $\mathbf{M} * \mathbf{R}$ \\
\hline $\mathrm{C} 8: 0$ & $3.77^{a}$ & $3.57^{\mathrm{b}}$ & $3.52^{\mathrm{b}}$ & $3.45^{c}$ & 0.08 & $* * *$ & NS \\
\hline C10:0 & $5.54^{a}$ & $5.43^{a}$ & $5.28^{b}$ & $5.16^{\mathrm{b}}$ & 0.11 & $* * *$ & NS \\
\hline C $12: 0$ & $4.19^{a}$ & $4.13^{a}$ & $3.98^{b}$ & $3.81^{\mathrm{c}}$ & 0.09 & $* * *$ & NS \\
\hline C $14: 0$ & $8.26^{\mathrm{b}}$ & $7.93^{c}$ & $8.13^{\mathrm{b}}$ & $8.45^{\mathrm{a}}$ & 0.11 & $* * *$ & NS \\
\hline C16:0 & $17.68^{b}$ & $18.05^{\mathrm{ab}}$ & $18.64^{\mathrm{ab}}$ & $18.80^{\mathrm{a}}$ & 0.23 & $* * *$ & NS \\
\hline $\mathrm{C} 18: 0$ & $14.25^{\mathrm{ab}}$ & $14.72^{\mathrm{a}}$ & $14.52^{\mathrm{ab}}$ & $14.03^{b}$ & 0.35 & $* * *$ & NS \\
\hline C18:1 & $21.78^{a}$ & $21.44^{\mathrm{ab}}$ & $21.28^{\mathrm{ab}}$ & $21.03^{\mathrm{b}}$ & 0.26 & $* * *$ & NS \\
\hline $\mathrm{C} 18: 2 c-9, c-12$ & $3.48^{a}$ & $3.36^{\mathrm{b}}$ & $3.43^{c}$ & $3.47^{c}$ & 0.09 & $* * *$ & NS \\
\hline $\mathrm{C} 18: 3 c-9, c-12, c-15$ & $1.10^{\mathrm{a}}$ & $1.07^{\mathrm{ab}}$ & $0.94^{\mathrm{ab}}$ & $0.92^{b}$ & 0.06 & $* * *$ & NS \\
\hline C18:2 c-9,t-11 (CLA) & $0.98^{a}$ & $0.83^{\mathrm{b}}$ & $0.77^{\mathrm{bc}}$ & $0.69^{c}$ & 0.07 & $* * *$ & $* *$ \\
\hline C18:2 t-10,c-12 (CLA) & $0.15^{a}$ & $0.12^{\mathrm{b}}$ & $0.11^{\mathrm{b}}$ & $0.11^{\mathrm{b}}$ & 0.05 & $* *$ & $* *$ \\
\hline $\mathrm{C} 20: 4 c-5, c-8, c-11, c-14$ & $0.21^{\mathrm{b}}$ & $0.21^{b}$ & $0.23^{a}$ & $0.23^{a}$ & 0.01 & $* *$ & NS \\
\hline SCFA & $16.17^{\mathrm{c}}$ & $16.15^{\mathrm{c}}$ & $16.70^{\mathrm{b}}$ & $17.30^{\mathrm{a}}$ & 0.28 & $* * *$ & NS \\
\hline MCFA & $16.09^{a}$ & $16.05^{\mathrm{a}}$ & $15.59^{b}$ & $15.62^{\mathrm{b}}$ & 0.35 & $* *$ & NS \\
\hline LCFA & $67.74^{\mathrm{ab}}$ & $67.80^{a}$ & $67.75^{\mathrm{ab}}$ & $67.08^{\mathrm{b}}$ & 0.33 & $* *$ & NS \\
\hline MUFA & $27.18^{\mathrm{a}}$ & $26.73^{a b}$ & $26.73^{\mathrm{ab}}$ & $26.68^{\mathrm{b}}$ & 0.21 & $* * *$ & NS \\
\hline PUFA & $7.17^{a}$ & $6.67^{a b}$ & $6.59^{b}$ & $6.41^{b}$ & 0.15 & $* * *$ & NS \\
\hline Omega-6 & $3.75^{b}$ & $3.63^{c}$ & $3.76^{\mathrm{b}}$ & $3.94^{a}$ & 0.09 & $* * *$ & NS \\
\hline Omega-3 & $1.56^{\mathrm{a}}$ & $1.46^{\mathrm{b}}$ & $1.35^{\mathrm{c}}$ & $1.31^{\mathrm{c}}$ & 0.06 & $* * *$ & NS \\
\hline UFA / SFA & $0.51^{\mathrm{a}}$ & $0.49^{a b}$ & $0.48^{b}$ & $0.48^{b}$ & 0.03 & ** & NS \\
\hline Omega-6 / omega-3 & $2.40^{\mathrm{b}}$ & $2.49^{b}$ & $2.79^{\mathrm{a}}$ & $3.01^{\mathrm{a}}$ & 0.12 & $* *$ & NS \\
\hline AI & $1.60^{\mathrm{b}}$ & $1.61^{\mathrm{b}}$ & $1.65^{\mathrm{ab}}$ & $1.70^{\mathrm{a}}$ & 0.02 & $* * *$ & NS \\
\hline $\mathrm{C} 18: 2 c-9, t-11 / \mathrm{C} 18: 2 c-9, c-12$ & $0.28^{a}$ & $0.25^{\mathrm{ab}}$ & $0.22^{\mathrm{bc}}$ & $0.20^{c}$ & 0.01 & $* * *$ & $* *$ \\
\hline DI & 0.11 & 0.11 & 0.11 & 0.10 & 0.01 & NS & NS \\
\hline
\end{tabular}

a-c Same row with different superscripts differ $(P \leq 0.05)$.

x CLA, conjugated linoleic acid; SCFA, sum of short-chain saturated fatty acids; MCFA, sum of medium-chain saturated fatty acids; LCFA, sum of long-chain saturated fatty acids; MUFA, sum of monounsaturated fatty acids; PUFA, sum of polyunsaturated fatty acids; UFA, sum of unsaturated fatty acids; SFA, sum of saturated fatty acids; AI, atherogenicity index; DI, desaturase index.

$+\mathrm{M}$ : sampling month fixed effect; $\mathrm{M}^{*} \mathrm{R}$ : interaction effect between sampling month and feeding regimen.

NS $P>0.05 ;{ }^{* *} P \leq 0.01 ;{ }^{* * *} P \leq 0.001$.

Notably, the highest average proportion of total CLA was obtained in April (1.13 $\mathrm{g} / 100 \mathrm{~g}$ total FAs), followed by May (0.95 g/100 g total FAs), June (0.88 g/100 g total FAs) 
and July $(0.80 \mathrm{~g} / 100 \mathrm{~g}$ total FAs). Our results are consistent with those reported by Tsiplakou et al. (2006), who found that the highest values for total CLA in sheep milk were obtained in April and May, whereas the proportion was lowest in January, March and June. The CLA values detected by these authors were higher than the CLA concentration observed in the present study. However, as in our study, they found higher levels of CLA in spring, when fresh herbage is rich in a-linolenic acid (Tsiplakou et al. 2008). The proportion of this FA steadily decreases as the herbage matures and develops higher fibre proportion (Dewhurst et al. 2001). Accordingly, intake of mature herbage deficient in alinolenic acid leads to a reduction in the levels of vaccenic acid, an intermediate generated during biohydrogenation in the rumen. This in turn results in a reduction in CLA synthesised from vaccenic acid in the mammary gland (Nudda et al. 2005). In the present study, it can be observed that the interaction effect between the sampling month and the feeding regimen was significant $(P \leq 0.01)$ for the proportions of CLA and for the $\mathrm{C}_{18: 2}$ cis9, trans-11/C 18:2 cis-9,cis-12 ratio (Table 6). The importance of the grazing time on the proportions of CLA in bulk tank milk can be observed because the milk collected from the G1 and G2 dietary groups in April showed higher proportions of CLA (1.15 and 0.91 g/100 $\mathrm{g}$ total FAs, respectively) and $\mathrm{C}_{18: 2}$ cis-9, trans- $11 / \mathrm{C}_{18: 2}$ cis- 9 , cis- 12 (0.41 and 0.22 , respectively) than the milk collected from the same groups in July which presented 0.82 and $0.65 \mathrm{~g} \mathrm{CLA} / 100 \mathrm{~g}$ of total FA for G1 and G2, respectively, and values of 0.25 (G1) and 0.17 (G2) for the $\mathrm{C}_{18: 2}$ cis-9,trans-11/ $\mathrm{C}_{18: 2}$ cis-9, cis-12 ratio. However, there were not significant differences $(P>0.05)$ between the values for the proportions of CLA $(0.79 \mathrm{~g} / 100$ g total FAs) and $\mathrm{C}_{18: 2}$ cis-9,trans-11/ $\mathrm{C}_{18: 2}$ cis-9, cis-12 (0.19) observed in the milk from G3 group collected in April, May, June or July.

\section{Flock effect}

Table 3 shows that flock was the main source of variation for $\mathrm{C}_{18: 3}$ cis-9, cis-12, cis15 , the UFA/SFA ratio, the omega-6/omega-3 ratio and AI. Similarly, flock explained a large percentage of variance for SCFA and the CLA isomer cis-9, trans-11, in agreement with results obtained by Stoop et al. (2008), who found that flock explained a high percentage of variance for $16 \mathrm{FAs}$, including the CLA isomer cis-9, trans-11.

As shown in Figure 1, there were considerable differences among flocks with regard to FA proportion. In the statistical analysis of flocks, taking into account the average values of the milk FA profile throughout the experimental period, two clusters were formed. This could be because each flock belonged to different farm and animal population. Cluster 1 was formed by the flocks belonging to the dietary group G3 and by some flocks of the G2 group. However, cluster 2 was made up of flocks belonging to the G1 and some flocks of the G2 groups (Figure 1). This last cluster showed higher average proportions of CLA and UFA/SFA ratio than cluster 1, whereas this presented higher average proportions for the $\mathrm{C}_{18: 3}$ cis-9,cis-12, cis-15 and SCFA than cluster 2. Likewise, cluster 2 showed the lowest average values for the omega-6/omega-3 ratio and AI in comparison with cluster 1 . These results were similar to those previously observed when the effect of the feeding regimen was analyzed. 


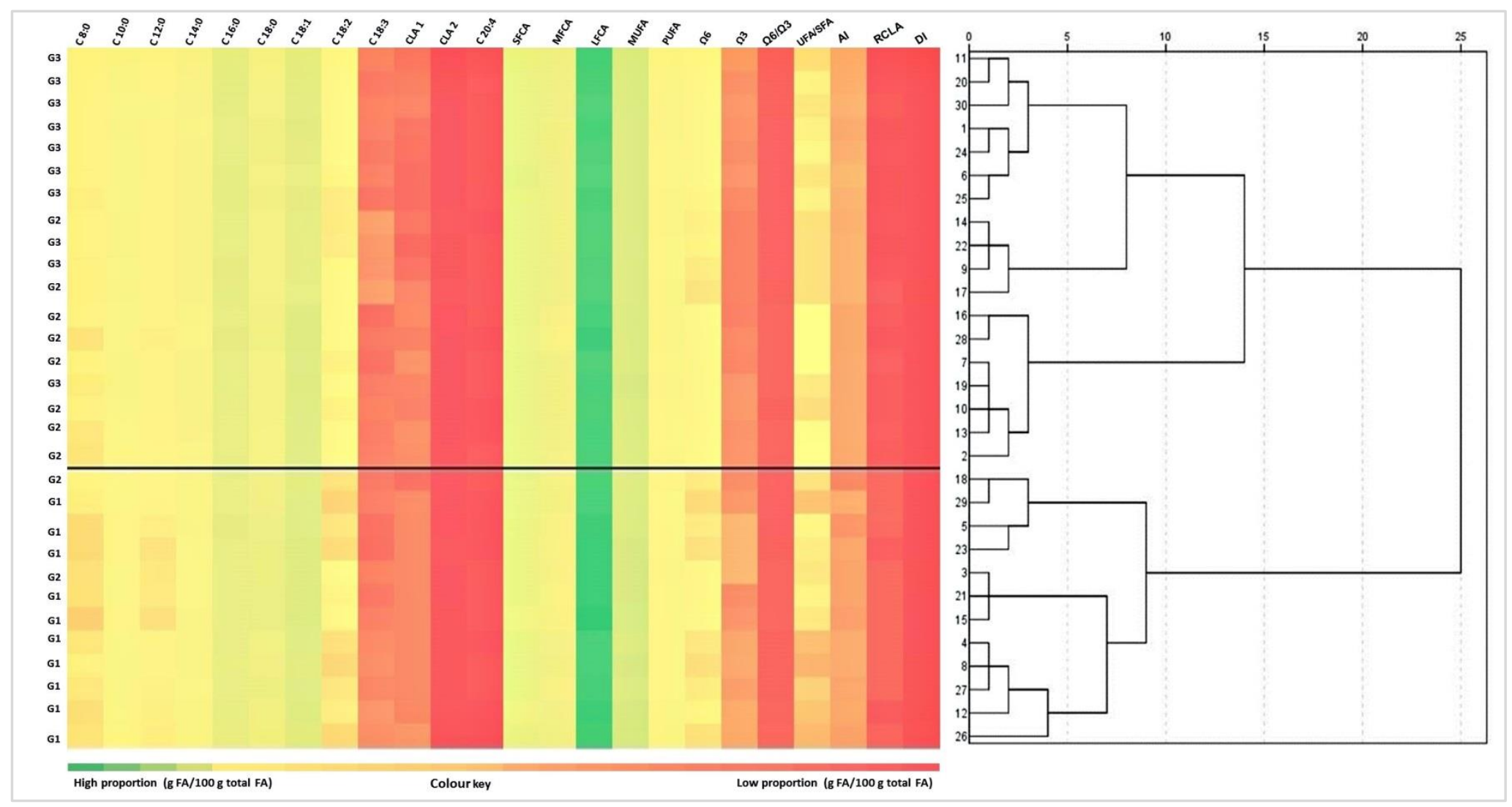

Figure 1. Heatmap with hierarchical clustering of the commercial dairy sheep flocks studied according to the mean values of the 12 FAs, seven groups of FAs and five FA indexes studied during the experimental period.

CLA, conjugated linoleic acid; CLA 1, c-9,t-11 C $18: 2$; CLA 2, $t-10, c-12 \mathrm{C}_{18: 2}$; SCFA, sum of short-chain saturated fatty acids; MCFA, sum of medium-chain saturated fatty acids; LCFA, sum of long-chain saturated fatty acids; MUFA, sum of monounsaturated fatty acids; PUFA, sum of polyunsaturated fatty acids; UFA, sum of unsaturated fatty acids; SFA, sum of saturated fatty acids; AI, atherogenicity index; RCLA, $c-9, t-11 \mathrm{C}_{18: 2} / c-9, c-12 \mathrm{C}_{18: 2}$; DI, desaturase index. 


\section{CONCLUSIONS}

This study showed that the proportions of beneficial FAs, such as CLA and alinolenic acid, decreased in bulk tank milk when sheep grazed less and ate more concentrates. Lactation stage had no effect on MUFA, CLA, linoleic acid or arachidonic acid. At present, sheep milk production is being intensified giving less importance to the nutritional value of the milk. However, less intensive sheep milk production systems have been shown to have a beneficial effect on the nutritional profile of milks. This study provides information that the dairy industry could take into account to foment animal production practices that lead to an improvement in sheep milk quality and therefore in the nutritional value of cheese.

\section{ACKNOWLEDGEMENTS}

The authors are grateful to the University of León (León, Spain) for granting a $\mathrm{PhD}$ fellowship to Erica Renes Bañuelos. The authors also wish to acknowledge the Consortium for Ovine Promotion (Villalpando, Zamora, Castilla-León, Spain), and especially Carmen Garcia Jimeno, for their cooperation.

\section{REFERENCES}

Aldai N, Murray B E, Nájera A I, Troy D J and Osoro K (2005) A Review: Derivatization of fatty acids and its application for conjugated linoleic acid studies in ruminant meat lipids. Journal of the Science of Food and Agriculture 85 1073-1083.

Arnould V R and Soyeurt H (2009) Genetic variability of milk fatty acids. Journal of Applied Genetics 50 29-39.

Bilal G, Cue R I, Mustafa A F and Hayes J F (2014) Effects of parity, age at calving and stage of lactation on fatty acid composition of milk in Canadian Holsteins. Canadian Journal of Animal Science 94 401-410.

Bligh E G and Dyer W J (1959) A rapid method of total lipid extraction and purification. Canadian Journal of Biochemistry and Physiology 37 911-917.

Cabiddu A, Decandia M, Addis M, Piredda G, Pirisi A and Molle G (2005) Managing Mediterranean pastures in order to enhance the level of beneficial fatty acids in sheep milk. Small Ruminant Research 59 169-180.

Chilliard Y, Ferlay A, Rouel J and Lamberet G (2003) A review of nutritional and physiological factors affecting goat milk lipid synthesis and lipolysis. Journal of Dairy Science 86 1751-1770.

Chilliard Y, Glasser F, Ferlay A, Bernard L, Rouel J and Doreau M (2007) Diet, rumen biohydrogenation and nutritional quality of cow and goat milk fat. European Journal of Lipid Science and Technology 109 828-855.

Couvreur S, Hurtaud C, Lopez C, Delaby L and Peyraud J L (2006) The linear relationship between the proportion of fresh grass in the cow diet, milk fatty acid composition, and butter properties. Journal of Dairy Science 89 1956-1969.

Craninx M, Steen A, Van Laar H, Van Nespen T, Martin-Tereso J, De Baets B and Fievez (2008) Effect of lactation stage on the odd-and branched-chain milk fatty acids of 
dairy cattle under grazing and indoor conditions. Journal of Dairy Science $\mathbf{9 1}$ 2662-2677.

De La Fuente L, Barbosa E, Carriedo J, Gonzalo C, Arenas R, Fresno J and San Primitivo F (2009) Factors influencing variation of fatty acid content in ovine milk. Journal of Dairy Science 92 3791-3799.

Dewhurst R J, Scollan N D, Youell S J, Tweed J K and Humphreys M O (2001) Influence of species, cutting date and cutting interval on the fatty acid composition of grasses. Grass and Forage Science 56 68-74.

Elwood P C, Pickering J E, Givens D I and Gallacher JE (2010) The consumption of milk and dairy foods and the incidence of vascular disease and diabetes: an overview of the evidence. Lipids 45 925-939.

Field C J, Blewett H H, Proctor S and Vine D (2009) Human health benefits of vaccenic acid. Applied Physiology, Nutrition, and Metabolism 34 979-991.

Griinari J M, Corl B A, Lacy S H, Chouinard P Y, Nurmela K V V and Bauman D E (2000) Conjugated linoleic acid is synthesized endogenously in lactating dairy cows by 49-desaturase. The Journal of Nutrition 130 2285-2291.

Hervás G, Luna P, Mantecón AR, Castañares N, De la Fuente M A, Juárez M and Frutos P (2008) Effect of diet supplementation with sunflower oil on milk production, fatty acid profile and ruminal fermentation in lactating dairy ewes. Journal of Dairy Research 75 399-405.

Kalac P and Samková E (2010) A review: The effects of feeding various forages on fatty acid composition of bovine milk fat. Czech Journal of Animal Science 55 521-537.

Kelsey J A, Corl B A, Collier R J and Bauman D E (2003) The effect of breed, parity, and stage of lactation on conjugated linoleic acid (CLA) in milk fat from dairy cows. Journal of Dairy Science 86 2588-2597.

Koba K and Yanagita T (2014) Health benefits of conjugated linoleic acid (CLA). Obesity Research \& Clinical Practice 8 525-532.

Kottek M, Grieser J, Beck C, Rudolf B and Rubel, F (2006) World map of the KöppenGeiger climate classification updated. Meteorologische Zeitschrift 15 259-263.

Lock A L and Garnsworthy P C (2003) Seasonal variation in milk conjugated linoleic acid and $\Delta$ 9-desaturase activity in dairy cows. Livestock Production Science 79 47-59.

Mayer H K and Fiechter G (2012) Physical and chemical characteristics of sheep and goat milk in Austria. International Dairy Journal 24 57-63.

Ministerial Order, June 27, 1985, which establishes the payment of milk according to its composition and hygienic quality. B.O.E. 162, July 8, 1985, p.21471 - 21479. Modified by Ministerial Order, December 13, 1985. B.O.E. 304, December 20, 1985, p. 40117-40117.

Morand-Fehr P, Fedele V, Decandia M and Le Frileux Y (2007) Influence of farming and feeding systems on composition and quality of goat and sheep milk. Small Ruminant Research 68 20-34.

Nogalski Z, Jaglowska B, Wielgosz-Groth Z, Pogorzelska-Przybylek P, Sobczuk-Szul M and Mochol M (2012) The effect of parity on the fatty acid profile of milk from highyielding cows. Acta Scientiarum Polonorum. Zootechnica 11 49-56. 
Nudda A, McGuire M A, Battacone G and Pulina G (2005) Seasonal variation in conjugated linoleic acid and vaccenic acid in milk fat of sheep and its transfer to cheese and ricotta. Journal of Dairy Science 88 1311-1319.

Park Y, Juárez M, Ramos M and Haenlein G (2007) Physico-chemical characteristics of goat and sheep milk. Small Ruminant Research 68 88-113.

Pellattiero E, Cecchinato A, Tagliapietra F, Schiavon S and Bittante G (2015) Determination by GC $\times$ GC of fatty acid and conjugated linoleic acid (CLA) isomer profiles in six selected tissues of lambs fed on pasture or on indoor diets with and without rumen-protected CLA. Journal of Agricultural and Food Chemistry 63 963974.

Peterson D G, Kelsey J A and Bauman D E (2002) Analysis of variation in cis-9, trans-11 conjugated linoleic acid (CLA) in milk fat of dairy cows. Journal of Dairy Science $\mathbf{8 5}$ 2164-2172.

Renna M, Cornale P, Lussiana C, Malfatto V, Mimosi A and Battaglini L M (2012) Fatty acid profile of milk from goats fed diets with different levels of conserved and fresh forages. International Journal of Dairy Technology 65 201-207.

Renobales de M, Amores G, Arranz J, Virto M, Barrón L J R, Bustamante M A, Ruiz de Gordoa J C, Nájera A I, Valdivielso I, Abilleira E, Beltrán de Heredia I, PérezElortondo F J, Ruiz R, Albisu M, Mandaluniz N (2012) Part-time grazing improves sheep milk production and its nutritional characteristics. Food Chemistry 130 9096.

Sales-Campos H, Reis de Souza P, Crema Peghini B, Santana da Silva J and Ribeiro Cardoso C (2013) An overview of the modulatory effects of oleic acid in health and disease. Mini Reviews in Medicinal Chemistry 13 201-210.

Shingfield K J, Chilliard Y, Toivonen V, Kairenius P and Givens D I (2008) Trans fatty acids andbioactive lipids in ruminant milk. Advances in Experimental Medicine and Biology 606 3-65.

Sofi F, Buccioni A, Cesari F, Gori A M, Minieri S, Mannini L, Casini A, Gensini G F, Abbate $\mathrm{R}$ and Antongiovanni M (2010) Effects of a dairy product (Pecorino cheese) naturally rich in cis-9, trans-11 conjugated linoleic acid on lipid, inflammatory and haemorheological variables: A dietary intervention study. Nutrition, Metabolism and Cardiovascular Diseases 20 117-124.

Stanton C, Murphy J, McGrath E, Devery R (2003) Animal feeding strategies for conjugated linoleic acid enrichment of milk. In Advances in Conjugated Linoleic Acid Research, 1 st edn, vol. 3 pp 123-145. Sebedio J L, Christie W W, Adolf R,eds. Champaign IL (USA): AOCS Press.

Stoop W M, Van Arendonk J A M, Heck J M L, Van Valenberg H J F and Bovenhuis H (2008) Genetic parameters for major milk fatty acids and milk production traits of Dutch Holstein-Friesians. Journal of Dairy Science 91 385-394.

Tsiplakou E, Mountzouris KC and Zervas G (2006) Concentration of conjugated linoleic acid in grazing sheep and goat milk fat. Livestock Science 103 74-84.

Tsiplakou E, Kominakis A and Zervas G (2008) The interaction between breed and diet on CLA and fatty acids content of milk fat of four sheep breeds kept indoors or at grass. Small Ruminant Research 74 179-187. 
Ulbricht T L V and Southgate D A T (1991) Coronary heart disease: seven dietary factors. Lancet 338 985-992.

Vivar-Quintana A M, Beneitez de la Mano E and Revilla I (2006) Relationship between somatic cell counts and the properties of yogurt made from ewe's milk. International Dairy Journal 16 262-267.

Yang B, Chen H, Stanton C, Ross R P, Zhang H, Chen Y Q and Chen W (2016) Review of the roles of conjugated linoleic acid in health and disease. Journal of Functional Foods 15 314-325.

Zhang R H, Mustafa A F, Ng-Kwai-Hang K F and Zhao X (2006) Effects of freezing on composition and fatty acid profiles of sheep milk and cheese. Small Ruminant Research 64 203-210.

Zlatanos S, Laskaridis K, Feist C and Sagredos A (2002) CLA content and fatty acid composition of Greek Feta and hard cheese. Food Chemistry 78 471-477. 



\title{
CAPÍTULO 2
}

\section{Production of conjugated linoleic acid and gamma-aminobutyric acid by autochthonous lactic acid bacteria and detection of the genes involved}

\author{
Erica Renes ${ }^{1}$, Daniel M. Linares ${ }^{2}$, Leticia González ${ }^{1}$, José Maria Fresno ${ }^{1}$, \\ Maria Eugenia Tornadijo ${ }^{1}$ and Catherine Stanton ${ }^{2}$ \\ ${ }^{1}$ Department of Food Hygiene and Technology, University of León, Spain. 2Department of \\ Food Biosciences, Teagasc Food Research Centre, Moorepark, Ireland.
}

Journal of Functional Foods, 2017, 34, 340-346

Abstract

In this study, 85 strains of lactic acid bacteria isolated from artisanal cheeses were screened to determine their capacity to synthesise bioactive compounds with important beneficial properties to human health, such as conjugated linoleic acid (CLA) and gammaamino butyric acid (GABA).

Four Lactobacillus plantarum and two Lactobacillus casei subsp. casei strains were found to be capable of synthetizing CLA. The highest level of CLA formed in the media after $48 \mathrm{~h}$ incubation was $19.26 \mu \mathrm{g} / \mathrm{mL}$. Six Lactobacillus brevis and four Lactococcus lactis subp. lactis strains were able to produce GABA and the highest concentration $(2524.05 \mu \mathrm{g} / \mathrm{mL})$ was found after $72 \mathrm{~h}$ incubation.

The detection of genes encoding linoleate isomerase could be suitable for use as screening method of CLA-producer strains but many strain-dependent factors affect their expression and/or activity. The detection of genes encoding the glutamate decarboxylase system could be a method for screening Lactococcus lactis GABA-producing strains, although this should be studied in a larger number of strains.

Our findings suggest that the above strains are potential candidates for the design of starter cultures with the capacity to generate bioactive compounds, offering new possibilities for the manufacture of functional dairy products. 



\section{INTRODUCTION}

The relationship between food and consumer health and well-being has become a priority concern in food production. Fermented dairy products, especially cheese, contain compounds that exert beneficial effects on human health, such as conjugated linoleic acid (CLA) and gamma-aminobutyric acid (GABA) (Diana, Quilez, \& Rafecas, 2014; Sofi et al., 2010; Zlatanos, Laskaridis, Feist, \& Sagredos, 2002).

CLA is a group of positional and geometric isomers of octadecadienoic acid with a system of conjugated double bonds which have been attributed with several functional properties, including anti-carcinogenic, antiatherogenic, antiobesity effects and modulation of the immune system (Koba \& Yanagita, 2014; Tanaka, 2005).

CLA is naturally found in foods derived from ruminants because it occurs as an intermediary in biohydrogenation of polyunsaturated fatty acids, specifically of linoleic acid and a-linolenic acid, by the action of various anaerobic bacteria enzymes in the rumen. It is also synthesised in the mammary gland by the action of the $\Delta-9$ desaturase enzyme on vaccenic acid, which is another intermediary in ruminal biohydrogenation (RodriguezCastañedas, Peña-Egido, García-Marino, \& García-Moreno, 2011). This has prompted research to determine whether other bacteria involved in the fermentation of dairy products, are also capable of synthesising CLA. In recent years, several studies have shown that some lactic acid bacteria (LAB) and bifidobacteria strains can efficiently convert LA to CLA due to activity of the linoleate isomerase enzyme which has been observed to be strain-dependent (Coakley et al., 2003; Gorissen et al., 2011; Nieuwenhove, Oliszewski, González, \& Pérez Chaia, 2007a; Rodríguez-Alcalá, Braga, Malcata, Gomes, \& Fontecha, 2011).

GABA is a non-protein amino acid with numerous physiological functions, including neurotransmission, blood pressure regulation and insulin secretion (Adeghate \& Ponery, 2002; Diana et al., 2014; Okada et al., 2000). GABA is synthesised by glutamate decarboxylase (GAD), an enzyme dependent on pyridoxal 5'-phosphate, which catalyses adecarboxylation of L-glutamate or its salts to GABA (Narayan \& Nair, 1990). This enzyme has been found in LAB (Cotter \& Hill, 2003; Komatsuzi, Nakamura, Kimura, \& Shima, 2008), and thus a study of the capacity of LAB strains to produce GABA is of particular interest with a view to using them as starter cultures in the manufacture of fermented products. As Siragusa et al. (2007) have indicated, cheese is a good vehicle for GABA because milk caseins have a high content in L-glutamate $17.5 \%$ of the total amino acid content) which is released during cheese ripening and can be metabolised to GABA by the action of LAB (Hejtmánková, Pivec, Trnková, \& Dragounová, 2012).

However, the concentration of these compounds in cheese is generally under the minimum level required to play a beneficial role on human health. Information is lacking on CLA and GABA levels required by humans, but it is estimated that a daily intake of $3 \mathrm{~g}$ per day for a $70 \mathrm{~kg}$ person may be effective to achieve the beneficial effects of CLA and it has been pointed out that a daily oral administration of $26.4 \mathrm{mg}$ GABA is required to be effective in treating neurological disorders (Okada et al., 2000; Pariza, 2004).

It is therefore of interest to design natural strategies for enriching bioactive compound content in the final product. Several studies have indicated the possibility of modifying cheese composition by acting on the cheese manufacture process, and more particularly by using starter cultures with the capacity to synthesise CLA and GABA from 
linoleic acid (LA) and monosodium glutamate (MSG), respectively (Diana et al., 2014; Mohan, Anand, Kalscheur, Hassan, \& Hippen, 2013; Nieuwenhove, Oliszewski, González, \& Pérez Chaia, 2007b).

The objectives of this study were to: (i) screen 85 LAB strains isolated from artisanal cheeses for their capacity to synthesise CLA and GABA; (ii) test the biosynthesis of CLA and GABA under different incubation times; and (iii) detect the genes encoding linoleate isomerase and glutamate decarboxylase as a possible screening method. Therefore, this study was aimed to identify LAB strains capable of efficient production of CLA and GABA, for use in the design of starter cultures with the capacity to generate bioactive compounds, offering new possibilities for the manufacture of functional dairy products.

\section{MATERIALS AND METHODS}

\section{Strains and culture media}

For this study, 85 autochthonous LAB strains were selected for their adequate technological aptitude observed in previous studies and could potentially be considered as starter cultures for dairy products manufacture (González et al., 2007; González, Cuadrillero, Castro, Bernardo, \& Tornadijo, 2015; González, Sacristán, Arenas, Fresno, \& Tornadijo, 2010; Herreros, Fresno, González Prieto, \& Tornadijo, 2003). These strains were obtained from the collection held in the Department of Food Hygiene and Technology at the University of León (Table 1). All strains were screened for CLA and GABA production, and all experiments were carried out in duplicate. Before experimental use, the strains were subcultured twice in Elliker broth (BD Difco, New Jersey, USA) for Lactococcus lactis or in MRS broth (Oxoid, Hampshire, UK) for the remaining strains at $30^{\circ} \mathrm{C}$ during $24 \mathrm{~h}$. At this time of incubation, the growth phase of the strains studied was the initial stationary phase.

After subculture, the cultures were centrifuged at $20,800 \times g$ for $5 \mathrm{~min}$ at $4^{\circ} \mathrm{C}$ and the pellets were resuspended in a sterile physiological solution $(0.85 \% \mathrm{NaCl})$ until reaching an absorbance value between $1.0-1.3$ at a $550 \mathrm{~nm}$ wavelength, which corresponded to a cell density of 9.0 to $9.2 \log _{10} \mathrm{CFU} / \mathrm{mL}$.

\section{Screening for CLA producers}

Screening for strains capable of converting free LA to CLA was carried out following the method described by Barrett, Ross, Fitzgerald, and Stanton (2007), which is based on spectrophotometric detection of CLA, with some modifications. Briefly, the activated cultures were inoculated ( $5 \% \mathrm{v} / \mathrm{v})$ to the corresponding culture medium (Elliker or MRS) containing $0.5 \mathrm{mg} / \mathrm{mL}$ LA (99\% purity; $0.902 \mathrm{~g} / \mathrm{mL}$ density; Sigma-Aldrich, St. Louis, MO, USA). The LA was added as a $30 \mathrm{mg} / \mathrm{mL}$ stock solution containing $2 \%$ (v/v) Tween 80 (polyoxyethylene sorbitan mono-oleate; Merck-Schuchardt, Hohenbrunn, Germany) and was previously filter sterilized through a $0.45 \mu \mathrm{m}$ Minisart filter (Sartorius AG, Goettingen, Germany) and stored in the dark at $-20^{\circ} \mathrm{C}$ until use. The strains were incubated for $24 \mathrm{~h}$ and $48 \mathrm{~h}$ at $30^{\circ} \mathrm{C}$ to determine the effect of the incubation time for CLA production. Following incubation, the cultures were centrifuged at $20,800 \times g$ for $1 \mathrm{~min}$ at $4^{\circ} \mathrm{C}$, and the supernatants were mixed with $2 \mathrm{~mL}$ isopropanol and allowed to stand for $3 \mathrm{~min}$. Then, 1.5 $\mathrm{mL}$ of hexane was added and again allowed to stand for $3 \mathrm{~min}$. 
Table 1. List of the 85 autochthonous lactic acid bacteria strains screened in the present study isolated from Armada (TAUL), Genestoso (GE) and San Simón Da Costa (SS) cheeses and effect of the linoleic acid (LA) on their growth.

Lactococcus lactis subsp. lactis

GE 61, 118, 102, 103; TAUL 32, 238, 262,

250, 266; SS 194, 193

Lactococcus lactis subsp. cremoris

TAUL 1239, TAUL 216

Leuconostoc pseudomesenteroides

GE 2068; GE 2070

Leuconostoc mesenteroides

GE 2002; SS 1435, 1437, 1664

Lactobacillus brevis

TAUL 198, 1267, 141, 174, 67, 69, 70, 179,

195, 205

Lactobacillus casei

TAUL 171, 173, 175, 177, 180, 185, 190

Lactobacillus paracasei

GE 2036, 2071

Lactobacillus casei subsp. casei

TAUL 1506, 1508, 1699; SS 1614, 1615, 263

1644, 1661, 1694, 1689, 1770, 1778, 1785

Lactobacillus casei subsp. rhamnosus

SS 1684

Lactobacillus plantarum

GE 2077; TAUL 1736, 1765, 1521, 1522, 101,

$1539,1588,1795,38,39,52,55,122,125$,

194

Enterococcus italicus

TAUL 250; SS 194

Enterococcus faecalis

GE 26, 35, 2320, 2371, 2381; TAUL 117, 32,

262, 198; SS 193, 1378, 191, 1449

Enterococcus raffinosus

TAUL 1351

"The occurrence of growth inhibition of the cultures after addition of $0.5 \mathrm{mg} / \mathrm{ml}$ of LA. (-) growth was not inhibited, $(+)$ growth was retarded; $(++)$ strains were unable to continue growth after addition of LA to the cultures.

The amount of CLA synthetized was determined by measuring the absorbance at $233 \mathrm{~nm}$ using a 96-well plate spectrophotometer (BioTek Synergy HT spectrophotometer, Winooski, Vermont, USA).

To calculate the concentration of CLA produced by the LAB studied, a calibration curve was constructed for absorbance at $233 \mathrm{~nm}$ versus CLA (C18:2 c9,t11) ( $296 \%$ purity; Sigma-Aldrich, St. Louis, MO, USA) concentration $(0-30 \mu \mathrm{g} / \mathrm{mL})$, obtaining the equation: $\mathrm{y}=0.0654 \mathrm{x}+0.0085\left(\mathrm{R}^{2}=0.9994\right)$. 
Growth was monitored by measuring optical density at $600 \mathrm{~nm}$ (OD600) and cultures without LA were used as control to determine whether this compound inhibited growth of the bacteria studied.

The $\mathrm{pH}$ value of the culture medium was determined using a $\mathrm{pH}$ meter (Mettler Toledo, Columbus, Ohio, USA) equipped with a combined electrode at room temperature $\left(20 \pm 2^{\circ} \mathrm{C}\right)$.

\section{Screening for GABA producers}

The 85 strains were inoculated at $5 \%(\mathrm{v} / \mathrm{v})$ into the appropriate culture medium containing $5 \mathrm{mg} / \mathrm{mL}$ MSG (Sigma-Aldrich, St. Louis, MO, USA) and incubated for $72 \mathrm{~h}$ at $30^{\circ} \mathrm{C}$. Then, the strains identified as GABA producers were re-inoculated at $5 \%(\mathrm{v} / \mathrm{v})$ into the appropriate culture medium containing $5 \mathrm{mg} / \mathrm{mL}$ MSG and incubated for 24, 48 and $72 \mathrm{~h}$ at $30^{\circ} \mathrm{C}$ to determine the effect of incubation time on GABA production by the selected LAB. Detection of GABA-producing strains and quantification of GABA production at different incubation times was performed according to the method described by Barrett, Ross, O’Toole, Fitzgerald, and Stanton (2012).

\section{Linoleate isomerase, glutamate decarboxylase and glutamate-GABA antiporter gene}

Detection of genes encoding linoleate isomerase, glutamate decarboxylase and glutamate transporter was performed as follows: first, a search was conducted in the GenBank database for all genes of the same species encoding the corresponding enzyme. The sequences available for each species were aligned to identify highly conserved regions, which enabled the design of the primers (Sigma-Aldrich, St. Louis, MO, USA) (Table 2). The primers $(0.4 \mu \mathrm{M}$ each) were used to amplify the respective target sequences from the genomic DNA $(0.1 \mathrm{ng})$ of the selected bacteria. The amplification reaction $(50 \mu \mathrm{L})$ was performed using BioMix RedTM (Bioline) in an Applied Biosystems 2720 Thermal Cycler (Life Technologies). PCR cycles $\left(95^{\circ} \mathrm{C}, 1 \mathrm{~min} ; 55^{\circ} \mathrm{C}, 60 \mathrm{~s} ; 72^{\circ} \mathrm{C}, 90 \mathrm{~s}\right)$ were preceded by a denaturation step $\left(95^{\circ} \mathrm{C}, 5 \mathrm{~min}\right)$ and concluded with a final elongation step $\left(70^{\circ} \mathrm{C}, 7 \mathrm{~min}\right)$.

Table 2. Primers used in this study for the detection of the genes encoding the enzymes linoleate isomerase (lis), glutamate decarboxylase $(\mathrm{gadB})$ and glutamate transporter (gadC) involved in CLA and GABA biosynthesis.

\begin{tabular}{|c|c|c|c|}
\hline Primer & Sequence (5’-3') & Gene & $\begin{array}{l}\text { Expected } \\
\text { size }\end{array}$ \\
\hline Lbcasf & GATCAAGCATAAGGCGATCATGATCGG & lis (L. casei) & $600 \mathrm{bp}$ \\
\hline Lbcasr & TAAATCATCATGTGCATGTACCGCCG & & \\
\hline Lbplf & GCAATTATGATTGGTGCCGG & lis (L. plantarum) & $450 \mathrm{bp}$ \\
\hline Lbplr & CTTCGTTTCTTCACTATCTGGCATC & & \\
\hline lacBf & TCTGTCAAACTTATATGGAACCTGAAGC & $\operatorname{gadB}($ L. lactis) & $1100 \mathrm{bp}$ \\
\hline lacBr & CTTGAACATAGTTAAATGCCATATTCATCCC & & \\
\hline lacCf & GCCACGTCAAAATTACATTTGGTGTTCT & gadC (L. lactis) & $1000 \mathrm{bp}$ \\
\hline lacCr & ССТССТССТССАAAAGTTAATACAGCGCССС & & \\
\hline brevB1f & AGGCAGTGTCGAAGCCGGGCAA & gadB1 (L. brevis) & $1300 \mathrm{bp}$ \\
\hline brevB1r & CATGGATGGGCGTACCACGATCC & & \\
\hline brevB2f & CTCGCCACGTTCTGTCAGACTTACATGG & gadB2 (L. brevis) & $1100 \mathrm{bp}$ \\
\hline brevB2r & TCATCAATAAAGTCGTGGGCCATACTCATACC & & \\
\hline brevCf & CCATGACGACTTCCATGGTCATGACGGTT & $\operatorname{gadC}($ L. brevis) & $1300 \mathrm{bp}$ \\
\hline brevCr & GCATGACCACAAAGGCACTCACTAACAACA & & \\
\hline
\end{tabular}

Next, PCR products were separated by electrophoresis on $1 \%$ (wt/vol) agarose gel (Thermo Fisher Scientific, Waltham, Massachusetts). A DNA molecular marker was loaded 
in parallel in the gel to predict the estimated size of the PCR products. Gels were stained with $0.5 \mu \mathrm{g} / \mathrm{mL}$ ethidium bromide (Sigma-Aldrich, St. Louis, MO, USA) and then imaged under ultraviolet light in an Alpha ImagerTM 3400 (Alpha Innotech, Kasendorf, GmbH).

\section{Statistical analysis}

All experimental data obtained in the study of CLA and GABA production by LAB at different incubation times were statistically analysed using SPSS v.21 (SPSS, Chicago, IL, USA). The variables studied were tested for the assumptions of normality and homoscedasticity. Subsequently, we performed a one-way analysis of variance (ANOVA) and then applied Tukey's HSD post hoc test at a 5\% significance level.

\section{RESULTS AND DISCUSSION}

In this study, first of all the tolerance of the strains to LA was tested in MRS or Elliker broth, since several studies have reported that LA can retard or inhibit the growth of some bacteria (Gorissen et al., 2010; Jiang, Björck, \& Fondén, 1998; Nieuwenhove et al., 2007a). The concentration of LA used in this study was based on the concentration $(0.5$ $\mathrm{mg} / \mathrm{mL}$ ) of this fatty acid in sheep's milk (De La Fuente et al., 2009), which would mean that the CLA-producing strains could grow in sheep milk.

Of the 85 strains tested, only 6 strains showed inhibited growth and one did not grow after $48 \mathrm{~h}$ incubation (Table 1), which was in agreement with the antimicrobial effect of free LA on LAB (Alonso, Cuesta, \& Gilliland, 2003). These results confirm that inhibition of LAB growth by LA is strain- and not species-dependent, as has also been reported by Gorissen et al. (2010) in their study of Bifidobacterium species.

Determination of CLA production by bacteria is usually performed by fat extraction and methylation of fatty acids followed by gas chromatography analysis. El-Salam, ElShafei, Sharaf, Effat, and El-Aasar (2010) have reported that although this method gives good results, it is time consuming and requires expensive equipment. Consequently, we decided to use a method based on spectrophotometric measurement of the conjugated double bond in the fatty acids, which is a less expensive and time consuming technique. This method offers advantages when screening a large number of samples, as was the case in this study.

Of all the strains tested, only 2 L. casei subsp. casei and 4 L. plantarum strains were capable of synthesising CLA from free LA (Table 3). Lactobacillus are non-starter lactic acid bacteria (NSLAB) which play a role in cheese ripening, and thus their study as a potential co-culture is of particular interest.

Several studies have reported that the CLA concentration produced by LAB strains can be affected by various factors, including incubation time and $\mathrm{pH}$ (El-Salam et al., 2010; Rodríguez-Alcalá et al., 2011). Mean CLA production by bacteria at different incubation times was calculated using the calibration curve described above. All strains showed a statistically significant increase $(P \leq 0.001)$ in CLA synthesis from $24 \mathrm{~h}$ to $48 \mathrm{~h}$ incubation, indicating that incubation time is an important factor to consider in CLA production by Lactobacillus strains (Table 3). L. plantarum TAUL 1588 strain produced the most CLA after $24 \mathrm{~h}$ and $48 \mathrm{~h}$ incubation, yielding values similar to those reported by Rodríguez-Alcalá et al. (2011) for a strain of the same species, using the same method and 
by Terán et al. (2015) using the gas chromatography analysis. This strain is therefore of great interest due to its high rate of CLA production which opens the opportunity to study this autochthonous strain as a co-culture for the possible development of functional dairy products.

Table 3. CLA strains producers in this study and CLA concentration ${ }^{\mathrm{a}}$ detected in the culture medium ${ }^{\mathrm{b}}$ for 24 and 48 hours of incubation.

\section{Strain}

24

Lactobacillus casei casei SS 1644

Lactobacillus casei casei SS 1614

Lactobacillus plantarum TAUL 1522

Lactobacillus plantarum TAUL 1539

Lactobacillus plantarum TAUL 1588

Lactobacillus plantarum TAUL 1795

$2.43(5.05)$
$3.01(2.63)$
$4.88(2.13)$
$7.52(1.28)$

$10.50(2.80)$

3.89 (2.00)
48

$6.51(3.14)$
$6.40(1.42)$
$6.74(2.73)$
$13.52(2.31)$
$19.26(2.07)$

Time effect

aResults as mean values of duplicate determination expressed as $\mu \mathrm{g} / \mathrm{mL}$ (coefficient of variation, RSD).

${ }^{b}$ CLA concentration in $\mu \mathrm{g} / \mathrm{ml}$ of MRS medium with free LA $(0.5 \mathrm{mg} / \mathrm{mL})$ for $24 \mathrm{~h}$ and for $48 \mathrm{~h}$ calculated spectrophotometrically at wavelength of $233 \mathrm{~nm}$ from the linear trend of the standard curve. $* * * P \leq 0.001$.

L. casei subsp. casei SS 1644 was the strain that produced the lowest concentration of CLA at $24 \mathrm{~h}$ incubation, while $L$. casei subsp. casei SS 1614 produced the lowest concentration at $48 \mathrm{~h}$. In general, L. casei subsp. casei was less efficient at producing CLA than L. plantarum. Although some authors have indicated that the ability of LAB to produce CLA is strain-dependent, these results suggest the need to continue studying the pathway and mechanism of CLA production by LAB.

The initial $\mathrm{pH}$ of the culture medium (5.92 - 6.12) decreased to values of $3.85-4.00$ at $24 \mathrm{~h}$ and remained at that level or decreased slightly after $48 \mathrm{~h}$ incubation. The $L$. plantarum TAUL 1539 and TAUL 1588 strains produced the greatest drop in the $\mathrm{pH}$ medium after $24 \mathrm{~h}$ and $48 \mathrm{~h}$, and also produced the highest CLA concentration at these incubation times.

It should be borne in mind that the spectrophotometric method employed does not detect the different CLA isomers (Barrett et al., 2007), which would be of interest since the properties beneficial to human health are mainly related to two CLA isomers: cis-9, trans$11 \mathrm{C}_{18: 2}$ and trans-10,cis-12 $\mathrm{C}_{18: 2}$. In addition, the trans-9,trans-11 $\mathrm{C}_{18: 2}$ isomer is being studied because of its potential anti-carcinogenic effects on human colon cancer cell lines (Coakley et al., 2006), and its capacity to induce the expression of genes involved in lipid metabolism (Ecker, Liebisch, Patsch, \& Schmitz, 2009). For this reason and for the good capacity of the studied Lactobacillus strains to produce CLA, it would be of interest to conduct further and more specific studies on these autochthonous LAB strains.

The presence of the gene encoding linoleate isomerase in the CLA-producing strains was identified in this study (Figure 1). Linoleate isomerase is the enzyme responsible for the production of CLA from LA as a substrate in LAB (Chen, 2012; Gorissen et al., 2011). PCR products were detected as a single band. In the case of the L. plantarum strains, the approximate size of the detected band was $500 \mathrm{bp}$, while in case of the two L. casei subp. casei strains, it was $600 \mathrm{bp}$. This gene was also detected in some of the strains that did not produce CLA (Figure 2), indicating that the presence of a gene does not imply the 
production of the relative compound. Therefore, strains should be genetically characterized at first and then evaluated for the production. The non-production of CLA in strains containing the gene can be explained according to Gorissen et al. (2011), because the linoleate isomerase gene may be present in the strains, but its expression can be affected by various factors, such as $\mathrm{pH}$ or temperature, and these effects are in turn straindependent.

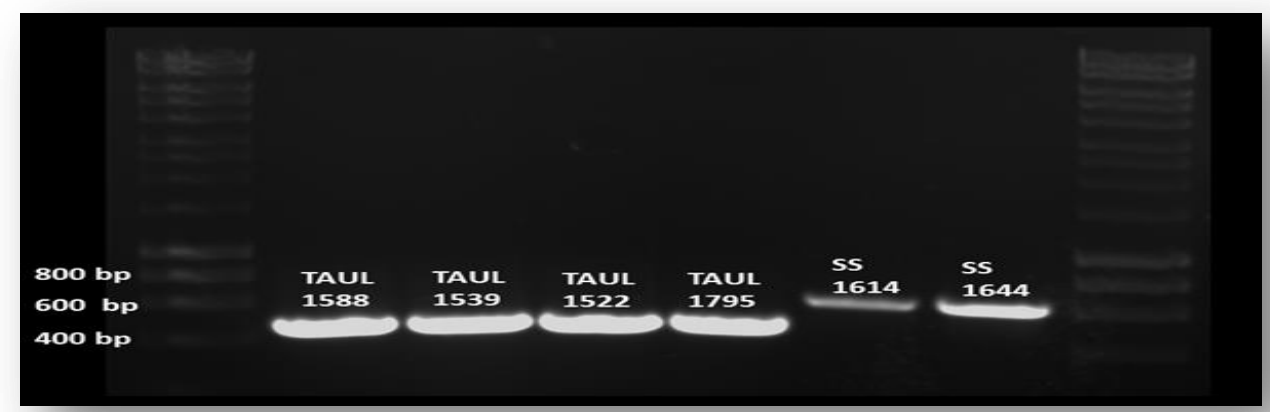

Figure 1. Linoleate isomerase gene detection of the strains selected as CLA producers.

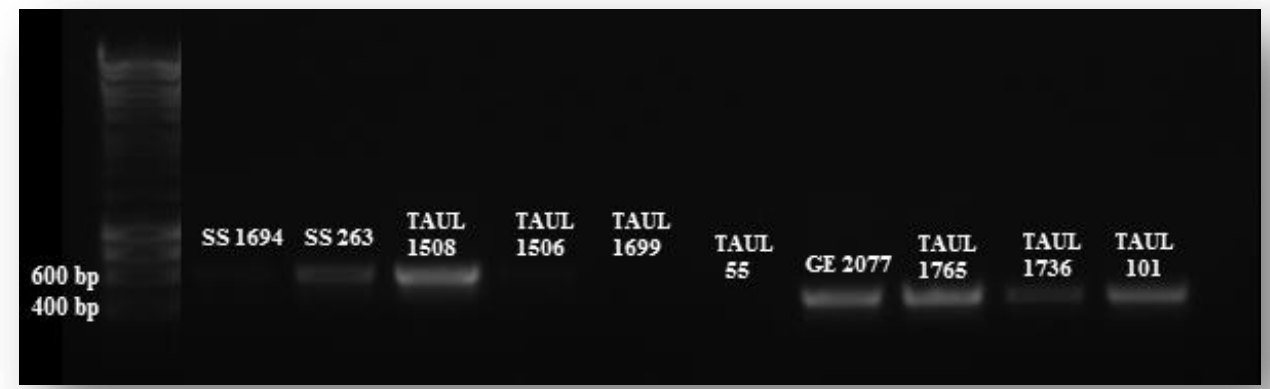

Figure 2. Linoleate isomerase gene detection of some no CLA producing-strains.

None of the CLA-producing strains produced GABA, and vice versa. This fact opens new perspectives for the study of the existence of possible mechanisms that may interfere in the joint production of CLA and GABA by LAB.

Ten of the 85 strains studied were identified as GABA producers (Table 4). These strains were: L. lactis subp. lactis (GE 61, GE 118, GE 102, GE 103) and L. brevis (TAUL 141, TAUL 174, TAUL 69, TAUL 70, TAUL 179, TAUL 195). These results indicate the variability between strains of the same species and confirm that the capacity to synthesise GABA is strain-dependent, as indicated by Siragusa et al. (2007).

Dhakal, Bajpai, and Baek (2012)have reported that different fermentation factors, including incubation time, can affect GABA synthesis by microorganisms. Table 4 shows 
the evolution of GABA production by the strains studied over various incubation times in culture medium supplemented with MSG. All strains showed a statistically significant increase in GABA synthesis $(P \leq 0.05)$ from $24 \mathrm{~h}$ to $72 \mathrm{~h}$ incubation. This is in agreement with a study by Wu and Shah (2015), who reported an increase in GABA production by 9 LAB strains after $72 \mathrm{~h}$ incubation in MRS medium supplemented with $50 \mathrm{mg} / \mathrm{mL}$ of MSG as substrate.

Table 4. GABA strains producers in this study and GABA concentrationa detected in the culture medium $^{\mathrm{b}}$ for 24,48 and 72 hours of incubation.

\begin{tabular}{lcccc} 
Strain & $\mathbf{2 4}$ & $\mathbf{4 8}$ & $\mathbf{7 2}$ & $\begin{array}{c}\text { Time } \\
\text { effect }\end{array}$ \\
\hline Lactococcus lactis lactis GE 61 & $280.51(3.20)$ & $468.66(1.07)$ & $668.10(1.48)$ & $* * *$ \\
Lactococcus lactis lactis GE 118 & $245.05(2.43)$ & $282.02(3.74)$ & $516.87(1.97)$ & $* * *$ \\
Lactococcus lactis lactis GE 102 & $95.44(4.62)$ & $279.04(1.71)$ & $573.74(1.49)$ & $* * *$ \\
Lactococcus lactis lactis GE 103 & $267.16(7.44)$ & $678.33(1.68)$ & $766.38(2.78)$ & $* * *$ \\
Lactobacillus brevis TAUL 141 & $1350.36(2.32)$ & $1378.04(0.31)$ & $2492.51(2.54)$ & $* * *$ \\
Lactobacillus brevis TAUL 174 & $1046.78(2.43)$ & $1161.06(3.69)$ & $1820.25(1.64)$ & $* * *$ \\
Lactobacillus brevis TAUL 69 & $927.52(1.22)$ & $1024.15(2.29)$ & $1306.85(6.42)$ & $* *$ \\
Lactobacillus brevis TAUL 70 & $1949.82(3.05)$ & $2068.50(0.65)$ & $2442.74(0.90)$ & $* *$ \\
Lactobacillus brevis TAUL 179 & $1819.85(4.77)$ & $2112.66(4.98)$ & $2310.63(7.69)$ & $* *$ \\
Lactobacillus brevis TAUL 195 & $2003.71(2.19)$ & $2333.07(3.80)$ & $2524.05(8.83)$ & $* *$
\end{tabular}

aResults as mean values of duplicate determination expressed as $\mu \mathrm{g} / \mathrm{mL}$ (coefficient of variation, RSD).

bGABA concentration in $\mu \mathrm{g} / \mathrm{ml}$ of MRS or Elliker broth with monosodium glutamate $(5 \mathrm{mg} / \mathrm{mL})$ for 24 , 48 and $72 \mathrm{~h}$.

${ }^{* *} P \leq 0.01 ;{ }^{* *} P \leq 0.001$.

The strain that produced the highest GABA concentration was L. brevis TAUL 195 after $72 \mathrm{~h}$ incubation, synthesizing $2524.05 \mu \mathrm{g} / \mathrm{mL}$, which makes it a very interesting autochthonous strain to be used as a co-culture.

These findings indicate that the L. brevis strains were more efficient at producing GABA than L. lactis strains, coinciding with the results reported in other studies (Barrett et al., 2012; Zhang et al., 2012).

The glutamate decarboxylase system, which is composed of GAD and the glutamate - GABA antiporter, is responsible for the production of GABA in LAB ( $\mathrm{Li}, \mathrm{Li}, \mathrm{Liu}, \&$ Cao, 2013). In this study, we also tested the presence of the genes encoding the GAD enzyme and the glutamate - GABA antiporter in GABA-producing and in GABA-not producing strains (Figures 3 and 4).

The presence of both genes was detected only in the four GABA-producers L. lactis strains (Figure 3). These results highlight the possibility of using this technique as a method for screening of $L$. lactis GABA- producing strains based on the presence of these genes, although this should be studied in a larger number of strains.

Nomura et al. (1999) noted that $L$. lactis contains only one glutamate decarboxylase gene, as was observed in our study. However, in L. brevis, two different GAD encoding genes were detected as $\mathrm{Li}$ et al. (2013) indicated. The three genes encoding the glutamate decarboxylase system were detected in all the GABA- producer L. brevis (Figure 4). 


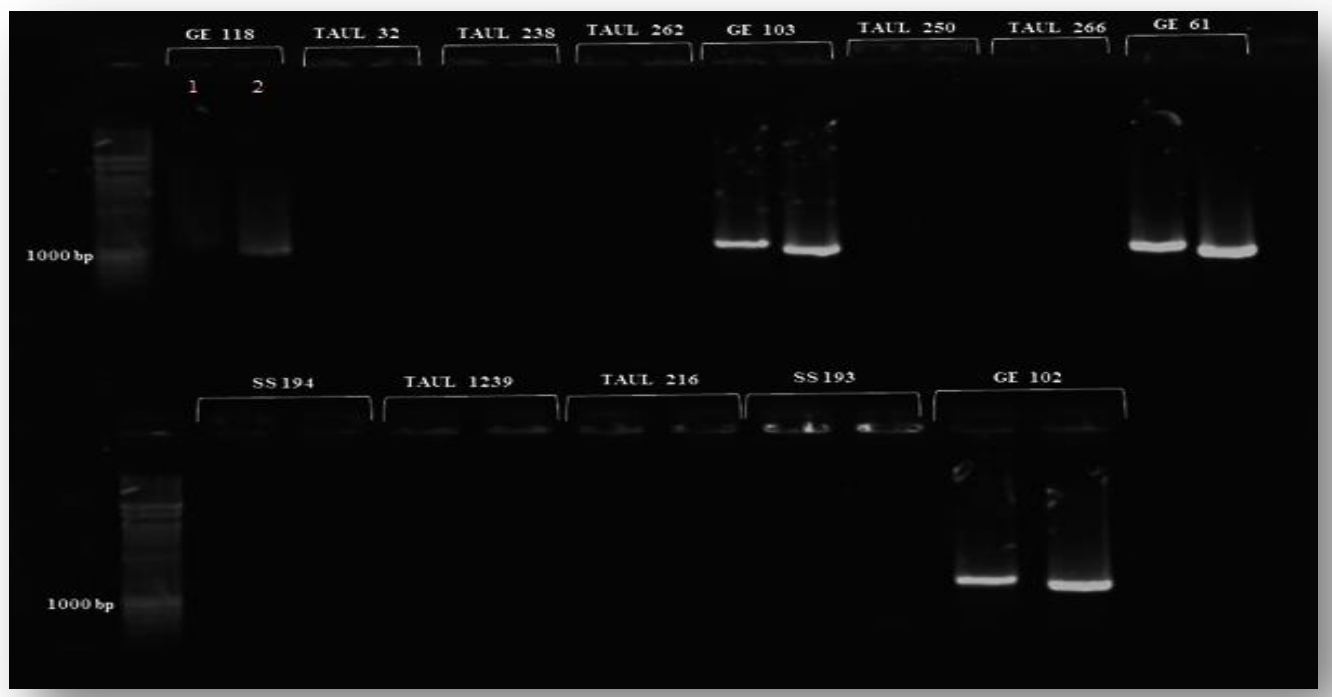

Figure 3. Glutamate decarboxylase and glutamate-GABA antiporter genes detection of Lactococcus lactis strains.(1) gene 1 encoding glutamate decarboxylase; (2) gene encoding glutamate-GABA antiporter.

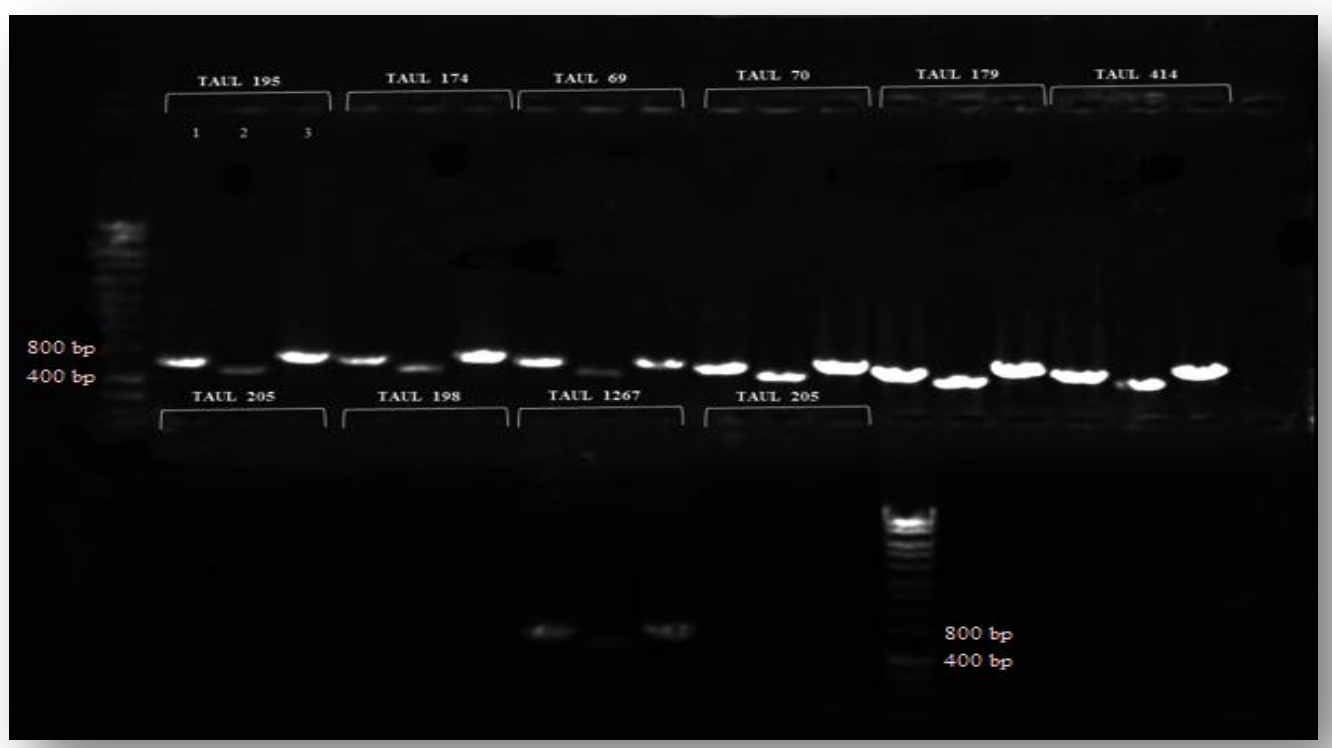

Figure 4. Glutamate decarboxylase and glutamate-GABA antiporter genes detection of Lactobacillus brevis strains.(1) gene 1 encoding glutamate decarboxylase; (2) gene 2 encoding glutamate decarboxylase; (3) gene encoding glutamate-GABA antiporter.

\section{CONCLUSIONS}

Considering the health benefits of CLA and GABA, the good ability of the studied autochthonous strains (L. plantarum TAUL 1588 and L. brevis TAUL 195) to produce these 
bioactive compounds, could contribute to the development of starters that can be used in the manufacture of functional dairy products.

To the best of our knowledge, this is the first study to report the importance of the presence of genes to screen CLA and GABA producer-strains. This fact also opens the way for further studies to understand the mechanisms involved in the production of these bioactive compounds by LAB.

\section{ACKNOWLEDGMENTS}

The authors are grateful to the University of León (León, Spain) for granting a PhD fellowship to Erica Renes Bañuelos.

\section{REFERENCES}

Adeghate, E., \& Ponery, A. S. (2002). GABA in the endocrine pancreas: cellular localization and function in normal and diabetic rats. Tissue and Cell, 34(1), 1-6.

Alonso, L., Cuesta, E. P., \& Gilliland, S. E. (2003). Production of free conjugated linoleic acid by Lactobacillus acidophilus and Lactobacillus casei of human intestinal origin. Journal of Dairy Science, 86(6), 1941-1946.

Barrett, E., Ross, R. P., Fitzgerald, G. F., \& Stanton, C. (2007). Rapid screening method for analyzing the conjugated linoleic acid production capabilities of bacterial cultures. Applied and Environmental Microbiology, 73(7), 2333-2337.

Barrett, E., Ross, R. P., OToole, P. W., Fitzgerald, G. F., \& Stanton, C. (2012). YAminobutyric acid production by culturable bacteria from the human intestine. Journal of Applied Microbiology, 113(2), 411-417.

Chen, W. (2012). Purification and characterization of a linoleate isomerase from Lactobacillus plantarum ZS2058. African Journal of Biotechnology, 11(20), 45794587.

Coakley, M., Johnson, M. C., McGrath, E., Rahman, S., Ross, R. P., Fitzgerald, G. F., ... Stanton, C. (2006). Intestinal bifidobacteria that produce trans-9, trans-11 Conjugated Linoleic Acid: A fatty acid with antiproliferative activity against human colon SW480 and HT-29 cancer cells. Nutrition and Cancer, 56(1), 95-102.

Coakley, M., Ross, R. P., Nordgren, M., Fitzgerald, G., Devery, R., \& Stanton, C. (2003). Conjugated linoleic acid biosynthesis by human-derived Bifidobacterium species. Journal of Applied Microbiology, 94(1), 138-145.

Cotter, P. D., \& Hill, C. (2003). Surviving the acid test: responses of gram-positive bacteria to low pH. Microbiology and Molecular Biology Reviews, 67(3), 429-453.

De La Fuente, L. F., Barbosa, E., Carriedo, J. A., Gonzalo, C., Arenas, R., Fresno, J. M., \& San Primitivo, F. (2009). Factors influencing variation of fatty acid content in ovine milk. Journal of Dairy Science, 92(8), 3791-3799.

Dhakal, R., Bajpai, V. K., \& Baek, K. H. (2012). Production of gaba (gamma-aminobutyric acid) by microorganisms: a review. Brazilian Journal of Microbiology, 43(4), 12301241.

Diana, M., Quílez, J., \& Rafecas, M. (2014). Gamma-aminobutyric acid as a bioactive compound in foods: a review. Journal of Functional Foods, 10, 407-420. 
Ecker, J., Liebisch, G., Patsch, W., \& Schmitz, G. (2009). The conjugated linoleic acid isomer trans-9,trans-11 is a dietary occurring agonist of liver $\mathrm{X}$ receptor a. Biochemical and Biophysical Research Communications, 388(4), 660-666.

El-Salam, M. H. A., El-Shafei, K., Sharaf, O. M., Effat, B. A., \& El-Aasar, M. (2010). Screening of some potentially probiotic lactic acid bacteria for their ability to synthesis conjugated linoleic acid. International Journal of Dairy Technology, 63(1), 62-69.

González, L., Cuadrillero, A., Castro, J. M., Bernardo, A., \& Tornadijo, M. E. (2015). Selection of lactic acid bacteria isolated from San Simón da Costa Cheese (PDO) in order to develop an autochthonous starter culture. Advances in Microbiology, 5(5), 748-759.

González, L., Sacristán, N., Arenas, R., Fresno, J. M., \& Tornadijo, M. E. (2010). Enzymatic activity of lactic acid bacteria (with antimicrobial properties) isolated from a traditional Spanish cheese. Food Microbiology, 27(5), 592-597.

González, L., Sandoval, H., Sacristán, N., Castro, J. M., Fresno, J. M., \& Tornadijo, M. E. (2007). Identification of lactic acid bacteria isolated from Genestoso cheese throughout ripening and study of their antimicrobial activity. Food Control, 18(6), 716-722.

Gorissen, L., Raes, K., Weckx, S., Dannenberger, D., Leroy, F., De Vuyst, L., \& De Smet, S. (2010). Production of conjugated linoleic acid and conjugated linolenic acid isomers by Bifidobacterium species. Applied Microbiology and Biotechnology, 87(6), 22572266.

Gorissen, L., Weckx, S., Vlaeminck, B., Raes, K., De Vuyst, L., De Smet, S., \& Leroy, F. (2011). Linoleate isomerase activity occurs in lactic acid bacteria strains and is affected by $\mathrm{pH}$ and temperature. Journal of Applied Microbiology, 111(3), 593-606.

Hejtmánková, A., Pivec, V., Trnková, E., \& Dragounová, H. (2012). Differences in the composition of total and whey proteins in goat and ewe milk and their changes throughout the lactation period. Czech Journal of Animal Science, 57(7), 323-331.

Herreros, M. ., Fresno, J. M., González Prieto, M. J., \& Tornadijo, M. E. (2003). Technological characterization of lactic acid bacteria isolated from Armada cheese (a Spanish goats' milk cheese). International Dairy Journal, 13(6), 469-479.

Jiang, J., Björck, L., \& Fondén, R. (1998). Production of conjugated linoleic acid by dairy starter cultures. Journal of Applied Microbiology, 85(1), 95-102.

Koba, K., \& Yanagita, T. (2014). Health benefits of conjugated linoleic acid (CLA). Obesity Research \& Clinical Practice, 8(6), 525-532.

Komatsuzi, N., Nakamura, T., Kimura, T., \& Shima, J. (2008). Characterization of glutamate decarboxylase from a high $\gamma$-aminobutyric acid (GABA)-producer, Lactobacillus paracasei. Bioscience, Biotechnology, and Biochemistry, 72(2), 278-285.

Li, H., Li, W., Liu, X., \& Cao, Y. (2013). gadA gene locus in Lactobacillus brevis NCL912 and its expression during fed-batch fermentation. FEMS Microbiology Letters, 349(2), 108116.

Mohan, M. S., Anand, S., Kalscheur, K. F., Hassan, A. N., \& Hippen, A. R. (2013). Starter cultures and cattle feed manipulation enhance conjugated linoleic acid concentrations in Cheddar cheese. Journal of Dairy Science, 96(4), 2081-2094.

Narayan, V. S., \& Nair, P. M. (1990). Metabolism, enzymology and possible roles of 4- 
aminobutyrate in higher plants. Phytochemistry, 29(2), 367-375.

Nieuwenhove, V. C. P., Oliszewski, R., González, S. N., \& Pérez Chaia, A. B. (2007a). Conjugated linoleic acid conversion by dairy bacteria cultured in MRS broth and buffalo milk. Letters in Applied Microbiology, 44(5), 467-474.

Nieuwenhove, V. C. P., Oliszewski, R., González, S. N., \& Pérez Chaia, A. B. (2007b). Influence of bacteria used as adjunct culture and sunflower oil addition on conjugated linoleic acid content in buffalo cheese. Food Research International, 40(5), 559-564.

Nomura, M., Nakajima, I., Fujita, Y., Kobayashi, M., Kimoto, H., Suzuki, I., \& Aso, H. (1999). Lactococcus lactis contains only one glutamate decarboxylase gene. Microbiology, 145(6), 1375-1380.

Okada, T., Sugishita, T., Murakami, T., Murai, H., Saikusa, T., Horino, T., ... Takahashi, T. (2000). Effect of the defatted rice germ enriched with GABA for sleeplessness, depression, autonomic disorder by oral administration. Journal of the Japanese Society for Food Science and Technology, 47(8), 596-603.

Pariza, M. W. (2004). Perspective on the safety and effectiveness of conjugated linoleic acid. The American Journal of Cinical Nutrition, 79(6), 1132-1136.

Rodríguez-Alcalá, L. M., Braga, T., Malcata, X. F., Gomes, A., \& Fontecha, J. (2011). Quantitative and qualitative determination of CLA produced by Bifidobacterium and lactic acid bacteria by combining spectrophotometric and Ag+-HPLC techniques. Food Chemistry, 125(4), 1373-1378.

Rodríguez-Castañedas, J. L., Peña-Egido, M. J., García-Marino, M., \& García-Moreno, C. (2011). Quantitative determination of conjugated linoleic acid isomers by silver ion HPLC in ewe milk fat. Journal of Food Composition and Analysis, 24(7), 1004-1008.

Siragusa, S., De Angelis, M., Di Cagno, R., Rizzello, C. G., Coda, R., \& Gobbetti, M. (2007). Synthesis of gamma-aminobutyric acid by lactic acid bacteria isolated from a variety of Italian cheeses. Applied and Environmental Microbiology, 73(22), 7283-90.

Sofi, F., Buccioni, A., Cesari, F., Gori, A. M., Minieri, S., Mannini, L., ... Antongiovanni, M. (2010). Effects of a dairy product (pecorino cheese) naturally rich in cis-9, trans-11 conjugated linoleic acid on lipid, inflammatory and haemorheological variables: A dietary intervention study. Nutrition, Metabolism and Cardiovascular Diseases, 20(2), $117-124$.

Tanaka, K. (2005). Occurrence of conjugated linoleic acid in ruminant products and its physiological functions. Animal Science Journal, 76(4), 291-303.

Terán, V., Pizarro, P. L., Zacarías, M. F., Vinderola, G., Medina, R., \& Van Nieuwenhove, C. (2015). Production of conjugated dienoic and trienoic fatty acids by lactic acid bacteria and bifidobacteria. Journal of Functional Foods, 19(Part A), 417-425.

Wu, Q., \& Shah, N. P. (2015). Gas release-based prescreening combined with reversedphase HPLC quantitation for efficient selection of high- $\gamma$-aminobutyric acid (GABA)producing lactic acid bacteria. Journal of Dairy Science, 98(2), 790-797.

Zhang, Y., Song, L., Gao, Q., Yu, S. M., Li, L., \& Gao, N. F. (2012). The two-step biotransformation of monosodium glutamate to GABA by Lactobacillus brevis growing and resting cells. Applied Microbiology and Biotechnology, 94(6), 1619-1627.

Zlatanos, S., Laskaridis, K., Feist, C., \& Sagredos, A. (2002). CLA content and fatty acid composition of Greek Feta and hard cheeses. Food Chemistry, 78(4), 471-477. 


\title{
CAPÍTULO 3
}

\section{Study of the conjugated linoleic acid synthesis by Lactobacillus strains and by different co-cultures designed for this ability}

\author{
Erica Renes ${ }^{1}$, Daniel M. Linares², Leticia González' ${ }^{1}$, José Maria Fresno ${ }^{1}$, \\ Maria Eugenia Tornadijo ${ }^{1}$ and Catherine Stanton ${ }^{2}$ \\ ${ }^{1}$ Department of Food Hygiene and Technology, University of León, Spain. 2Department of \\ Food Biosciences, Teagasc Food Research Centre, Moorepark, Ireland.
}

Journal of Functional Foods, 2017, 35, 74-80

Abstract

Consumer concern about the relationship between food and health has generated a growing interest in functional foods. Conjugated linoleic acid (CLA) has been associated with several beneficial health properties. Therefore, this study reports the design of cocultures containing CLA-producing strains and their performance in MRS and in skim milk.

The four designed co-cultures were tested under different conditions. In MRS, co-culture 2 (containing autochthonous Lactococcus lactis strains and Lactobacillus plantarum TAUL 1588) was the highest CLA-producer $(98.01 \mu \mathrm{g} / \mathrm{mL})$ after $48 \mathrm{~h}$ incubation. In milk, the highest total CLA production $(56.51 \mu \mathrm{g} / \mathrm{mL}$ ) was reached with co-culture 4 (containing autochthonous Lactococcus lactis, Lactobacillus plantarum TAUL 1588 and Lactobacillus casei SS 1644) after $72 \mathrm{~h}$.

These results open the way for the use of co-cultures containing CLA-producing strains to manufacture cheese and obtain functional dairy products rich in bioactive fatty acids. 



\section{INTRODUCTION}

Conjugated linoleic acid (CLA) consists of a group of positional and geometric isomers of octadecadienoic acid with a system of conjugated double bonds which have been associated with several properties that are beneficial for human health, such as: anticarcinogenic, antiatherogenic and antiobesity effects and modulation of the immune system (Coakley et al., 2006; Ecker, Liebisch, Patsch, \& Schmitz, 2009; Kim et al., 2016; Yang et al., 2015). The main CLA isomers attributed with these beneficial properties are

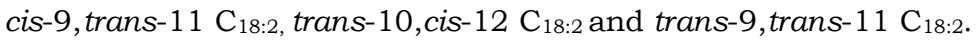

CLA is naturally found in foods derived from ruminants because it is produced as an intermediary in biohydrogenation of polyunsaturated fatty acids, by the action of the enzymes of various anaerobic bacteria in the rumen. It is also synthesised in the mammary gland by the action of the $\Delta-9$ desaturase enzyme on vaccenic acid, which is another intermediary in ruminal biohydrogenation (Rodríguez-Castañedas, Peña-Egido, GarcíaMarino, \& García-Moreno, 2011). CLA content in milk and dairy products ranges between $0.68 \%$ and $0.12 \%$ of total fat (Luna, Juárez, \& de la Fuente, 2007). At present, the estimated human intake of CLA from food sources is insufficient to obtain the potential effects against cancer, atherosclerosis and obesity reported in studies on animal models (Watkins \& Li, 2003). Such effects would require a much higher consumption of milk and dairy products than the normal intake provided in a standard diet. Consequently, various methods are being explored to increase the content of this beneficial compound in fermented dairy products, being the use of starter cultures containing CLA-producing strains during manufacture as a the possible strategies (Andrade et al., 2012). Some studies have examined the capacity of certain lactic acid bacteria (LAB) and bifidobacteria to synthesise CLA from linoleic acid (LA) as substrate, finding that various strains are capable of producing significant amounts of CLA (Alonso, Cuesta, \& Gilliland, 2003; Gorissen et al., 2010). However, there is no knowledge about the design of co-cultures which could produce CLA in culture medium or skim milk supplemented with LA during different incubation times, in order to know the optimal conditions for CLA production.

The objectives of this study were to: (i) quantify CLA production by LAB in culture medium and in skim milk supplemented with free LA at different incubation times; (ii) design co-cultures containing CLA-producing strains; and (iii) quantify CLA production by those co-cultures in the synthetic medium and in skim milk supplemented with free LA at different incubation times. Consequently, the overall aim of the present study was to obtain co-cultures that not only contributed actively to cheese ripening, but were also capable of generating bioactive compounds, thus increasing CLA content in cheese and could obtain functional dairy foods.

\section{MATERIALS AND METHODS}

\section{Strains, co-cultures, media and growth conditions for CLA production}

In a previous study, of the 85 strains isolated from three traditional Spanish cheeses (Armada cheese, Genestoso cheese and San Simon da Costa cheese) and technologically characterized (González, Cuadrillero, Castro, Bernardo, \& Tornadijo, 2015; Herreros, Fresno, González Prieto, \& Tornadijo, 2003) only six autochthonous LAB strains 
showed the capacity to synthesize CLA. In this previous study, the screening of the strains capable of converting free LA to CLA was carried out following the method described by Barrett, Ross, Fitzgerald, and Stanton (2007), which is based on spectrophotometric detection of CLA. These six strains were selected for this study and were: Lactobacillus plantarum TAUL 1539, TAUL 1588, TAUL 1795 and TAUL 1522, and Lactobacillus casei subsp. casei SS 1614 and SS 1644. Prior to examination of CLA production, each strain was subcultured twice at $30^{\circ} \mathrm{C}$ for $24 \mathrm{~h}$ in MRS broth (Oxoid, Hampshire, UK) for Lactobacillus or in M17 broth (BD Difco, New Jersey, USA) for Lactococcus lactis. These activated cultures were transferred at $5 \%(\mathrm{v} / \mathrm{v})$ to MRS broth and reconstituted skim milk at $10 \%(\mathrm{w} / \mathrm{v})$ in deionised water containing $0.5 \mathrm{mg} / \mathrm{mL}$ of LA (Sigma, St. Louis, MO, USA). The LA was added as a $30 \mathrm{mg} / \mathrm{mL}$ stock solution containing $2 \%$ (v/v) Tween 80 (polyoxyethylene sorbitan mono-oleate; Merck-Schuchardt, Hohenbrunn, Germany) and was previously filter sterilized through a $0.45 \mu \mathrm{m}$ Minisart filter (Sartorius AG, Goettingen, Germany) and stored in the dark at $-20^{\circ} \mathrm{C}$ until use. The cultures were incubated at $30^{\circ} \mathrm{C}$ for 24,48 and $72 \mathrm{~h}$ to determine optimal conditions for CLA production. Total viable counts (CFU) were determined by plating serial dilutions on MRS agar (Oxoid, Hampshire, $\mathrm{UK}$ ) and the $\mathrm{pH}$ value of the cultured media was determined using a $\mathrm{pH}$ meter (Mettler Toledo, Columbus, Ohio, USA) equipped with a combined electrode.

Based on the CLA production results obtained with the strains studied, four cocultures (Figure 1) were designed consisting of Lactococcus lactis (60\%, v/v) and Lactobacillus $(40 \%, \mathrm{v} / \mathrm{v})$ strains, having previously verified compatibility between strains by means of the agar spot test (Schillinger \& Lücke, 1989). The activated co-cultures were transferred at $5 \%(\mathrm{v} / \mathrm{v})$ to the MRS broth or the skim milk containing $0.5 \mathrm{mg} / \mathrm{mL}$ of LA and incubated at $30^{\circ} \mathrm{C}$ for 24,48 and $72 \mathrm{~h}$. All experiments were carried out in duplicate.

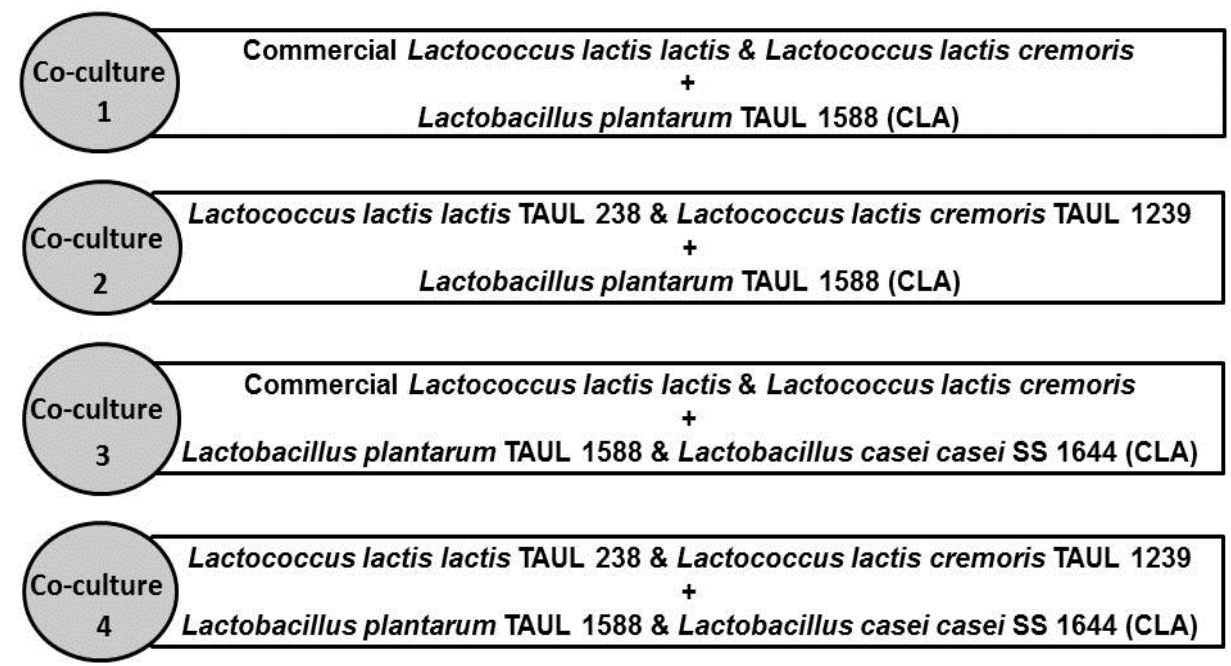

Figure 1. Description of each co-culture designed with Lactococcus lactis (commercial or autochthonous) strains and CLA-producing Lactobacillus strains. 


\section{Quantification of CLA production by gas chromatographic analysis}

Lipids were extracted from samples using the method described by Coakley et al. (2003) and fatty acids methyl esters (FAMES) were prepared by acid-catalysed methanolysis of glycerides (12\% methanolic $\mathrm{HCl}$ ) (Supelco, Bellefonte, PA, USA) following the above-mentioned method. Heptadecanoic acid (C 17:0) was used as internal standard. FAMES were analysed by gas chromatography (GC) and the chromatographic system consisted of an Agilent 7890 B Chromatography System (Agilent Technologies, Santa Clara, CA, USA) equipped with an Agilent 80 Series Injector (Agilent Technologies, Santa Clara, CA, USA) and fitted with a flame ionisation detector (FID).

FAMES separation was carried out using a Chrompak CP - Sil 88 capillary column (0.2 $\mu \mathrm{m}$ particle size, $100 \mathrm{~m} \times 0.25 \mathrm{~mm}$ I.D.) (Chrompack, Middelburg, Netherlands). Helium was used as a carrier gas at a flow rate of $1 \mathrm{~mL} / \mathrm{s}$. The injector temperature was held isothermally at $225^{\circ} \mathrm{C}$ for $10 \mathrm{~min}$ and the detector temperature was $250^{\circ} \mathrm{C}$. The column oven was held at an initial temperature of $140^{\circ} \mathrm{C}$ for $8 \mathrm{~min}$ and then programmed to increase at a rate of $8.5^{\circ} \mathrm{C} / \mathrm{min}$ to a final temperature of $200^{\circ} \mathrm{C}$, which was held for 41 min. Samples $(1 \mu \mathrm{L})$ were injected by splitless injection.

In order to determine the time of elution of each of the methyl esters of the CLA isomers and linoleic acid, and thus be able to identify and quantify them from the chromatograms, we prepared a series of dilutions from individual standard solutions of the three CLA isomers of interest in this study (cis-9,trans-11 $\mathrm{C}_{18: 2}$; trans-10,cis-12 $\mathrm{C}_{18: 2}$; trans-9, trans-1 $1 \mathrm{C}_{18: 2}$ ) (Larodan Fine Chemicals AB, Malmö, Sweden) and from a standard solution of linoleic acid (Sigma-Aldrich Co., St. Louis, MO, USA). This enabled us to obtain calibration curves for each of the FAMES under study and to quantify those present in the culture medium and in skim milk for the different strains studied. The CLA concentration naturally present in the skim milk media used in this study was subtracted from the analysed samples. The individual fatty acid content in the samples was expressed as $\mu \mathrm{g} / \mathrm{mL}$ of broth or skim milk.

\section{Statistical analysis}

All experimental data obtained on CLA production by LAB and co-cultures at different incubation times were statistically analysed using SPSS v.21 (SPSS, Chicago, IL, USA). The variables studied were tested for the assumptions of normality and homoscedasticity. Subsequently, we performed a one-way analysis of variance (ANOVA) and then applied Tukey's HSD post hoc test at a 5\% significance level.

\section{RESULTS AND DISCUSSION}

\section{CLA production by strains}

In the present study, 4 strains of Lactobacillus plantarum (TAUL 1539, TAUL 1588, TAUL 1795 and TAUL 1522) and 2 strains of Lactobacillus casei subsp. casei (SS 1614 and SS 1644), previously identified as CLA producers, were assayed for their capacity to transform LA into CLA in MRS or skim milk medium supplemented with $0.5 \mathrm{mg} / \mathrm{mL}$ of LA. Different incubation times $(24,48$ and $72 \mathrm{~h}$ ) were simultaneously assayed by GC to investigate these effects on CLA formation. This conjugated fatty acid has attracted much attention as a novel type of biologically beneficial functional lipid (Ogawa et al., 2005). 
The results presented in this paper showed that the optimal incubation time for total CLA production by all strains in MRS and skim milk was $48 \mathrm{~h}$, as described by Rodríguez-Alcalá, Braga, Malcata, Gomes, and Fontecha (2011), although Alonso et al. (2003) found no significant differences in CLA production by Lactobacillus strains after 24 $\mathrm{h}$ of incubation. Nieuwenhove, Oliszewski, Gozález, and Chaia (2007) have reported a relationship between the growth phase of the bacteria and the concentration of total CLA detected in the culture medium. The highest concentration of total CLA at $48 \mathrm{~h}$ may be related to the increase of the viable cell count compared to $24 \mathrm{~h}$ (Figure 2). Total CLA levels in the growth medium decreased significantly $(P \leq 0.05)$ after $72 \mathrm{~h}$ incubation. This could be due to oxidation reactions and oxidation metabolism carried out by the corresponding strain, which would favour a reaction towards catabolism of this compound (Ogawa, Matsumura, Kishino, Omura, \& Shimizu, 2001; Rodríguez-Alcalá et al., 2011; Wang, Lv, Chu, Cui, \& Ren, 2007).

A

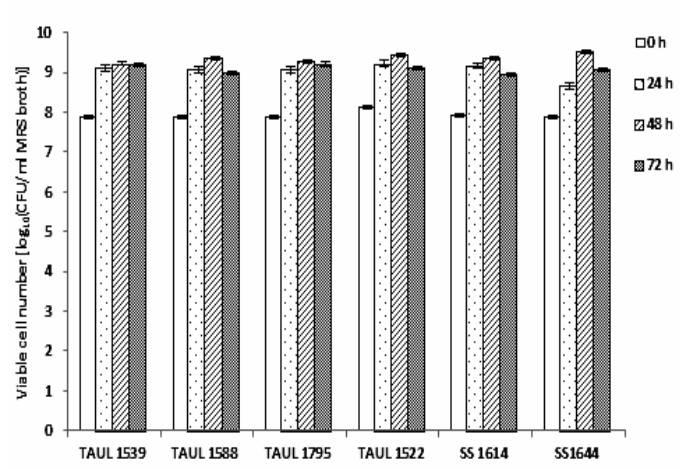

B

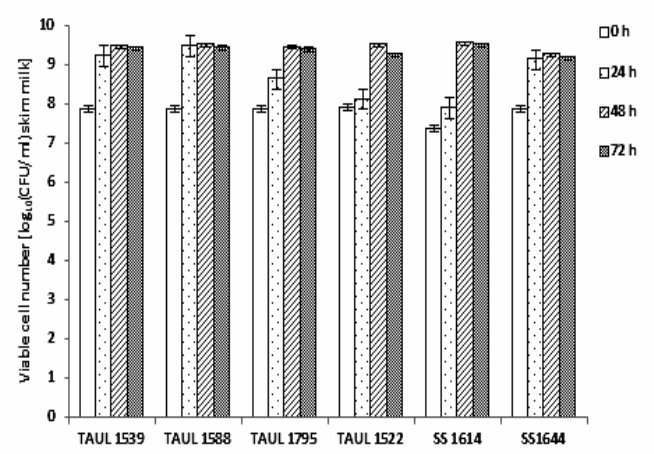

Figure 2. Viable cell count of each strain studied (A) in MRS broth and (B) in reconstituted skim milk (RSM) after 24,48 and $72 \mathrm{~h}$ of incubation at $30^{\circ} \mathrm{C}$.

The formation of total CLA was affected by the different media used. The capacity of Lactobacillus plantarum strains to produce total CLA was greatly reduced when they were grown in skim milk. However, in the case of Lactobacillus casei subsp. casei strains, CLA biosynthesis was more efficient in skim milk, reaching total CLA values at $48 \mathrm{~h}$ of incubation similar to those produced by Lactobacillus plantarum TAUL 1588 in MRS over the same time period. After $24 \mathrm{~h}$ incubation in skim milk, Lactobacillus plantarum TAUL 1588, TAUL 1795 and TAUL 1522 were unable to synthesise CLA, and Lactobacillus plantarum TAUL 1539 synthesised only $1.43 \mu \mathrm{g} / \mathrm{mL}$ of total CLA. However, Lactobacillus casei subsp. casei SS 1614 and SS 1644 produced 27.16 and $26.52 \mu \mathrm{g} / \mathrm{mL}$ of total CLA, respectively (data not shown). The reason for this is still unclear, but might be due to the fact that as Gorissen et al. (2011) have indicated, different environmental factors such as 
$\mathrm{pH}$ and temperature can affect the activity of linoleate isomerase, the enzyme involved in CLA synthesis from LA by LAB.

The GC analysis performed in the present study showed that under the experimental conditions, the six Lactobacillus strains produced three CLA isomers; cis9,trans-1 $1 \mathrm{C}_{18: 2}$, trans-10, cis-12 $\mathrm{C}_{18: 2}$ and trans-9,trans-1 $1 \mathrm{C}_{18: 2}$, except when grown in skim milk, when they only produced two CLA isomers; cis-9, trans- $11 \mathrm{C}_{18: 2}$ and trans-9, trans-11 $\mathrm{C}_{18: 2}$. Thus, the isomer trans-10,cis-12 $\mathrm{C}_{18: 2}$ was biosynthesized specifically in MRS. Nevertheless, even in MRS this was the least abundant isomer (around 10\% of total CLA in Lactobacillus plantarum, and around 20\% of total CLA in Lactobacillus casei supernatants) confirming the results obtained by Rodríguez-Alcala et al. (2011). Accordingly, the type of medium employed affected production of the different CLA isomers synthesised by the different strains. The importance of CLA isomers resides in the fact that several studies have reported that each isomer can have different effects on metabolism and cell functions, and each one acts through different cell signalling pathways. To date, cis-9, trans-11 $\mathrm{C}_{18: 2}$, trans-10,cis-12 $\mathrm{C}_{18: 2}$ and trans-9,trans-1 $1 \mathrm{C}_{18: 2}$ have attracted particular research attention due to their marked biological activities (Coakley et al., 2006; Ogawa et al., 2005).

The highest amount of cis-9, trans-1 $1 \mathrm{C}_{18: 2}$, trans-10, cis-12 $\mathrm{C}_{18: 2}$ and trans-9, trans- 11 $\mathrm{C}_{18: 2}$ in MRS broth supplemented with LA after $48 \mathrm{~h}$ was produced by Lactobacillus plantarum TAUL 1588, with values of $23.73,3.37$, and $27.97 \mu \mathrm{g} / \mathrm{mL}$, respectively, and $55.07 \mu \mathrm{g} / \mathrm{mL}$ total CLA (Table 1). Lactobacillus casei subsp. casei SS 1644 was the strain that produced the highest concentration of the CLA isomers cis-9,trans- $11 \mathrm{C}_{18: 2}$, and trans9, trans-1 $1 \mathrm{C}_{18: 2}$ in skim milk broth supplemented with LA after $48 \mathrm{~h}$, with values of 18.33 and $35.05 \mu \mathrm{g} / \mathrm{mL}$, respectively, and $53.38 \mu \mathrm{g} / \mathrm{mL}$ total CLA (Table 2). Although all 6 strains produced CLA from free LA as substrate, we found significant differences $(P \leq 0.05)$ in the concentration of the different CLA isomers synthesised by strains of the same species, suggesting that the capacity to produce this compound is dependent on strain and not on species.

Time of incubation affected the proportion of isomers synthesised by the Lactobacillus strains studied, all of which presented a common pattern. In MRS medium, after 24 and $48 \mathrm{~h}$ incubation, the main isomer detected was cis-9,trans-11 $\mathrm{C}_{18: 2}$, while after $72 \mathrm{~h}$ incubation it was trans-9, trans-11 $\mathrm{C}_{18: 2}$, in agreement with various authors (Ando, Ogawa, Kishino, \& Shimizu, 2004) which have reported that as incubation time increases, the concentration of the isomer trans-9,trans-1 $1 \mathrm{C}_{18: 2}$ tends to increase with respect to that of the isomer cis-9,trans-11 $\mathrm{C}_{18: 2}$. However, when the culture medium was skim milk, trans-9,trans-1 $1 \mathrm{C}_{18: 2}$ was the main isomer detected at all incubation times. Ogawa et al. (2005) have pointed out that the isomer cis-9,trans-11 $\mathrm{C}_{18: 2}$ can be interconverted towards the isomer trans-9,trans-11 $\mathrm{C}_{18: 2}$. At present, the mechanisms of production and interconversion among isomers are unclear and require further study. We speculate that some of these interconversion reactions specific for a particular isomer could require specific enzymatic activities that could be affected by the concentration of the other isomers or even the evolution of the $\mathrm{pH}$. 
Table 1.Production of individual isomers and total conjugated linoleic acid (CLA) by Lactobacillus plantarum and Lactobacillus casei subp. casei in MRS broth supplemented with $0.5 \mathrm{mg} / \mathrm{mL}$ of linoleic acid after $48 \mathrm{~h}$ of incubation at $30^{\circ} \mathrm{C}$.

\begin{tabular}{|c|c|c|c|c|c|c|}
\hline \multirow{2}{*}{ Culture } & \multirow{2}{*}{ pH } & \multirow{2}{*}{$\log _{10}$ CFU/mL } & \multicolumn{4}{|c|}{ Concentration $\mu \mathrm{g} / \mathbf{m L}^{1}$} \\
\hline & & & $c-9, t 11$ & $t-10, c-12$ & $t-9, t-11$ & Total CLA \\
\hline L. plantarum TAUL 1539 & 3.90 & $9.22(0.35)$ & $23.43(0.14)^{\mathrm{a}}$ & $3.20(0.09)^{\mathrm{a}}$ & $17.58(0.27)^{\mathrm{a}}$ & $44.20(0.32)^{\mathrm{a}}$ \\
\hline L. plantarum TAUL 1588 & 3.89 & $9.36(0.14)$ & $23.73(0.06)^{\mathrm{a}}$ & $3.37(0.12)^{\mathrm{a}}$ & $27.97(0.28)^{\mathrm{b}}$ & $55.07(0.21)^{\mathrm{b}}$ \\
\hline L. plantarum TAUL 1795 & 3.89 & $9.27(0.14)$ & $5.79(0.40)^{\mathrm{b}}$ & $3.08(0.16)^{\mathrm{a}}$ & $11.19(0.40)^{c}$ & $20.06(0.95)^{c}$ \\
\hline L. plantarum TAUL 1522 & 3.87 & $9.43(0.07)$ & $8.31(0.35)^{c}$ & $4.50(0.34)^{b}$ & $14.90(1.47)^{\mathrm{a}}$ & $27.71(2.17)^{\mathrm{d}}$ \\
\hline L. casei SS 1614 & 3.85 & $9.36(0.18)$ & $10.87(0.59)^{\mathrm{d}}$ & $5.06(0.21)^{\mathrm{bc}}$ & $10.70(0.75)^{\mathrm{c}}$ & $26.63(0.37)^{\mathrm{d}}$ \\
\hline L. casei SS 1644 & 3.98 & $9.52(0.14)$ & $13.43(0.37)^{\mathrm{e}}$ & $5.35(0.04)^{\mathrm{c}}$ & $11.33(0.11)^{\mathrm{c}}$ & $30.10(0.32)^{\mathrm{d}}$ \\
\hline
\end{tabular}

a-e Means in a column with different letter are significantly different $(P \leq 0.05)$

${ }^{1}$ Results as mean values of duplicate determination expressed as $\mu \mathrm{g} / \mathrm{mL}$ (standard deviations).

Table 2. Production of individual isomers and total conjugated linoleic acid (CLA) by Lactobacillus plantarum and Lactobacillus casei subp. casei in skim milk supplemented with $0.5 \mathrm{mg} / \mathrm{mL}$ of linoleic acid after $48 \mathrm{~h}$ of incubation at $30^{\circ} \mathrm{C}$.

\begin{tabular}{|c|c|c|c|c|c|}
\hline \multirow{2}{*}{ Culture } & \multirow{2}{*}{$\mathbf{p H}$} & \multirow{2}{*}{$\log _{10} \mathrm{CFU} / \mathrm{mL}$} & \multicolumn{3}{|c|}{ Concentration $\mu \mathrm{g} / \mathrm{mL}^{1}$} \\
\hline & & & $c-9, t 11$ & $t-9, t-11$ & Total CLA \\
\hline L. plantarum TAUL 1539 & 4.01 & $9.48(0.03)$ & $6.32(0.03)^{\mathrm{a}}$ & $4.57(0.16)^{\mathrm{a}}$ & $10.90(0.19)^{\mathrm{a}}$ \\
\hline L. plantarum TAUL 1588 & 3.96 & $9.47(0.11)$ & $8.51(0.49)^{\mathrm{a}}$ & $9.27(0.13)^{\mathrm{b}}$ & $17.78(0.62)^{\mathrm{b}}$ \\
\hline L. plantarum TAUL 1795 & 4.28 & $9.40(0.06)$ & $1.43(0.45)^{\mathrm{b}}$ & $5.28(0.25)^{\mathrm{a}}$ & $6.71(0.70)^{\mathrm{c}}$ \\
\hline L. plantarum TAUL 1522 & 4.05 & $9.60(0.35)$ & $0.88(0.25)^{\mathrm{b}}$ & $4.87(0.08)^{\mathrm{a}}$ & $5.74(0.33)^{\mathrm{c}}$ \\
\hline L. casei SS 1614 & 4.02 & $9.56(0.36)$ & $17.78(1.28)^{\mathrm{c}}$ & $33.91(0.675)^{\mathrm{c}}$ & $51.69(1.95)^{\mathrm{d}}$ \\
\hline L. casei SS 1644 & 4.01 & $9.17(0.09)$ & $18.33(0.63)^{\mathrm{c}}$ & $35.05(0.30)^{c}$ & $53.38(0.33)^{\mathrm{d}}$ \\
\hline
\end{tabular}

a-d Means in a column with different letter are significantly different $(P \leq 0.05)$

${ }^{1}$ Results as mean values of duplicate determination expressed as $\mu \mathrm{g} / \mathrm{mL}$ (standard deviations). 
Lactobacillus species are non-starter LAB which dominate cheese microbiota during ripening. They tolerate the hostile environment well and strongly influence the biochemistry of curd ripening, contributing to the development of the final characteristics of cheese (Settanni \& Moschetti, 2010). The amounts of CLA synthesised by the strains Lactobacillus plantarum TAUL 1588 and Lactobacillus casei subsp. casei SS 1644 at $48 \mathrm{~h}$ incubation in MRS culture medium and skim milk supplemented with $0.5 \mathrm{mg} / \mathrm{mL}$ of LA, respectively, were comparable with the results obtained in other studies of the same species (Alonso et al., 2003; Rodríguez-Alcalá et al., 2011; Terán et al., 2015). Consequently, the study of their potential use as a co-culture is of particular interest, since these findings suggest that they could be employed to manufacture functional fermented dairy products with elevated levels of CLA.

\section{CLA production by co-cultures}

Dairy products are the most important source of CLA in the human diet (Andrade et al., 2012). Based on the results reported above, we explored the possibility of designing cocultures that could increase CLA content in sheep milk cheese to reach the levels necessary to obtain the potential health-promoting effects of CLA on human health. Bathazar et al. (2017) indicate that the nutritional value of sheep milk is higher than those of goat and cow milks. Therefore, sheep milk is a good food matrix for the manufacture of functional cheese.

Since industrial starters generally include a strain of Lactococcus lactis as an acidifier, we therefore designed 4 co-cultures containing strains of this species combined with CLA-producing strains of Lactobacillus (Figure 1). Two of these contained Lactococcus lactis subsp. lactis and Lactococcus lactis subsp. cremoris, of commercial origin (CHOOZITтм LYO MA 011), while the other two contained Lactococcus lactis subsp. lactis TAUL 239 and Lactococcus lactis subsp. cremoris TAUL 1239, autochthonous isolates of Armada cheese (Herreros et al., 2003). None of the Lactococcus lactis strains included in this study were capable of producing CLA. These Lactococcus strains were selected for the design of the co-cultures because these strains showed good technological aptitude (Herreros et al., 2003) and in the compatibility test were the ones that presented better behavior with the CLA-producing strains and between them. The objective of this approach was to determine whether the co-culture with the commercial or autochthonous Lactococcus lactis strains affected CLA synthesis by CLA-producing strains. In the case of co-cultures 3 and 4 (Figure 1), our aim was to assess whether CLA production increased when using two CLA-producing strains in conjunction rather than individually. Therefore, we combined the Lactobacillus plantarum TAUL 1588 strain, which produced most CLA in MRS medium, with the Lactobacillus casei subsp. casei SS 1644 strain, which produced most CLA in skim milk.

The results obtained for total CLA content and each of the isomers produced by the four co-cultures designed, at different incubation times in MRS medium and in skim milk, are shown in figures $\mathbf{3}$ and $\mathbf{4}$, respectively. The incubation times presenting significant differences in CLA production between co-cultures are shown with different lowercase letters.

In MRS, the content of the isomer cis-9,trans-11 $\mathrm{C}_{18: 2}$ presented statistically significant differences $(P \leq 0.05)$ between co-cultures at 24,48 and $72 \mathrm{~h}$ incubation. In all 
cases, the highest concentration of this isomer was produced at $48 \mathrm{~h}$ and the co-cultures that showed greatest production of the isomer cis-9,trans-11 $\mathrm{C}_{18: 2}$ were co-cultures 1 and 2 , with no statistically significant differences $(P>0.05)$ between them. In the case of the isomer trans-10,cis-12 $\mathrm{C}_{18: 2}$, no statistically significant differences were observed $(P>0.05)$ between the different co-cultures throughout incubation. Content of the isomer trans9, trans-1 $1 \mathrm{C}_{18: 2}$ presented statistically significant differences $(P \leq 0.01)$ at $72 \mathrm{~h}$ incubation, and the highest concentration was produced by co-culture 2 . With respect to the total CLA produced by the co-cultures, as observed in the co-cultures with individual Lactobacillus strains, CLA production was greatest at $48 \mathrm{~h}$ incubation, after which the concentration of CLA began to decline significantly $(P \leq 0.05)$. The highest total CLA concentration at $48 \mathrm{~h}$ incubation was produced by co-culture 2, consisting of autochthonous strains of Lactococcus lactis subsp. lactis and the CLA-producing Lactobacillus plantarum TAUL 1588 strain, and co-culture 1, containing commercial strains of Lactococcus lactis subsp. lactis and Lactobacillus plantarum TAUL 1588. In MRS, these co-cultures produced almost double the concentration of CLA as that produced individually by the Lactobacillus plantarum TAUL 1588 strain in the same medium. Andrade et al. (2012) have indicated that environmental factors can affect CLA biosynthesis by LAB, explaining why the presence of Lactococcus species in this study enhanced conditions for CLA production by the Lactobacillus plantarum TAUL 1588 strain. As shown in Figure 3, the Lactococcus lactis strains (autochthonous or commercial) did not significantly affect $(P>0.05)$ CLA production by the co-culture, except at $72 \mathrm{~h}$ incubation. This was because in the case of co-culture 2, consisting of autochthonous strains of Lactococcus lactis, the reduction in CLA concentration was less marked than in the other co-cultures.
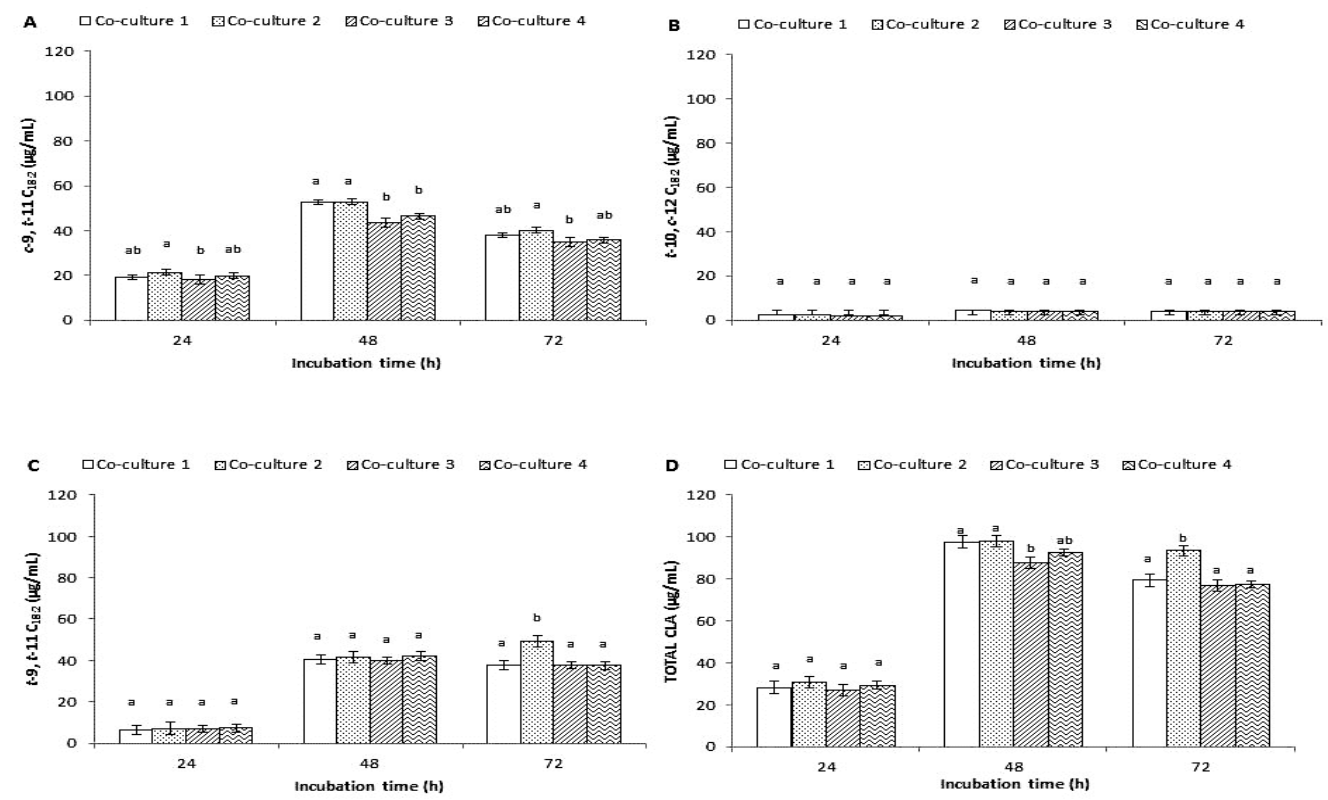

Figure 3. Co-cultures production of (A) cis-9,trans-11 CLA isomer; (B) trans-10, cis-12 CLA isomer; (C) trans-9,trans-11 CLA isomer; (D) total CLA in MRS broth after 24,48 and $72 \mathrm{~h}$ of incubation at $30^{\circ} \mathrm{C}$. Data represent mean $\pm \mathrm{SD}, \mathrm{n}=2$. Means for the same incubation time with different lowercase letters are significant at $P \leq 0.05$. 

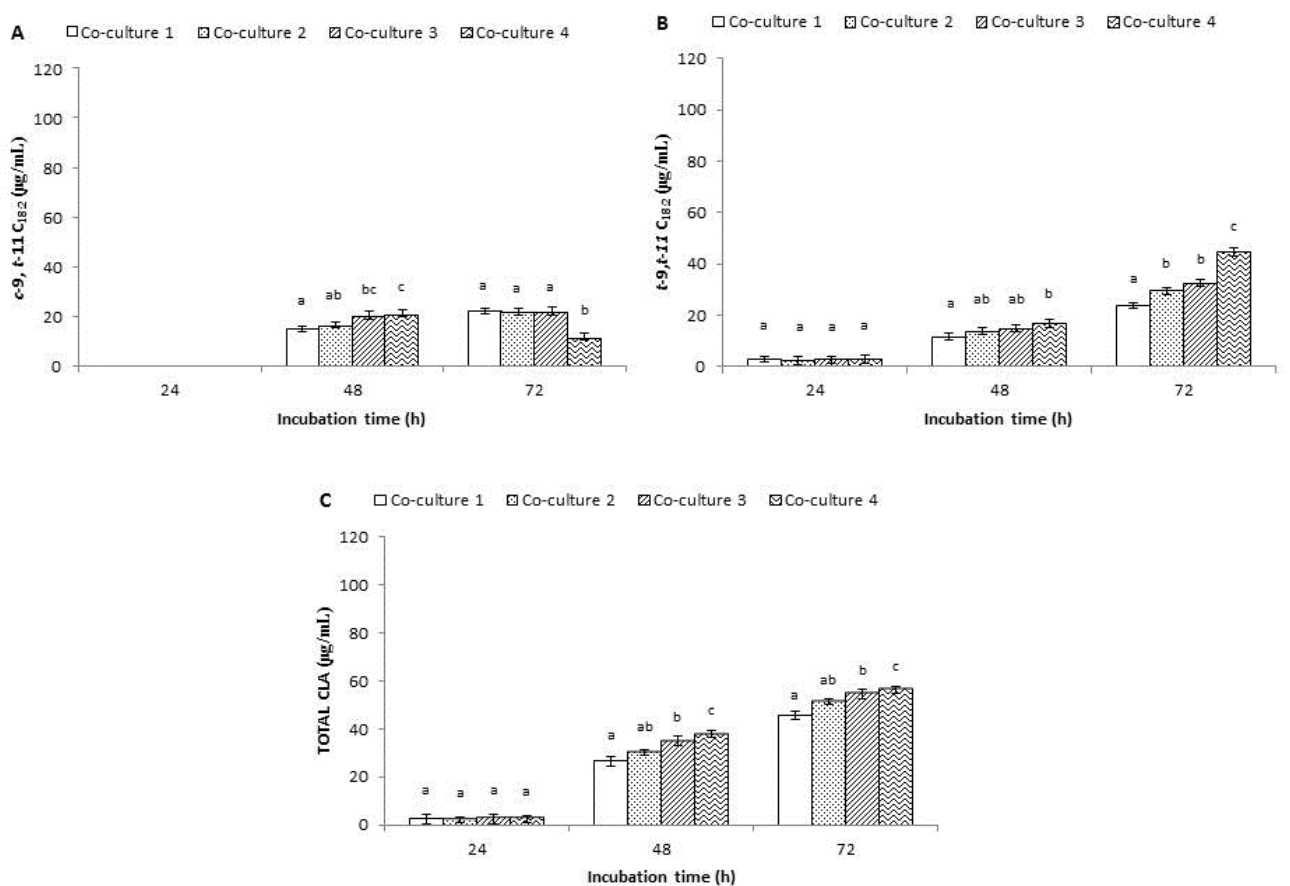

Figure 4. Starters production of (A) cis-9,trans-11 CLA isomer; (B) trans-9,trans-11 CLA isomer; (C) total CLA in reconstituted skim milk (RSM) after 24,48 and $72 \mathrm{~h}$ of incubation at $30^{\circ} \mathrm{C}$. Data represent mean \pm $\mathrm{SD}, \mathrm{n}=2$. Means for the same incubation time with different lowercase letters are significant at $P \leq 0.05$.

In MRS medium, the combination of CLA-producing strains from different species did not increase CLA concentrations at any incubation interval.

In skim milk, however, total CLA content and content of each of the isomers produced in skim milk by the four co-cultures at different incubation times (Figure 4) was different to that observed in MRS medium. Content of the isomer cis-9,trans-11 $\mathrm{C}_{18: 2}$ presented statistically significant differences $(P \leq 0.05)$ between co-cultures at 48 and $72 \mathrm{~h}$ incubation. For the latter incubation time, co-cultures 1,2 and 3 produced a higher concentration of this isomer, whereas with co-culture 4 it dropped by $9.40 \mu \mathrm{g} / \mathrm{mL}$ with respect to levels at $48 \mathrm{~h}$. The higher concentration of the isomer trans-9,trans- $11 \mathrm{C}_{18: 2}$ produced by co-culture 4 at $72 \mathrm{~h}$ incubation might be related both to its synthesis from LA and to a greater interconversion of the isomer cis-9,trans-11 $\mathrm{C}_{18: 2}$ towards this, in agreement with Ogawa et al. (2005). In turn, this would explain the reduction observed earlier in the concentration of the isomer cis-9,trans-11 $\mathrm{C}_{18: 2}$ produced by co-culture 4 .

As was the case when we studied CLA production by Lactobacillus strains in skim milk medium, none of the co-cultures was capable of synthesising the isomer trans-10,cis$12 \mathrm{C}_{18: 2 .}$

Highest total CLA production occurred at $72 \mathrm{~h}$ incubation. The highest CLA concentration was produced by co-culture 4 , which consisted of autochthonous strains of Lactococcus lactis and the CLA-producing strains Lactobacillus plantarum TAUL 1588 and 
Lactobacillus casei subsp. casei SS 1644. Co-cultures 1 and 2 synthesised the lowest concentrations of CLA, neither of which included the Lactobacillus casei subsp. casei strain; as observed in the study of strains, this species synthesised CLA more efficiently in skim milk than Lactobacillus plantarum. Accordingly, the presence of Lactobacillus casei subsp. casei SS 1644 in skim milk yielded a greater increase in CLA production in this medium than when using the Lactobacillus plantarum TAUL 1588 strain in isolation. The presence of autochthonous Lactococcus lactis strains significantly improved $(P<0.05)$ CLA production in skim milk medium in the case of co-culture 4 with respect to co-culture 3 and of co-culture 2 with respect to co-culture 1 .

\section{CONCLUSIONS}

In this study, we found that the strains Lactobacillus plantarum TAUL 1588 and Lactobacillus casei subsp. casei SS 1644 presented a good capacity to produce CLA, could be used as co-cultures together with Lactococcus lactis strains, and were more effective in combination with autochthonous strains of this species. The results reported here open the way for the use of co-cultures containing CLA-producing strains to manufacture cheese and thus obtain functional dairy products rich in bioactive fatty acids.

\section{ACKNOWLEDGMENTS}

The authors are grateful to the University of León (León, Spain) for granting a $\mathrm{PhD}$ fellowship to Erica Renes Bañuelos.

\section{REFERENCES}

Alonso, L., Cuesta, E. P., \& Gilliland, S. E. (2003). Production of free conjugated linoleic acid by Lactobacillus acidophilus and Lactobacillus casei of human intestinal origin. Journal of Dairy Science, 86(6), 1941-1946.

Ando, A., Ogawa, J., Kishino, S., \& Shimizu, S. (2004). CLA production from ricinoleic acid by lactic acid bacteria. Journal of the American Oil Chemists' Society, 80(9), 889-894.

Andrade, J. C., Ascençao, K., Gullón, P., Henriques, S. M. S., Pinto, J. M. S., RochaSantos, T. A. P., ... Gomes, A. M. (2012). Production of conjugated linoleic acid by food-grade bacteria: a review. International Journal of Dairy Technology, 65(4), 467481.

Balthazar, C. F., Pimentel, T. C., Ferrão, L. L., Almada, C. N., Santillo, A., Albenzio, M., ... Cruz, A. G. (2017). Sheep Milk: physicochemical characteristics and relevance for functional food development. Comprehensive Reviews in Food Science and Food Safety, 16(2), 247-262.

Barrett, E., Ross, R. P., Fitzgerald, G. F., \& Stanton, C. (2007). Rapid screening method for analyzing the conjugated linoleic acid production capabilities of bacterial cultures. Applied and Environmental Microbiology, 73(7), 2333-2337.

Coakley, M., Johnson, M. C., McGrath, E., Rahman, S., Ross, R. P., Fitzgerald, G. F., ... Stanton, C. (2006). Intestinal bifidobacteria that produce trans-9, trans-11 conjugated linoleic acid: a fatty acid with antiproliferative activity against human 
colon SW480 and HT-29 cancer cells. Nutrition and Cancer, 56(1), 95-102.

Coakley, M., Ross, R. P., Nordgren, M., Fitzgerald, G., Devery, R., \& Stanton, C. (2003). Conjugated linoleic acid biosynthesis by human-derived Bifidobacterium species. Journal of Applied Microbiology, 94(1), 138-145.

Ecker, J., Liebisch, G., Patsch, W., \& Schmitz, G. (2009). The conjugated linoleic acid isomer trans-9,trans-11 is a dietary occurring agonist of liver $\mathrm{X}$ receptor $\mathrm{a}$. Biochemical and Biophysical Research Communications, 388(4), 660-666.

González, L., Cuadrillero, A., Castro, J. M., Bernardo, A., \& Tornadijo, M. E. (2015). Selection of lactic acid bacteria isolated from San Simón da Costa Cheese (PDO) in order to develop an autochthonous starter culture. Advances in Microbiology, 5(5), 748-759.

Gorissen, L., Raes, K., Weckx, S., Dannenberger, D., Leroy, F., De Vuyst, L., \& De Smet, S. (2010). Production of conjugated linoleic acid and conjugated linolenic acid isomers by Bifidobacterium species. Applied Microbiology and Biotechnology, 87(6), 22572266.

Gorissen, L., Weckx, S., Vlaeminck, B., Raes, K., De Vuyst, L., De Smet, S., \& Leroy, F. (2011). Linoleate isomerase activity occurs in lactic acid bacteria strains and is affected by $\mathrm{pH}$ and temperature. Journal of Applied Microbiology, 111(3), 593-606.

Herreros, M. ., Fresno, J. M., González Prieto, M. J., \& Tornadijo, M. E. (2003). Technological characterization of lactic acid bacteria isolated from Armada cheese (a Spanish goats' milk cheese). International Dairy Journal, 13(6), 469-479.

Kim, B., Lim, H. R., Lee, H., Lee, H., Kang, W., \& Kim, E. (2016). The effects of conjugated linoleic acid (CLA) on metabolic syndrome patients: a systematic review and metaanalysis. Journal of Functional Foods, 25, 588-598.

Luna, P., Juárez, M., \& de la Fuente, M. A. (2007). Conjugated linoleic acid content and isomer distribution during ripening in three varieties of cheeses protected with designation of origin. Food Chemistry, 103(4), 1465-1472.

Nieuwenhove, V. C. P., Oliszewski, R., González, S. N., \& Pérez Chaia, A. B. (2007). Conjugated linoleic acid conversion by dairy bacteria cultured in MRS broth and buffalo milk. Letters in Applied Microbiology, 44(5), 467-474.

Ogawa, J., Kishino, S., Ando, A., Sugimoto, S., Mihara, K., \& Shimizu, S. (2005). Production of conjugated fatty acids by lactic acid bacteria. Journal of Bioscience and Bioengineering, 100(4), 355-364.

Ogawa, J., Matsumura, K., Kishino, S., Omura, Y., \& Shimizu, S. (2001). Conjugated linoleic acid accumulation via 10-hydroxy-12-octadecaenoic acid during microaerobic transformation of linoleic acid by Lactobacillus acidophilus. Applied and Environmental Microbiology, 67(3), 1246-1252.

Rodríguez-Alcalá, L. M., Braga, T., Malcata, X. F., Gomes, A., \& Fontecha, J. (2011). Quantitative and qualitative determination of CLA produced by Bifidobacterium and lactic acid bacteria by combining spectrophotometric and Ag+-HPLC techniques. Food Chemistry, 125(4), 1373-1378.

Rodríguez-Castañedas, J. L., Peña-Egido, M. J., García-Marino, M., \& García-Moreno, C. (2011). Quantitative determination of conjugated linoleic acid isomers by silver ion HPLC in ewe milk fat. Journal of Food Composition and Analysis, 24(7), 1004-1008.

Schillinger, U., \& Lücke, F. K. (1989). Antibacterial activity of Lactobacillus sake isolated 
from meat. Applied and Environmental Microbiology, 55(8), 1901-1906.

Settanni, L., \& Moschetti, G. (2010). Non-starter lactic acid bacteria used to improve cheese quality and provide health benefits. Food Microbiology, 27(6), 691-697.

Terán, V., Pizarro, P. L., Zacarías, M. F., Vinderola, G., Medina, R., \& Van Nieuwenhove, C. (2015). Production of conjugated dienoic and trienoic fatty acids by lactic acid bacteria and bifidobacteria. Journal of Functional Foods, 19(Part A), 417-425.

Wang, L. M., Lv, J. P., Chu, Z. Q., Cui, Y. Y., \& Ren, X. H. (2007). Production of conjugated linoleic acid by Propionibacterium freudenreichii. Food Chemistry, 103(2), 313-318.

Watkins, B. A., \& Li, Y. (2003). CLA in functional food: Enrichment of animal products. Advances in Conjugated Linoleic Acid Research, 2, 174-188.

Yang, B., Chen, H., Stanton, C., Ross, R. P., Zhang, H., Chen, Y. Q., \& Chen, W. (2015). Review of the roles of conjugated linoleic acid in health and disease. Journal of Functional Foods, 15, 314-325. 


\title{
CLA-producing adjunct cultures improve the nutritional value of sheep cheese fat
}

\author{
Erica Renes ${ }^{1}$, Pilar Gómez-Cortés², Miguel Ángel de la Fuente', Daniel M. Linares ${ }^{3}$, \\ María Eugenia Tornadijo ${ }^{1}$ and José María Fresno ${ }^{1}$ \\ ${ }^{1}$ Department of Food Hygiene and Technology, University of León, Spain. ${ }^{2}$ Institute of Food \\ Science Research (CIAL, CSIC-UAM), Madrid, Spain. ${ }^{3}$ Department of Food Biosciences, \\ Teagasc Food Research Centre, Moorepark, Ireland.
}

Food Research International, 2018 (Accepted; doi: 10.1016/j.foodres.2018.09.016)

\begin{abstract}
The influence of the autochthonous non-starter Lactobacillus plantarum TAUL 1588 and Lactobacillus casei subsp. casei SS 1644 strains, previously identified as conjugated linoleic acid (CLA) producers in vitro, and the ripening time on the fatty acid (FA) content and sensory characteristics of sheep cheese were investigated. Three batches with different cultures and the control batch were produced in duplicate and ripened for 8 months. 86 individual FA were determined by gas chromatography. Ripening time (2, 90, 180 and 240 days) did not have a significant effect $(P>0.05)$ on the FA content. However, the presence of both Lactobacillus CLA-producing strains led to a decrease of the total saturated FA content and to 1.30, 1.19 and 1.27 times higher levels of vaccenic acid, CLA and omega-3, respectively, when compared to the control batch. This combination resulted in sheep milk cheeses with a healthier FA content, without appreciable changes on sensory characteristics. This work could be a promising approach to increase the bioactive fatty acid content of cheeses.
\end{abstract}





\section{INTRODUCTION}

The development of foods with beneficial effects on human health is an aspect of great interest to the food industry and especially to the dairy industry (Balthazar et al., 2017). In relation to healthy food trends, milk and fermented dairy products contain lipid compounds that may exert beneficial effects on human health, such as conjugated linoleic acid (CLA) (Koba \& Yanagita, 2014; Lock, Kraft, Rice, \& Bauman, 2009; Tanaka, 2005). In contrast, dairy fat is a poor source in other bioactive lipids as omega-3 fatty acids (Parodi, 2004).

CLA is a group of positional and geometric isomers of octadecadienoic acid which are naturally found in foods derived from ruminants (Shingfield, Bonnet, \& Scollan, 2013). They are mainly biohydrogenation intermediates of dietary polyunsaturated fatty acids (PUFA). Rumenic acid or cis-9,trans-11 $\mathrm{C}_{18: 2}$, the major CLA isomer in dairy foods, is also synthesized in the ruminant mammary gland by the action of the $\Delta-9$ desaturase enzyme on vaccenic acid (trans-11 $\mathrm{C}_{18: 1}$ ) (Bichi et al., 2012), which is another intermediary in the ruminal biohydrogenation.

Balthazar et al. (2017) indicated that the nutritional value of sheep milk, mostly used for cheese manufacturing, could be higher than milk from other ruminants. In addition, various functional dairy products have been developed from sheep milk (Bárcenas et al., 2007). In the Mediterranean region, most sheep-milk production systems are semi-extensive, and grass plays an important role in the flocks' diet. As Gómez-Cortés et al. (2009) pointed out, the supply of grass and thus omega-3 PUFA in the livestock diet represents one of the strategies to enhance the content of these fatty acids and CLA in milk, and subsequently also in cheese (Shingfield et al., 2013).

Several studies have shown that strains of lactic acid bacteria (LAB) are able to synthesize CLA from linoleic acid in culture medium or milk (Gorissen et al., 2010; Ogawa et al., 2005; Renes et al., 2017a). This fact has opened new research lines aimed at increasing the CLA content of cheese by the use of starters or adjunct cultures able to biosynthesize CLA in vitro. The design of autochthonous CLA-producing cultures with application for the production of functional cheeses could increase the diversity of cultures available to the dairy industry but, research in this topic remains still very limited. Taboada, Van Niewenhove, Alzogaray, and Medina (2015) have shown that the CLA content of goat cheese could be increased by the use of autochthonous LAB strains and the same was observed by Mohan, Anand, Kalscheur, Hassan, and Hippen (2013) in Cheddar cheese. To the best of our knowledge, there is no information about the effect of the combination of different autochthonous CLA-producing strains used as a mixed adjunct culture on the fatty acid content of sheep milk cheese.

The objective of this study was to investigate the effect of two autochthonous Lactobacillus strains used as adjunct cultures, previously identified and characterized in vitro as CLA producers (Renes et al., 2017a, 2017b), to improve the nutritional value of sheep cheese fat without modifying the sensory properties of the cheeses. 


\section{MATERIAL AND METHODS}

\section{Preparation of cultures}

The autochthonous Lactococcus lactis subsp. lactis TAUL 238 and Lactococcus lactis subsp. cremoris TAUL 1239 strains were selected for their good technological aptitude showed in previous studies (Renes et al., 2017b) and both Lactococcus strains were the starter culture. The autochthonous Lactobacillus plantarum TAUL 1588 and Lactobacillus casei subsp. casei SS 1644 strains were selected for their good technological characteristics as well as for their ability to synthesize CLA in skim milk (Renes et al., 2017b). These Lactobacillus strains, individually or in combination, were used as adjunct cultures.

First, each LAB strain was cultured in MRS broth (Oxoid, Hampshire, UK) for Lactobacillus or Elliker broth (BD Difco, New Jersey, USA) for Lactococcus lactis at $30^{\circ} \mathrm{C}$ for $24 \mathrm{~h}$. Then, each strain was cultured in sterilised reconstituted skim milk $(10 \%, \mathrm{w} / \mathrm{v})$ at $30^{\circ} \mathrm{C}$ for $24 \mathrm{~h}$. Total viable counts (CFU/g) were determined by plating serial dilutions on MRS or Elliker agar (Oxoid, Hampshire, UK) and no significant differences $(P>0.05)$ were observed (data not shown). The strain composition of the designed cultures for cheese manufacture is shown in Table 1. Finally, each activated autochthonous cultures were transferred at $1 \%(\mathrm{v} / \mathrm{v})$ to sterilized sheep milk and incubated for $48 \mathrm{~h}$ at $30^{\circ} \mathrm{C}$.

\section{Milk and cheese manufacture}

Milk was obtained from a farm of Castellana breed sheep fed ad libitum with natural pasture.

Four sheep cheese batches were produced in duplicate at pilot scale (Institute of Food Science and Technology (ICTAL), University of León, Spain) according to the following method: milk was pasteurized at $72^{\circ} \mathrm{C}$ for $15 \mathrm{~s}$ and after cooling at $31^{\circ} \mathrm{C}$, calcium chloride $(0.2 \mathrm{~g} / \mathrm{L})$ and starter culture or starter culture plus adjunct $(1 \%, \mathrm{v} / \mathrm{v})$ were added. Batch 1 was the control and it was produced with the first autochthonous culture (non CLAproducing) indicated in Table 1. Batches 2, 3, and 4 were manufactured with the autochthonous cultures 2, 3, and 4 (CLA-producing), respectively (Table 1). After $30 \mathrm{~min}$, chymosin (CHY-MAX Extra, $100 \%$ chymosin; $600 \mathrm{IMCU} / \mathrm{mL}$; Chr. Hansen SL, Madrid, Spain) was added at a rate of $0.05 \mathrm{~mL} / \mathrm{L}$ of milk (diluted in 1:20 with deionized water).

After 40-45 $\mathrm{min}$, the curd was cut to rice grain size and the whey was drained off. The curd was transferred to cylindrical moulds $(15 \mathrm{~cm}$ height, $21 \mathrm{~cm}$ diameter) which were pressed for $2 \mathrm{~h}$.

Table 1. Strain composition $(\%, v / v)^{1}$ of autochthonous cultures.

\begin{tabular}{lcccc} 
Strains & \multicolumn{3}{c}{ Cultures } \\
\cline { 2 - 5 } & $\mathbf{1}$ & $\mathbf{2}$ & $\mathbf{3}$ & $\mathbf{4}$ \\
\hline Lc. lactis spp. lactis TAUL 238 (non CLA-producing) & 50 & 30 & 30 & 30 \\
Lc. lactis spp. cremoris TAUL 1239 (non CLA-producing) & 50 & 30 & 30 & 30 \\
Lb. plantarum TAUL 1588 (CLA-producing) & - & 40 & - & 20 \\
Lb. casei spp. casei SS1644 (CLA-producing) & - & - & 40 & 20 \\
\hline
\end{tabular}

${ }^{1}$ volume of each individual strain activated in milk respect to the final volume of the mixed culture in sheep milk. 
Then, cheeses were salted by immersion (18 ${ }^{\circ}$ Baume, $8^{\circ} \mathrm{C}$ and $\left.\mathrm{pH} 5.4\right)$ for $17 \mathrm{~h}$. Finally, the cheeses were taken to a ripening chamber where they remained at a temperature of $10^{\circ} \mathrm{C}$ and at $80-85 \%$ relative humidity for 240 days.

Samples (each sample corresponded to a whole cheese of $2.5 \mathrm{~kg}$ ) were taken from each case after 2, 90, 180 and 240 days of ripening. Part of the fresh samples was used to carry out the colour, texture and sensory analyses and another portion of the samples was vacuum packed and stored in a freezer $\left(-30^{\circ} \mathrm{C}\right)$ until fatty acid analysis.

\section{Determination of the fatty acids content in sheep cheese}

Cheese fat extraction was carried out using n-pentane after grind the sample with a mixture of sand and sodium sulfate (Bodas et al., 2010). Fatty acids were derivatized to methyl esters (FAME) by base-catalyzed methanolysis of glycerides with $\mathrm{KOH}$ in methanol (Bichi et al., 2012). FAME were analysed by gas chromatography with two different columns, CP-Sil 88 (100 $\mathrm{m} \times 0.25 \mathrm{~mm}$ i.d., Varian) and SLB-IL111 capillary column (100 $\mathrm{m} \times 0.25 \mathrm{~mm}$ i.d., Supelco). Detailed gas chromatography methods, identification of unknown FAME and quantification are described in a previous study (de la Fuente, Rodríguez-Pino, \& Juárez, 2015). Sheep milk cheeses were analysed for fatty acid composition after 2, 90, 180 and 240 days of ripening. The health indexes considered were: the omega-6/omega-3 ratio and the atherogenicity index (AI) defined as $\left[\left(\mathrm{C}_{12: 0}+4 \times \mathrm{C}_{14: 0}+\right.\right.$ $\left.\mathrm{C}_{16: 0}\right) /(\Sigma$ unsaturated FA)] (Ulbricht \& Southgate, 1991).

\section{Texture profile analysis}

Texture analysis was performed on eight cube-shaped $\left(1.9 \mathrm{~cm}^{3}\right)$ samples obtained from each cheese batch through the ripening time $(2,90,180,240$ days) at room temperature $\left(20^{\circ} \mathrm{C} \pm 2{ }^{\circ} \mathrm{C}\right)$. The cheese samples were kept at room temperature for approximately $3 \mathrm{~h}$ before analysis and a $0.5 \mathrm{~cm}$ layer from the surface of the cheese was removed. Texture properties of the batches were determined in two successive cycles of $80 \%$ compression with a cross-head constant speed of $0.5 \mathrm{~mm} / \mathrm{s}$ using a TZ-XT2 texture analyser (Stable Micro Systems, Godalming, UK). The following textural parameters were determined from the resultant force-time curve using the Texture Expert software (Stable Micro Systems, Godalming, UK): hardness (N), springiness, cohesiveness and chewiness (Pinho, Mendes, Alves, \& Ferreira, 2004).

\section{Colour instrumental measurement}

Colour analyses of sheep milk cheeses were performed throughout the ripening time $(2,90,180,240$ days) using a reflectance colorimeter spectrophotometer CM- $700 \mathrm{~d}$ (Konica Minolta, Osaka, Japan) provided with a measuring glass head of $8 \mathrm{~mm}$ of diameter, an illuminant D65 and a $10^{\circ}$ observer. The $\mathrm{L}^{*}, \mathrm{a}^{*}$, and $\mathrm{b}^{*}$ colour measurements were determined according to the CIELab colour space, were $L^{*}$ corresponds to light/dark chromaticity ( $0 \%$ dark to $100 \%$ light), $a^{*}$ to green/red chromaticity $(-60 \%$ green to $60 \%$ red), and b* to blue/yellow chromaticity ( $-60 \%$ blue to $60 \%$ yellow) (Pinho et al., 2004). The determination by triplicate of colour parameters was carried out measuring 12 different places on the longitudinal cheese sample surface $(1 \mathrm{~cm}$ thick). 


\section{Sensory analysis}

The sensory evaluation of the 4 cheese batches at 2 time points (180 and 240 days of ripening) was carried out by 20 panellists recruited from the Food Hygiene and Technology Department of the University of León, in gender proportion of 12 female and 8 male with ages between 22 and 60 years. Prior to the sensory evaluation of the cheese batches, the panel's members were trained in five training sessions of $1 \mathrm{~h}$ with commercial sheep milk cheeses. In this training, odour, flavour and texture attributes were defined and quantified according to the methodology previously described by Bárcenas et al. (2007) and Fresno and Álvarez (2012) for semi-hard and hard cheeses.

Cheese pieces of the same dimension $(4 \mathrm{~cm} \times 1.5 \mathrm{~cm} \times 0.5 \mathrm{~cm})$ of each batch were presented to the panel at ambient temperature $\left(20^{\circ} \mathrm{C} \pm 2{ }^{\circ} \mathrm{C}\right)$ and identified with a randomly 3 -digit code in one session for cheese batches at $180 \mathrm{~d}$ of ripening and another session for cheese batches at $240 \mathrm{~d}$ of ripening. Panel assessed a total of 15 sensory parameters, divided into 4 main groups: appearance (colour intensity ranging from white to yellow, holes size and homogenous distribution of the holes), odour (odour intensity, butyric, pungent and mouldy), taste (saltiness, bitterness, sweetness and acidity), and texture (elasticity, adhesiveness, firmness and solubility). These attributes were recorded on a 7 point intensity scale containing the following descriptors: (1) non-existent, (2) very weak, (3) weak, (4) moderate, (5) strong, (6) very strong and (7) extremely strong.

\section{Statistical analysis}

Statistical analysis of the experimental data was performed using SPSS v.21 (SPSS, Chicago, IL, USA). The variables studied were tested for the assumption of normality using the Shapiro-Wilk test and for homoscedasticity using the Levene test. Subsequently, a twoway Analysis of Variance (ANOVA) was performed in order to evaluate the effect of the factors culture and ripening time (as fixed factors) and the interaction between them. Tukey's HSD post hoc test was applied at a 5\% significance level in order to compare sheep cheeses manufactured with different autochthonous cultures throughout the ripening period.

The chromatographic data obtained were also analysed by multi-variant statistical techniques (Principal Component Analysis and Euclidean distance squared) by means of the statistical package Minitab 16 (Minitab Incorporated, 2010).

\section{RESULTS AND DISCUSSION}

\section{Cheese fatty acid content}

The study of the fatty acid composition of four sheep cheese batches produced with different autochthonous cultures was carried out throughout the ripening (at time points $2,90,180$ and 240 days). In all cheese batches, no statistically significant differences $(P>$ 0.05 ) were observed for the 86 fatty acids contents analysed during the different ripening time points. As the ripening time effect and the interaction between cultures and ripening time effects were no significant $(P>0.05)$, only means for the cultures effect are presented in tables 2 and 3. Similarly to this study, several authors have confirmed that ripening time does not affect the fatty acid content of cheeses (Bodas et al., 2010; dos Santos et al., 2012; Luna, Juárez, \& de la Fuente, 2007). 
On the contrary, the type of culture used in sheep cheese-making, had a significant effect $(P \leq 0.05)$ on the fatty acid composition. Saturated fatty acid (SFA) contents of the four batches are shown in Table 2. SFA were the predominant fatty acids in the cheeses accounting for $73 \%$ of total FAME in the control batch, $72 \%$ in batches 2 and 3 , and $70 \%$ in the batch 4 . Palmitic acid $\left(\mathrm{C}_{16: 0}\right)$ was found in major proportion, followed by myristic acid $\left(\mathrm{C}_{14: 0}\right)$. These results were similar to those described by Bodas et al. (2010) in their study of the fatty acid content of sheep cheeses produced with milk from flocks fed with different diets.

Table 2. Saturated, including odd and branched-chain, fatty acid composition (g/100 g of total fatty acids methyl esters) of the four sheep cheese batches produced with different cultures.

\begin{tabular}{|c|c|c|c|c|c|c|}
\hline \multirow{2}{*}{ Variable1 } & \multicolumn{4}{|c|}{ Batch2 } & \multirow{2}{*}{$\mathbf{S E}^{3}$} & \multirow{2}{*}{$P$-value } \\
\hline & 1 & 2 & 3 & $\overline{4}$ & & \\
\hline Total SFA & $73.08^{a}$ & $71.55^{b}$ & $71.55^{b}$ & $70.22^{c}$ & 0.19 & $* * *$ \\
\hline$\Sigma$ Non-BCFA & $71.27^{a}$ & $69.89^{b}$ & $69.89^{b}$ & $68.75^{c}$ & 0.18 & $* * *$ \\
\hline $4: 0$ & $4.20^{\mathrm{a}}$ & $4.30^{\mathrm{a}}$ & $4.34^{a}$ & $4.26^{a}$ & 0.03 & NS \\
\hline $5: 0$ & $0.03^{a}$ & $0.03^{a}$ & $0.03^{a}$ & $0.05^{b}$ & 0.00 & $* * *$ \\
\hline $6: 0$ & $3.24^{\mathrm{ab}}$ & $3.20^{\mathrm{a}}$ & $3.39^{\mathrm{bc}}$ & $3.54^{c}$ & 0.03 & $* * *$ \\
\hline $7: 0$ & $0.04^{a}$ & $0.03^{a}$ & $0.04^{a}$ & $0.06^{b}$ & 0.00 & $* * *$ \\
\hline $8: 0$ & $2.85^{\mathrm{a}}$ & $2.73^{a}$ & $3.00^{\mathrm{b}}$ & $3.33^{c}$ & 0.04 & $* * *$ \\
\hline 9:0 & $0.06^{a}$ & $0.05^{b}$ & $0.06^{a}$ & $0.10^{c}$ & 0.00 & $* * *$ \\
\hline 10:0 & $7.98^{a}$ & $7.33^{\mathrm{b}}$ & $7.97^{a}$ & $8.64^{c}$ & 0.09 & $* * *$ \\
\hline $11: 0$ & $0.06^{a}$ & $0.05^{b}$ & $0.06^{a}$ & $0.10^{c}$ & 0.00 & $* * *$ \\
\hline $12: 0$ & $4.39^{a}$ & $3.89^{b}$ & $4.12^{c}$ & $4.11^{c}$ & 0.04 & $* * *$ \\
\hline $13: 0$ & $0.08^{a}$ & $0.07^{b}$ & $0.08^{a}$ & $0.09^{c}$ & 0.00 & $* * *$ \\
\hline $14: 0$ & $10.71^{\mathrm{a}}$ & $10.15^{\mathrm{b}}$ & $9.83^{c}$ & $9.15^{\mathrm{d}}$ & 0.10 & $* * *$ \\
\hline $15: 0$ & $0.98^{a}$ & $0.82^{\mathrm{b}}$ & $0.85^{b}$ & $0.88^{c}$ & 0.01 & $* * *$ \\
\hline $16: 0$ & $26.08^{a}$ & $25.79^{a}$ & $24.57^{b}$ & $22.44^{c}$ & 0.27 & $* * *$ \\
\hline $17: 0$ & $0.63^{a}$ & $0.55^{b}$ & $0.55^{\mathrm{b}}$ & $0.49^{c}$ & 0.01 & $* * *$ \\
\hline $18: 0$ & $9.37^{\mathrm{a}}$ & $10.36^{b}$ & $10.46^{b}$ & $10.77^{\mathrm{c}}$ & 0.10 & $* * *$ \\
\hline $20: 0$ & $0.26^{a}$ & $0.29^{b}$ & $0.27^{\mathrm{a}}$ & $0.24^{c}$ & 0.01 & $* * *$ \\
\hline $21: 0$ & $0.05^{a}$ & $0.05^{a}$ & $0.05^{a}$ & $0.05^{a}$ & 0.00 & NS \\
\hline $22: 0$ & $0.11^{\mathrm{a}}$ & $0.10^{\mathrm{ab}}$ & $0.09^{b c}$ & $0.08^{c}$ & 0.00 & $* *$ \\
\hline $23: 0$ & $0.06^{a}$ & $0.05^{\mathrm{ab}}$ & $0.04^{b}$ & $0.03^{b}$ & 0.00 & $* *$ \\
\hline $24: 0$ & $0.06^{a}$ & $0.05^{\mathrm{ab}}$ & $0.05^{\mathrm{ab}}$ & $0.04^{b}$ & 0.00 & $* *$ \\
\hline$\Sigma$ BCFA & $1.82^{\mathrm{a}}$ & $1.67^{\mathrm{b}}$ & $1.66^{\mathrm{b}}$ & $1.58^{c}$ & 0.02 & $* * *$ \\
\hline $13: 0$ iso & $0.02^{a}$ & $0.02^{a}$ & $0.02^{a}$ & $0.02^{a}$ & 0.00 & NS \\
\hline $13: 0$ anteiso & $0.04^{a}$ & $0.04^{a}$ & $0.04^{a}$ & $0.03^{b}$ & 0.00 & $*$ \\
\hline $14: 0$ iso & $0.09^{a}$ & $0.07^{\mathrm{b}}$ & $0.07^{\mathrm{b}}$ & $0.06^{c}$ & 0.00 & $* * *$ \\
\hline $15: 0$ iso & $0.22^{\mathrm{a}}$ & $0.22^{\mathrm{a}}$ & $0.21^{\mathrm{b}}$ & $0.18^{c}$ & 0.00 & $* * *$ \\
\hline $15: 0$ anteiso & $0.42^{\mathrm{a}}$ & $0.37^{\mathrm{b}}$ & $0.39^{c}$ & $0.39^{c}$ & 0.00 & $* * *$ \\
\hline $16: 0$ iso & $0.21^{\mathrm{a}}$ & $0.21^{\mathrm{a}}$ & $0.20^{\mathrm{a}}$ & $0.17^{b}$ & 0.00 & $* * *$ \\
\hline $17: 0$ iso & $0.23^{a}$ & $0.24^{a}$ & $0.23^{a}$ & $0.23^{a}$ & 0.00 & NS \\
\hline $17: 0$ anteiso & $0.52^{a}$ & $0.44^{b}$ & $0.45^{b}$ & $0.44^{b}$ & 0.01 & $* * *$ \\
\hline $18: 0$ iso & $0.06^{a}$ & $0.06^{a}$ & $0.06^{\mathrm{a}}$ & $0.05^{b}$ & 0.00 & $* *$ \\
\hline
\end{tabular}

${ }^{1} \mathrm{BCFA}=$ branched-chain fatty acids; $\mathrm{SFA}=$ saturated fatty acids.

21: control cheese made with starter composed of Lactococcus lactis subsp. lactis TAUL 238 and Lc. lactis subsp. cremoris TAUL 1239 strains; 2: cheese made with starter 1 and Lactobacillus plantarum TAUL 1588; 3: cheese made with starter 1 and Lactobacillus casei subsp. casei SS 1644; 4: cheese made with starter 1 and both Lactobacillus strains used in batches 3 and 4.

${ }^{3} \mathrm{SE}=$ standard error. Results as mean values of duplicate determination of each fatty acid at 2, 90, 180 and 240 days of ripening.

a-dMeans in the same row with different superscripts are significantly different $(P \leq 0.05)$.

NS $P>0.05 ;{ }^{*} P \leq 0.05 ;{ }^{* *} P \leq 0.01 ;{ }^{* * *} P \leq 0.001$.

From a nutritional point of view, decreases of approximately 1.17 points on $\mathrm{C}_{12: 0}$, $\mathrm{C}_{14: 0}$ and $\mathrm{C}_{16: 0}$ contents in batch 4 were important and positive. This is because all these 
fatty acids are preferentially stored as body fat and are considered as hypercholesterolemic (Parodi, 2004).

Furthermore, one of the most important results of this study was that the combination of two strains of Lactobacillus in the culture used for cheese-making (batch 4) led to a significant $(P \leq 0.001)$ higher concentration of $\mathrm{C}_{6: 0}, \mathrm{C}_{8: 0}$ and $\mathrm{C}_{10: 0}(1.09,1.17$ and 1.08 more times, respectively), which have been associated with positive effects on human health (Nagao \& Yanagita, 2010; Parodi, 2004). These fatty acids are easily digestible, show a low tendency to be stored in the adipose tissue, are preferentially hydrolysed from the triglycerides molecules and are transferred directly from the intestine to the bloodstream. Afterwards, they are transported as free fatty acids to the liver where they are metabolized via mitochondrial $\beta$-oxidation without triglycerides resynthesize, acting as a quick energy source for cells. Furthermore, these short-chain fatty acids also play an interesting role on the sensory characteristics of cheeses due to their lower perception thresholds in comparison to longer-chain fatty acids (Laskaridis et al., 2013).

Cheese produced with the combination of both Lactobacillus strains showed the lowest concentration of $\mathrm{C}_{17: 0}$ and branched-chain fatty acids (BCFA) in comparison to cheeses produced with individual strains. This fact showed that the metabolism of the cultures used for cheese-making played an important role in the content of these minor FA in cheese, confirming the relationship between the production of odd and BCFA and the type of microorganism involved in the fermentative process.

The total amount of monounsaturated fatty acids (MUFA) was significantly different $(P \leq 0.05)$ increasing from $22.68 \%$ in the batch 1 , up to $24.64 \%$ of total fatty acids in batch 4 (Table 3). Batches 2 y 3 presented an intermediate proportion $(23.96 \%$ and $23.68 \%$, respectively) of MUFA between the other two batches.

Oleic acid ( $\mathrm{C}_{18: 1}$ cis-9) was the fatty acid of the MUFA group that was detected in the highest proportion for the four sheep cheese batches, ranging between $78-80 \%$ of the total MUFA analysed. Differently, Mohan et al. (2013) detected that Cheddar cheese produced with a CLA-producing strain had a lower content of oleic acid compared to the control cheese. In the present study, it was observed that the use of a combination of cultures including autochthonous CLA-producing strains generated increases of cis- $\mathrm{C}_{18: 1}$ isomers, mainly cis-9 (Table 3). This trend was also observed in the case of the trans-MUFA, being vaccenic acid the major isomer of trans- $\mathrm{C}_{18: 1}$ content in sheep cheese, which represented approximately $44 \%$ of total trans- $\mathrm{C}_{18: 1}$. Similarly, dos Santos et al. (2012) and Taboada et al. (2015) detected $1.49 \%-2.01 \%$ of vaccenic acid in goat cheese using CLA-producing strains. High vaccenic acid content in cheese would be desirable since it can be used by humans for the endogenous synthesis of rumenic acid (through the stearoyl Co-A enzyme) providing the beneficial effects on human health that have been attributed to this CLA isomer (Turpeinen et al., 2002).

The type of culture affected the PUFA content of sheep cheeses in this study (Table 3). Control batch presented $4.22 \%$ of total PUFA followed by batch 2 with $4.47 \%$. The PUFA proportion of the batches 3 and 4 was $4.75 \%$ and $4.99 \%$, respectively. Within this fatty acids group it is important to highlight the great importance of CLA and omega-3 fatty acids because they have been associated with beneficial effects on human health and the intake of these fatty acids through food is essential to achieve these beneficial effects (Swanson, Block, \& Mousa, 2012; Yang et al., 2015). Batch 4 produced using the 
combination of Lb. plantarum TAUL 1588 and Lb. casei subsp. casei SS 1644 in the culture contained 1.19 times higher content of total CLA than the control cheese and batches 2 and 3.

Table 3. Monounsaturated and polyunsaturated fatty acid composition $(\mathrm{g} / 100 \mathrm{~g}$ of total fatty acids methyl esters) and fatty acid indexes of the four sheep cheese batches produced with different cultures.

\begin{tabular}{|c|c|c|c|c|c|c|}
\hline \multirow{2}{*}{ Variable $^{1}$} & \multicolumn{4}{|c|}{ Batch2 } & \multirow{2}{*}{$\mathbf{S E}^{3}$} & \multirow{2}{*}{ P-value } \\
\hline & 1 & 2 & 3 & 4 & & \\
\hline Total MUFA & $22.68^{a}$ & $23.96^{b}$ & $23.68^{b}$ & $24.64^{c}$ & 0.116 & $* * *$ \\
\hline$\Sigma$ cis-MUFA & $19.79^{a}$ & $20.93^{b}$ & $20.63^{b}$ & $20.83^{b}$ & 0.105 & $* * *$ \\
\hline $10: 1$ & $0.26^{a}$ & $0.26^{a}$ & $0.26^{a}$ & $0.26^{a}$ & 0.003 & NS \\
\hline $12: 1 c-11$ & $0.06^{a}$ & $0.05^{b}$ & $0.05^{b}$ & $0.06^{a}$ & 0.001 & $* * *$ \\
\hline $14: 1 \quad c-9$ & $0.16^{\mathrm{a}}$ & $0.15^{\mathrm{ab}}$ & $0.14^{b}$ & $0.12^{\mathrm{c}}$ & 0.004 & $* * *$ \\
\hline$\sum$ cis- $16: 1$ & $0.96^{a}$ & $0.92^{b c}$ & $0.91^{c}$ & $0.94 a b$ & 0.007 & $* * *$ \\
\hline $16: 1 c-7$ & $0.21^{\mathrm{a}}$ & $0.21^{\mathrm{a}}$ & $0.23^{b}$ & $0.25^{c}$ & 0.004 & $* * *$ \\
\hline $16: 1 c-8$ & $0.02^{\mathrm{a}}$ & $0.02^{a}$ & $0.02^{a}$ & $0.03^{b}$ & 0.002 & $* *$ \\
\hline $16: 1 c-9$ & $0.62^{a}$ & $0.59^{b}$ & $0.56^{c}$ & $0.53^{d}$ & 0.005 & $* * *$ \\
\hline $16: 1 c-10$ & $0.07^{a}$ & $0.06^{\mathrm{ab}}$ & $0.06^{\mathrm{ab}}$ & $0.05^{b}$ & 0.003 & $*$ \\
\hline $16: 1 c-11$ & $0.03^{a}$ & $0.03^{a}$ & $0.03^{a}$ & $0.05^{b}$ & 0.003 & $* * *$ \\
\hline $16: 1 c-13$ & $0.02^{a}$ & $0.02^{a}$ & $0.02^{a}$ & $0.02^{a}$ & 0.002 & NS \\
\hline $17: 1 c-9$ & $0.21^{\mathrm{a}}$ & $0.18^{b}$ & $0.17^{b c}$ & $0.16^{c}$ & 0.005 & $* * *$ \\
\hline$\Sigma$ cis- $18: 1$ & $18.11^{\mathrm{a}}$ & $19.31^{b}$ & $19.05^{b}$ & $19.23^{b}$ & 0.102 & $* * *$ \\
\hline $18: 1 c-9$ & $17.00^{\mathrm{a}}$ & $18.14^{b}$ & $17.81^{\mathrm{b}}$ & $17.88^{b}$ & 0.100 & $* * *$ \\
\hline $18: 1 c-11$ & $0.65^{a}$ & $0.67^{a}$ & $0.69^{a}$ & $0.76^{\mathrm{b}}$ & 0.014 & $* * *$ \\
\hline $18: 1 c-12$ & $0.30^{a}$ & $0.33^{b}$ & $0.33^{b}$ & $0.32^{\mathrm{b}}$ & 0.003 & $* * *$ \\
\hline $18: 1 c-13$ & $0.03^{a}$ & $0.03^{a}$ & $0.04^{b}$ & $0.05^{c}$ & 0.002 & $* * *$ \\
\hline $18: 1 c-15$ & $0.07^{a}$ & $0.06^{a}$ & $0.10^{\mathrm{b}}$ & $0.12^{c}$ & 0.004 & $* * *$ \\
\hline $18: 1 c-16$ & $0.07^{a}$ & $0.08^{\mathrm{ab}}$ & $0.09^{b c}$ & $0.10^{c}$ & 0.003 & $* * *$ \\
\hline $20: 1 c-11$ & $0.04^{a}$ & $0.04^{a}$ & $0.04^{a}$ & $0.04^{a}$ & 0.002 & NS \\
\hline Other $20: 1$ & $0.00^{a}$ & $0.01^{b}$ & $0.01^{b}$ & $0.01^{b}$ & 0.001 & $* * *$ \\
\hline$\Sigma$ trans-MUFA & $2.89^{a}$ & $3.04^{b}$ & $3.05^{b}$ & $3.81^{\mathrm{c}}$ & 0.020 & $* * *$ \\
\hline $15: 1$ & $0.05^{a}$ & $0.04^{b}$ & $0.04^{b}$ & $0.04^{b}$ & 0.002 & $* *$ \\
\hline$\sum$ trans-16:1 & $0.22^{\mathrm{a}}$ & $0.21^{a}$ & $0.22^{\mathrm{a}}$ & $0.24^{b}$ & 0.005 & $* * *$ \\
\hline $16: 1 t-4$ & $0.01^{\mathrm{a}}$ & $0.01^{\mathrm{a}}$ & $0.01^{\mathrm{a}}$ & $0.01^{\mathrm{a}}$ & 0.001 & NS \\
\hline $16: 1 t-5$ & $0.01^{\mathrm{a}}$ & $0.01^{a}$ & $0.01^{\mathrm{a}}$ & $0.01^{\mathrm{a}}$ & 0.001 & NS \\
\hline $16: 1 t-6$ & $0.02^{\mathrm{a}}$ & $0.02^{a}$ & $0.02^{a}$ & $0.02^{\mathrm{a}}$ & 0.002 & NS \\
\hline $16: 1 t-7+t-8$ & $0.03^{a}$ & $0.03^{a}$ & $0.03^{a}$ & $0.03^{a}$ & 0.002 & NS \\
\hline $16: 1 t-9$ & $0.12^{\mathrm{a}}$ & $0.12^{\mathrm{a}}$ & $0.12^{\mathrm{a}}$ & $0.14^{b}$ & 0.002 & $* * *$ \\
\hline $16: 1 t-10$ & $0.02^{a}$ & $0.03^{a b}$ & $0.03^{a b}$ & $0.04^{b}$ & 0.002 & $* *$ \\
\hline$\Sigma$ trans-18:1 & $2.62^{\mathrm{a}}$ & $2.80^{\mathrm{b}}$ & $2.79^{\mathrm{b}}$ & $3.53^{c}$ & 0.019 & $* * *$ \\
\hline $18: 1 t-4$ & $0.02^{\mathrm{a}}$ & $0.02^{a}$ & $0.02^{a}$ & $0.02^{\mathrm{a}}$ & 0.001 & NS \\
\hline $18: 1 t-5$ & $0.02^{a}$ & $0.02^{a}$ & $0.02^{a}$ & $0.02^{a}$ & 0.002 & NS \\
\hline $18: 1 t-6+t-7+t-8$ & $0.21^{\mathrm{a}}$ & $0.22^{\mathrm{a}}$ & $0.22^{\mathrm{a}}$ & $0.24^{b}$ & 0.003 & $* * *$ \\
\hline $18: 1 t-9$ & $0.23^{a}$ & $0.26^{b}$ & $0.23^{a}$ & $0.26^{b}$ & 0.006 & $* *$ \\
\hline $18: 1 t-10$ & $0.29^{a}$ & $0.35^{b}$ & $0.36^{b}$ & $0.47^{c}$ & 0.009 & $* * *$ \\
\hline $18: 1 t-11(\mathrm{VA})$ & $1.19^{\mathrm{a}}$ & $1.17^{\mathrm{ab}}$ & $1.13^{\mathrm{b}}$ & $1.55^{c}$ & 0.013 & $* * *$ \\
\hline $18: 1 t-12$ & $0.41^{\mathrm{a}}$ & $0.46^{b}$ & $0.46^{b}$ & $0.54^{c}$ & 0.005 & $* * *$ \\
\hline $18: 1 t-16+c-14$ & $0.26^{a}$ & $0.31^{\mathrm{b}}$ & $0.36^{c}$ & $0.44^{\mathrm{d}}$ & 0.003 & $* * *$ \\
\hline
\end{tabular}

${ }^{1} \mathrm{AI}=$ atherogenicity index, calculated according to Ulbricht and Southgate (1991); CLA= conjugated linoleic acid; $\mathrm{MUFA}=$ monounsaturated fatty acids; $\mathrm{PUFA}=$ polyunsaturated fatty acids; $\mathrm{RA}=$ rumenic acid; VA= vaccenic acid.

21: control cheese made with starter composed of Lactococcus lactis subsp. lactis TAUL 238 and Lc. lactis subsp. cremoris TAUL 1239 strains; 2: cheese made with starter 1 and Lactobacillus plantarum TAUL 1588; 3: cheese made with starter 1 and Lactobacillus casei subsp. casei SS 1644; 4: cheese made with starter 1 and both Lactobacillus strains used in batches 3 and 4 .

${ }^{3} \mathrm{SE}=$ standard error. Results as mean values of duplicate determination of each fatty acid at 2, 90, 180 and 240 days of ripening.

a-dMeans in the same row with different superscripts are significantly different $(P \leq 0.05)$.

Ns $P>0.05 ;{ }^{*} P \leq 0.05 ;{ }^{* *} P \leq 0.01 ;{ }^{* * *} P \leq 0.001$. 
Table 3 (continuation). Monounsaturated and polyunsaturated fatty acid composition (g/100 g of total fatty acids methyl esters) and fatty acid indexes of the four sheep cheese batches produced with different cultures.

\begin{tabular}{|c|c|c|c|c|c|c|}
\hline \multirow{2}{*}{ Variable $^{1}$} & \multicolumn{4}{|c|}{ Batch2 $^{2}$} & \multirow{2}{*}{$\mathbf{S E}^{3}$} & \multirow{2}{*}{ P-value } \\
\hline & $\overline{1}$ & $\overline{2}$ & 3 & 4 & & \\
\hline Total PUFA & $4.22^{a}$ & $4.47^{b}$ & $4.75^{c}$ & $4.99^{d}$ & 0.036 & $* * *$ \\
\hline$\Sigma$ non-conjugated $18: 2$ & $2.78^{a}$ & $3.06^{\mathrm{b}}$ & $3.20^{\mathrm{c}}$ & $3.31^{\mathrm{d}}$ & 0.020 & $* * *$ \\
\hline $18: 2 c-9, t-13+t-8, c-12$ & $0.27^{\mathrm{a}}$ & $0.31^{b}$ & $0.35^{c}$ & $0.41^{\mathrm{d}}$ & 0.005 & $* * *$ \\
\hline $18: 2 c-9, t-12+t-8, c-13$ & $0.13^{a}$ & $0.15^{b}$ & $0.16^{b}$ & $0.18^{c}$ & 0.002 & $* * *$ \\
\hline $18: 2 t-9, c-12$ & $0.03^{a}$ & $0.03^{a}$ & $0.03^{a}$ & $0.02^{\mathrm{a}}$ & 0.002 & NS \\
\hline $18: 2 t-11, c-15$ & $0.05^{a}$ & $0.04^{a}$ & $0.11^{\mathrm{b}}$ & $0.18^{c}$ & 0.006 & $* * *$ \\
\hline $18: 2$ other $t, t$ & $0.17^{a}$ & $0.18^{a}$ & $0.18^{a}$ & $0.18^{a}$ & 0.004 & NS \\
\hline $18: 2 c-9, c-12$ & $2.11^{\mathrm{a}}$ & $2.34 \mathrm{bc}$ & $2.37 \mathrm{~b}$ & $2.32^{c}$ & 0.013 & $* * *$ \\
\hline $18: 2 c-9, c-15$ & $0.01^{\mathrm{a}}$ & $0.01^{\mathrm{a}}$ & $0.02^{b}$ & $0.02^{\mathrm{b}}$ & 0.001 & $* * *$ \\
\hline$\Sigma$ conjugated 18:2 (CLA) & $0.58^{a}$ & $0.56^{b}$ & $0.54^{c}$ & $0.69^{d}$ & 0.004 & $* * *$ \\
\hline $18: 2 t-7, c-9$ & $0.05^{a}$ & $0.07^{a}$ & $0.05^{a}$ & $0.06^{\mathrm{a}}$ & 0.005 & NS \\
\hline $18: 2 c-9, t-11(\mathrm{RA})$ & $0.48^{a}$ & $0.44^{b}$ & $0.44^{b}$ & $0.58^{c}$ & 0.006 & $* * *$ \\
\hline $18: 2 t-11, c-13$ & $0.01^{a}$ & $0.01^{\mathrm{a}}$ & $0.01^{\mathrm{a}}$ & $0.01^{\mathrm{a}}$ & 0.001 & NS \\
\hline $18: 2 t-11, t-13$ & $0.01^{a}$ & $0.01^{\mathrm{a}}$ & $0.01^{a}$ & $0.01^{\mathrm{a}}$ & 0.001 & NS \\
\hline $18: 2$ other $t, t$ & $0.03^{a}$ & $0.03^{a}$ & $0.03^{a}$ & $0.03^{a}$ & 0.002 & NS \\
\hline Total 18:2 & $3.36^{\mathrm{a}}$ & $3.62^{\mathrm{b}}$ & $3.74^{c}$ & $3.99^{d}$ & 0.021 & $* * *$ \\
\hline $18: 3 c-9, t-11, c-15$ & $0.05^{\mathrm{a}}$ & $0.06^{a}$ & $0.06^{\mathrm{a}}$ & $0.08^{b}$ & 0.004 & ** \\
\hline$\Sigma$ omega-6 & $2.40^{\mathrm{a}}$ & $2.63^{\mathrm{bc}}$ & $2.68^{\mathrm{b}}$ & $2.58^{\mathrm{c}}$ & 0.019 & $* * *$ \\
\hline $18: 3 n-6$ & $0.04^{a}$ & $0.04^{a}$ & $0.04^{a}$ & $0.04^{a}$ & 0.002 & NS \\
\hline $20: 2 n-6$ & $0.03^{a}$ & $0.02^{a}$ & $0.02^{a}$ & $0.02^{a}$ & 0.002 & NS \\
\hline $20: 3 n-6$ & $0.02^{a}$ & $0.02^{a}$ & $0.02^{a}$ & $0.02^{a}$ & 0.001 & NS \\
\hline $20: 4 n-6$ & $0.18^{a}$ & $0.17^{a}$ & $0.19^{a}$ & $0.14^{\mathrm{b}}$ & 0.014 & $* *$ \\
\hline $22: 4 n-6$ & $0.03^{a}$ & $0.03^{a}$ & $0.04^{a}$ & $0.03^{a}$ & 0.003 & NS \\
\hline$\Sigma$ omega-3 & $0.52^{a}$ & $0.50^{a}$ & $0.63^{b}$ & $0.66^{b}$ & 0.010 & $* * *$ \\
\hline $18: 3 n-3$ & $0.37^{a}$ & $0.36^{a}$ & $0.48^{b}$ & $0.49^{b}$ & 0.008 & $* * *$ \\
\hline $20: 5 n-3$ & $0.04^{a}$ & $0.03^{a}$ & $0.03^{a}$ & $0.04^{a}$ & 0.002 & NS \\
\hline $22: 5 n-3$ & $0.09^{a}$ & $0.09^{a}$ & $0.10^{a}$ & $0.12^{\mathrm{b}}$ & 0.005 & $* *$ \\
\hline $22: 6 n-3$ & $0.03^{a}$ & $0.02^{\mathrm{a}}$ & $0.03^{a}$ & $0.02^{\mathrm{a}}$ & 0.002 & NS \\
\hline omega-6/omega-3 & $4.63^{a}$ & $4.23^{b}$ & $4.24^{b}$ & $3.89^{c}$ & 0.074 & $* * *$ \\
\hline AI & $2.73^{a}$ & $2.47^{\mathrm{b}}$ & $2.39^{\mathrm{b}}$ & $2.14^{\mathrm{c}}$ & 0.040 & $* * *$ \\
\hline
\end{tabular}

${ }^{1} \mathrm{AI}=$ atherogenicity index, calculated according to Ulbricht and Southgate (1991); CLA= conjugated linoleic acid; MUFA= monounsaturated fatty acids; $\mathrm{PUFA}=$ polyunsaturated fatty acids; RA= rumenic acid; $\mathrm{VA}=$ vaccenic acid.

21: control cheese made with starter composed of Lactococcus lactis subsp. lactis TAUL 238 and Lc. lactis subsp. cremoris TAUL 1239 strains; 2: cheese made with starter 1 and Lactobacillus plantarum TAUL 1588; 3: cheese made with starter 1 and Lactobacillus casei subsp. casei SS 1644; 4: cheese made with starter 1 and both Lactobacillus strains used in batches 3 and 4 .

${ }^{3} \mathrm{SE}=$ standard error. Results as mean values of duplicate determination of each fatty acid at 2, 90, 180 and 240 days of ripening.

a-dMeans in the same row with different superscripts are significantly different $(P \leq 0.05)$.

${ }^{N S} P>0.05 ;{ }^{*} P \leq 0.05 ;{ }^{* *} P \leq 0.01 ;{ }^{* *} P \leq 0.001$

The combination of the two strains could generate more favourable conditions so that linoleate isomerase activity of both strains was optimal. This fact could explain the highest concentration of total CLA observed in batch 4 with respect to the control batch and batches 2 and 3. Gorissen et al. (2011) indicated that linoleate isomerase activity in LAB depends on environmental conditions such as $\mathrm{pH}$ or temperature and it is also strain dependent. Unfortunately, the mechanisms and factors that affect CLA synthesis by LAB remain unknown and it is necessary to carry out further studies. 
The chromatographic method used allowed to detect different CLA isomers. Rumenic acid was the major isomer detected in all cheese batches representing more than $80 \%$ of total CLA (Table 3). This fact was in accordance with that described by other authors in sheep cheese (Mele et al., 2011; Zlatanos, Laskaridis, Feist, \& Sagredos, 2002). These values were in agreement with those compiled by El-Salam and El-Shibiny (2014), highlighting the great interest of the combination of CLA-producing strains for cheesemaking, since it generated higher concentration of this bioactive fatty acid.

a-linolenic acid was the major omega-3 fatty acid in all sheep cheeses (Table 3). Batches including the Lb. casei subsp. casei SS 1644 strain showed higher concentration of this fatty acid. On the contrary, batch 2 containing the Lb. plantarum TAUL 1588 strain showed a similar a-linolenic acid content as the control batch. Consequently, Lb. casei strain could be responsible for the higher a-linolenic acid contents in sheep cheeses.

Overall, changes in the fatty acid content of the cheeses gave rise to significant differences $(P \leq 0.001)$ in the indexes related to human health (Table 3). High omega6/omega-3 ratio and atherogenicity index (AI) in foods do not imply that the consumption of these foods should be eliminated, but must be kept to a moderate level (Taboada et al., 2015). The omega-6/omega-3 values obtained for control batch (4.63) were significantly higher $(P \leq 0.001)$ than those observed in batches 2,3 and $4(4.23,4.24$ and 3.89, respectively). The same trend was observed for the AI values, where the control batch showed the highest value (2.73) for this index. Batches 2 and 3 presented lower $(P \leq 0.001)$ AI values (2.47 and 2.39) than the control batch. Finally, the batch that showed the lowest AI values (2.14) was the batch 4 .

As Astrup et al. (2016) described, current dietary recommendations indicate there is strong evidence that replacing SFA with MUFA and PUFA, reduces plasma LDL-cholesterol and cardiovascular disease risk. These authors also highlighted that according to the report of the Dietary Guidelines Advisory Committee (2015), strong and consistent evidence indicates that replacing SFA with PUFA reduces the risk of cardiovascular disease events and coronary mortality. However, this occurred when SFA is replaced by an adequate omega-6/omega-3 ratio (approximately 5:1), because replacement with only omega- 6 fatty acids may increase the risk of cardiovascular disease, cancer, and inflammatory and autoimmune diseases, whereas increased levels of omega-3 (a low omega-6/omega-3 ratio) exert suppressive effects (Simopoulos, 2002). Therefore, the results of the present study showed that the use of the autochthonous CLA-producing Lactobacillus plantarum TAUL 1588 and Lb. casei subsp. casei SS1644 strains as adjuncts for cheese-making enhanced the content of the fatty acids with beneficial properties on human health. This effect was higher when both strains were included in the culture (batch 4) compared to the culture that did not include CLA-producing strains (control batch).

Additionally, a principal component analysis (PCA) was performed in order to get a better picture of the fatty acid content showed by the four sheep batches throughout ripening (Figure 1). In the PCA plot, 3 main groups were identified along the first two components, which explained $91 \%$ of the total variation. Cheeses produced with the combination of the two strains were located on the right side of the plot and correlated with cis-, trans-, and total MUFA, non-conjugated and total $\mathrm{C}_{18: 2}$, total CLA, PUFA, omega6 , and omega-3. On the contrary, control cheeses were located on the left side of the plot 
and associated with the content of total SFA, omega-6/omega-3 ratio and AI. Cheeses that were part of batches 2 and 3 constituted a single group that presented intermediate values between batches 1 and 4 . Therefore, these results confirm that there is almost no variation related to the cheese-making process itself, and that the type of culture used in cheesemaking is the predominant factor influencing cheese fatty acid content (Tables 2 and 3). These results also confirmed that the autochthonous cultures previously detected as CLAproducers in vitro presented this ability when cheeses were produced (Renes et al., 2017b). Therefore, the results of the present study are of great interest in obtaining dairy products with improved fatty acid content from sheep milk.
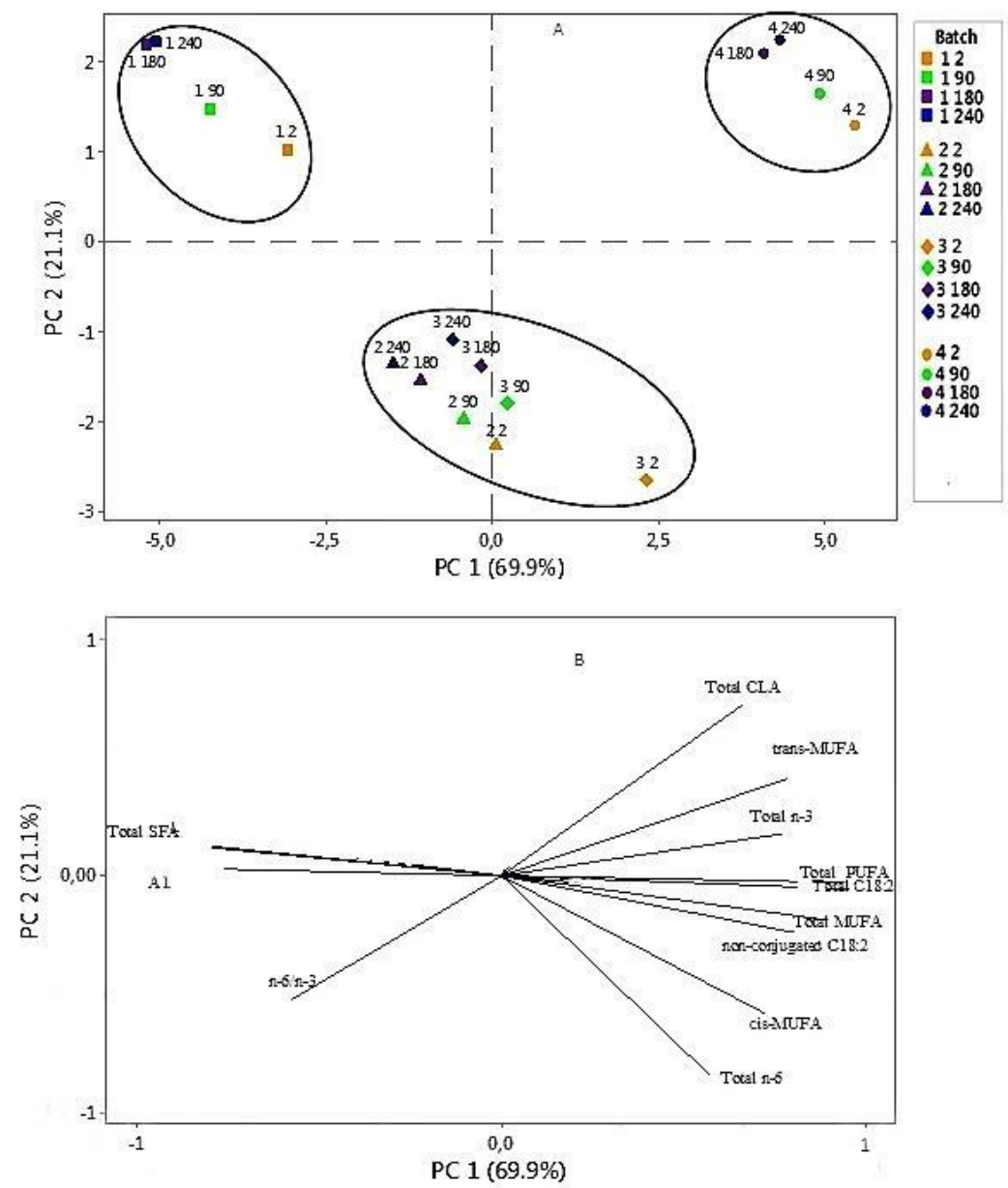

Figure 1. Score plot (A) and loading vectors (B) of the variables after principal component analysis of the fatty acid composition of the four different batches of sheep cheese throughout ripening $(2,90,180$ and 240 days). CLA $=$ conjugated linoleic acid; MUFA = monounsaturated fatty acids; PUFA= polyunsaturated fatty acids; $B C F A=$ branched-chain fatty acids; SFA= saturated fatty acids. 


\section{Texture, colour and sensory analysis}

In general, texture, colour and sensory data revealed that the use of different adjunct cultures for cheese-making did not lead to important changes on the analysed parameters.

The mean values obtained for the parameters of the texture profile analysis (TPA) and the colour analysis of the four cheese cases during ripening are presented in Table 4. Hardness increased up to 240 days of ripening in all the studied batches. At this ripening time, batches 1 and 2 showed the highest $(P \leq 0.01)$ hardness values. In general, cohesiveness and chewiness decreased slightly during the first 90 days of ripening, after which remained constant or increased slightly. However, springiness decreased gradually during all the ripening period, reaching after 240 days a final value $50 \%$ lower than the initial at 2 days. At 240 days of ripening, no significant differences $(P>0.05)$ were observed for cohesiveness, springiness and chewiness between the four cheese batches studied. In fact, important changes in texture occur during the first days of cheese ripening because initially the rubbery texture of young cheese is converted to a more homogeneous product and then a gradual change in texture occurs due to hydrolysis of caseins (Pinho et al., 2004).

No significant differences $(P>0.05)$ were observed for the colour parameters studied between the batches throughout 240 days of ripening. In all the cheese batches, a decrease in lightness $\left(\mathrm{L}^{*}\right)$ and an increase in redness $\left(\mathrm{a}^{*}\right)$ and yellowness $\left(\mathrm{b}^{*}\right)$ during cheese ripening was detected.

The mean scores allocated by the panellists for the attributes evaluated in the four cheese batches after 180 and 240 days of ripening are shown in Figure 2. The use of the selected strains as cultures did not cause any changes $(P>0.05)$ on the majority of the attributes studied in cheeses after 180 days of ripening. The control batch showed higher values of colour and odour intensity (Figure 2A). Regarding the colour attribute, no correlation was found with the results obtained in the instrumental analysis. For this ripening period $L^{*}, a^{*}$ and $b^{*}$ values were similar in the four cheese batches studied. None of the batches showed anomalous odour. At 240 days of ripening, significant differences were detected $(P \leq 0.05)$ for the attributes of odour and flavour intensity (Figure 2 B). Batches 2 and 3 presented the lowest score for odour and taste intensity. No significant correlation was observed between the values obtained for the texture attributes and those resulting from the TPA for neither of the two ripening times. This was observed due to the fact that panellists reported no noteworthy effect of the culture used for cheese-making on the texture attributes of the cheeses. In any case, even for significantly different attributes, the differences were small, always lower than 1 point in the perception scale.

\section{CONCLUSION}

The combination of the autochthonous Lactobacillus plantarum TAUL 1588 and Lactobacillus casei subsp. casei SS 1644 strains in the culture 4 led to healthier fatty acid content in the sheep cheese batch produced with it in comparison to the control batch. The sheep cheese batch produced with the culture including both Lactobacillus strains as adjunct cultures showed higher vaccenic acid, CLA and omega-3 levels, as well as lower $\mathrm{C}_{14: 0}$ and $\mathrm{C}_{16: 0}$ content, omega-6/omega-3 ratio and $\mathrm{AI}$ than the control batch. 
Table 4. Texture profile analysis and colour measurement of the four cheese batches during 240 days of ripening time.

\begin{tabular}{|c|c|c|c|c|c|c|c|c|}
\hline $\begin{array}{l}\text { Ripening } \\
\text { time }\end{array}$ & Batch 1 & Hardness (N) & Cohesiveness & Springiness & Chewiness & $\mathbf{L}^{*}$ & $a^{*}$ & $\mathbf{b}^{*}$ \\
\hline \multirow[t]{4}{*}{2 days } & 1 & $101.48 \pm 4.76^{\mathrm{aA}}$ & $0.19 \pm 0.02^{\mathrm{aA}}$ & $0.69 \pm 0.03^{\mathrm{aA}}$ & $12.21 \pm 1.02^{\mathrm{aA}}$ & $88.53 \pm 1.67^{\mathrm{aA}}$ & $-1.95 \pm 0.10^{\mathrm{aA}}$ & $14.58 \pm 0.51^{\mathrm{aA}}$ \\
\hline & 2 & $103.34 \pm 6.31^{\mathrm{aA}}$ & $0.18 \pm 0.01^{\mathrm{aA}}$ & $0.69 \pm 0.04 \mathrm{aA}$ & $11.59 \pm 0.46^{\mathrm{aA}}$ & $88.92 \pm 1.00^{\mathrm{aA}}$ & $-1.97 \pm 0.12^{\mathrm{aA}}$ & $14.05 \pm 0.46^{\mathrm{aA}}$ \\
\hline & 3 & $166.85 \pm 3.18^{\mathrm{bA}}$ & $0.21 \pm 0.01^{\mathrm{aA}}$ & $0.74 \pm 0.04 \mathrm{aA}$ & $25.86 \pm 2.63^{\mathrm{bA}}$ & $89.44 \pm 0.46^{\mathrm{aA}}$ & $-1.90 \pm 0.01 \mathrm{aA}$ & $14.64 \pm 0.46^{\mathrm{aA}}$ \\
\hline & 4 & $162.21 \pm 4.37 \mathrm{bA}$ & $0.18 \pm 0.02^{\mathrm{aA}}$ & $0.69 \pm 0.03^{\mathrm{aA}}$ & $19.55 \pm 2.76^{\mathrm{cA}}$ & $87.32 \pm 1.82^{\mathrm{aA}}$ & $-1.90 \pm 0.10^{\mathrm{aA}}$ & $14.33 \pm 0.52^{\mathrm{aA}}$ \\
\hline \multirow[t]{4}{*}{90 days } & 1 & $148.44 \pm 1.27 \mathrm{aB}$ & $0.13 \pm 0.01 \mathrm{aB}$ & $0.53 \pm 0.03 \mathrm{aB}$ & $7.65 \pm 5.11 \mathrm{aAB}$ & $75.94 \pm 1.27 \mathrm{aB}$ & $-2.69 \pm 0.13$ ав & $18.81 \pm 0.78 \mathrm{aB}$ \\
\hline & 2 & $133.45 \pm 8.88^{\mathrm{bB}}$ & $0.13 \pm 0.01 \mathrm{aB}$ & $0.36 \pm 0.04 \mathrm{bB}$ & $5.98 \pm 0.64 \mathrm{ac}$ & $75.75 \pm 2.054 \mathrm{aB}$ & $-3.03 \pm 0.11^{\mathrm{bB}}$ & $18.67 \pm 0.42^{\mathrm{aB}}$ \\
\hline & 3 & $180.84 \pm 7.35^{\mathrm{cB}}$ & $0.13 \pm 0.01 \mathrm{aB}$ & $0.49 \pm 0.05 \mathrm{aB}$ & $12.42 \pm 1.72^{\mathrm{aB}}$ & $77.74 \pm 1.84 \mathrm{aB}$ & $-2.25 \pm 0.18 \mathrm{cB}$ & $18.78 \pm 0.78^{\mathrm{aB}}$ \\
\hline & 4 & $174.98 \pm 7.43^{\mathrm{cB}}$ & $0.13 \pm 0.02^{\mathrm{aB}}$ & $0.42 \pm 0.04 \mathrm{abB}$ & $9.17 \pm 1.20^{\mathrm{aB}}$ & $76.53 \pm 1.47^{\mathrm{aB}}$ & $-2.49 \pm 0.22^{\mathrm{acB}}$ & $21.06 \pm 0.36^{\mathrm{bB}}$ \\
\hline \multirow[t]{4}{*}{180 days } & 1 & $293.42 \pm 7.95^{\mathrm{aC}}$ & $0.14 \pm 0.01^{\mathrm{aB}}$ & $0.38 \pm 0.02^{\mathrm{abc}}$ & $16.11 \pm 1.84^{\mathrm{aC}}$ & $75.75 \pm 2.45^{\mathrm{aB}}$ & $-1.93 \pm 0.26^{\mathrm{aA}}$ & $18.30 \pm 0.77 \mathrm{aB}$ \\
\hline & 2 & $230.37 \pm 2.12^{\mathrm{bc}}$ & $0.13 \pm 0.01 \mathrm{aB}$ & $0.30 \pm 0.03 \mathrm{aB}$ & $8.62 \pm 0.30 \mathrm{bCB}$ & $75.12 \pm 2.42^{\mathrm{aB}}$ & $-2.23 \pm 0.21 \mathrm{aA}$ & $19.36 \pm 0.88 \mathrm{aB}$ \\
\hline & 3 & $265.65 \pm 3.15^{\mathrm{abc}}$ & $0.13 \pm 0.01 \mathrm{aB}$ & $0.42 \pm 0.05^{\mathrm{bB}}$ & $13.64 \pm 2.11^{\mathrm{acB}}$ & $75.44 \pm 1.88^{\mathrm{aC}}$ & $-2.25 \pm 0.24 \mathrm{aB}$ & $18.59 \pm 0.76^{\mathrm{aB}}$ \\
\hline & 4 & $252.00 \pm 1.73^{\mathrm{abC}}$ & $0.13 \pm 0.01 \mathrm{aB}$ & $0.33 \pm 0.05^{\mathrm{ac}}$ & $10.82 \pm 1.35^{\mathrm{bcB}}$ & $74.64 \pm 0.86^{\mathrm{aB}}$ & $-2.29 \pm 0.19 \mathrm{aB}$ & $18.00 \pm 0.48^{\mathrm{aB}}$ \\
\hline \multirow[t]{4}{*}{240 days } & 1 & $324.00 \pm 1.52^{\mathrm{aD}}$ & $0.14 \pm 0.01^{\mathrm{aB}}$ & $0.31 \pm 0.03^{\mathrm{ac}}$ & $13.89 \pm 0.93^{\mathrm{aBC}}$ & $75.00 \pm 1.60^{\mathrm{aB}}$ & $-1.89 \pm 0.13^{\mathrm{aA}}$ & $19.43 \pm 0.56^{\mathrm{aB}}$ \\
\hline & 2 & $289.42 \pm 2.81^{\mathrm{abD}}$ & $0.13 \pm 0.01 \mathrm{aB}$ & $0.30 \pm 0.03^{\mathrm{aB}}$ & $11.22 \pm 2.10^{\mathrm{aAB}}$ & $74.99 \pm 1.80^{\mathrm{aB}}$ & $-2.22 \pm 0.20^{\mathrm{aA}}$ & $19.48 \pm 0.93^{\mathrm{aB}}$ \\
\hline & 3 & $267.31 \pm 2.09 \mathrm{bc}$ & $0.13 \pm 0.01 \mathrm{aB}$ & $0.35 \pm 0.03 \mathrm{ac}$ & $11.81 \pm 1.82^{\mathrm{aB}}$ & $74.84 \pm 0.86^{\mathrm{ac}}$ & $-2.29 \pm 0.19 \mathrm{aB}$ & $19.39 \pm 0.85^{\mathrm{aB}}$ \\
\hline & 4 & $266.03 \pm 2.71^{\mathrm{bD}}$ & $0.13 \pm 0.01^{\mathrm{aB}}$ & $0.32 \pm 0.04 \mathrm{aC}$ & $12.10 \pm 1.93^{\mathrm{aB}}$ & $74.61 \pm 2.48^{\mathrm{aB}}$ & $-2.22 \pm 0.27 \mathrm{aAB}$ & $19.87 \pm 0.54 \mathrm{aB}$ \\
\hline
\end{tabular}

11: control cheese made with starter composed of Lactococcus lactis subsp. lactis TAUL 238 and Lc. lactis subsp. cremoris TAUL 1239 strains; 2: cheese made with starter 1 and Lactobacillus plantarum TAUL 1588; 3: cheese made with starter 1 and Lactobacillus casei subsp. casei SS 1644; 4: cheese made with starter 1 and both Lactobacillus strains used in batches 3 and 4 .

a-dMeans \pm standard deviation in the same column with different superscripts (lowercase for differences between batches in the same time of ripening and uppercase for differences between ripening times in each batch) are significantly different $(P \leq 0.05)$. 
A

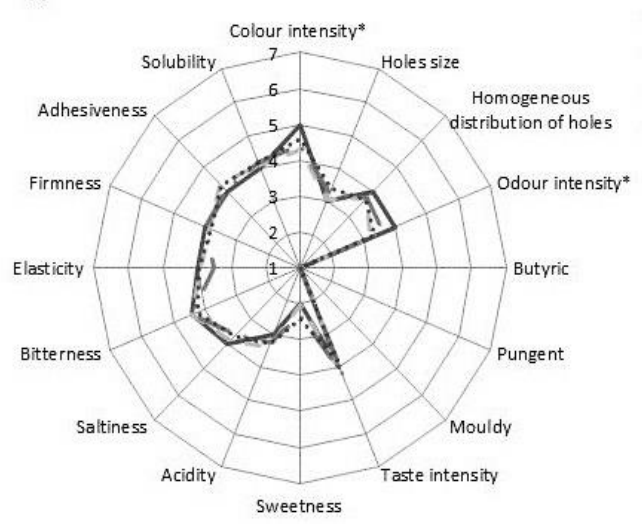

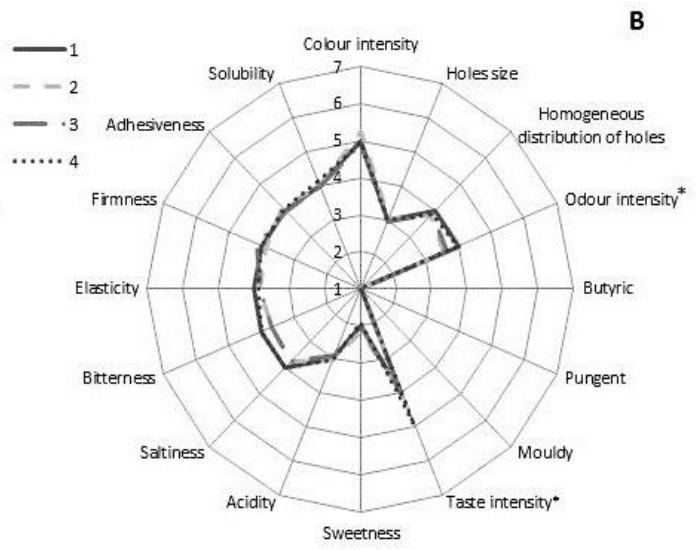

Figure 2. Sensory analysis of the four sheep cheese batches after 180 days (A) and 240 days (B) of ripening. 1: control cheese made with starter composed of Lactococcus lactis subsp. lactis TAUL 238 and Lc. lactis subsp. cremoris TAUL 1239 strains; 2: cheese made with starter 1 and Lactobacillus plantarum TAUL 1588; 3: cheese made with starter 1 and Lactobacillus casei subsp. casei SS 1644; 4: cheese made with starter 1 and both Lactobacillus strains used in batches 3 and 4 . *Denotes attributes significantly different $(P<0.05)$ between batches.

In addition, these fatty acid content changes in sheep cheeses did not generate differences on their sensory characteristics. Overall, the use of these autochthonous CLAproducing cultures could be a promising approach to improve the nutritional quality of cheese fat with special emphasis on bioactive fatty acids, which would be of special interest to the dairy industry in order to meet consumer demands.

\section{ACKNOWLEDGMENTS}

The authors are grateful to the University of León (León, Spain) for granting a $\mathrm{PhD}$ fellowship to Erica Renes Bañuelos. Pilar Gómez-Cortés was subsidized with a Juan de la Cierva research contract from the Ministerio de Economía y Competitividad. The authors also wish to acknowledge the Consortium for Ovine Promotion (Villalpando, Zamora, Castilla-León, Spain). The authors thank to F.J. Zorita for his technical assistance.

\section{REFERENCES}

Astrup, A., Rice Bradley, B., Brenna, J., Delplanque, B., Ferry, M., \& Torres-Gonzalez, M. (2016). Regular-fat dairy and human health: a synopsis of symposia presented in Europe and North America (2014-2015). Nutrients, 8(8), 463.

Balthazar, C. F., Pimentel, T. C., Ferrão, L. L., Almada, C. N., Santillo, A., Albenzio, M., Mollakhalili, N., Mortazavian, A.M., Nascimiento, J.S., Silva, M.C., Freitas, M.Q., Sant'Ana, A.S., Granato, D., \& Cruz, A. G. (2017). Sheep milk: physicochemical characteristics and relevance for functional food development. Comprehensive Reviews in Food Science and Food Safety, 16(2), 247-262. 
Bárcenas, P., Pérez Elortondo, F. J., Albisu, M., Mège, J., Bivar Roseiro, L., Francesca Scintu, M., Torre, P., Loygorri, S., \& Lavanchy, P. (2007). An international ring trial for the sensory evaluation of raw ewes' milk cheese texture. International Dairy Journal, 17(9), 1139-1147.

Bichi, E., Toral, P. G., Hervás, G., Frutos, P., Gómez-Cortés, P., Juárez, M., \& de la Fuente, M. A. (2012). Inhibition of $\Delta 9$-desaturase activity with sterculic acid: Effect on the endogenous synthesis of cis-9 18:1 and cis-9, trans-11 18:2 in dairy sheep. Journal of Dairy Science, 95(9), 5242-5252.

Bodas, R., Manso, T., Mantecón, A. R., Juárez, M., De la Fuente, M. A., \& Gómez-Cortés, P. (2010). Comparison of the fatty acid profiles in cheeses from ewes fed diets supplemented with different plant oils. Journal of Agricultural and Food Chemistry, 58(19), 10493-10502.

de la Fuente, M. A., Rodríguez-Pino, V., \& Juárez, M. (2015). Use of an extremely polar 100-m column in combination with a cyanoalkyl polysiloxane column to complement the study of milk fats with different fatty acid profiles. International Dairy Journal, $47,52-63$.

dos Santos, K. M. O., Bomfim, M. A. D., Vieira, A. D. S., Benevides, S. D., Saad, S. M. I., Buriti, F. C. A., \& Egito, A. S. (2012). Probiotic caprine Coalho cheese naturally enriched in conjugated linoleic acid as a vehicle for Lactobacillus acidophilus and beneficial fatty acids. International Dairy Journal, 24(2), 107-112.

El-Salam, M. H. A., \& El-Shibiny, S. (2014). Conjugated linoleic acid and vaccenic acid contents in cheeses: An overview from the literature. Journal of Food Composition and Analysis, 33(1), 117-126.

Fresno, M., \& Álvarez, S. (2012). Chemical, textural and sensorial changes during the ripening of Majorero goat cheese. International Journal of Dairy Technology, 65(3), 393-400.

Gómez-Cortés, P., Frutos, P., Mantecón, A. R., Juárez, M., de la Fuente, M. A., \& Hervás, G. (2009). Effect of supplementation of grazing dairy ewes with a cereal concentrate on animal performance and milk fatty acid profile. Journal of Dairy Science, 92(8), 3964-3972.

Gorissen, L., Raes, K., Weckx, S., Dannenberger, D., Leroy, F., De Vuyst, L., \& De Smet, S. (2010). Production of conjugated linoleic acid and conjugated linolenic acid isomers by Bifidobacterium species. Applied Microbiology and Biotechnology, 87(6), 22572266.

Gorissen, L., Weckx, S., Vlaeminck, B., Raes, K., De Vuyst, L., De Smet, S., \& Leroy, F. (2011). Linoleate isomerase activity occurs in lactic acid bacteria strains and is affected by $\mathrm{pH}$ and temperature. Journal of Applied Microbiology, 111(3), 593-606.

Koba, K., \& Yanagita, T. (2014). Health benefits of conjugated linoleic acid (CLA). Obesity Research \& Clinical Practice, 8(6), 525-532.

Laskaridis, K., Serafeimidou, A., Zlatanos, S., Gylou, E., Kontorepanidou, E., \& Sagredos, A. (2013). Changes in fatty acid profile of feta cheese including conjugated linoleic acid. Journal of the Science of Food and Agriculture, 93(9), 2130-2136.

Lock, A. L., Kraft, J., Rice, B. H., \& Bauman, D. E. (2009). Biosynthesis and biological activity of rumenic acid: a natural CLA isomer. In F. Destaillats, J. L. Sébédio, F. Dionisi, \& J. M. Chardigny (Eds.), Trans Fatty Acids In Human Nutrition (2nd ed., pp. 
195-230). Bridgwater: The Oily Press.

Luna, P., Juárez, M., \& de la Fuente, M. A. (2007). Conjugated linoleic acid content and isomer distribution during ripening in three varieties of cheeses protected with designation of origin. Food Chemistry, 103(4), 1465-1472.

Mele, M., Contarini, G., Cercaci, L., Serra, A., Buccioni, A., Povolo, M., ... Secchiari, P. (2011). Enrichment of Pecorino cheese with conjugated linoleic acid by feeding dairy ewes with extruded linseed: effect on fatty acid and triglycerides composition and on oxidative stability. International Dairy Journal, 21(5), 365-372.

Mohan, M. S., Anand, S., Kalscheur, K. F., Hassan, A. N., \& Hippen, A. R. (2013). Starter cultures and cattle feed manipulation enhance conjugated linoleic acid concentrations in Cheddar cheese. Journal of Dairy Science, 96(4), 2081-2094.

Nagao, K., \& Yanagita, T. (2010). Medium-chain fatty acids: Functional lipids for the prevention and treatment of the metabolic syndrome. Pharmacological Research, 61(3), 208-212.

Ogawa, J., Kishino, S., Ando, A., Sugimoto, S., Mihara, K., \& Shimizu, S. (2005). Production of conjugated fatty acids by lactic acid bacteria. Journal of Bioscience and Bioengineering, 100(4), 355-364.

Parodi, P. W. (2004). Milk fat in human nutrition. Australian Journal of Dairy Technology, 59(1), 3.

Pinho, O., Mendes, E., Alves, M. M., \& Ferreira, I. M. P. L. V. O. (2004). Chemical, physical, and sensorial characteristics of "Terrincho" ewe cheese: changes during ripening and intravarietal comparison. Journal of Dairy Science, 87(2), 249-257.

Renes, E., Linares, D. M., González, L., Fresno, J. M., Tornadijo, M. E., \& Stanton, C. (2017a). Production of conjugated linoleic acid and gamma-aminobutyric acid by autochthonous lactic acid bacteria and detection of the genes involved. Journal of Functional Foods, 34, 340-346.

Renes, E., Linares, D. M., González, L., Fresno, J. M., Tornadijo, M. E., \& Stanton, C. (2017b). Study of the conjugated linoleic acid synthesis by Lactobacillus strains and by different co-cultures designed for this ability. Journal of Functional Foods, 35, 7480.

Shingfield, K. J., Bonnet, M., \& Scollan, N. D. (2013). Recent developments in altering the fatty acid composition of ruminant-derived foods. Animal, 7(1), 132-162.

Simopoulos, A. P. (2002). The importance of the ratio of omega-6/omega-3 essential fatty acids. Biomedicine \& Pharmacotherapy, 56(8), 365-379.

Swanson, D., Block, R., \& Mousa, S. A. (2012). Omega-3 fatty acids EPA and DHA: health benefits throughout life. Advances in Nutrition: An International Review Journal, 3(1), $1-7$.

Taboada, N., Van Nieuwenhove, C., Alzogaray, S. L., \& Medina, R. (2015). Influence of autochthonous cultures on fatty acid composition, esterase activity and sensory profile of Argentinean goat cheeses. Journal of Food Composition and Analysis, 40, 86-94.

Tanaka, K. (2005). Occurrence of conjugated linoleic acid in ruminant products and its physiological functions. Animal Science Journal, 76(4), 291-303.

Turpeinen, A. M., Mutanen, M., Aro, A., Salminen, I., Basu, S., Palmquist, D. L., \& Griinari, J. M. (2002). Bioconversion of vaccenic acid to conjugated linoleic acid in 
humans. The American Journal of Clinical Nutrition, 76(3), 504-510.

Ulbricht, T. L. V, \& Southgate, D. A. T. (1991). Coronary heart disease: seven dietary factors. The Lancet, 338(8773), 985-992.

Yang, B., Chen, H., Stanton, C., Ross, R. P., Zhang, H., Chen, Y. Q., \& Chen, W. (2015). Review of the roles of conjugated linoleic acid in health and disease. Journal of Functional Foods, 15, 314-325.

Zlatanos, S., Laskaridis, K., Feist, C., \& Sagredos, A. (2002). CLA content and fatty acid composition of Greek Feta and hard cheeses. Food Chemistry, 78(4), 471-477. 


\title{
CAPÍTULO 5
}

\section{Production of sheep milk cheese with high $\gamma$-aminobutyric acid and ornithine concentration and with reduced biogenic amines level using autochthonous lactic acid bacteria strains}

\author{
Erica Renes ${ }^{1}$, Victor Ladero ${ }^{2}$, María Eugenia Tornadijo ${ }^{1}$ and José María Fresno ${ }^{1}$, \\ ${ }^{1}$ Department of Food Hygiene and Technology, University of León, Spain. 2 Instituto de \\ Productos lácteos de Asturias (IPLA-CSIC), Villaviciosa, Asturias, Spain
}

Food Microbiology, 2018 (Accepted; doi: 10.1016/j.fm.2018.09.003)

\begin{abstract}
Consumer demand for health-promoting foods is generating the need to develop biofunctional dairy products. Lactic acid bacteria are employed in cheese-making and some of them are able to produce beneficial compounds on human health such as $\mathrm{\gamma}$ aminobutyric acid (GABA) and ornithine but also to synthetize biogenic amines. The aim was to investigate the effect of four selected autochthonous cultures on the free amino acid profile, with special emphasis on GABA and ornithine, and on the biogenic amine content of pasteurized sheep milk cheese during ripening. High average concentrations of GABA (1296.75 mg/kg cheese) and ornithine $(2355.76 \mathrm{mg} / \mathrm{kg}$ cheese) were found in all the cheese batches at 240 days of ripening. Batch 2, manufactured with the culture containing autochthonous Lactococcus lactis strains as starter and Lactobacillus plantarum TAUL1588 as adjunct, showed 2.37 fold reduced biogenic amines concentration with respect to the batch 1 made with the starter during the ripening time. The microstructure and microbiological counts of cheeses were affected $(P \leq 0.001)$ by the ripening time, without appreciating differences $(P>0.05)$ in the physico-chemical composition between batches. This study could be a good approach to the development of functional sheep milk cheese.
\end{abstract}





\section{INTRODUCTION}

The relationship between food and consumer health has become a priority concern in food production. Balthazar et al. (2017) have stated that sheep milk, which is mainly used for cheese production, is an excellent source of nutrients. At present, the hygienic quality of cheese is guaranteed by the pasteurization of milk. This thermal treatment causes the elimination of part of the milk's microbiota and this fact makes necessary the use starters and adjunct cultures to guaranteeing the appropriate sensory characteristics of each cheese variety (Minervini et al., 2009). Lactic acid bacteria (LAB) are usually employed as cultures for cheese-making and play a very important role in the proteolysis that takes place during cheese ripening since they contain proteinases and peptidases that can lead to the production of free amino acids (Fox et al., 2016). Several studies have been carried out to study the effect of different autochthonous LAB strains on the content of free amino acids in cheese (Madrau et al., 2006; Mangia et al., 2008; Poveda et al., 2015, 2004). These free amino acids can act as substrates for secondary catabolic reactions by $\mathrm{LAB}$, leading to the formation of compounds such as gamma-aminobutyric acid (GABA) and ornithine (Manca et al., 2015). These two compounds have recently attracted the attention of the food industry since GABA and ornithine have numerous beneficial physiological functions on human health (Adeghate and Ponery, 2002; Diana et al., 2014a; Sugino et al., 2008).

It has been observed that various strains of LAB, such as Lactobacillus brevis DPC6108, Lb. brevis PM17, Lactobacillus plantarum C48, Lactobacillus paracasei PF6 and Lactococcus lactis PU1, were able to synthesize GABA when they are grown in culture medium supplemented with monosodium glutamate (Barrett et al., 2012; Siragusa et al., 2007). It has been also observed that the capacity to synthesize GABA by LAB is dependent on the strain and not on the specie (Dhakal et al., 2012). Several studies have been carried out in order to know the concentration of this bioactive compound in commercial cheeses (Diana et al., 2014b; Manca et al., 2015; Poveda et al., 2016). However, as Diana et al. (2014b) have indicated little attention has been given to ornithine. Likewise, few studies have been focused on testing the ability of autochthonous LAB cultures to produce GABA and ornithine during cheese making (Poveda et al., 2004; Poveda, Chicón, \& Cabezas, 2015).

However, it must be taken into account that some decarboxylation reactions can lead to toxic compounds such as biogenic amines that can also be synthesized during cheese ripening. Biogenic amines are organic, basic, nitrogenous compounds with biological activity. The consumption of foods containing large amounts of these amines can provoke toxicological effects and these problems can be more severe in consumers in whom detoxification is less efficient because of their genetic constitution or if they are under some treatments (Linares et al., 2011). Cheese is one of the most prevalent foods associated with amine poisoning and the consumption of cheese that has a high level of tyramine may result in a dangerous intoxication characterized by an increase in blood pressure (Ladero et al., 2010). For this reason, when cultures are designed to be employed in the production of cheese with an amino acid profile beneficial on human health, it is also necessary to ensure that these cultures do not generate high concentrations of biogenic amines in the final product. 
The objective of this study was to investigate the effect of the use of four different autochthonous cultures on the free amino acid profile, with special emphasis on GABA and ornithine, on the biogenic amine content, microstructure, physico-chemical and microbiological parameters of pasteurized sheep milk cheese during ripening.

\section{MATERIAL AND METHODS}

\section{Preparation of cultures}

The autochthonous cultures used in sheep cheese manufacture were selected based on their good technological aptitude showed in previous studies (González et al., 2015; Herreros et al., 2003).

Before culturing, each LAB strain was activated in either MRS broth (Oxoid, Hampshire, UK) for Lactobacillus or Elliker broth (BD Difco, New Jersey, USA) for Lactococcus lactis, and then in reconstituted skim milk $(10 \%, \mathrm{w} / \mathrm{v})$ at $30^{\circ} \mathrm{C}$ for $24 \mathrm{~h}$. The strain composition of the designed cultures for cheese manufacture is shown in Figure $\mathbf{1}$. Finally, each activated autochthonous cultures were transferred at $1 \%(\mathrm{v} / \mathrm{v})$ to sterilized sheep milk and incubated for $48 \mathrm{~h}$ at $30^{\circ} \mathrm{C}$.

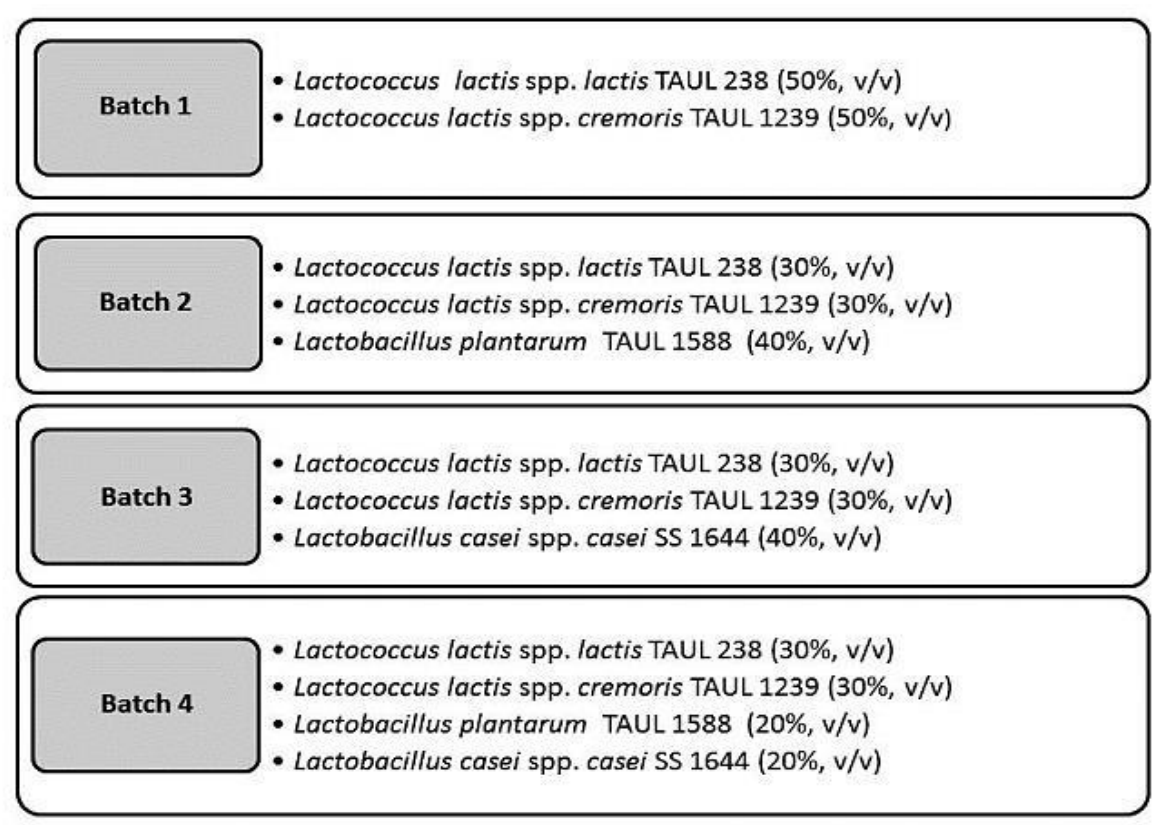

Figure 1. Strain composition of the autochthonous cultures. Volume of each individual strain cultured in milk respect to the final volume of the mixed culture in sheep milk. 


\section{Milk and cheese manufacture}

Sheep milk was obtained over four consecutive days from a local farm which belongs to the Consortium for Ovine Promotion (Villalpando, Zamora, Castilla-León, Spain).

Four sheep cheese batches were manufactured in duplicate at pilot scale (Institute of Food Science and Technology (ICTAL), University of León, Spain) according to the following method: $75 \mathrm{~L}$ of sheep milk (for each batch and replicate) was pasteurized at $72^{\circ} \mathrm{C}$ for $15 \mathrm{~s}$ and after cooling at $31^{\circ} \mathrm{C}$, calcium chloride $(0.2 \mathrm{~g} / \mathrm{L})$ and starter culture or starter culture plus adjunct $(1 \%, v / v)$ were added. The composition of the cultures used for each cheese batch is indicated in Figure 1. After $30 \mathrm{~min}$, chymosin (CHY-MAX Extra, $100 \%$ chymosin; $600 \mathrm{IMCU} / \mathrm{mL}$; Chr. Hansen SL, Madrid, Spain) was added at a rate of 0.05 $\mathrm{mL} / \mathrm{L}$ of milk (diluted in 1:20 with deionized water). After 40-45 min, the curd was cut to rice grain size and the whey was drained off. The curd was transferred to cylindrical molds (15 cm height, $21 \mathrm{~cm}$ diameter) which were pressed for $2 \mathrm{~h}$. Then, cheeses were salted by immersion $\left(18^{\circ}\right.$ Baume, $8^{\circ} \mathrm{C}$ and $\left.\mathrm{pH} 5.4\right)$ for $17 \mathrm{~h}$. Finally, the cheeses without being packaged were taken to a ripening chamber where they remained at a temperature of $10^{\circ} \mathrm{C}$ and at $80-85 \%$ relative humidity for $240 \mathrm{~d}$.

Samples were taken from each batch after 2, 90, 180 and 240 days of ripening. The samples (each sample corresponded to a whole cheese of $2.5 \mathrm{~kg}$ ) were grinded, packed and stored in a freezer $\left(-30^{\circ} \mathrm{C}\right)$ until analysis. Microstructure, physico-chemical and microbiological analyses were carried out on fresh samples.

\section{Physico-chemical analysis}

The $\mathrm{pH}$ and titratable acidity of cheese batches were determined according to standard 14.022 (AOAC, 1980a, 1980b). Water activity $\left(A_{w}\right)$ was analyzed instrumentally using an Aqua Lab Dew Point Analyzer CX-2 (Decagon Devices, Pullman, WA, USA). Total solids, $\mathrm{NaCl}$, fat and protein contents were determined according to standards 004 (FILIDF, 2004), 935.43 (AOAC, 1990), 221 (FIL-IDF, 2008), 20-1 (FIL-IDF, 2001), respectively. All samples were carried out in duplicate.

\section{Microbiological analysis}

Fifty grams of milk or cheese samples were homogenized with $200 \mathrm{~mL}$ of a $2 \%(\mathrm{w} / \mathrm{v})$ sodium citrate solution (Panreac, Barcelona, Spain) in a Stomacher 400 Lab Blender (Seward Medical, London, UK). Decimal dilutions were prepared by mixing $10 \mathrm{~mL}$ of this homogenate with $90 \mathrm{~mL}$ of sterile peptone water (Oxoid, Unipath, Ltd., Basingstoke, UK) at $0.1 \%(\mathrm{w} / \mathrm{v})$ according to standard 122B (FIL-IDF, 1992).

Aerobic mesophilic bacteria were enumerated on standard Plate Count Agar (PCA; Oxoid) after incubation at $30^{\circ} \mathrm{C}$ for $48 \mathrm{~h}$. LAB were determined on De Man-Rogosa-Sharpe (MRS) agar (Oxoid) after incubation at $30^{\circ} \mathrm{C}$ for $72 \mathrm{~h}$. Lactobacilli were enumerated on Rogosa agar (Oxoid) incubated at $30^{\circ} \mathrm{C}$ during 5 days. Enterobacteriaceae were enumerated on Violet Red Bile Glucose Agar (VRBGA; Oxoid) after incubation at $37^{\circ} \mathrm{C}$ for $18-24 \mathrm{~h}$. 


\section{Determination of free amino acids and biogenic amines by ultra-high performance liquid chromatography}

Free amino acids and biogenic amines were determined following the method described by Redruello et al. (2013). Briefly, amino acids and biogenic amines were extracted by the homogenization of one gram of cheese in $10 \mathrm{~mL}$ of $0.1 \mathrm{M} \mathrm{HCl}-0.2 \%$ 3,3 thiodipropionic acid (Sigma-Aldrich, Madrid, Spain). This mixture was kept in an ultrasonic bath Bransonic 221 (Branson Ultrasonics S.A, Danbury, USA) for $30 \mathrm{~min}$ and then centrifuged at $5000 \times \mathrm{g}$ for $20 \mathrm{~min}$. The supernatant was deproteinised by passing through ultrafiltration inserts (Amicon Biomax 5K; Millipore, MA, USA) by centrifugation at $3500 \times g$ for $1 \mathrm{~h} .20 \mu \mathrm{L}$ of this diluted sample were derivatised with diethyl ethoxymethylenemalonate (DEEMM; Sigma-Aldrich). Duplicate samples were freshly derivatised before injection in the chromatograph system. L-2-aminoadipicacid (SigmaAldrich) was used as internal standard. The chromatograph system consisted of an $\mathrm{H}$ Class Acquity UPLC ${ }^{\mathrm{TM}}$ system (Waters, Milford, MA, USA) coupled to a photodiode array detector. Free amino acids and biogenic amines separation was carried out using a Waters Acquity UPLC ${ }^{\mathrm{TM}} \mathrm{BEH} \mathrm{C} 18$ column $(1.7 \mu \mathrm{m}$ particle size, $100 \mathrm{~mm} \times 2.1 \mathrm{~mm}$ I.D. $)$ held at $35^{\circ} \mathrm{C}$. The mobile phase consisted of $25 \mathrm{mM}$ acetate buffer $\mathrm{pH} 6.7$ plus $0.02 \%$ sodium azide (eluent A), methanol (eluent B) and acetonitrile (eluent C). Samples (1 $\mu \mathrm{L})$ were applied to the column and eluted at a flow rate of $0.45 \mathrm{~mL} / \mathrm{min}$ according to the linear gradient used by Redruello et al. (2013). The target compounds were identified by their retention times and their spectral characteristics at $280 \mathrm{~nm}$, and were quantified using the internal standard method. Data were acquired and analyzed using the software Empower 2 (Waters, Milford, MA, USA).

\section{Confocal scanning laser microscopy (CSLM)}

The four sheep cheese batches were examined using CSLM at 2, 90, 180 and 240 days of ripening, as described by Auty et al. (2001), in order to visualize the changes that took place in the distributions and microstructures of the fat and protein. Cheese sample measuring $10 \mathrm{~mm} \times 10 \mathrm{~mm} \times 5 \mathrm{~mm}$ was stained with $50 \mathrm{~L}$ of a probe mixture constituted by Nile Red (Sigma-Aldrich) $0.02 \mathrm{~g} / \mathrm{L}$ and Fast Green FCF (Sigma-Aldrich) $0.1 \mathrm{~g} / \mathrm{L}$ and examined using a Zeiss LSM310 confocal laser scanning microscope (Carl Zeiss, Welwyn Garden City, Herts, UK). Dual excitation using $488 \mathrm{~nm} / 633 \mathrm{~nm}$ for Nile Red/Fast Green FCF was used.

\section{Statistical analysis}

Statistical analysis of the experimental data was performed using SPSS v.21 (SPSS, Chicago, IL, USA). The free amino acids, biogenic amines, physico-chemical and microbiological variables were tested for the assumption of normality using the ShapiroWilk test and for homoscedasticity using the Levene test. Subsequently, a two-way Analysis of Variance (ANOVA) was performed in order to evaluate the effect of the factors culture and ripening time (as fixed factors) and the interaction between them. Tukey's HSD post hoc test was applied at a 5\% significance level in order to compare sheep cheeses manufactured with different autochthonous cultures throughout the different ripening times. The Spearman's rank correlation coefficient $(\rho)$ was applied to estimate the 
relationship between the physico-chemical parameters and microbiological populations of cheese samples.

\section{RESULTS AND DISCUSSION}

\section{Physico-chemical composition of sheep milk cheeses during ripening}

The changes in the physico-chemical parameters of the four sheep milk cheeses throughout ripening are shown in Table 1. These results demonstrated that the different cultures used for cheese-making did not have a statistically significant effect $(P>0.05)$ on most of the analyzed parameters at the same ripening time. Nevertheless, the titratable acidity values for the 3 and 4 batches manufactured with cultures containing the Lactobacillus casei subsp. casei SS1644 were higher than the other two cheese batches at 90 and 180 days of ripening. The greater acidifying capacity of this strain with respect to the $L b$. plantarum TAUL 1588 strain was previously reported in other studies (González et al., 2015; Herreros et al., 2003).

It is well known that during ripening a very complex set of interrelated biochemical processes happen and they are responsible of cheese characteristics (Fox et al., 2016).

The evolution of the physico-chemical parameters analyzed during the ripening time enabled an understanding that the process of cheese-making for the 4 batches of cheese was similar. At the beginning of ripening (2 days), there was an increase in $\mathrm{pH}$ until 90 days to subsequently remain constant or decrease slightly. The increase observed in the values of this parameter could be due mainly to the buffer capacity that can present the cheese curd during the ripening process (Salaün et al., 2005). This fact prevents obtaining information on microbial growth, however, a clear indicator of the metabolic activity of the cultures used in the cheese-making was the increase of the titratable acidity values until 180 days of ripening to later descend. Moreover, the acidification that took place during the ripening process of the cheese batches contributed to the internal drying of the cheese. A significant negative correlation was found between acidity and moisture values $(\rho=-$ $0.84 ; P \leq 0.01)$. Moisture decreased significantly $(P \leq 0.001)$ throughout ripening, reaching values lower than $30 \%$. $A_{w}$ followed a similar trend, the mean values decreased as ripening progressed, from 0.989 to 0.915 at the end of the ripening period. It was observed that as the salt/moisture ratio increased, $A_{w}$ values decreased $(\rho=-0.87 ; P \leq 0.01)$. Guinee (2004) has described that salt is a major determinant of the $A_{w}$ parameter, and thereby exerts control over microbial growth, enzyme activity, and biochemical changes during cheese ripening. The salt/moisture ratio initially increased up to 180 days of ripening to finally remain constant, reaching a value of around $5 \%$ in all cheese batches. These $A_{w}$ and salt/moisture values were similar to those described by other authors for ripened sheep milk cheeses (Guinee and Fox, 2004).

During the ripening period no significant $(P>0.05)$ differences were observed in fat and protein in dry matter contents. The values obtained were comparable with those described by other authors for sheep milk cheese (Fernández et al., 2012). 
Table 1. Changes in $\mathrm{pH}$, titratable acidity, water activity $\left(\mathrm{A}_{\mathrm{w}}\right)$ values and in moisture, salt/moisture, fat and protein contents of four sheep milk cheese batches.

\section{Physico-chemical}

parameter

$\mathrm{pH}$

Titratable acidity total solids)

$\mathrm{A}_{\mathrm{W}}$

Moisture

(g/kg cheese)

Salt/moisture

(g salt/kg

moisture)

Fat
(g/kg total solids)

3

Protein

(g/kg total solids) (g lactic acid/kg

\section{Batch}

1

2
3

4

1
2
3

3

4

1

1
2
3
4

1
2
3
4

$43 \pm 8.36^{a}$

$399.09 \pm 10.61^{a}$

$15.08 \pm 0.40^{\mathrm{a}}$
$16.20 \pm 0.17^{\mathrm{a}}$
$15.89 \pm 0.33^{\mathrm{a}}$

$15.89 \pm 0.33^{\mathrm{a}}$
$16.11 \pm 0.43^{\mathrm{a}}$

$551.32 \pm 3.35^{\mathrm{a}}$ $550.52 \pm 2.60^{\mathrm{a}}$ $550.47 \pm 5.37^{\mathrm{a}}$ $549.73 \pm 5.35^{\mathrm{a}}$

$344.55 \pm 3.40^{\mathrm{a}}$ $344.47 \pm 2.26^{\mathrm{a}}$ $345.10 \pm 2.38^{\mathrm{a}}$ $344.97 \pm 2.13^{\mathrm{a}}$
$409.55 \pm 4.39$

\section{Ripening time (days)}

90

$5.32 \pm 0.05^{a}$

$5.28 \pm 0.02^{\mathrm{a}}$

$5.34 \pm 0.03^{\mathrm{a}}$

$5.31 \pm 0.01^{\mathrm{a}}$

$17.50 \pm 0.50^{\mathrm{a}}$

$17.95 \pm 0.15^{\mathrm{a}}$

$20.61 \pm 1.45^{\mathrm{b}}$

$20.11 \pm 0.67^{\mathrm{b}}$

$0.966 \pm 0.001^{\mathrm{a}}$

$0.968 \pm 0.000^{\mathrm{a}}$

$0.965 \pm 0.001^{\mathrm{a}}$

$0.970 \pm 0.001^{\mathrm{a}}$

$337.79 \pm 4.21^{\mathrm{a}}$

$341.35 \pm 1.71^{\mathrm{a}}$

$338.87 \pm 1.57^{\mathrm{a}}$

$340.22 \pm 2.41^{\mathrm{a}}$

$43.38 \pm 0.11^{\mathrm{a}}$

$43.42 \pm 0.12^{\mathrm{a}}$

$43.07 \pm 0.38^{a}$

$43.16 \pm 0.17^{\mathrm{a}}$

$555.20 \pm 2.70^{a}$

$554.86 \pm 1.14^{\mathrm{a}}$

$555.40 \pm 1.71^{\mathrm{a}}$

$555.05 \pm 2.99$ a

$338.23 \pm 4.53^{\mathrm{a}}$

$338.02 \pm 3.41^{\mathrm{a}}$

$338.75 \pm 3.41^{\mathrm{a}}$
$338.75 \pm 3.41^{\circ}$
$33.30^{a}$
180

$5.33 \pm 0.01^{\text {a }}$

$5.31 \pm 0.01^{\mathrm{a}}$

$5.29 \pm 0.01^{\mathrm{a}}$

$5.29 \pm 0.01^{\mathrm{a}}$

$22.44 \pm 0.52^{\mathrm{a}}$

$22.83 \pm 0.52^{\mathrm{a}}$

$23.90 \pm 0.10^{\mathrm{b}}$

$23.42 \pm 0.42^{b}$

$0.945 \pm 0.001^{\mathrm{a}}$

$0.944 \pm 0.001^{\mathrm{a}}$

$0.938 \pm 0.000^{\mathrm{a}}$

$0.940 \pm 0.000^{\mathrm{a}}$

$286.15 \pm 0.44^{\mathrm{a}}$

$296.58 \pm 1.41^{\mathrm{a}}$

$288.03+4.89$

$297.30 \pm 5.97 \mathrm{a}$

$54.15 \pm 0.39^{a}$

$54.66 \pm 1.20^{\mathrm{a}}$

$54.02 \pm 0.65^{\mathrm{a}}$

$54.50 \pm 0.70^{\mathrm{a}}$

$555.22 \pm 5.06^{\mathrm{a}}$ $553.90 \pm 6.17^{\mathrm{a}}$

$555.46 \pm 5.06^{\mathrm{a}}$

$554.21 \pm 6.01^{\mathrm{a}}$

$347.60 \pm 3.54^{\mathrm{a}}$ $348.26 \pm 4.41^{\mathrm{a}}$

$348.51 \pm 4.31^{\mathrm{a}}$ $348.92 \pm 4.16^{\mathrm{a}}$

\section{0}

$5.30 \pm 0.02^{a}$

$5.30 \pm 0.01^{\mathrm{a}}$

$5.28 \pm 0.01^{\mathrm{a}}$

$5.26 \pm 0.01^{\mathrm{a}}$

$20.88 \pm 0.33^{a}$

$20.45 \pm 0.54^{a}$

$21.17 \pm 0.21^{a}$

$21.31 \pm 0.33^{a}$

$0.913 \pm 0.001^{\mathrm{a}}$

$0.917 \pm 0.001^{\mathrm{a}}$

$0.912 \pm 0.001^{\mathrm{a}}$

$0.918 \pm 0.000^{\mathrm{a}}$

$281.04 \pm 3.52^{\mathrm{a}}$

$278.46 \pm 1.72^{\mathrm{a}}$

$279.73 \pm 0.30^{\mathrm{a}}$

$280.24 \pm 0.30^{a}$

$53.23 \pm 0.20^{a}$

$53.93 \pm 0.81^{\mathrm{a}}$

$53.34 \pm 0.10^{a}$

$53.87 \pm 0.61^{\mathrm{a}}$

$555.19 \pm 2.01^{\mathrm{a}}$

$552.97 \pm 1.06^{\mathrm{a}}$

$555.47 \pm 2.12^{\mathrm{a}}$

$554.32 \pm 3.35^{\mathrm{a}}$

$348.88 \pm 3.21^{\mathrm{a}}$

$348.96 \pm 5.11^{\mathrm{a}}$

$349.01 \pm 4.35^{\mathrm{a}}$

$349.06 \pm 5.14^{\mathrm{a}}$
$P$-value ${ }^{2}$

B

NS

NS

NS

NS

NS

NS

* NS NS

1: Lactococcus lactis subsp. lactis TAUL $238+$ Lactococcus lactis subsp. cremoris TAUL 1239; 2: starter 1 + Lactobacillus

casei subp. casei SS 1644; 4: starter 1 + Lactobacillus plantarum TAUL 1588 + Lactobacillus casei subp. casei SS 1644.

Results expr. caseiss 1644; 4: starter $1+$ Lactobacillus plantarum TAUL $1588+$ Lactobacillus casei subp. casei SS 1644 . cheese batches. ${ }^{2} \mathrm{R}$ : ripening time fixed effect; $\mathrm{B}$ : batch fixed effect; $\mathrm{R}^{*} \mathrm{~B}$ : interaction between the fixed effects. NS $P>0.05 ;{ }^{*} P \leq 0.05 ;{ }^{* *} P \leq 0.01 ;{ }^{* * *} P \leq 0.001$. 
Table 2. Changes in microbial counts $(\log \mathrm{CFU} / \mathrm{mL})$ of the four sheep milk cheese batches throughout ripening.

\begin{tabular}{|c|c|c|c|c|c|c|c|c|c|}
\hline \multirow{2}{*}{ Microbial group } & \multirow[b]{2}{*}{ Batch1 } & \multirow[b]{2}{*}{ Milk2 $^{2}$} & \multicolumn{4}{|c|}{ Ripening time (days) } & \multicolumn{3}{|c|}{ P-value $^{3}$} \\
\hline & & & 2 & 90 & 180 & 240 & $\mathbf{R}$ & $\mathbf{B}$ & $\mathbf{R}^{*} \mathbf{B}$ \\
\hline \multirow[t]{4}{*}{ Aerobic mesophilic microbiota } & 1 & $6.80 \pm 0.96^{a}$ & $9.55 \pm 0.04^{a}$ & $7.31 \pm 0.04^{a}$ & $7.17 \pm 0.11^{\mathrm{a}}$ & $7.17 \pm 0.12^{\mathrm{a}}$ & $* * *$ & $* * *$ & $* * *$ \\
\hline & 2 & $7.18 \pm 0.11^{\mathrm{a}}$ & $9.68 \pm 0.53^{b}$ & $8.74 \pm 0.28^{b}$ & $7.97 \pm 0.14^{b}$ & $7.84 \pm 0.42^{\mathrm{b}}$ & $* * *$ & $* * *$ & $* * *$ \\
\hline & 3 & $7.13 \pm 0.07^{a}$ & $9.19 \pm 0.10^{c}$ & $10.92 \pm 0.25^{c}$ & $9.19 \pm 0.11^{\mathrm{c}}$ & $8.98 \pm 0.11^{\mathrm{c}}$ & $* * *$ & $* * *$ & $* * *$ \\
\hline & 4 & $7.36 \pm 0.22^{\mathrm{a}}$ & $9.59 \pm 0.27^{a}$ & $8.95 \pm 0.35^{d}$ & $8.47 \pm 0.04^{\mathrm{d}}$ & $8.33 \pm 0.04^{d}$ & $* * *$ & $* * *$ & $* * *$ \\
\hline \multirow[t]{4}{*}{ Lactic acid bacteria } & 1 & $6.87 \pm 0.52^{\mathrm{a}}$ & $7.50 \pm 0.18^{a}$ & $7.36 \pm 0.18^{a}$ & $7.03 \pm 0.18^{a}$ & $6.71 \pm 0.18^{a}$ & $* * *$ & $* * *$ & ** \\
\hline & 2 & $7.14 \pm 0.12^{\mathrm{a}}$ & $9.77 \pm 0.41^{b}$ & $8.73 \pm 0.18^{b}$ & $7.74 \pm 0.07^{b}$ & $7.65 \pm 0.27^{b}$ & $* * *$ & $* * *$ & $* *$ \\
\hline & 3 & $7.10 \pm 0.05^{a}$ & $9.20 \pm 0.05^{c}$ & $8.87 \pm 0.37^{b}$ & $8.89 \pm 0.07^{c}$ & $8.75 \pm 0.07^{c}$ & $* * *$ & $* * *$ & $* *$ \\
\hline & 4 & $7.38 \pm 0.10^{a}$ & $9.70 \pm 0.11^{b}$ & $8.83 \pm 0.18^{b}$ & $8.36 \pm 0.28^{\mathrm{d}}$ & $8.24 \pm 0.20^{d}$ & $* * *$ & $* * *$ & $* *$ \\
\hline \multirow[t]{4}{*}{ Lactobacilli } & 1 & - & - & - & $3.40 \pm 0.20^{\mathrm{a}}$ & $2.40 \pm 0.10^{a}$ & $* * *$ & $* * *$ & $* * *$ \\
\hline & 2 & $5.99 \pm 0.04^{a}$ & $7.93 \pm 0.81^{\mathrm{a}}$ & $8.71 \pm 0.07^{a}$ & $7.95 \pm 0.78^{b}$ & $7.54 \pm 0.35^{\mathrm{b}}$ & $* * *$ & $* * *$ & $* * *$ \\
\hline & 3 & $5.40 \pm 0.04^{a}$ & $9.28 \pm 0.17^{\mathrm{b}}$ & $7.60 \pm 0.36^{b}$ & $7.22 \pm 0.13^{c}$ & $7.03 \pm 0.20^{c}$ & $* * *$ & $* * *$ & $* * *$ \\
\hline & 4 & $7.30 \pm 0.07^{\mathrm{b}}$ & $7.77 \pm 0.42^{c}$ & $8.70 \pm 0.25^{a}$ & $7.80 \pm 0.22^{\mathrm{d}}$ & $6.83 \pm 0.15^{d}$ & $* * *$ & $* * *$ & $* * *$ \\
\hline \multirow[t]{4}{*}{ Enterobacteriaceae } & 1 & - & $3.52 \pm 0.22^{\mathrm{a}}$ & - & - & - & $* * *$ & $* * *$ & $* * *$ \\
\hline & 2 & $2.58 \pm 0.50$ & $3.57 \pm 0.27^{a}$ & - & - & - & $* * *$ & $* * *$ & $* * *$ \\
\hline & 3 & - & $3.98 \pm 0.71^{\mathrm{a}}$ & - & - & - & $* * *$ & $* * *$ & $* * *$ \\
\hline & 4 & - & $2.77 \pm 0.35^{b}$ & - & - & - & $* * *$ & $* * *$ & $* * *$ \\
\hline
\end{tabular}

11: Lactococcus lactis subsp. lactis TAUL $238+$ Lactococcus lactis subsp. cremoris TAUL 1239; 2: starter 1 + Lactobacillus plantarum TAUL 1588; 3: starter 1 + Lactobacillus casei subp. casei SS 1644; 4: starter 1 + Lactobacillus plantarum TAUL 1588 + Lactobacillus casei subp. casei SS 1644

Results expressed as mean values \pm standard deviation, $\mathrm{n}=2$.

a-d Different superscript letters in the same column denote significant statistical differences $(P \leq 0.05)$ between cheese batches.

2Pasteurized milk + each culture $(0 \mathrm{~h})$.

${ }^{3} \mathrm{R}$ : ripening time fixed effect; $\mathrm{B}$ : batch fixed effect; $\mathrm{R} * \mathrm{~B}$ : interaction between the fixed effects. ${ }^{* *} P \leq 0.01 ;{ }^{* * *} P \leq 0.001$.

Table 3. Total free amino acid concentration (mg/kg cheese) in the sheep milk cheeses manufactured with different cultures throughout ripening.

\begin{tabular}{|c|c|c|c|c|c|c|c|}
\hline \multirow{2}{*}{$\begin{array}{c}\text { Ripening } \\
\text { time } \\
\text { (days) }\end{array}$} & \multicolumn{4}{|c|}{ Batch1 } & \multicolumn{3}{|c|}{ P-value 2 } \\
\hline & 1 & 2 & 3 & 4 & B & $\mathbf{R}$ & $\mathbf{B}^{*} \mathbf{R}$ \\
\hline 2 & $4924.12 \pm 53.59^{a}$ & $4530.12 \pm 49.23^{\mathrm{b}}$ & $5910.09 \pm 53.17^{c}$ & $4760.68 \pm 46.64^{a}$ & $* * *$ & $* * *$ & $* * *$ \\
\hline 90 & $16877.92 \pm 170.46^{a}$ & $16687.85 \pm 158.53^{a}$ & $40320.11 \pm 450.44^{b}$ & $16978.97 \pm 187.61^{a}$ & $* * *$ & $* * *$ & $* * *$ \\
\hline 180 & $34563.46 \pm 307.75^{a}$ & $34763.36 \pm 360.19^{a}$ & $79662.49 \pm 771.78^{\mathrm{b}}$ & $38414.89 \pm 414.78^{a}$ & $* * *$ & $* * *$ & $* * *$ \\
\hline 240 & $44671.13 \pm 478.42^{\mathrm{a}}$ & $42076.23 \pm 451.02^{a}$ & $87623.26 \pm 928.00^{\mathrm{b}}$ & $49083.01 \pm 473.76^{c}$ & $* * *$ & $* * *$ & $* * *$ \\
\hline
\end{tabular}

11: Lactococcus lactis subsp. lactis TAUL $238+$ Lactococcus lactis subsp cremoris TAUL 1239; $2 \cdot$ starter $1+$ Lactobacillu casei subp casei SS 1644; 4: starter 1 + Lactobacillus plantarum TAUL 1588 + Lactobacillus casei subp. casei SS 1644.

Results as mean values \pm standard deviation, $n=4$. a-d Different lowercase superscript letters in a same row denote significant statistical differences $(P \leq 0.05)$ between cheese batches. ${ }^{2}$ B: batch fixed effect; R: ripening time fixed effect; $B^{*}$ R: interaction between the fixed effects. ${ }^{* * *} P \leq 0.001$. 


\section{Microbial populations of sheep milk cheeses during ripening}

The changes in the microbial counts of the four cheese batches throughout the ripening time are reported in Table 2. The aerobic mesophilic microbiota, lactic acid bacteria and lactobacilli counts increased significantly $(P \leq 0.001)$ from the pasteurized milk inoculated with each culture $(0 \mathrm{~h})$ until the initial stage of ripening. Diezhandino et al. (2015) indicated that this increase in counts is due to the physical retention of microorganisms in curds and to microbial multiplication during the coagulation phase of cheese-making.

The highest counts for aerobic mesophilic microbiota were observed at 2 days of ripening (10 $\log \mathrm{CFU} / \mathrm{mL}$ ), except for batch 3 , in which the maximum counts were detected at 90 days $(11 \log \mathrm{CFU} / \mathrm{mL}$ ). From this point, aerobic mesophilic bacteria gradually decreased towards the end of the ripening with values ranging 7 (batch 1) and 9 (batch 3) $\log$ units.

The lactic acid bacteria counts throughout the ripening period were similar to those observed in the mesophilic aerobic microbiota, which reflects that the lactic acid bacteria were the predominant microorganisms in the four sheep cheese batches. There was a significant negative correlation between lactic acid counts and the salt/moisture ratio $(\rho=$ -0.57; $P \leq 0.01$. Lactic acid bacteria counts increased until 2 days, after which they decreased approximately 1-2 log $\mathrm{CFU} / \mathrm{mL}$ until the end of the ripening time. The large increase in salt/moisture ratio values at 90 days (Table 1) could exert an inhibitory effect on the lactic acid bacteria growth.

Lactobacilli are considered as non-starter lactic acid bacteria (NSLAB) which dominate cheese microbiota during ripening. They tolerate the hostile environment well and strongly influence the biochemistry of curd ripening, contributing to the development of the final characteristics of cheese (Settanni and Moschetti, 2010). In the batches 2 and 4, which were the batches that included in the culture the Lb. plantarum TAUL 1588 strain, the highest counts were observed at 90 days while in the batch 3 manufactured with the culture that included the $L b$. casei subsp. casei SS1644 strain the highest counts of lactobacilli were detected after 2 days and then decreased slightly until the end of the ripening time. In batch 1, lactobacilli were not detected until 180 days of ripening and with values much lower than the other batches since it was the only batch in which no strains of Lactobacillus were included in the culture used.

The Enterobacteriaceae counts are an indicator of the hygienic conditions applied during the cheese-making. The good sanitary quality of the four batches was evidenced because Enterobacteriaceae counts were detected at 2 days of ripening with values lower than $4 \log \mathrm{CFU} / \mathrm{mL}$. It was observed a significant negative correlation between Enterobacteriaceae counts and acidity $(\rho=-0.73 ; P \leq 0.01)$ as well as with the salt/moisture ratio $(\rho=-0.95 ; P \leq 0.01)$ coinciding with that described by other authors in sheep cheese (Piras et al., 2013).

\section{Free amino acid content and microstructure of sheep milk cheeses during ripening}

The evolution of total free amino acids (TFAAs) during ripening in the four sheep milk cheeses manufactured with different cultures is shown in Table 3 . The TFAAs concentrations in all the batches increased significantly $(P \leq 0.001)$ throughout the ripening period, from $5031.25 \mathrm{mg} / \mathrm{kg}$ cheese at 2 days up to $55863.41 \mathrm{mg} / \mathrm{kg}$ cheese at 
240 days of ripening. This increase in the TFAAs concentration was mainly due to the proteolytic activity of the strains which made up the cultures (González et al., 2015; Herreros et al., 2003). The large proteolytic activity shown by the strains gave rise that the TFAA values observed in the present study were higher than those reported by Poveda et al. (2004) for sheep milk cheese manufactured with different starters and analyzed during 150 days of ripening.

The proteolysis that took place during the cheese ripening can be visually evidenced by the images (Figure 2) obtained when the microstructure of the different batches was
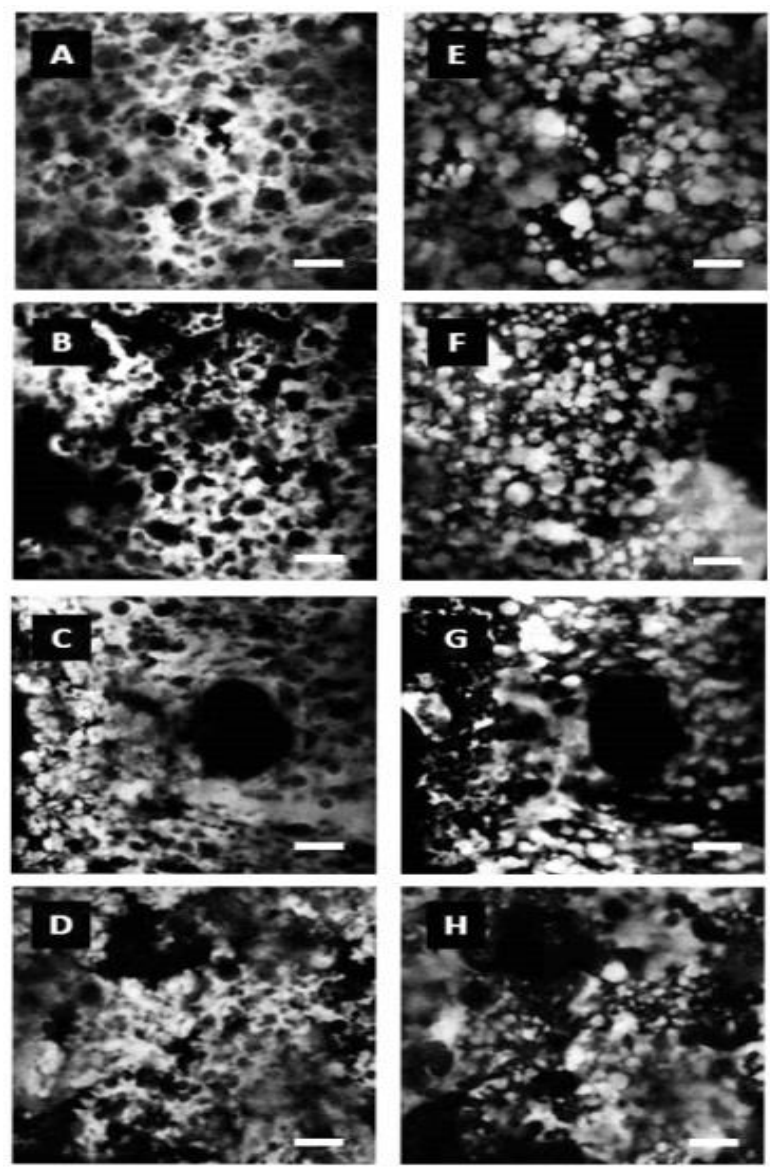

Figure 2. Confocal laser scanning images of the protein (A-D) and fat $(\mathrm{E}-\mathrm{H})$ in cheese batch 1 throughout the ripening period: 2 days (A and $\mathrm{E}), 90$ days $(\mathrm{B}$ and $\mathrm{F}), 180$ days $(\mathrm{C}$ and $\mathrm{G})$ and 240 days $(\mathrm{D}$ and $\mathrm{H})$. The protein and fat are shown as light areas against a dark background. Scale bar, $25 \mu \mathrm{m}$. analyzed using confocal laser scanning microscopy. The images of the four cheese batches were very similar. For this reason, in Figure 2 only the microstructure of batch 1 is shown at 2, 90, 180 and 240 days of ripening. At 2 days of ripening, a continuous and fibrous protein matrix containing irregularly shaped fat globules was observed (Figure $2 \mathbf{A}$ and $\mathbf{E}$ ). The fat and protein phases had a slight linear orientation as was also observed by Auty et al. (2001) in Cheedar cheese, attributing this fact to the pressing stage. As the ripening time progressed, changes in the microstructure of cheese could be observed. On the one hand, the protein matrix gradually presented an amorphous structure that could be due to the proteolysis produced by LAB during ripening (Figure 2 A-D). On the other hand, the coalescence of fat globules generated large fat particles and the lipolytic activity during ripening could contribute to the output of free fat (Figure 2 H). These results were consistent with those reported by other authors for the microstructure of cheese (Everett and Auty, 2008; O'Reilly et al., 2003). It was also shown the physical holes that were generated during ripening (Figure 2 C, D, G and H).

The different cultures used for cheese-making in the present study had a significant $(P \leq 0.001)$ effect on the TFAAs concentrations (Table 3). Batch 3 manufactured with the $L b$. casei subsp. casei SS1644 strain showed the highest TFAAs concentrations throughout the 
ripening period. After 90 days of ripening, this batch showed a TFAAs concentration similar to that shown by the other batches at the end of ripening. Azarnia et al. (2006) have indicated that ripening is a relatively expensive process for the cheese industry. Therefore, the use of this culture could reduce the ripening time of sheep milk cheese, providing technological benefits.

Batches 1,2 and 4 did not show significant differences $(P>0.05)$ in the TFAAs concentration until the end of ripening. At 240 days, batch 2 made with Lc. lactis strains plus $\mathrm{Lb}$. plantarum TAUL1588 presented a similar concentration of TFAAs to that of batch 1 made with the Lc. lactis strains. However, batch 4 manufactured with the four autochthonous strains had higher TFAAs concentration than batches 1 and 2 but lower than batch 3 .

The individual concentration of 21 free amino acids in sheep milk cheeses made with different cultures throughout the ripening period is shown in Figure 3. The concentration of most of the free amino acids studied increased significantly $(P \leq 0.001)$ during the cheese ripening. In general, the most abundant free amino acids were leucine, glutamic acid, phenylalanine, proline, alanine and valine which accounted approximately the $60 \%$ of the TFAAs. Tyrosine, histidine, glycine, tryptophan and arginine were minor free amino acids representing less than the $5 \%$ of the TFAAs. The data available on the literature about the major free amino acids and their concentration in sheep milk cheese varies widely (Madrau et al., 2006; Mangia et al., 2008; Poveda et al., 2015). This fact could be mainly due to the different lactic acid bacteria (LAB) used for cheese-making since LAB present a complex proteolytic system formed by different proteinases and peptidases depending on the LAB specie (Fox et al., 2016). As Poveda et al.(2004) have indicated the composition of the caseins is different; as1-casein has a high content of leucine, phenylalanine and valine, while $\beta$-casein has high content of proline. In addition free amino acids are released by the action of peptidases that vary among different strains. Therefore, depending on the specific substrates of the enzymes present in the proteolytic system of LAB, the type and concentration of free amino acids in cheese will be different.

The results obtained in the present study are relevant since little information is available about the effect of different autochthonous cultures on the concentration of GABA and ornithine in sheep milk cheese during ripening. GABA and ornithine have been reported as non-protein amino acids with numerous physiological functions (Diana et al., 2014b). GABA could be synthesized from L-glutamate by the glutamate decarboxylase (GAD) present in some LAB (Cotter and Hill, 2003; Lacroix et al., 2013). Milk caseins do not present GABA but they have a high content in L-glutamate (17.5\% of the TFAAs) which is released during cheese ripening and can be metabolized to GABA by the action of LAB (Hejtmánková et al., 2012). In Figure 3 it is shown that GABA concentration in the four cheese batches increased more than eighty-fold from 2 days to 240 days of ripening. The major concentration of GABA was observed at 240 days of ripening in batch 1 followed by the other three cheese batches which did no present differences $(P>0.05)$ between them. The importance of this study falls on the high concentration of GABA found in all the cheese batches at the end of the ripening time. Regarding the dose of GABA which is in the health-promoting range, it has been observed that a daily intake of $50 \mathrm{~g}$ of experimental cheese (containing $16 \mathrm{mg}$ of GABA) decreased blood pressure in humans (Pouliot-Mathieu et al., 2013). In the present study $50 \mathrm{~g}$ of batch 1 and $50 \mathrm{~g}$ of the other three batches 
would suppose $90 \mathrm{mg}$ and $60 \mathrm{mg}$ of GABA, respectively. This fact implied that small portions of these cheeses would be necessary to achieve the physiological effect indicated above.
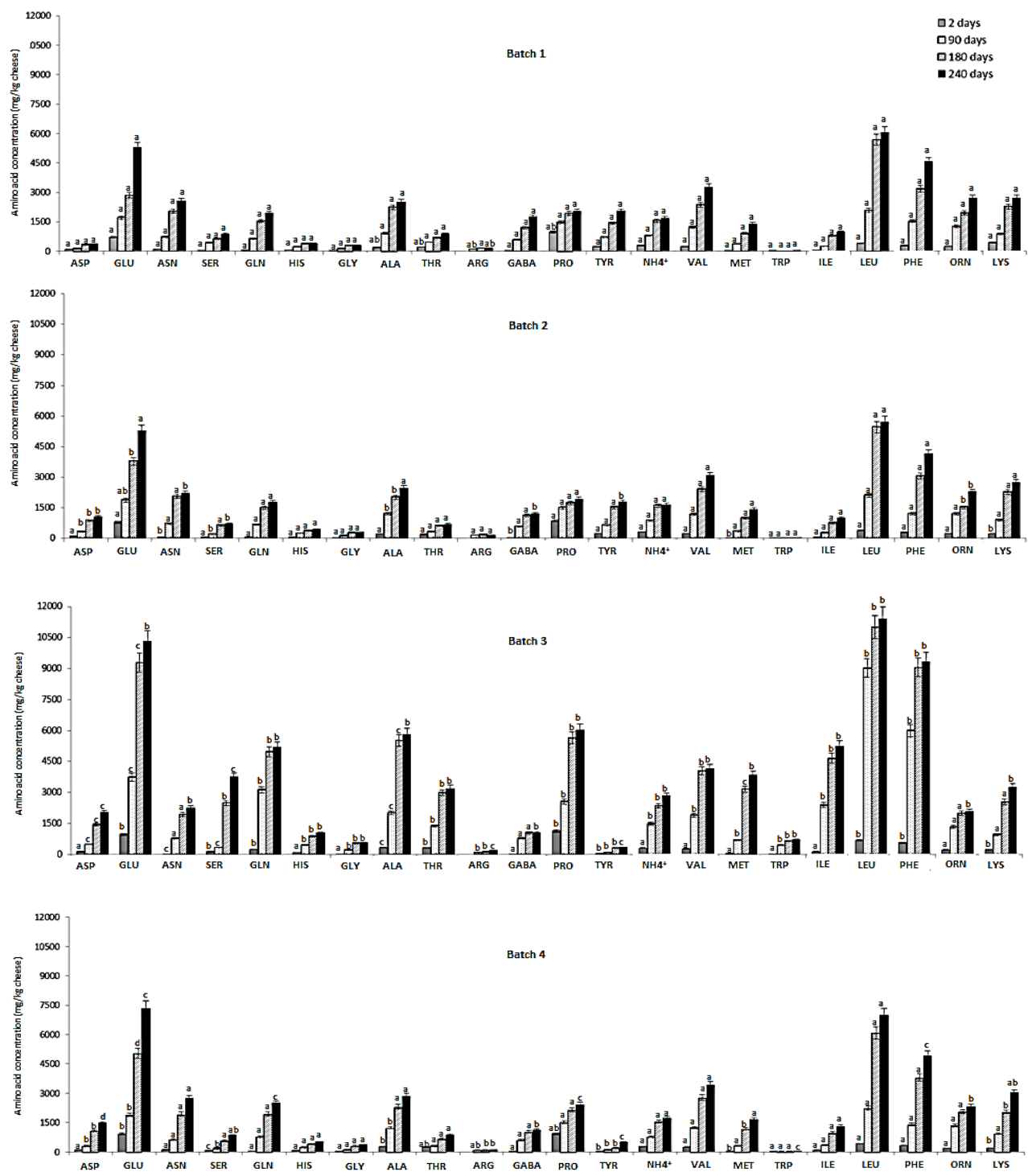

Figure 3. Evolution of the individual free amino acids during ripening of sheep milk cheese manufactured with different cultures: (Batch1) cheese made with starter composed of Lactococcus lactis subsp. lactis TAUL 238 and Lc. lactis subsp. cremoris TAUL 1239 strains; (Batch 2) cheese made with starter 1 and Lactobacillus plantarum TAUL 1588; (Batch 3) cheese made with starter 1 and Lactobacillus casei subsp. casei SS 1644; (Batch 4) cheese made with starter 1 and both Lactobacillus strains used in batches 3 and 4 .

Data represent mean \pm standard deviation (indicated by vertical error bars), $n=4$. Different letters (a-d) in the same bar of the diagram for each free amino acid in the same ripening time indicate significant statistical differences $(P \leq 0.05)$ between cheese batches.

ASP: aspartic acid; GLU: glutamic acid; ASN: asparagine; SER: serine; GLN: glutamine; HIS: histidine; GLY: glycine; ALA: alanine; THR: threonine; ARG: arginine; GABA: gamma-aminobutyric acid; PRO: proline; TYR: tyrosine; VAL: valine; METH: methionine; TRYP: tryptophan; ISOLEU: isoleucine; LEU: leucine; PHENYL: phenylalanine. ORNI: ornithine; LYS: lysine. 
Presence of ornithine in foods is gaining attention since some studies have shown its bioactive functions on human health (Kurata et al., 2012; Sugino et al., 2008). Currently, there is no information about the effective dose of ornithine to achieve the reported physiological benefits, what is known is that ornithine can be synthetized by the enzymatic activity of LAB metabolism through the precursors arginine and citrulline during cheese ripening (Diana et al., 2014b). In the four sheep milk cheeses there was an increase $(P \leq 0.001)$ in the values of ornithine throughout the ripening time. No significant $(P>0.05)$ differences were observed between the four batches analyzed until 240 days of ripening. As in the case of GABA, batch 1 was the one with the highest concentration of ornithine. Batches 2, 3 and 4 did not show differences $(P \geq 0.05)$ between them. These concentrations were higher than those (ranged between 0.40 and $1.08 \mathrm{~g} / \mathrm{kg}$ ) described by Diana et al. (2014b) for sheep milk cheeses. These results open the possibility of carrying out further studies with these co-cultures for the possible development of functional cheeses.

\section{Biogenic amines content of sheep milk cheeses during ripening}

During cheese ripening, free amino acids were generated by the autochthonous cultures studied. Some of these free amino acids can act as substrate for secondary catabolic reactions by the decarboxylase activity of LAB. The result of these metabolic routes can be other free amino acids such as GABA and ornithine which have beneficial effects on human health or biogenic amines which consumption in elevated concentrations could have negative effects on human health when the organism in not able to degrade them though the action of monoamine and diamine oxidases (Broadley, 2010; EFSA, 2011; Manca et al., 2015). For this reason, the effect of the different cultures used and the ripening time on the biogenic amines content of the cheese batches was also analyzed.

The total biogenic amines content of the sheep milk cheeses manufactured with different cultures increased significantly $(P \leq 0.001)$ during ripening, ranging between $10.17 \mathrm{mg} / \mathrm{kg}$ cheese for batch 1 at 2 days and 820.18 for batch 3 at 240 days (Table 4). These values were similar to those described for sheep milk cheeses (Renes et al., 2014; Schirone et al., 2013). The maximum permitted concentration of biogenic amines in dairy products has not been established yet from a legislative point of view. Most studies have concentrated on the study of histamine and tyramine, as these are the biogenic amines most often associated with food poisoning and the most abundant in sheep milk cheese (Linares et al., 2016). In the present study, histamine was not detected in all the cheese batches (the detection limit for histamine was $1.78 \mathrm{mg} / \mathrm{kg}$ cheese). Tyramine concentrations ranged between $308.65 \mathrm{mg} / \mathrm{kg}$ cheese and $585.47 \mathrm{mg} / \mathrm{kg}$ cheese at the end of ripening, being within the maximum tolerable limits $(100 \mathrm{mg} / \mathrm{kg}-800 \mathrm{mg} / \mathrm{kg})$ reported by ten Brink et al. (1990). Nonetheless, it is necessary to highlight that cadaverine and putrescine which have not been associated with food poisoning, may enhance the toxicity of histamine and tyramine. In this sense, the total biogenic amines content should not exceed the amount of $900 \mathrm{mg} / \mathrm{kg}$ established by Valsamaki et al. (2000). In this regard, none of the samples exceeded the indicated limit, not representing a risk to the consumer`s health. 
Table 4. Concentration (mg/kg cheese) of biogenic amines in the sheep milk cheeses manufactured with different cultures throughout ripening.

\begin{tabular}{|c|c|c|c|c|c|c|c|c|}
\hline \multirow{2}{*}{ Biogenic amine } & \multirow{2}{*}{$\begin{array}{c}\text { Ripening } \\
\text { time } \\
\text { (days) }\end{array}$} & \multicolumn{4}{|c|}{ Batch1 } & \multicolumn{3}{|c|}{ P-value $^{2}$} \\
\hline & & 1 & 2 & 3 & 4 & $\mathbf{B}$ & $\mathbf{R}$ & $\mathbf{B}^{*} \mathbf{R}$ \\
\hline \multirow[t]{4}{*}{ Tyramine } & 2 & nd & nd & $71.47 \pm 0.17^{a}$ & $44.04 \pm 0.14^{b}$ & $* * *$ & $* * *$ & $* * *$ \\
\hline & 90 & $342.95 \pm 2.13^{\mathrm{a}}$ & $274.29 \pm 1.81^{\mathrm{b}}$ & $408.60 \pm 2.05^{c}$ & $415.58 \pm 4.05^{c}$ & $* * *$ & $* * *$ & $* * *$ \\
\hline & 180 & $356.67 \pm 3.21^{\mathrm{a}}$ & $288.08 \pm 2.88^{\mathrm{b}}$ & $451.27 \pm 2.02^{c}$ & $436.09 \pm 8.69^{d}$ & $* * *$ & $* * *$ & $* * *$ \\
\hline & 240 & $493.85 \pm 2.47^{a}$ & $308.65 \pm 1.54^{\mathrm{b}}$ & $585.47 \pm 11.47^{\mathrm{c}}$ & $539.29 \pm 11.69^{d}$ & $* * *$ & $* * *$ & $* * *$ \\
\hline \multirow[t]{4}{*}{ Putrescine } & 2 & nd & nd & $8.27 \pm 0.01$ & nd & $* * *$ & ** & $* * *$ \\
\hline & 90 & nd & nd & $72.56 \pm 0.09$ & nd & $* * *$ & $* *$ & $* * *$ \\
\hline & 180 & nd & nd & $72.56 \pm 0.09$ & nd & $* * *$ & $* *$ & $* * *$ \\
\hline & 240 & nd & nd & $75.45 \pm 0.11^{\mathrm{a}}$ & $56.76 \pm 0.10^{\mathrm{b}}$ & *** & $* *$ & $* * *$ \\
\hline \multirow[t]{4}{*}{ Cadaverine } & 2 & $10.17 \pm 0.01^{\mathrm{a}}$ & $10.20 \pm 0.01^{\mathrm{a}}$ & $56.20 \pm 0.06^{\mathrm{b}}$ & $10.20 \pm 0.01^{\mathrm{a}}$ & $* * *$ & $* *$ & $* * *$ \\
\hline & 90 & $10.19 \pm 0.04^{a}$ & $10.20 \pm 0.03^{a}$ & $84.29 \pm 0.20^{b}$ & $10.21 \pm 0.01^{\mathrm{a}}$ & $* * *$ & $* *$ & $* * *$ \\
\hline & 180 & $10.33 \pm 0.02^{\mathrm{a}}$ & $10.20 \pm 0.01^{\mathrm{a}}$ & $84.47 \pm 0.20^{\mathrm{b}}$ & $10.22 \pm 0.01^{\mathrm{a}}$ & $* * *$ & $* *$ & $* * *$ \\
\hline & 240 & $10.40 \pm 0.02^{\mathrm{a}}$ & $10.21 \pm 0.01^{\mathrm{a}}$ & $89.47 \pm 0.21^{\mathrm{b}}$ & $31.65 \pm 0.31^{c}$ & $* * *$ & ** & $* * *$ \\
\hline \multirow[t]{4}{*}{ Phenylethylamine } & 2 & nd & nd & $11.99 \pm 0.01$ & nd & $* * *$ & $* *$ & $* * *$ \\
\hline & 90 & nd & nd & $60.54 \pm 0.26^{a}$ & $24.23 \pm 0.02^{\mathrm{b}}$ & $* * *$ & $* *$ & $* * *$ \\
\hline & 180 & nd & nd & $65.31 \pm 0.55^{\mathrm{a}}$ & $30.54 \pm 0.02^{\mathrm{b}}$ & *** & $* *$ & $* * *$ \\
\hline & 240 & nd & nd & $69.79 \pm 0.75^{a}$ & $45.29 \pm 0.06^{b}$ & $* * *$ & $* *$ & $* * *$ \\
\hline \multirow[t]{4}{*}{ Total } & 2 & $10.17 \pm 0.01^{\mathrm{a}}$ & $10.20 \pm 0.02^{\mathrm{a}}$ & $147.93 \pm 0.25^{\mathrm{b}}$ & $54.24 \pm 0.15^{c}$ & *** & $* * *$ & $* * *$ \\
\hline & 90 & $353.12 \pm 2.34 a$ & $284.49 \pm 1.28^{\mathrm{b}}$ & $625.99 \pm 1.27^{c}$ & $450.02 \pm 1.00^{d}$ & $* * *$ & $* * *$ & $* * *$ \\
\hline & 180 & $367.00 \pm 1.58^{a}$ & $298.28 \pm 0.47^{\mathrm{b}}$ & $673.61 \pm 1.69^{c}$ & $476.85 \pm 1.67^{d}$ & $* * *$ & $* * *$ & $* * *$ \\
\hline & 240 & $504.25 \pm 0.71^{\mathrm{a}}$ & $318.86 \pm 0.47^{b}$ & $820.18 \pm 4.00^{c}$ & $672.99 \pm 2.94^{d}$ & $* * *$ & $* * *$ & $* * *$ \\
\hline
\end{tabular}

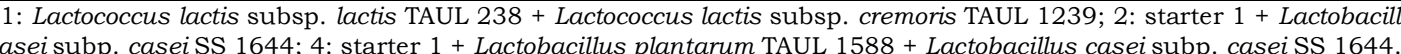

Results expressed as mean values \pm standard deviation, $\mathrm{n}=4$.

${ }^{2} \mathrm{~B}$ : batch effect; R: ripening effect; $\mathrm{B}^{*} \mathrm{R}$ : interaction batch and ripening time effect.

a-d Different lowercase superscript letters in a same row denote significant statistical differences $(P \leq 0.05)$ between cheese batches

nd: not detected; limit of detection for tyramine, putrescine and phenylethylamine was $0.86,0.41,0.26$ and $1.53 \mathrm{mg} \mathrm{kg}^{-1}$ cheese, respectively.

2 B: batch fixed effect; R: ripening time fixed effect; $\mathrm{B}^{*} \mathrm{R}$ : interaction between the fixed effects. ${ }^{* *} P \leq 0.01 ;{ }^{* * *} P \leq 0.001$ 
In Table 4, it can be observed that batch 3, manufactured with the culture containing the Lb. casei subsp. casei SS1644 strain, was the batch that presented the highest concentration of total biogenic amines throughout the ripening time. It was also the batch that had the highest concentration of TFAAs (Table 3). These results are consistent with those reported by Novella-Rodriguez et al. (2003) who indicated that an increase in cheese proteolysis during ripening could produce an increase in biogenic amines content. Batch 2 made with the Lb. plantarum TAUL1588 strain presented the lowest concentration of total biogenic amines, followed by batches 1 and 4 .

The information available about the major biogenic amines in sheep cheese is variable, as in the above-case of the TFAAs, because the type and concentration of biogenic amines found in cheese depend on the cheese variety and on the multiple factors involved in the formation and accumulation of these biogenic amines (Renes et al., 2014). The individual biogenic amines concentration in sheep milk cheese batches manufactured with different cultures during ripening are shown in Table 4.

Histamine and tryptamine were not detected in the batches examined. Tyramine resulted to be the biogenic amine in the highest concentration throughout the ripening time. At the beginning of ripening, it was not detected in batches 1 and 2 . Batch 3 was the one that showed the highest concentration of tyramine throughout the ripening time, followed by batch 4 .

Putrescine and phenylethylamine were no detected in batches 1 and 2 during ripening and in batch 4 at the beginning of ripening. Batch 3 presented the highest concentration of these amines at 2, 90, 180 and 240 days of ripening. It was observed an increase in the concentration of these amines of 9 fold for putrescine and 6 fold for phenylethylamine at 240 days of ripening with respect 2 days. As it has been described previously, some biogenic amines may cause undesirable toxicological effects. However, in the case of the phenylethylamine, it has been observed that it has beneficial physiological effects on human health (Irsfeld et al. 2013).

Batches 1 and 2 had the lowest cadaverine concentration without detecting differences $(P>0.05)$ between them. The concentration of cadaverine in these batches was not affected by the ripening time $(P>0.05)$. This same trend was observed in batch 4 until 180 days of ripening at which point the cadaverine concentration increased. Batch 3 showed the highest concentration of cadaverine during cheese ripening. The concentration of this amine increased significantly $(P \leq 0.001)$ from 2 days of ripening to 90 days, moment from which it increased slightly until the end of ripening.

\section{CONCLUSIONS}

Consumer demand for healthy foods is leading the dairy industry to develop foods in which the nutritional quality has been improved. The culture formed by autochthonous Lc. lactis subsp. lactis and Lc. lactis subsp. cremoris as starters and Lb. plantarum as adjunct culture could be a good approach to the development of functional sheep milk cheeses with reduced biogenic amine content.

As cheese ripening is a technological stage that involves the investment of a lot of money, the culture containing the four autochthonous LAB strains of the present study could be an alternative to reduce the ripening time of sheep milk cheeses and it also could 
produce high concentrations of bioactive compounds such as GABA and ornithine in cheese.

\section{ACKNOWLEDGMENTS}

The authors are grateful to the University of León (León, Spain) for granting a PhD fellowship to Erica Renes Bañuelos.

\section{REFERENCES}

Adeghate, E., Ponery, A.S., 2002. GABA in the endocrine pancreas: cellular localization and function in normal and diabetic rats. Tissue Cell 34, 1-6.

AOAC, 1990. Chloride (Total) in cheese Volhard method, in: Helrich, K. (Ed.), Official Methods of Analysis. Association of Official Analytical Chemists, Arlington, USA.

AOAC, 1980a. Hydrogen-ion activity $(\mathrm{pH})$, in: Horwitz, W. (Ed.), Official Methods of Analysis. Association of Official Analytical Chemists, Washington, DC, USA, p. 213.

AOAC, 1980b. Acidity in cheese, in: Horwitz, W. (Ed.), Official Methods of Analysis. Association of Official Analytical Chemists, Washington, DC, USA, p. 266.

Auty, M.A., Twomey, M., Guinee, T.P., Mulvihill, D.M., 2001. Development and application of confocal scanning laser microscopy methods for studying the distribution of fat and protein in selected dairy products. J. Dairy Res. 68, 417-27.

Azarnia, S., Robert, N., Lee, B., 2006. Biotechnological Methods to Accelerate Cheddar Cheese Ripening. Crit. Rev. Biotechnol. 26, 121-143.

Balthazar, C.F., Pimentel, T.C., Ferrão, L.L., Almada, C.N., Santillo, A., Albenzio, M., Mollakhalili, N., Mortazavian, A.M., Nascimento, J.S., Silva, M.C., Freitas, M.Q., Sant'Ana, A.S., Granato, D., Cruz, A.G., 2017. Sheep milk: physicochemical characteristics and relevance for functional food development. Compr. Rev. Food Sci. Food Saf. 16, 247-262.

Barrett, E., Ross, R.P., O’Toole, P.W., Fitzgerald, G.F., Stanton, C., 2012. ү-Aminobutyric acid production by culturable bacteria from the human intestine. J. Appl. Microbiol. $113,411-417$.

Broadley, K.J., 2010. The vascular effects of trace amines and amphetamines. Pharmacol. Ther. 125, 363-375.

Cotter, P.D., Hill, C., 2003. Surviving the acid test: responses of gram-positive bacteria to low pH. Microbiol. Mol. Biol. Rev. 67, 429-453.

Dhakal, R., Bajpai, V.K., Baek, K.H., 2012. Production of gaba (gamma-aminobutyric acid) by microorganisms: a review. Brazilian J. Microbiol. 43, 1230-1241.

Diana, M., Quílez, J., Rafecas, M., 2014a. Gamma-aminobutyric acid as a bioactive compound in foods: a review. J. Funct. Foods 10, 407-420.

Diana, M., Rafecas, M., Arco, C., Quilez, J., 2014b. Free amino acid profile of Spanish artisanal cheeses: Importance of gamma-aminobutyric acid (GABA) and ornithine content. J. Food Compos. Anal. 35, 94-100.

Diezhandino, I., Fernández, D., González, L., McSweeney, P.L.H., Fresno, J.M., 2015. Microbiological, physico-chemical and proteolytic changes in a Spanish blue cheese during ripening (Valdeón cheese). Food Chem. 168, 134-141. 
European Food Safety Authority (EFSA) Panel on Biological Hazards, 2011. Scientific opinion on risk based control of biogenic amine formation in fermented foods. EFSA J. 9, 1-93.

Everett, D.W., Auty, M.A.E., 2008. Cheese structure and current methods of analysis. Int. Dairy J. 18, 759-773.

Fernández, D., Arenas, R., Tornadijo, M.E., Ferrazza, R.E., Fresno, J.M., 2012. Zamorano cheese, in: Hui, Y.H., Evranuz, Ö.E. (Eds.), Handbook of animal-based fermented food and beverage technology. CRC Press, Boca Ratón, Florida, pp. 451-472.

FIL-IDF, 2008. Cheese-Determination of fat content-Van Gulik method. International Dairy Federation, Brussels, Belgium.

FIL-IDF, 2004. Cheese and processed cheese-Determination of the total solids content. International Dairy Federation, Brussels, Belgium.

FIL-IDF, 2001. Milk-Determination of nitrogen content-Part 1: Kjeldahl method. International Dairy Federation, Brussels, Belgium.

FIL-IDF, 1992. Milk and milk products. Preparation of test samples and dilutions for microbiological examination. International Dairy Federation, Brussels, Belgium.

Fox, P.F., Guinee, T.P., Cogan, T.M., McSweeney, P.L.H., 2016. Biochemistry of cheese ripening, in: Fundamentals of Cheese Science. Springer, New York, pp. 391-443.

González, L., Cuadrillero, A., Castro, J.M., Bernardo, A., Tornadijo, M.E., 2015. Selection of lactic acid bacteria isolated from San Simón da Costa Cheese (PDO) in order to develop an autochthonous starter culture. Adv. Microbiol. 5, 748-759.

Guinee, T.P., 2004. Salting and the role of salt in cheese. Int. J. Dairy Technol. 57, 99109.

Guinee, T.P., Fox, P.F., 2004. Salt in Cheese: Physical, chemical and biological aspects, in: Fox, P.F., McSweeney, P.L.H., Cogan, T.M., Guinee, T.P. (Eds.), Cheese: Chemistry, Physics and Microbiology. Elsiever Academic Press, London, pp. 207-259.

Hejtmánková, A., Pivec, V., Trnková, E., Dragounová, H., 2012. Differences in the composition of total and whey proteins in goat and ewe milk and their changes throughout the lactation period. Czech J. Anim. Sci. 57, 323-331.

Herreros, M.A., Fresno, J.M., González Prieto, M.J., Tornadijo, M.E., 2003. Technological characterization of lactic acid bacteria isolated from Armada cheese (a Spanish goats' milk cheese). Int. Dairy J. 13, 469-479.

Irsfeld, M., Spadafore, M., Prüß, B. M., 2013. $\beta$-phenylethylamine, a small molecule with a large impact. WebmedCentral, 4.

Kurata, K., Nagasawa, M., Tomonaga, S., Aoki, M., Akiduki, S., Morishita, K., Denbow, D.M., Furuse, M., 2012. Orally administered 1-ornithine reduces restraint stressinduced activation of the hypothalamic-pituitary-adrenal axis in mice. Neurosci. Lett. 506, 287-291.

Lacroix, N., St-Gelais, D., Champagne, C.P., Vuillemard, J.C., 2013. Gamma-aminobutyric acid-producing abilities of lactococcal strains isolated from old-style cheese starters. Dairy Sci. Technol. 93, 315-327.

Ladero, V., Calles-Enríquez, M., Fernández, M., Álvarez, M.A., 2010. Toxicological effects of dietary biogenic amines. Curr. Nutr. Food Sci. 6, 145-156.

Linares, D.M., del Rio, B., Redruello, B., Ladero, V., Martin, M.C., Fernandez, M., RuasMadiedo, P., Alvarez, M.A., 2016. Comparative analysis of the in vitro cytotoxicity of 
the dietary biogenic amines tyramine and histamine. Food Chem. 197, 658-663.

Linares, D.M., Martín, M., Ladero, V., Alvarez, M.A., Fernández, M., 2011. Biogenic Amines in Dairy Products. Crit. Rev. Food Sci. Nutr. 51, 691-703.

Madrau, M.A., Mangia, N.P., Murgia, M.A., Sanna, M.G., Garau, G., Leccis, L., Caredda, M., Deiana, P., 2006. Employment of autochthonous microflora in Pecorino Sardo cheese manufacturing and evolution of physicochemical parameters during ripening. Int. Dairy J. 16, 876-885.

Manca, G., Porcu, A., Ru, A., Salaris, M., Franco, M.A., De Santis, E.P.L., 2015. Comparison of $\gamma$-aminobutyric acid and biogenic amine content of different types of ewe's milk cheese produced in Sardinia, Italy. Ital. J. Food Saf. 4, 4700.

Mangia, N.P., Murgia, M.A., Garau, G., Sanna, M.G., Deiana, P., 2008. Influence of selected lab cultures on the evolution of free amino acids, free fatty acids and Fiore Sardo cheese microflora during the ripening. Food Microbiol. 25, 366-377.

Minervini, F., Bilancia, M.T., Siragusa, S., Gobbetti, M., Caponio, F., 2009. Fermented goats' milk produced with selected multiple starters as a potentially functional food. Food Microbiol. 26, 559-564.

Novella-Rodriguez, S., Veciana-Nogues, M.T., Izquierdo-Pulido, M., Vidal-Carou, M.C., 2003. Distribution of biogenic amines and polyamines in cheese. J. Food Sci. 68, 750-756.

O’Reilly, C.E., Kelly, A.L., Oliveira, J.C., Murphy, P.M., Auty, M.A.E., Beresford, T.P., 2003. Effect of varying high-pressure treatment conditions on acceleration of ripening of cheddar cheese. Innov. Food Sci. Emerg. Technol. 4, 277-284.

Piras, C., Cesare Marincola, F., Savorani, F., Engelsen, S.B., Cosentino, S., Viale, S., Pisano, M.B., 2013. A NMR metabolomics study of the ripening process of the Fiore Sardo cheese produced with autochthonous adjunct cultures. Food Chem. 141, 2137-2147.

Pouliot-Mathieu, K., Gardner-Fortier, C., Lemieux, S., St-Gelais, D., Champagne, C.P., Vuillemard, J.C., 2013. Effect of cheese containing gamma-aminobutyric acidproducing lactic acid bacteria on blood pressure in men. PharmaNutrition 1, 141148.

Poveda, J.M., Cabezas, L., McSweeney, P.L.H., 2004. Free amino acid content of Manchego cheese manufactured with different starter cultures and changes throughout ripening. Food Chem. 84, 213-218.

Poveda, J.M., Chicón, R., Cabezas, L., 2015. Biogenic amine content and proteolysis in Manchego cheese manufactured with Lactobacillus paracasei subsp. paracasei as adjunct and other autochthonous strains as starters. Int. Dairy J. 47, 94-101.

Poveda, J.M., Molina, G.M., Gómez-Alonso, S., 2016. Variability of biogenic amine and free amino acid concentrations in regionally produced goat milk cheeses. J. Food Compos. Anal. 51, 85-92.

Redruello, B., Ladero, V., Cuesta, I., Álvarez-Buylla, J.R., Martín, M.C., Fernández, M., Alvarez, M.A., 2013. A fast, reliable, ultra high performance liquid chromatography method for the simultaneous determination of amino acids, biogenic amines and ammonium ions in cheese, using diethyl ethoxymethylenemalonate as a derivatising agent. Food Chem. 139, 1029-1035.

Renes, E., Diezhandino, I., Fernández, D., Ferrazza, R.E., Tornadijo, M.E., Fresno, J.M., 
2014. Effect of autochthonous starter cultures on the biogenic amine content of ewe's milk cheese throughout ripening. Food Microbiol. 44, 271-277.

Salaün, F., Mietton, B., Gaucheron, F., 2005. Buffering capacity of dairy products. Int. Dairy J. 15, 95-109.

Schirone, M., Tofalo, R., Fasoli, G., Perpetuini, G., Corsetti, A., Manetta, A.C., Ciarrocchi, A., Suzzi, G., 2013. High content of biogenic amines in Pecorino cheeses. Food Microbiol. 34, 137-144.

Settanni, L., Moschetti, G., 2010. Non-starter lactic acid bacteria used to improve cheese quality and provide health benefits. Food Microbiol. 27, 691-697.

Siragusa, S., De Angelis, M., Di Cagno, R., Rizzello, C.G., Coda, R., Gobbetti, M., 2007. Synthesis of gamma-aminobutyric acid by lactic acid bacteria isolated from a variety of Italian cheeses. Appl. Environ. Microbiol. 73, 7283-90.

Sugino, T., Shirai, T., Kajimoto, Y., Kajimoto, O., 2008. 1-Ornithine supplementation attenuates physical fatigue in healthy volunteers by modulating lipid and amino acid metabolism. Nutr. Res. 28, 738-743.

ten Brink, B., Damink, C., Joosten, H.M.L.J., Huis in 't Veld, J.H.J., 1990. Occurrence and formation of biologically active amines in foods. Int. J. Food Microbiol. 11, 73-84.

Valsamaki, K., Michaelidou, A., Polychroniadou, A., 2000. Biogenic amine production in Feta cheese. Food Chem. 71, 259-266. 


\section{DISCUSIÓN GENERAL}





\section{DISCUSIÓN GENERAL}

En la actualidad la creciente demanda de alimentos con efectos beneficiosos sobre la salud humana incentiva a la industria alimentaria a desarrollar nuevos alimentos que satisfagan las exigencias del consumidor.

En este sentido, el queso, el cual supone un porcentaje importante del comercio agrícola mundial, ha suscitado en los últimos años una connotación negativa por parte del consumidor debido a la relación del contenido en ácidos grasos saturados de este alimento y el desarrollo de algunas enfermedades. Sin embargo, el queso también presenta compuestos que pueden mejorar la salud del consumidor, como es el caso del CLA. Hay que tener en cuenta que la mayor cantidad de este compuesto bioactivo aportada a la dieta proviene de la leche y de los productos lácteos, habiéndose observado que la grasa de la leche de oveja presenta una mayor concentración de CLA que la de vaca o la de cabra.

Ante la situación planteada, la presente Tesis muestra distintas aproximaciones de mejora del perfil nutricional del queso de oveja. Con este propósito, se estudiaron aspectos que van desde la producción animal hasta la tecnología de elaboración del queso.

En este trabajo de investigación, fue identificada leche de oveja de tanque con un perfil en ácidos grasos más saludable a través del estudio del sistema de manejo practicado en granjas de ovino. Igualmente, se ha demostrado la importancia, incluyendo las posibles limitaciones y futuras líneas de investigación, que juega el diseño de cultivos de bacterias lácticas seleccionadas por su capacidad para sintetizar CLA con vistas a su aplicación en la elaboración de quesos de oveja con un perfil nutricional mejorado. Otro factor estudiado ha sido el tiempo de maduración de los quesos, el cual en conjunción con los cultivos empleados ejerce una influencia muy importante en la concentración de compuestos aminoacídicos con efectos beneficiosos sobre la salud humana, como el GABA y la ornitina, y en la concentración de aminas biógenas presentes en el producto final. A lo largo de la elaboración de los quesos también se controló la evolución de los parámetros físico-químicos y de los principales grupos microbianos para garantizar un control del proceso tecnológico en todos los lotes de queso elaborados. Finalmente, se llevó a cabo un análisis sensorial de los quesos porque tal y como ha sido mencionado anteriormente, no sólo es necesario mejorar la calidad nutricional de un alimento sino que también ha de tener unas adecuadas características organolépticas para su aceptación por parte del consumidor. A continuación, los resultados de esta Tesis son discutidos en base a los objetivos específicos establecidos.

\subsection{Estudio del perfil en ácidos grasos de leche de tanque procedente de granjas de ovino comerciales}

En el capítulo 1 de la presente Tesis se recogen los resultados que a continuación son discutidos.

$\mathrm{El}$ efecto de diversos factores asociados al sistema de manejo de los rumiantes sobre el perfil de ácidos grasos de la leche ha sido estudiado ampliamente en rebaños experimentales (Cabiddu et al., 2005; Hervás et al., 2008; Kalač y Samková, 2010; Stanton et al., 2003; Tsiplakou et al., 2008, 2006). 
Sin embargo, hay poca información disponible sobre el efecto de la alimentación, de la etapa de lactación, del mes de muestreo y del rebaño en el perfil de ácidos grasos de la leche procedente de granjas de ovino comerciales. En consecuencia, los resultados obtenidos en este estudio proporcionan a la industria láctea nuevos conocimientos sobre las prácticas de manejo habituales en granjas de ovino que podrian conducir a una mejora en la calidad nutricional de la leche de oveja.

En esta Tesis, con el fin de identificar leche de oveja de tanque con alto contenido en CLA y con un perfil en ácidos grasos más saludable, se analizó leche de tanque procedente de 30 granjas comerciales durante los meses de abril, mayo, junio y julio. Un aspecto importante a resaltar es que las granjas de ovino objeto de este estudio fueron seleccionadas y agrupadas en función del régimen de alimentación practicado: en el primer grupo (G1) la alimentación consistió en $50 \%$ de pastoreo más ensilado de alfalfa y granos de cebada, en el segundo grupo (G2) la alimentación se basaba en $25 \%$ de pastoreo más ensilado de alfalfa y heno y en el tercer grupo (G3) consistió en $0 \%$ de pastoreo con alimentación a base de ensilado de alfalfa, heno y un concentrado comercial.

En relación con los ácidos grasos con efectos beneficiosos en la salud humana o sus precursores, cabe destacar que la leche de tanque procedente del G1 presentó la menor proporción de ácido linoleico; sin embargo, mostró la mayor proporción de CLA con respecto a las proporciones de estos mismos ácidos grasos observadas en la leche de tanque procedente de los otros dos grupos estudiados. Este hecho pudo ser parcialmente explicado por la variación observada en la actividad de la $\Delta-9$ desaturasa (en la glándula mamaria) entre los diferentes grupos a través de la relación ácido miristoleico/ácido mirístico. En este contexto, es importante explicar que la enzima $\Delta-9$ desaturasa añade un doble enlace en la posición 9 y la configuración cis a ácidos grasos insaturados con una longitud de cadena entre 10 y 18 átomos de carbono y se ha observado que la relación ácido miristoleico/ácido mirístico es la forma más fiable para determinar la actividad de esta enzima. Esto se debe principalmente a que el ácido miristoleico presente en la leche se genera casi exclusivamente (más del 95\%) mediante síntesis endógena a partir del ácido mirístico, a diferencia de los otros ácidos grasos monoinsaturados, los cuales también pueden proceder de la dieta (Griinari et al., 2000; Renna et al., 2012). En el presente estudio, el G1 presentó un valor mayor para esta relación que el G2 y el G3, lo que significa que la actividad de la $\Delta-9$ desaturasa fue mayor en el G1 y de ahí que previamente en este grupo se observase una menor proporción de ácido linoleico pero una mayor proporción de CLA en relación con los otros dos grupos estudiados. Estos resultados fueron similares a los descritos por Lock y Garnsworthy (2003), quienes señalaron que las vacas alimentadas bajo sistema de pastoreo mostraron un aumento en la actividad de la $\Delta$ 9 desaturasa en la glándula mamaria. Así mismo, esta misma tendencia en la actividad de la $\Delta$-9 desaturasa fue descrita por Renna et al. (2012) en su estudio del perfil de ácidos grasos en leche de cabra. En lo que respecta a la proporción de CLA observada por estos autores y por Couvreur et al. (2006) en leche de vaca, ésta fue mayor que la observada en nuestro estudio, pudiendo ser debido a las diferencias existentes en la composición botánica de los pastos frescos, así como también porque los rebaños estudiados en el presente trabajo fueron comerciales y no experimentales.

Adicionalmente, la leche procedente del G1 presentó una menor relación omega6/omega-3 que la leche procedente de los otros dos grupos, lo cual podría ser explicado 
por una mayor ingesta de ácido a-linolénico a partir del pasto fresco. No obstante, los cambios descritos en el perfil de ácidos grasos de la leche no sólo se deben al suministro de pasto en la dieta sino que también pueden estar asociados a los forrajes y concentrados incluidos en la dieta de las ovejas. En este sentido, el G3 presentó las proporciones más bajas de CLA y ácido a-linolénico con respecto a los otros dos grupos estudiados. Este hecho pudo ser debido a que fue el único grupo constituido por granjas en las que la alimentación de las ovejas consistió exclusivamente en forraje y concentrado. Según lo descrito por Chillard et al. (2007), este tipo de dieta no contribuye a incrementar la proporción de CLA en la leche, debido a que esta no aporta cantidades suficientes de precursores. En el presente estudio, el G1 estuvo constituido por granjas en las que las ovejas fueron alimentadas con una proporción de forraje menor que las ovejas pertenecientes al G2; sin embargo, las ovejas del G1 pastaron más que las del G2, lo que se tradujo en una mayor proporción de CLA en la leche procedente del G1. Es preciso indicar que cuanto más pastan las ovejas, la microbiota del rumen puede verse afectada, favoreciendo que la biohidrogenación sea incompleta. Este hecho conduce a una mayor sintesis de ácido vacénico, el cual puede ser desaturado en la glándula mamaria por acción de la enzima $\Delta-9$ desaturasa dando lugar una mayor proporción de CLA en la leche (Tsiplakou et al., 2006). De todo esto se deduce que, los factores que pueden afectar a la proporción de este ácido graso beneficioso en la leche de oveja podrian ser: la ingesta de precursores en la dieta y el grado de biohidrogenación que tiene lugar en el rumen.

Las etapas de lactación consideradas en el presente estudio fueron: 20-60 días posparto (inicial), 60-110 días posparto (media) y 110-160 días postparto (final). Este factor explicó menos del 4,18\% de la varianza para los ácidos grasos estudiados y no afectó a la proporción de CLA presente en la leche de oveja. Por esta razón, el efecto de la etapa de lactación sobre la proporción de ácidos grasos presentes en la leche de oveja fue menos importante que el del resto de los factores estudiados.

Con respecto al mes de muestreo, la mayor proporción de CLA se observó en el mes de abril seguido de mayo, junio y julio. Estos resultados fueron consistentes con los con los descritos por Tsiplakou et al. (2006), quienes observaron que los valores más altos de CLA en leche de oveja se detectan en abril y mayo, mientras que la proporción de este ácido graso es más baja en enero, marzo y junio. Como en nuestro estudio, estos autores detectaron niveles más altos de CLA en primavera, cuando el forraje es rico en ácido alinolénico (Tsiplakou et al., 2008). Se ha descrito que la proporción de este ácido graso disminuye a medida que el forraje madura y presenta una mayor proporción de fibra (Dewhurst et al., 2001). En consecuencia, la ingesta de forraje deficiente en ácido alinolénico conduce a una disminución en la concentración de ácido vacénico, el cual es un intermediario generado durante la biohidrogenación en el rumen. Este hecho a su vez da lugar a una reducción en el CLA sintetizado a partir de ácido vacénico en la glándula mamaria (Nudda et al., 2005), lo que contribuirá a que la concentración de este ácido graso bioactivo presente en la leche sea menor.

Hay que señalar que la interacción entre el mes de muestro y el régimen de alimentación fue significativa $(P \leq 0,01)$ para el CLA y para la relación CLA/ácido linoleico. En abril, la leche procedente del G1 y del G2 mostró mayores valores de CLA y de la relación CLA/ácido linoleico que la leche recogida de los mismos grupos en julio. Sin embargo, no se observaron diferencias significativas $(P>0,05)$ entre los valores del CLA y 
en la relación CLA/ácido linoleico de la leche del G3 recogida entre abril y julio. Es decir, el mes de muestreo solo influirá significativamente en la proporción de CLA en la leche cuando la alimentación esté basada en el pastoreo.

Por último, en el análisis estadístico mediante agrupación jerárquica utilizando el método Ward de la proporción de ácidos grasos presentes en la leche procedente de los rebaños estudiados se formaron dos clusters, reflejando las diferencias existentes entre los distintos rebaños. El primer cluster estuvo formado por los rebaños pertenecientes al G3 y por algún rebaño del G2, mientras que el segundo cluster estuvo constituido por el resto de los rebaños del G2 y los rebaños del G1. Este último cluster mostró una mayor proporción media de CLA que el cluster 1 . Así mismo, el cluster 2 presentó los valores medios más bajos para la relación omega-6/omega-3 e índice de aterogenicidad en comparación con el cluster 1. En consecuencia, estos resultados fueron similares a los observados previamente cuando se analizó el efecto del régimen de alimentación.

\subsection{Estudio de la capacidad de cepas de bacterias ácido lácticas para producir CLA}

La calidad nutricional de los productos lácteos, en particular del queso de oveja, no sólo puede ser incrementada mediante el empleo de leche con un perfil en ácidos grasos más saludable a través del control del sistema de manejo de los rumiantes sino que también puede ser mejorada mediante el uso de bacterias ácido lácticas con capacidad para convertir el ácido linoleico presente en la leche en CLA por acción de la enzima linoleato isomerasa. Por este motivo, en la presente Tesis se seleccionaron cepas de bacterias ácido lácticas, procedentes de la colección del Departamento de Higiene y Tecnología de los Alimentos de la Universidad de León, con capacidad para sintetizar CLA a partir del ácido linoleico como sustrato. Ante la necesidad de la industria quesera para mantener la singularidad de cada variedad de queso así como para desarrollar quesos con características sensoriales atractivas para el consumidor, las cepas estudiadas en el presente trabajo fueron aisladas de quesos artesanales y seleccionadas en base a la buena aptitud tecnológica que presentaron en estudios previos (González et al., 2015, 2010, 2007; Herreros et al., 2003) con el fin de utilizarlas en el diseño de cultivos iniciadores y adjuntos.

En los capítulos 2 y 3 de la presente Tesis se recogen los principales resultados relacionados con el estudio de la capacidad de producción de CLA por parte de las bacterias ácido lácticas y cuya discusión detallada se presenta a continuación.

En primer lugar, se comprobó la tolerancia al ácido linoleico de las cepas seleccionadas debido a que en varios estudios se ha demostrado que este ácido graso poliinsaturado puede retardar o inhibir el crecimiento de algunas bacterias (Gorissen et al., 2010; Jiang et al., 1998; Nieuwenhove et al., 2007a). La concentración de ácido linoleico utilizada en este estudio se basó en la concentración media $(0,5 \mathrm{mg} / \mathrm{mL})$ presente en leche de oveja (De La Fuente et al., 2009), lo que significa que las cepas que fuesen identificadas como productoras de CLA serían capaces de crecer en la leche de oveja empleada como materia prima en la elaboración de los lotes de queso.

De las 85 cepas estudiadas, solo 6 cepas pertenecientes a las especies Leuconostoc pseudomesenteroides, Leuconostoc mesenteroides y Enterococcus faecalis mostraron 
inhibición en su crecimiento y 1 cepa de Lactococcus lactis subsp. lactis no creció tras $48 \mathrm{~h}$ de incubación. Estos resultados confirmaron que la inhibición del crecimiento de las bacterias ácido lácticas por acción del ácido linoleico es dependiente de la cepa y no de la especie, tal y como fue observado también por Gorissen et al. (2010) en cepas de Bifidobacterium.

Generalmente, la identificación de cepas productoras de CLA se lleva a cabo mediante análisis cromatográfico. Ahora bien, El-Salam et al. (2010) han señalado que aunque este método proporciona buenos resultados, también implica una inversión económica y de tiempo elevada. Por este motivo, se decidió utilizar el método basado en la determinación espectrofotométrica de los dobles enlaces conjugados presentes en los ácidos grasos. Este método constituye una buena alternativa al análisis cromatográfico, ya que proporciona ventajas a la hora de analizar un amplio número de muestras, como el que se presenta en este trabajo, al implicar un menor tiempo de trabajo y el equipamiento necesario para llevarlo a cabo es más económico (Barrett et al., 2007).

Las cepas analizadas en esta Tesis (85 cepas) pertenecieron a diferentes géneros: Lactococcus, Leuconostoc, Lactobacillus y Enterococcus. Únicamente fueron capaces de sintetizar CLA en medio de cultivo suplementado con ácido linoleico, 2 cepas de Lactobacillus casei subsp. casei (SS 1614 y SS 1644) y 4 cepas de Lactobacillus plantarum (TAUL 1539, TAUL 1588, TAUL 1795 y TAUL 1522). Los Lactobacillus son bacterias ácido lácticas, non-starters, los cuales juegan un papel relevante en la maduración de los quesos, por lo que su estudio como posibles cultivos adjuntos es de especial interés.

Diversos autores han señalado que la concentración de CLA producida por las bacterias ácido lácticas puede verse afectada por diversos factores como es el tiempo de incubación y el pH (El-Salam et al., 2010; Rodríguez-Alcalá et al., 2011). En este sentido y en relación con el tiempo de incubación, todas las cepas estudiadas produjeron un incremento estadísticamente significativo $(P \leq 0,001)$ de la concentración de CLA entre las $24 \mathrm{~h}$ y $48 \mathrm{~h}$ de incubación. En consecuencia, el tiempo de incubación es un factor importante a tener en cuenta en la producción de CLA por parte de las cepas de Lactobacillus. De igual manera, se observó que Lactobacillus plantarum TAUL 1588 resultó ser la cepa que produjo la mayor concentración de CLA tras 24 y 48 horas de incubación alcanzando valores similares a los observados por Rodríguez-Alcalá et al. (2011) para la cepa Lactobacillus plantarum-2, empleando el mismo método y por Terán et al. (2015) para Lactobacillus plantarum CRL1935 mediante cromatografia de gases. Debido a su capacidad para sintetizar altas concentraciones de CLA, Lactobacillus plantarum TAUL 1588 es una cepa de gran interés para investigar su papel como cultivo adjunto en el desarrollo de productos lácteos funcionales.

En lo que respecta a las cepas autóctonas de Lactobacillus casei estudiadas; Lactobacillus casei subsp. casei SS 1644 fue la cepa que produjo la menor concentración de CLA a las $24 \mathrm{~h}$ de incubación, mientras que Lactobacillus casei subsp. casei SS 1614 produjo la menor concentración de CLA a las 48 h. En general, las cepas de Lactobacillus casei subsp. casei fueron menos eficientes en la síntesis de CLA que las cepas de Lactobacillus plantarum. Simultáneamente se observó que las cepas que produjeron un mayor descenso en el pH del medio tras 24 y 48 horas de incubación, Lactobacillus plantarum TAUL 1539 y TAUL 1588, fueron también las más productoras de CLA durante estos tiempos de incubación. 
Hay que tener en cuenta que la linoleato isomerasa es la enzima responsable de la producción de CLA a partir del ácido linoleico como sustrato en las bacterias ácido lácticas (Chen, 2012; Gorissen et al., 2011). En este estudio, se identificó la presencia del gen que codifica la linoleato isomerasa en las seis cepas detectadas como productoras de CLA. En el caso de las cepas de Lactobacillus plantarum, el tamaño aproximado de la banda detectada fue de 500 pares de bases, mientras que para las dos cepas de Lactobacillus casei subp. casei fue de 600 pares de bases. Este gen también fue detectado en alguna de las cepas que no produjeron CLA. Este hecho ha sido descrito previamente por Gorissen et al. (2011), los cuales observaron que la enzima linoleato isomerasa puede estar presente en las cepas pero, la expresión de la misma podría verse afectada por diversos factores tales como el $\mathrm{pH}$ o la temperatura, y estos efectos a su vez son dependientes de la cepa.

Otro aspecto muy importante que hay que resaltar es que aunque los métodos espectrofotométrico y genético empleados son útiles a la hora de identificar cepas de bacterias ácido lácticas productoras de CLA, dichos métodos no permiten detectar los distintos isómeros del CLA producidos (Barrett et al., 2007). La identificación y cuantificación de los isómeros CLA sintetizados por parte de las bacterias ácido lácticas puede ser de gran interés debido a que las propiedades beneficiosas para la salud humana están relacionadas principalmente con dos de ellos: cis-9,trans-11 $\mathrm{C}_{18: 2}$ y trans-10,cis-12 $\mathrm{C}_{18: 2}$. No obstante, desde hace varios años, el isómero trans-9, trans-11 $\mathrm{C}_{18: 2}$ también se encuentra bajo investigación debido a sus potenciales efectos anticarcinogénicos observados en líneas celulares de cáncer de colon humano (Coakley et al., 2006) y por su capacidad para inducir la expresión de genes implicados en el metabolismo lipídico (Ecker et al., 2009). Por esta razón, se realizó un estudio más específico, utilizando cromatografia de gases, que evaluara la capacidad para sintetizar CLA por estas seis cepas autóctonas de Lactobacillus en medio de cultivo y en leche desnatada suplementados con ácido linoleico bajo diferentes tiempos de incubación (24, 48 y $72 \mathrm{~h})$.

Los resultados observados en este estudio mostraron que el tiempo óptimo de incubación para la producción de CLA por parte de las cepas estudiadas en medio de cultivo o en leche desnatada fue $48 \mathrm{~h}$. En este sentido, Nieuwenhove et al. (2007b) han descrito la existencia de una relación entre la fase de crecimiento de las bacterias y la concentración de CLA sintetizada en el medio de cultivo. En consecuencia, la mayor concentración de CLA observada a las 48 h de incubación pudo estar relacionada con el incremento en el recuento de células viables tras 48 h en comparación con los recuentos observados a las $24 \mathrm{~h}$ de incubación.

Adicionalmente se observó que los niveles de CLA total en medio de cultivo disminuyeron significativamente $(P<0,05)$ a partir de $48 \mathrm{~h}$ de incubación. Este hecho pudo ser debido al desarrollo de reacciones de oxidación, así como al metabolismo oxidativo de las cepas durante el tiempo de incubación, lo que favorecería el catabolismo de este compuesto (Ogawa et al., 2001; Rodríguez-Alcalá et al., 2011; Wang et al., 2007).

El tipo de medio de crecimiento (medio de cultivo o leche desnatada) influyó en la producción de CLA por parte de las bacterias ácido lácticas estudiadas. En este contexto, la capacidad de las cepas de Lactobacillus plantarum para sintetizar CLA se redujo significativamente cuando se incubaron en leche desnatada. Contrariamente, en el caso de las cepas de Lactobacillus casei subsp. casei, la producción de CLA fue más eficiente en leche desnatada, alcanzando valores de CLA total a las 48 horas de incubación similares a 
los producidos por las cepas de Lactobacillus plantarum TAUL 1588 en medio de cultivo durante el mismo periodo de tiempo. Cabe resaltar que tras 24 horas de incubación en leche desnatada, Lactobacillus plantarum TAUL 1588, TAUL 1795 y TAUL 1522 fueron incapaces de sintetizar CLA y Lactobacillus plantarum TAUL 1539 sólo sintetizó 1,43 $\mu \mathrm{g} / \mathrm{mL}$ de CLA total. Por el contrario, Lactobacillus casei subsp. casei SS 1614 and SS 1644 produjeron 27,16 y $26,52 \mu \mathrm{g} / \mathrm{mL}$ de CLA total, respectivamente. La explicación de estos resultados aún no está clara ya que los mecanismos de síntesis de CLA por parte de las bacterias ácido lácticas son inciertos. Ahora bien, este hecho quizás pudo ser debido a que como Gorissen et al. (2011) han indicado, la actividad de la linoleato isomerasa puede verse afectada por diversos factores ambientales, como el $\mathrm{pH}$.

El análisis mediante cromatografia de gases llevado a cabo en este estudio mostró que bajo las condiciones experimentales, las seis cepas de Lactobacillus produjeron tres isómeros CLA: cis-9,trans-11 $\mathrm{C}_{18: 2}$, trans-10,cis-12 $\mathrm{C}_{18: 2}$ y trans-9,trans-11 $\mathrm{C}_{18: 2}$, excepto cuando fueron incubadas en leche desnatada, las cuales sólo fueron capaces de sintetizar dos isómeros CLA: cis-9,trans-11 $\mathrm{C}_{18: 2}$ y trans-9,trans-11 $\mathrm{C}_{18: 2}$. En definitiva, el tipo de medio empleado afectó a la producción de los diferentes isómeros del CLA sintetizados por las bacterias ácido lácticas.

En relación con este último aspecto, se observó claramente que la mayor concentración de los isómero cis-9,trans-11 $\mathrm{C}_{18: 2}$, trans-10,cis-12 $\mathrm{C}_{18: 2}$ y trans-9,trans-11 $\mathrm{C}_{18: 2}$ en medio de cultivo suplementado con ácido linoleico tras $48 \mathrm{~h}$ fue producida por la cepa de Lactobacillus plantarum TAUL 1588. En cambio, tras ese mismo periodo de incubación pero utilizando leche desnatada suplementada con ácido linoleico, la cepa que produjo la mayor concentración de los isómeros cis-9, trans-11 $\mathrm{C}_{18: 2}$ y trans-9, trans-11 $\mathrm{C}_{18: 2}$ fue Lactobacillus casei subsp. casei SS 1644. Comparativamente, aunque las 6 cepas estudiadas fueron capaces de sintetizar CLA a partir del ácido linoleico como sustrato, se encontraron diferencias significativas $(P \leq 0,05)$ en la concentración de los diferentes isómeros CLA sintetizados por cepas de la misma especie, lo que significó que la capacidad para producir este compuesto fue dependiente de cepa y no de la especie.

En cuanto al tiempo de incubación, este afectó a la proporción de isómeros CLA sintetizados por las cepas de Lactobacillus estudiadas, siguiendo un patrón común. En medio de cultivo, tras 24 y 48 h de incubación, el isómero mayoritario detectado fue el cis9,trans-1 $1 \mathrm{C}_{18: 2}$, mientras que tras $72 \mathrm{~h}$ de incubación fue el trans-9,trans-11 $\mathrm{C}_{18: 2}$. Estos resultados fueron similares a los descritos por otros autores (Ando et al., 2004), quienes señalaron que conforme transcurre el tiempo de incubación, la concentración del isómero trans-9,trans-1 $1 \mathrm{C}_{18: 2}$ tiende a incrementarse con respecto a la concentración del isómero cis-9,trans-1 $1 \mathrm{C}_{18: 2}$. Sin embargo, cuando el medio de crecimiento fue leche desnatada, el trans-9,trans-1 $1 \mathrm{C}_{18: 2}$ fue el principal isómero detectado a lo largo de los distintos tiempos de incubación.

Llegados a este punto, conviene indicar que actualmente los mecanismos de producción e interconversión entre los isómeros CLA no están claros y requieren más estudios.

Tal y como ha sido mencionado con anterioridad, los Lactobacillus son bacterias ácido lácticas consideradas como non-starters, las cuales constituyen la microbiota predominante de los quesos durante la maduración de los mismos. Los Lactobacillus toleran bien los ambientes hostiles e influyen fuertemente en la bioquímica que tiene lugar 
durante la maduración de la cuajada, contribuyendo al desarrollo de las características finales del queso (Settanni and Moschetti, 2010). En relación con las concentraciones de CLA producidas por las cepas Lactobacillus plantarum TAUL 1588 y Lactobacillus casei subsp. casei SS 1644 a las 48 h de incubación en medio de cultivo y en leche desnatada suplementados con $0,5 \mathrm{mg} / \mathrm{mL}$ de ácido linoleico, estas fueron comparables con los resultados observados en cepas de las mismas especies (Adeghate and Ponery, 2002; Gorissen et al., 2010; Terán et al., 2015). En consecuencia, el estudio de estas cepas como potenciales cultivos adjuntos es de especial interés, ya que estos hallazgos sugieren que podrían ser empleados para el desarrollo de productos lácteos funcionales fermentados con niveles elevados de CLA.

\subsection{Estudio de la capacidad de cepas de bacterias ácido lácticas para producir GABA}

En los últimos años, el GABA ha suscitado un gran interés ya que ejerce numerosas funciones fisiológicas: neurotransmisor, regulador de la tensión arterial y secretagogo de insulina (Adeghate y Ponery, 2002; Diana et al., 2014a; Okada et al., 2000). El GABA es sintetizado por la glutamato descarboxilasa, una enzima dependiente del piridoxal 5'fosfato, la cual cataliza la a-descarboxilación del L-glutamato o sus sales a GABA (Narayan and Nair, 1990). Es importante resaltar que esta enzima ha sido detectada en bacterias ácido lácticas (Cotter y Hill, 2003; Komatsuzi et al., 2008) y en consecuencia, el estudio de la capacidad productora de GABA por cepas de bacterias ácido lácticas tiene interés con vistas a su utilización como cultivos iniciadores o adjuntos en la elaboración de productos lácteos. En este sentido, tal y como Siragusa et al. (2007) han señalado, el queso es un buen vehículo de GABA porque las caseinas de la leche presentan una alta proporción de L-glutamato, el cual es liberado durante la maduración de los quesos y puede ser metabolizado a GABA por acción de las bacterias ácido lácticas (Hejtmánková et al., 2012).

Por estas razones, las 85 cepas de bacterias ácido lácticas mencionadas en el apartado anterior también fueron objeto de estudio con el fin de detectar aquéllas con capacidad para sintetizar GABA a partir del glutamato monosódico como sustrato en medio de cultivo (Elliker o MRS). Los resultados obtenidos en este estudio y que son discutidos a continuación, se recogen en el capítulo 2 de la presente Tesis.

Diez de las 85 cepas estudiadas fueron identificadas como productoras de GABA: Lactococcus lactis subp. lactis (GE 61, GE 118, GE 102, GE 103) y Lactobacillus brevis (TAUL 141, TAUL 174, TAUL 69, TAUL 70, TAUL 179, TAUL 195). Estos resultados mostraron la variabilidad existente entre cepas de la misma especie y permitieron confirmar que la capacidad para sintetizar GABA es dependiente de la cepa, tal y como fue descrito por Siragusa et al. (2007).

Así mismo, se estudió el efecto del tiempo de incubación sobre la producción de GABA por parte de las 10 cepas identificadas como productoras ya que como han señalado Dahakal et al. (2012), diferentes factores implicados en el proceso de fermentación, entre ellos el tiempo de incubación, pueden afectar a la síntesis de GABA por parte de los microorganismos. En relación con la evolución de la producción de GABA por parte de las cepas de bacterias ácido lácticas estudiadas a lo largo de los distintos tiempos de incubación en el medio de cultivo suplementado con glutamato monosódico, se observó 
que todas las cepas mostraron un incremento estadísticamente significativo $(P \leq 0,05)$ en la sintesis de GABA de 24 a 72 horas de incubación. Estos resultados fueron similares a los descritos por Wu y Sha (2015), quienes detectaron un incremento en la producción de GABA por parte de 9 bacterias ácido lácticas tras 72 horas de incubación en medio de cultivo MRS suplementado con $50 \mathrm{mg} / \mathrm{mL}$ de glutamato monosódico como sustrato.

Uno de los resultados más importantes de nuestro estudio fue que la cepa que produjo la mayor concentración de GABA $(2524,05 \mu \mathrm{g} / \mathrm{mL})$ fue Lactobacillus brevis TAUL 195 tras 72 horas de incubación, lo que la convierte en una cepa autóctona con gran interés para ser utilizada como cultivo adjunto en la elaboración de productos lácteos.

Los resultados observados en el presente estudio mostraron que las cepas de Lactobacillus brevis fueron más eficientes que las cepas de Lactococcus lactis en la producción de GABA, coincidiendo con lo descrito por otros autores (Barrett et al., 2012; Wu y Shah, 2017; Zhang et al., 2012).

Cabe señalar que Diana et al. (2014a) han indicado que el empleo de cultivos compuestos por varias cepas productoras de GABA puede constituir una estrategia nueva y eficiente para incrementar la concentración de GABA en los productos lácteos. Así mismo, Settani y Moschetti (2010) han descrito que la combinación de cepas de Lactococcus lactis y de cepas de Lactobacillus puede mejorar las características sensoriales del queso. En base a estas consideraciones, sería interesante llevar a cabo más estudios para diseñar cultivos con las cepas detectadas como productoras de GABA en este estudio, pertenecientes a las especies Lactococcus lactis y Lactobacillus brevis, ya que no sólo nos permitirian obtener quesos con buenas características sensoriales sino que también con un elevado contenido en GABA, el cual se ha observado que tiene efectos beneficiosos sobre la salud humana.

Es importante indicar que el sistema glutamato descarboxilasa, el cual está formado por la enzima glutamato descarboxilasa y por el antiporter glutamato-GABA, es el responsable de la producción de GABA por parte de las bacterias ácido lácticas. Por este motivo, en este estudio, se comprobó la presencia de los genes que codifican la enzima glutamato descarboxilasa y el antiporter glutamato-GABA en las cepas detectadas como productoras de GABA y en algunas de las no productoras.

En este contexto, Nomura et al. (1999) han observado que las cepas de Lactococcus lactis sólo presentan un gen que codifica la enzima glutamato descarboxilasa mientras que $\mathrm{Li}$ et al. (2013) han identificado dos genes que codifican esta enzima en cepas de Lactobacillus brevis. Ambos hechos fueron observados también en el presente estudio.

En el caso de las cepas pertenecientes a la especie Lactobacillus brevis, se detectó la presencia de los genes que codifican la enzima glutamato decarboxilasa y el antiporter glutamato-GABA en las cepas identificadas como productoras de GABA y también en alguna de las cepas no productoras. Tal y como Siragusa et al. (2007) han indicado, este hecho pudo ser debido a que la expresión de estos genes puede verse afectada por diversos factores como por ejemplo el $\mathrm{pH}$ del medio.

No obstante, cuando las cepas estudiadas pertenecieron a la especie Lactococcus lactis sólo se detectó la presencia de estos genes en las cuatro cepas identificadas previamente como productoras de GABA. Estos resultados abren la posibilidad de utilizar esta técnica como método para identificar cepas de Lactococcus lactis productoras de 
GABA en base a la presencia de estos genes. Sin embargo, esto debería ser estudiado en un mayor número de cepas.

\subsection{Diseño de co-cultivos constituidos por cepas de bacterias ácido lácticas con capacidad para sintetizar CLA}

Otro de los aspectos estudiados en esta Tesis fue la posibilidad de diseñar cultivos que pudieran incrementar el contenido en CLA en el queso de oveja, debido a la buena capacidad para sintetizar este compuesto que presentaron las 6 cepas de Lactobacillus. Los resultados que son discutidos a continuación aparecen recogidos en el capítulo 3 de la presente Tesis.

En base a que los cultivos iniciadores comerciales incluyen cepas de Lactococcus lactis como microorganismos acidificantes, en este estudio se diseñaron 4 cultivos constituidos por cepas de esta especie combinadas con dos de las cepas de Lactobacillus (TAUL 1588 y SS 1644) identificadas como productoras de CLA (Figura 4). Dos de estos cultivos (1 y 3) incluyeron cepas de Lactococcus lactis subsp. lactis y Lactococcus lactis subsp. cremoris de origen comercial (CHOOZIT ${ }^{\mathrm{TM}}$ LYO MA 011) y los otros dos (2 y 4) estuvieron constituidos por las cepas autóctonas Lactococcus lactis subsp. lactis TAUL 238 y Lactococcus lactis subsp. cremoris TAUL 1239. Es necesario indicar que ninguna cepa de Lactococcus lactis incluida en este estudio fue capaz de sintetizar CLA. Estas cepas de Lactococcus se seleccionaron para el diseño de los cultivos porque en estudios previos mostraron una buena aptitud tecnológica (Herreros et al., 2003) y en el test de compatibilidad, realizado siguiendo el método descrito por Schillinger y Lücke (1989), fueron las cepas que presentaron el mejor comportamiento entre ellas y con las cepas de Lactobacillus productoras de CLA.

El objetivo de este planteamiento fue establecer si el empleo de cepas de Lactococcus lactis comerciales o autóctonas podría afectar a la síntesis de CLA por parte de las cepas de Lactobacillus productoras de este compuesto. El criterio seguido para la selección de las cepas de Lactobacillus se basó en que la cepa de Lactobacillus plantarum TAUL 1588 fue la cepa que produjo la mayor concentración de CLA en medio de cultivo y que la cepa de Lactobacillus casei subsp. casei SS 1644 fue la que sintetizó mayor concentración de este ácido graso biactivo en leche desnatada. A su vez, estas cepas presentaron una buena compatibilidad entre ellas. A continuación, en el caso de los cultivos 3 y 4 se pretendía estudiar si la combinación de las dos cepas productoras de CLA podría aumentar la producción de este compuesto más que ellas mismas por separado (cultivos 1 y 2) (Figura 4).

En base a los planteamientos descritos, se estudió la capacidad para sintetizar CLA por parte de estos cuatro cultivos en medio de cultivo y en leche desnatada suplementados con ácido linoleico durante tres tiempos de incubación (24, 48 y 72 h).

En relación con los isómeros CLA sintetizados por los diferentes cultivos a lo largo de la incubación, cuando se utilizó el medio de cultivo para el crecimiento, fue observado que el contenido en el isómero cis-9,trans-11 $\mathrm{C}_{18: 2}$ presentó diferencias estadísticamente significativas $(P \leq 0,05)$ entre los cultivos a las 24,48 y $72 \mathrm{~h}$ de incubación. En todos los casos, la mayor concentración de este isómero se produjo a las 48 h y los cultivos que 
mostraron una mayor producción de este isómero fueron el 1 y el 2, no encontrándose diferencias estadísticamente significativas $(P>0,05)$ entre ellos.

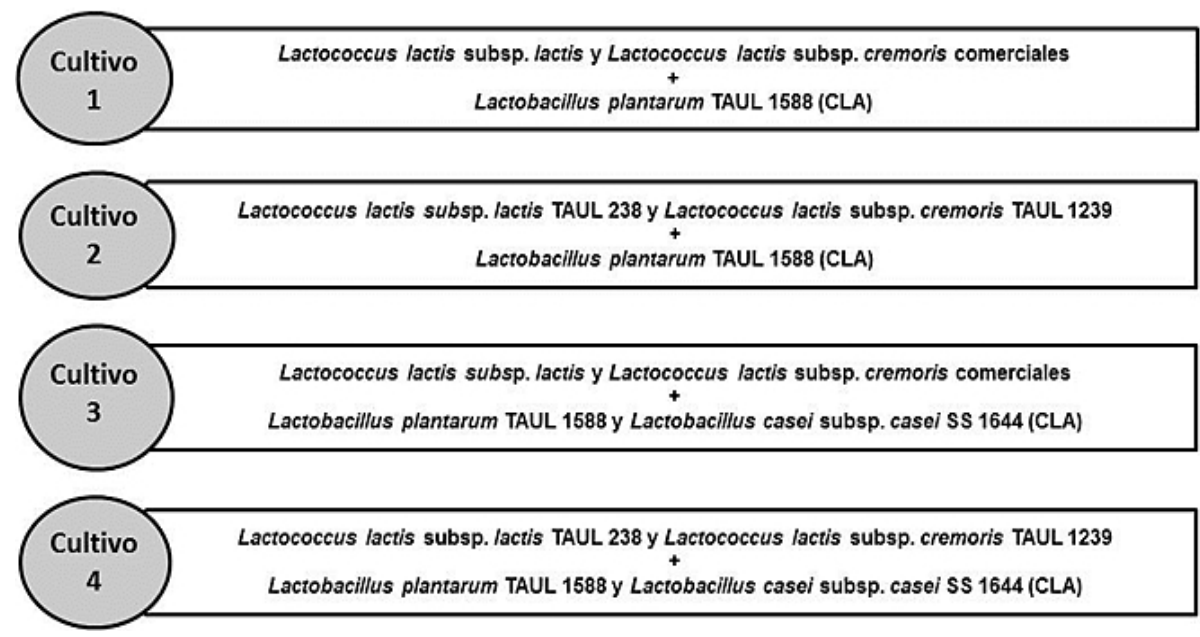

Figura 4. Descripción de cada cultivo diseñado con cepas de Lactococcus lactis (comerciales y autóctonas) y las cepas de Lactobacillus productoras de CLA.

En el caso de del isómero trans-10,cis-12 $\mathrm{C}_{18: 2}$, no se observaron diferencias estadísticamente significativas $(P>0,05)$ entre los distintos cultivos a lo largo de la incubación. Sin embargo, el contenido en el isómero trans-9,trans-11 $\mathrm{C}_{18: 2}$ presentó diferencias estadísticamente significativas $(P \leq 0,01)$ entre los cuatro cultivos a las 72 horas de incubación, observándose la mayor concentración del mismo en el caso del cultivo 2. Con respecto al CLA total producido por los cultivos, y al igual que en el estudio descrito anteriormente con respecto a las seis cepas de Lactobacillus, la mayor producción de CLA total se produjo a las 48 horas de incubación, momento a partir del cual la concentración de dicho compuesto comenzó a disminuir significativamente $(P \leq 0,05)$. Cabe resaltar que las mayores concentraciones de CLA a las $48 \mathrm{~h}$ fueron producidas por el cultivo 2 y por el cultivo 1 . En el estudio llevado a cabo en medio de cultivo como medio de crecimiento, estos cultivos produjeron casi el doble de la concentración de CLA que produjo individualmente la cepa de Lactobacillus plantarum TAUL 1588 en el mismo medio. En este contexto, Andrade et al. (2012) han indicado que existen diversos factores ambientales que pueden afectar a la síntesis de CLA por parte de las bacterias ácido lácticas, explicando el motivo por el cual la presencia de cepas de Lactococcus lactis en este estudio hicieron más propicias las condiciones para la producción de CLA por parte de la cepa Lactobacillus plantarum TAUL 1588. En relación con que las cepas de Lactococcus lactis fuesen autóctonas o comerciales, este hecho no afectó significativamente $(P>0,05)$ a la producción de CLA por parte de los cultivos, al menos hasta las 72 h de incubación. En el caso del cultivo 2, constituido por las cepas autóctonas de Lactococcus lactis, el descenso en la concentración de CLA tras 72 h de incubación fue menos acusada que en el resto de los cultivos estudiados. De igual manera, en lo que respecta a la combinación de cepas productoras de CLA de diferentes especies, este hecho no incrementó la 
concentración de CLA en medio de cultivo para ninguno de los tiempos de incubación analizados.

Por el contrario, el contenido en CLA total y de cada uno de los isómeros producidos por los cuatro cultivos diseñados en los distintos tiempos de incubación fue diferente en leche desnatada con respecto al observado en el medio de cultivo. En base a las consideraciones indicadas previamente en la presente Tesis en relación con la importancia que tienen los distintos isómeros CLA sobre la salud humana, cabe señalar que el contenido en el isómero cis-9,trans-11 $\mathrm{C}_{18: 2}$ presentó diferencias estadísticamente significativas $(P \leq 0,05)$ entre los cultivos a las 48 y a las $72 \mathrm{~h}$ de incubación. Durante este último tiempo de incubación, los cultivos 1, 2 y 3 produjeron una mayor concentración de este isómero, mientras que en el caso del cultivo 4 se observó un descenso de 9,40 $\mu \mathrm{g} / \mathrm{mL}$ con respecto a la concentración observada a las $48 \mathrm{~h}$. La mayor concentración del isómero trans-9,trans-11 $\mathrm{C}_{18: 2}$ producida a las $72 \mathrm{~h}$ de incubación por el cultivo 4 podría estar relacionada tanto con su sintesis a partir del ácido linoleico como con una mayor interconversión del isómero cis-9, trans-1 $1 \mathrm{C}_{18: 2}$ hacia éste, coincidiendo con lo descrito por Ogawa et al. (2005). Este hecho a su vez explicaría el descenso anteriormente observado en la concentración del isómero cis-9,trans-11 $\mathrm{C}_{18: 2}$ producida por el cultivo 4 tras $72 \mathrm{~h}$ de incubación en comparación con los otros cultivos.

De igual manera, tal y como había sido observado cuando se estudió la producción de CLA por parte de las cepas de Lactobacillus en leche desnatada, ninguno de los cultivos diseñados tuvo la capacidad de sintetizar el isómero trans-10, cis-12 $\mathrm{C}_{18: 2}$.

Por último, es importante señalar que la mayor concentración de CLA total se observó a las $72 \mathrm{~h}$ de incubación, la cual fue producida por el cultivo 4, constituido por cepas autóctonas de Lactococcus lactis y las cepas productoras de CLA Lactobacillus plantarum TAUL 1588 y Lactobacillus casei subsp. casei SS 1644. Sin embargo, el menor contenido de CLA fue descrito para los cultivos 1 y 2 , no incluyendo ninguno de ellos la cepa Lactobacillus casei subsp. casei, la cual resultó ser en el estudio de las cepas, la especie más eficiente sintetizando CLA en leche desnatada en comparación con las cepas de Lactobacillus plantarum. En consecuencia, la presencia de Lactobacillus casei subsp. casei SS 1644 en leche desnatada conllevó a un incremento en la producción de CLA en este medio. Así mismo, la presencia de cepas autóctonas de Lactococcus lactis mejoró significativamente $(P \leq 0,05)$ la producción de CLA en la leche desnatada en el caso del cultivo 4 con respecto al cultivo 3 y del cultivo 2 en relación con el cultivo 1 .

\subsection{Evolución de los parámetros físico-químicos y de los principales grupos microbianos de los quesos de oveja elaborados con diferentes cultivos productores de CLA a lo largo de la maduración}

En base a los resultados descritos anteriormente, los quesos de oveja fueron elaborados empleando como materia prima leche de oveja procedente de una de las granjas que fueron estudiadas en el capítulo 1 de la presente Tesis y cuya recogida fue programada para el mes de abril, periodo en cual las ovejas fueron alimentadas principalmente bajo régimen de pastoreo. Así mismo, teniendo en cuenta la capacidad de los co-cultivos diseñados para producir CLA in vitro utilizando leche desnatada como medio de crecimiento, fueron elaborados 4 lotes de queso, los cuales se describen a 
continuación. El lote 1 o control se elaboró con el cultivo iniciador que incluyó las cepas autóctonas de Lactococcus lactis subsp. lactis TAUL 238 y Lactococcus lactis subsp. cremoris TAUL 1239, ninguna de ellas productora de CLA. Los lotes 2 y 3 se elaboraron con los cultivos constituidos por estas mismas cepas de Lactococcus lactis y una de las cepas de Lactobacillus productoras de CLA, Lactobacillus plantarum TAUL 1588 y Lactobacillus casei subsp. casei SS 1644, respectivamente. Finalmente, el lote 4 fue elaborado empleando el cultivo formado por las cepas de Lactococcus lactis más las dos cepas de Lactobacillus productoras de CLA (Figura 5).

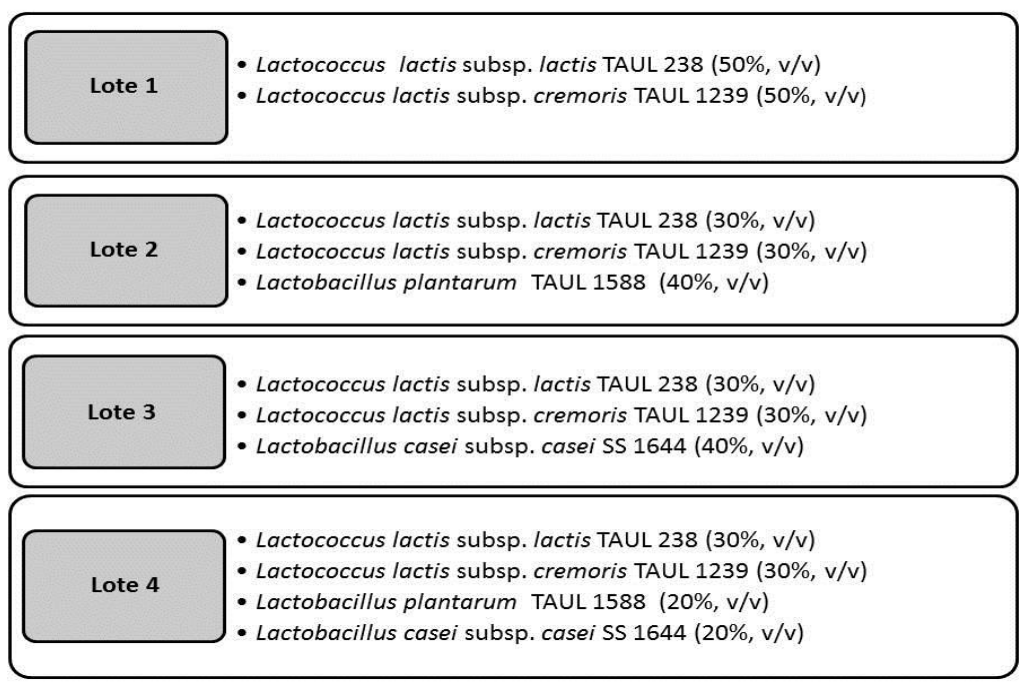

Figura 5. Cultivos autóctonos empleados en la elaboración de los lotes de queso de oveja. Proporción individual de cada cepa con respecto a la proporción total de las cepas que componen cada cultivo.

Los resultados que son discutidos en detalle en este apartado aparecen recogidos en el capítulo 5 de la presente Tesis.

Los parámetros físico-químicos de los quesos juegan un papel fundamental durante la maduración de los mismos al influir no sólo sobre el desarrollo de la microbiota presente sino también sobre la actividad enzimática que cataliza los diferentes procesos bioquímicos que se desarrollan durante la misma y que van a ser los responsables de las características finales que presentan los quesos (Fox et al., 2016).

Los diferentes cultivos empleados en la elaboración de los cuatro lotes de queso no tuvieron un efecto significativo $(P>0,05)$ sobre los diferentes parámetros físico-químicos para el mismo tiempo de maduración. Únicamente en el caso de la acidez titulable, sus valores para los lotes 3 y 4 (los cuales incluyeron en el cultivo la cepa de Lactobacillus casei subsp. casei SS 1644) fueron superiores a los observados en los otros dos lotes de queso al cabo de 90 y 180 días de maduración. Este hecho pudo venir determinado por la 
mayor capacidad acidificante presentada por esta cepa con respecto a la de Lactobacillus plantarum TAUL 1588, tal y como fue descrito en estudios previos (González et al., 2015; Herreros et al., 2003).

De igual manera, todos los parámetros físico-químicos analizados en este trabajo mostraron un comportamiento muy similar a lo largo de la maduración en los 4 lotes de queso. A los 90 días el valor de $\mathrm{pH}$ fue ligeramente superior al que presentaron los quesos al inicio de la maduración, permaneciendo luego constante o disminuyendo ligeramente hasta el final de la misma. Mejor indicador que el pH de la actividad microbiana en los quesos durante la maduración es la acidez titulable, cuyos valores se incrementaron durante los 6 primeros meses para luego disminuir ligeramente. Además, la acidificación que tuvo lugar durante el proceso de maduración de los lotes de queso contribuyó a la pérdida de humedad de éstos como fue reflejado en la correlación negativa observada entre los valores de la acidez y de la humedad ( $\rho=-0,84 ; P \leq 0,001)$. El contenido en humedad descendió a lo largo de la maduración alcanzando valores inferiores al 30\% en todos los lotes de queso. Los valores de la actividad del agua siguieron una tendencia muy parecida, presentando valores medios de 0,989 al inicio de la maduración y de 0,915 al final de la misma. Así mismo, se observó que conforme la relación sal/humedad aumentaba, los valores de la actividad del agua disminuian $(\rho=-0,87 ; P \leq 0,01)$. En lo referente a los valores observados para estos parámetros fueron similares a los descritos para otros quesos de oveja madurados (Guinee y Fox, 2004).

Cabe destacar que en ninguno de los lotes de queso se observaron diferencias significativas $(P>0,05)$ en el contenido en grasa y proteína (expresados sobre porcentaje de materia seca) durante la maduración. Este hecho fue debido a la estandarización de la materia prima usada en la fabricación (mismo productor y misma época), ya que ambos parámetros son los que mayores variaciones sufren durante el periodo de lactación. Los valores observados para estos dos parámetros fueron similares a los descritos en queso de oveja (Fernández et al., 2012).

En relación con la evolución de los principales grupos microbianos, se observó que tras la adición de los cultivos a la leche pasterizada, se incrementaron los recuentos de la microbiota aerobia mesófila, bacterias ácido lácticas en general y lactobacilos en particular durante la etapa inicial de la maduración. En este contexto, Diezhandino et al. (2015) han indicado que el aumento en los recuentos microbianos se debe tanto a la retención física de los microorganismos en la cuajada como a la multiplicación microbiana durante la fase de coagulación que tiene lugar en el proceso de elaboración de los quesos.

Los mayores recuentos en microbiota aerobia mesófila se observaron a los 2 días de maduración (10 log UFC/mL), excepto en el caso del lote 3 , en el cual los recuentos máximos (11 log UFC/mL) se detectaron a los 90 días. A partir de este momento, estos recuentos descendieron hasta el final de la maduración, alcanzando valores entre 7 (lote 1) y 9 (lote 3) $\log \mathrm{UFC} / \mathrm{mL}$.

Los recuentos de bacterias ácido lácticas a lo largo de la maduración fueron similares a los descritos previamente para la microbiota aerobia mesófila, aspecto que refleja que las bacterias ácido lácticas fueron los microorganismos predominantes en los cuatro lotes de queso. Al término de la maduración, los recuentos de bacterias ácido lácticas fueron del orden de 1-2 unidades logaritmicas inferiores a los observados a los 2 días de maduración. Este hecho pudo ser debido a que se produjo un importante 
incremento en los valores de la relación sal/humedad en los quesos a los 90 días de maduración, lo que pudo tener un efecto inhibitorio en el crecimiento de las bacterias ácido lácticas. De hecho, fue observada una correlación negativa $(\rho=-0,57 ; P \leq 0,01)$ entre los recuentos de bacterias ácido lácticas y la relación sal/humedad de los quesos.

Comparando la evolución de los lactobacilos en los puntos de muestreo realizados, se pudo observar que en los lotes de queso elaborados con los cultivos que incluyeron la cepa de Lactobacillus plantarum TAUL 1588 (lotes 2 y 4) los mayores recuentos se alcanzaron a los 90 días, mientras que en el lote 3 , fabricado con el cultivo que incorporaba la cepa Lactobacillus casei subsp. casei SS 1644, los recuentos máximos se observaron tras 2 días de maduración, disminuyendo a partir de ese momento hasta el final de la misma. En el lote 1 no se detectaron recuentos de lactobacilos hasta los 180 días de maduración, siendo los mismos más bajos que los observados en los otros lotes de queso, consecuencia de la no inclusión de cepas de Lactobacillus en el cultivo iniciador.

Finalmente, los recuentos de Enterobacteriaceae son considerados como un buen indicador de las condiciones higiénicas durante el proceso de elaboración de los quesos (Renes et al., 2014). Las excelentes prácticas higiénicas llevadas a cabo durante la elaboración de los cuatro lotes de queso se vieron reflejadas en estos recuentos, donde únicamente fueron detectados en las muestras de 2 días de maduración y con valores inferiores a $4 \log \mathrm{UFC} / \mathrm{mL}$. A estos bajos recuentos también contribuyeron las condiciones de acidez y fuerza iónica instauradas en los quesos, como demuestran las correlaciones negativas observadas entre los recuentos de Enterobacteriaceae y los valores de acidez ( $\rho=-$ 0,73; $P \leq 0,01)$ así como entre los recuentos de Enterobacteriaceae y la relación sal/humedad ( $\rho=-0,95 ; P \leq 0,01)$, coincidiendo con lo descrito por otros autores en queso de oveja (Piras et al., 2013).

\subsection{Efecto de cultivos productores de CLA y del tiempo de maduración sobre el perfil de ácidos grasos del queso de oveja}

De acuerdo con los planteamientos que se han venido realizando en esta Tesis, se llevó a cabo el estudio del perfil de ácidos grasos de los cuatro lotes de queso elaborados con los diferentes cultivos autóctonos a lo largo de la maduración (2, 90, 180 y 240 días). El objetivo principal de este estudio fue conocer si los cultivos seleccionados por su capacidad para sintetizar CLA in vitro también presentaban esta capacidad cuando se utilizaban en la elaboración de los quesos de oveja.

Los resultados que a continuación son discutidos se presentan en el capítulo 4 de la presente Tesis.

El tiempo de maduración de los quesos no tuvo un efecto significativo $(P>0,05)$ sobre el contenido de los 86 ácidos grasos analizados en este estudio. De manera similar a este trabajo, varios autores han confirmado que el tiempo de maduración no afecta al perfil en ácidos grasos de los quesos (Bodas et al., 2010; dos Santos et al., 2012; Luna et al., 2007). En base a esto, es importante resaltar que la matriz del queso puede proporcionar estabilidad a los ácidos grasos biactivos, asegurando que sus concentraciones serán similares tanto en quesos frescos como en quesos madurados.

Sin embargo, el tipo de cultivo utilizado en la elaboración de queso de oveja si influyó significativamente $(P \leq 0,05)$ sobre la concentración de los ácidos grasos. En todos 
los lotes de queso, los ácidos grasos saturados fueron el grupo mayoritario representando el $73 \%$ del contenido total de ácidos grasos. El ácido palmítico $\left(\mathrm{C}_{16: 0}\right)$ seguido del ácido mirístico $\left(\mathrm{C}_{14: 0}\right)$ fueron los predominantes dentro del grupo de los ácidos grasos saturados. Estos resultados fueron similares a los descritos por Bodas et al. (2010) en su estudio del perfil de ácidos grasos en quesos de oveja elaborados con leche procedente de rebaños alimentados con diferentes dietas. Cabe destacar que el descenso observado en la concentración de ácido palmítico y mirístico del lote 4 en relación con los otros lotes de queso puede ser considerado como positivo desde el punto de vista nutricional. Sin embargo, hay que mencionar que la relación entre el consumo de ácidos grasos saturados y el desarrollo de enfermedades cardiovasculares es controvertida debido a que los datos observacionales procedentes de diversos estudios no han permitido probar la relación causa-efecto (Parodi, 2004).

Uno de los resultados más relevantes de este estudio fue que la combinación de las dos cepas de Lactobacillus en el cultivo empleado en la elaboración del lote 4 condujo a una mayor concentración de los ácidos grasos $\mathrm{C}_{6: 0}, \mathrm{C}_{8: 0}$ y $\mathrm{C}_{10: 0}$, los cuales han sido asociados con efectos beneficiosos en la salud humana (Nagao y Yanagita, 2010; Parodi, 2004). Además, estos ácidos grasos de cadena corta juegan un papel interesante en las características sensoriales de los quesos debido a que presentan umbrales de percepción más bajos que los ácidos grasos de cadena larga (Laskaridis et al., 2013).

Cabe destacar que el lote de queso elaborado con la combinación de ambas cepas de Lactobacillus mostró la menor concentración de $\mathrm{C}_{17: 0}$ así como de ácidos grasos de cadena ramificada en comparación con los lotes elaborados con las cepas de Lactobacillus individualmente. Este hecho mostró que el metabolismo de los cultivos utilizados para elaborar queso juega un papel importante en el contenido de estos ácidos grasos minoritarios, confirmando la relación entre la producción de ácidos grasos de cadena impar y ramificada y el tipo de microorganismo involucrado en el proceso de fermentación.

La proporción total de ácidos grasos monoinsaturados fue significativamente $(P \leq$ $0,05)$ diferente entre los distintos lotes de queso estudiados. De nuevo el lote 4 presentó una mayor proporción $(24,64 \%)$ de estos ácidos grasos en comparación con el lote 1 $(22,68 \%)$. Dentro de este grupo de ácidos grasos, el ácido oleico $\left(\mathrm{C}_{18: 1}\right.$ cis-9) fue el mayoritario, constituyendo entre el $78-80 \%$ del total de los ácidos grasos monoinsaturados en los cuatro lotes de queso. En el presente estudio se observó que el uso de cepas autóctonas productoras de CLA generó un incremento en la proporción de los isómeros cis$\mathrm{C}_{18: 1}$, principalmente del isómero cis-9 en comparación con el lote control. Estos resultados difieren de los descritos por Mohan et al. (2013), los cuales observaron que el queso Cheddar elaborado empleando una cepa productora de CLA presentaba una menor proporción de ácido oleico en comparación con el lote control. De igual manera, en el presente estudio se comprobó que el empleo de cepas productoras de CLA en los cultivos utilizados en la elaboración de los quesos incrementaron la proporción de los ácidos grasos trans- $\mathrm{C}_{18: 1}$, siendo el ácido vacénico el isómero mayoritario, representando aproximadamente el 44\% del total de los ácidos grasos trans- $\mathrm{C}_{18: 1}$. Estos resultados fueron similares a los descritos por dos Santos et al. (2012) y Taboada et al. (2015) para queso de cabra elaborado con cepas productoras de CLA.

La presencia de una concentración elevada de ácido vacénico en queso es deseable debido a que este ácido graso puede ser utilizado para la síntesis endógena (mediante la 
enzima estearoil-CoA) del ácido ruménico en humanos, proporcionando los efectos beneficiosos para la salud humana que son atribuidos a este isómero CLA (Turpeinen et al., 2002).

De igual manera, el tipo de cultivo empleado influyó en la proporción de ácidos grasos poliinsaturados de los quesos de oveja estudiados. Dentro de este grupo de ácidos grasos, destacan el CLA y los ácidos grasos omega-3, los cuales han sido relacionados con efectos beneficiosos sobre la salud humana, siendo su ingesta a través de los alimentos esencial para alcanzar tales efectos positivos (Swanson et al., 2012; Yang et al., 2015). En este sentido, el lote 4 elaborado con una combinación de las cepas Lactobacillus plantarum TAUL 1588 y Lactobacillus casei subsp. casei SS 1644 presentó una mayor concentración de CLA total que el resto de los lotes estudiados. Este hecho podría ser debido a que la combinación de las dos cepas generaría condiciones más favorables para que tuviese lugar la actividad de la linoleato isomerasa de ambas cepas. Tal y como ha sido mencionado en apartados anteriores de esta Tesis, Gorissen et al. (2011) señalaron que la actividad de la linoleato isomerasa en las bacterias ácido lácticas es dependiente de factores ambientales tales como el pH o la temperatura, así como del tipo de cepa. Desafortunadamente, los mecanismos y factores que pueden afectar a la sintesis de CLA por parte de las bacterias ácido lácticas son inciertos y es necesario llevar a cabo más estudios.

El método cromatográfico empleado en este estudio permitió detectar diversos isómeros CLA en los cuatro lotes de queso de oveja. El ácido ruménico fue el isómero mayoritario detectado en todos los lotes, representando más del 80\% del CLA total. Este hecho mostró concordancia con lo descrito por otros autores en queso de oveja (Mele et al., 2011; Zlatanos et al., 2002). Adicionalmente, la proporción de CLA total observada en el lote 4 fue similar a la descrita por El-Salam y El-Shibiny (2014) en queso.

En consecuencia destaca el gran interés que supone la combinación de estas cepas productoras de CLA en la elaboración de queso, al generar una mayor proporción de este ácido graso biactivo en comparación con el lote control.

Cabe señalar que el ácido a-linolénico fue el ácido graso omega-3 mayoritario en todos los lotes de queso, siendo los lotes de queso elaborados con los cultivos que incluyeron la cepa de Lactobacillus casei subsp. casei SS 1644 los que presentaron mayor proporción de este ácido graso. Por contra, en el lote 2 elaborado con el cultivo incluyendo la cepa de Lactobacillus plantarum TAUL 1588, la proporción de ácido a-linolénico fue similar a la observada en el lote control. Por tanto, y de acuerdo con estos resultados, la cepa de Lactobacillus casei subsp. casei SS 1644 podría ser la principal responsable del mayor contenido en ácido a-linolénico observado en estos quesos.

En general, los cambios descritos previamente en el perfil de ácidos grasos de los quesos dieron lugar a diferencias significativas $(P \leq 0,05)$ en los índices de ácidos grasos relacionados con la salud humana y que han sido objeto del presente estudio. Altos valores en la relación omega-6/omega-3 y en el índice de aterogenicidad en los alimentos, si bien no conllevan que su consumo tenga que ser evitado, implicarian que este ha de ser moderado (Taboada et al., 2015). Cabe señalar que en el lote control, los valores observados para la relación omega-6/omega-3 y en el índice de aterogenicidad fueron significativamente $(P \leq 0,05)$ superiores a los detectados en los lotes elaborados con cepas autóctonas con capacidad para sintetizar CLA. Estos resultados mostraron que el uso de estas cepas autóctonas, previamente seleccionadas como productoras de CLA in vitro, en la 
elaboración de queso da lugar a un perfil en ácidos grasos beneficioso para la salud humana (más aún cuando se emplea una combinación de ellas) en comparación con la proporción de ácidos grasos observada en el queso de oveja elaborado con el cultivo que no incluyó cepas con mencionada capacidad.

Adicionalmente, se llevó a cabo un análisis de componentes principales para visualizar de una manera más gráfica el perfil de ácidos grasos que presentaron los cuatro lotes de queso de oveja a lo largo de la maduración. Se identificaron 3 grupos a lo largo de los dos primeros componentes, los cuales explicaron el $91 \%$ del total de la variación observada. Los quesos elaborados con la combinación de las dos cepas fueron situados en el lado derecho del gráfico y estuvieron correlacionados con la proporción de ácidos grasos monoinsaturados cis y trans, CLA total y ácidos grasos poliinsaturados. Por contra, los quesos control fueron localizados en el lado izquierdo del gráfico y estuvieron asociados con el contenido en ácidos grasos saturados, la relación omega-6/omega-3 y el índice de aterogenicidad. Los quesos pertenecientes a los lotes 2 y 3 formaron un único grupo con valores intermedios entre el lote 1 y el lote 4 .

Estos resultados permitieron confirmar que el tipo de cultivo empleado en la elaboración de los quesos fue el factor que más afectaba al perfil de ácidos grasos de los quesos de oveja estudiados y que las cepas previamente detectadas como productoras de CLA in vitro también presentan esta capacidad cuando se usan combinadas en un cultivo. Estos estudios se consideran de gran interés para la industria quesera al contribuir al desarrollo de productos lácteos con un mejor perfil nutricional a partir de leche de oveja.

\subsection{Efecto de los diferentes cultivos diseñados sobre el perfil de aminoácidos libres, la microestructura y el contenido en aminas biógenas de los quesos de oveja a lo largo de la maduración}

Las bacterias ácido lácticas que son empleadas habitualmente en la elaboración de queso, en especial las utilizadas como cultivos adjuntos, juegan un papel muy importante en la proteólisis que tiene lugar durante la maduración del queso debido a que estas bacterias contienen proteinasas y peptidasas que pueden dar lugar a la producción de aminoácidos libres (Fox et al., 2016). Algunos de estos aminoácidos a su vez pueden servir como sustrato en reacciones secundarias catabólicas, llevadas a cabo por estas bacterias ácido lácticas, que pueden dar lugar a la síntesis de compuestos como el GABA y la ornitina con propiedades beneficiosas en la salud humana (Adeghate y Ponery, 2002; Diana et al., 2014b; Sugino et al., 2008). No obstante, los aminoácidos libres también pueden sufrir reacciones de descarboxilación por acción de las bacterias ácido lácticas que conducen a la sintesis de aminas biógenas, cuyo consumo en elevadas concentraciones puede tener efectos negativos en la salud humana (Linares et al., 2011; Manca et al., 2015).

En base a lo expresado anteriormente, se llevó a cabo un estudio que permitió evaluar el efecto de los diferentes cultivos empleados en la elaboración de los cuatro lotes de queso de oveja, descritos en el apartado anterior, sobre el perfil de aminoácidos libres, con especial énfasis en el GABA y la ornitina, la microestructura y el contenido en aminas biógenas de los quesos de oveja a lo largo de la maduración (2, 90, 180 y 240 días). 
Los resultados que son discutidos a continuación, en relación con el estudio descrito en este apartado, aparecen recogidos en el capítulo 5 de la presente Tesis.

El tiempo de maduración de los quesos conllevó a un incremento significativo $(P \leq$ 0,001 ) en la concentración de los aminoácidos libres totales de los cuatro lotes de queso. Este aumento fue debido principalmente a la actividad proteolítica de las cepas que formaron parte de los cultivos (González et al., 2015; Herreros et al., 2003), dando lugar a que la concentración de aminoácidos libres totales fuera superior a la observada por Poveda et al. (2004) en queso de oveja elaborado con diferentes cultivos iniciadores y con un tiempo de maduración similar.

La proteólisis que tuvo lugar durante la maduración de los cuatro lotes de queso queda reflejada en las imágenes obtenidas cuando se analizó la microestructura de los cuatro lotes de queso utilizando el método basado en la microscopía confocal de barrido láser. La microestructura observada en cada una de las imágenes obtenidas para los cuatro lotes estudiados y mismo tiempo de maduración fue muy similar. Al inicio de la maduración (2 dias), se observó una matriz proteica continua y fibrosa conteniendo glóbulos grasos que presentaban una forma irregular. La fase proteica y grasa mostraron una ligera orientación lineal, al igual que también fue observado por Auty et al. (2001) en queso Cheddar, atribuyendo este hecho a la etapa de prensado que tiene lugar durante el proceso de elaboración de estos quesos. Por un lado, conforme transcurrió el tiempo de maduración, la matriz proteica fue presentando gradualmente una estructura amorfa, como consecuencia de la proteólisis. Por otro lado, la coalescencia de los glóbulos grasos a lo largo de la maduración dio lugar a la formación de grandes partículas de grasa y la actividad lipolítica que tuvo lugar contribuyó a la salida de parte de la grasa de los glóbulos. Estos resultados fueron similares a los observados en el análisis de la microestructura de otros quesos (Everett y Auty, 2008; O’Reilly et al., 2003).

En lo que respecta a los distintos cultivos empleados en la elaboración de queso, éstos tuvieron un efecto significativo $(P \leq 0,001)$ en la concentración de aminoácidos libres totales. El lote 3, elaborado con el cultivo que incluyó la cepa de Lactobacillus casei subsp. casei SS 1644, fue el que presentó la mayor concentración de aminoácidos libres totales a lo largo de todo el periodo de maduración de los quesos, alcanzando unos valores al cabo de 90 días de maduración muy similares a los detectados en el resto de lotes al final de la maduración (240 días). En este sentido, Arzania et al. (2006) han señalado que la maduración se trata de un proceso que implica costes relativamente altos a la industria quesera. En consecuencia, el empleo de este cultivo podría reducir el tiempo de maduración del queso de oveja no solo proporcionando beneficios tecnológicos sino también económicos para las industrias.

Los lotes 1,2 y 4 no presentaron diferencias significativas $(P>0,05)$ en la concentración de aminoácidos libres totales entre ellos hasta el final de la maduración. En este momento, el lote 2, elaborado con el cultivo formado por las cepas autóctonas de Lactococcus lactis y el Lactobacillus plantarum TAUL 1588, presentó una concentración de aminoácidos libres totales similar a la descrita en el lote 1 que fue elaborado con el cultivo que únicamente incluía las cepas de Lactococcus lactis. Sin embargo, el lote 4, elaborado con las cuatro cepas autóctonas presentó una concentración mayor de aminoácidos libres totales que los lotes 1 y 2 aunque inferior a la del lote 3 . 
En general, de los 21 aminoácidos analizados en los cuatro lotes de queso a lo largo de la maduración, los mayoritarios fueron leucina, ácido glutámico, fenilalanina, prolina, alanina y valina, los cuales representaron aproximadamente el $60 \%$ del total de aminoácidos libres. Por el contrario, tirosina, histidina, glicina, triptófano y arginina fueron los aminoácidos libres minoritarios, representando menos del 5\% del total de aminoácidos libres analizados. La información disponible en la literatura en relación con los aminoácidos libres mayoritarios y su concentración en queso de oveja varía ampliamente (Madrau et al., 2006; Mangia et al., 2008; Poveda et al., 2015). En este hecho podrian haber intervenido las diversas bacterias ácido lácticas empleadas en la elaboración de los quesos debido a que éstas presentan un complejo sistema proteolítico y dependiendo de la especie implicada, este sistema puede estar constituido por diferentes proteinasas y peptidasas (Fox et al., 2016). Adicionalmente, Poveda et al. (2004) han indicado que la composición de las caseínas es diferente dependiendo del tipo del que se trate; así, las caseínas as presentan un contenido alto en leucina, fenilalanina y valina, mientras que las caseínas $\beta$ tienen un elevado contenido en prolina. Por consiguiente, dependiendo del sustrato específico de las enzimas presentes en el sistema proteolítico de las bacterias ácido lácticas empleadas como cultivos, el tipo y la concentración de aminoácidos libres en el queso serán diferentes.

La escasa información disponible sobre el efecto de cultivos autóctonos en la concentración de GABA y ornitina a lo largo de la maduración del queso de oveja hacen que los resultados obtenidos en este estudio sean muy relevantes. El tiempo de maduración fue un factor importante en la concentración final de GABA en los cuatro lotes de queso, ya que se incrementó más de 80 veces a lo largo de la misma. El lote 1 fue el que presentó la mayor concentración de GABA tras 240 días de maduración seguido de los otros tres lotes de queso, entre los cuales no se observaron diferencias significativas $(P>$ 0,05). La importancia de este estudio vino determinada por la alta concentración de GABA detectada en todos los lotes al final de la maduración. En relación con la dosis de GABA que conlleve efectos beneficiosos para la salud de los consumidores, se ha descrito que es necesaria una ingesta oral diaria de $26,4 \mathrm{mg}$ para ejercer un efecto positivo en el tratamiento de ciertos desórdenes neurológicos (Okada et al., 2000). Por consiguiente, sería necesario consumir $15 \mathrm{~g}$ de queso al día del lote 1 y $23 \mathrm{~g}$ de los otros tres lotes para alcanzar esta dosis recomendada de GABA. Este hecho implica que pequeñas porciones de estos quesos proporcionarian la concentración necesaria de GABA para alcanzar los efectos fisiológicos indicados anteriormente. De igual manera, en otro estudio llevado a cabo por Pouliot-Mathieu et al. (2013) observaron que una ingesta de diaria de $50 \mathrm{~g}$ de un queso experimental (conteniendo $16 \mathrm{mg}$ de GABA) producía un descenso de la presión sanguínea en humanos. En base a los resultados obtenidos en nuestro estudio, el consumo de $50 \mathrm{~g}$ de queso al día de los diferentes lotes elaborados en este trabajo proporcionaría entre $60 \mathrm{mg}$ y $90 \mathrm{mg}$ de GABA. No obstante, serian necesarios otros estudios, fuera del ámbito de esta Tesis, para profundizar en estos aspectos.

En lo que respecta a la ornitina, la presencia de este compuesto en los alimentos está ganando interés debido a las funciones bioactivas en la salud humana que han sido descritas en varios estudios (Kurata et al., 2012; Sugino et al., 2008). Actualmente, no hay disponible información sobre la dosis efectiva de la ornitina para alcanzar los beneficios fisiológicos que se le han atribuido. Lo que si se conoce es que la ornitina puede ser 
sintetizada por la actividad enzimática de las bacterias ácido lácticas sobre la arginina y la citrulina durante la maduración de los quesos (Diana et al., 2014b). En este sentido, en los cuatro lotes de queso se produjo un incremento $(P \leq 0,001)$ en la concentración de ornitina a lo largo de la maduración. Así mismo, no se observaron diferencias significativas $(P>$ $0,05)$ en la concentración de ornitina entre los cuatro lotes de queso analizados hasta los 240 días de maduración. Como fue descrito previamente para el GABA, el lote 1 fue el que presentó la mayor concentración de ornitina seguido de los lotes 2,3 y 4, entre los cuales no se observaron diferencias $(P>0,05)$. Las concentraciones de ornitina observadas al final de la maduración en los cuatro lotes fueron superiores a las señaladas por Diana et al. (2014b) en queso de oveja. Los resultados descritos hasta el momento, abren la posibilidad de llevar a cabo más estudios con estos cultivos para el posible desarrollo de quesos funcionales.

Finalmente, se analizó el efecto del cultivo empleado y del tiempo de maduración sobre el contenido en aminas biógenas de los cuatro lotes de queso. Durante el transcurso del tiempo de maduración, el contenido total de aminas biógenas aumentó significativamente $(P \leq 0,001)$, siendo estos valores muy similares a los descritos por otros autores en queso de oveja (Renes et al., 2014; Schirone et al., 2013). Es importante indicar que la concentración máxima permitida de aminas biógenas en productos lácteos no ha sido establecida todavía desde un punto de vista legislativo y que la mayoría de los trabajos de investigación se han centrado casi exclusivamente en el estudio de la histamina y de la tiramina, debido a que éstas son las aminas biógenas que con más frecuencia se asocian con intoxicaciones alimentarias, así como las más abundantes en queso (Linares et al., 2016). En el presente estudio, no se detectó la presencia de histamina en ninguno de los lotes de queso analizados, mientras que las concentraciones de tiramina oscilaron entre $308,65 \mathrm{mg} / \mathrm{kg}$ de queso y $585,47 \mathrm{mg} / \mathrm{kg}$ queso al final de la maduración, encontrándose estos valores dentro los límites máximos tolerables (100-800 $\mathrm{mg} / \mathrm{kg}$ de queso) indicados por ten Brink et al. (1990). No obstante, es necesario resaltar que la cadaverina y la putrescina, las cuales no han sido asociados con intoxicaciones alimentarias, pueden aumentar la toxicidad de la histamina y la tiramina. En base a esto, el contenido total de aminas biógenas no debería exceder la cantidad de $900 \mathrm{mg} / \mathrm{kg}$ de queso establecida por Valsamaki et al. (2000), y en este sentido, ninguno de los lotes de quesos estudiados excede este límite, por lo que no supondrían un riesgo para la salud del consumidor.

En relación con el efecto del cultivo empleado en la elaboración de queso, el lote 3, elaborado con el cultivo que incluyó la cepa de Lactobacillus casei subsp. casei, fue el que presentó la mayor concentración de aminas biógenas totales a lo largo de la maduración. Simultáneamente, y como ha sido mencionado previamente, este lote fue el que mostró la mayor concentración de aminoácidos libres totales. Estos resultados fueron coincidentes con los descritos por Novella-Rodríguez (2003), quienes indicaron que el aumento de la proteólisis durante la maduración de los quesos, puede conducir a un incremento del contenido en aminas biógenas. Otro resultado destacable en el presente estudio fue que el lote 2 elaborado con el cultivo que incluía la cepa de Lactobacillus plantarum TAUL 1588 presentó la menor concentración de aminas biógenas totales, seguido de los lotes 1 y 4 . El hecho de que el lote 4 presente una menor concentración de aminas biógenas totales respecto al lote 3 , podría estar relacionado con la capacidad de la cepa Lactobacillus 
plantarum TAUL 1588 para degradar las aminas biógenas producidas por las otras cepas de bacterias ácido lácticas empleadas en los cultivos. Guarcello et al. (2016) han indicado que la existencia de cepas de Lactobacillus con capacidad para degradar aminas biógenas abre nuevas lineas de investigación para aumentar la disponibilidad de cultivos adjuntos para elaborar quesos. Aun así, sería necesario llevar a cabo más estudios con la cepa de Lactobacillus plantarum TAUL 1588 para demostrar si realmente presenta la capacidad para degradar aminas biógenas.

La información disponible sobre las aminas biógenas mayoritarias en queso de oveja es variable al igual que en el caso de los aminoácidos libres totales. Esta variabilidad puede ser debida a que el tipo y concentración de aminas biógenas detectadas en los quesos dependen del tipo de queso que se trate, así como de múltiples factores involucrados en la formación y acumulación de éstas (Renes et al., 2014). Los lotes 1 y 2 presentaron un patrón común con respecto a la concentración de cada una de las aminas biógenas identificadas a lo largo de la maduración. En ambos lotes no se detectó la putrescina ni la feniletilamina en ninguno de los tiempos de maduración considerados, ni de tiramina al inicio de la maduración, siendo el lote 2 el que presentó menor concentración de esta amina biógena. Además, estos lotes fueron los que presentaron la menor concentración de cadaverina sin observarse diferencias $(P>0,05)$ entre ellos. Cabe destacar que el tiempo de maduración no afectó a la concentración de esta amina biógena en estos lotes.

En lo referente al lote 3, elaborado con el cultivo que incluyó la cepa de Lactobacillus casei subsp. casei, éste fue el que presentó las mayores concentraciones de todas estas aminas biógenas a lo largo de la maduración. Por contra, el lote 4 que fue elaborado con el cultivo que incluyó esta cepa conjuntamente con la cepa de Lactobacillus plantarum TAUL 1588, presentó de manera general, unas concentraciones de putrescina, feniletilamina, tiramina y cadaverina intermedias entre las observadas para el lote $3 \mathrm{y}$ los lotes 1 y 2 .

\subsection{Estudio de las caracteristicas sensoriales del queso de oveja elaborado con distintos cultivos}

En los apartados anteriores se ha descrito la posible mejora del perfil nutricional del queso de oveja. Sin embargo, también se consideró necesario el estudio de las características sensoriales de los cuatro lotes de queso por ser éste un aspecto determinante en la aceptación del queso por parte de los consumidores.

En base a estas consideraciones, se llevó a cabo un análisis del perfil de textura y del color empleando métodos instrumentales y también se analizaron las caracteristicas sensoriales de los quesos mediante un panel de catadores. Los resultados obtenidos en este estudio y que a continuación son discutidos, aparecen recogidos en el capítulo 4 de la presente Tesis.

El perfil de textura y el color de los quesos se analizaron a lo largo del tiempo de maduración, mientras que el análisis sensorial con el panel de catadores sólo fue llevado a cabo en los quesos con 180 y 240 días de maduración al ser éstos los tiempos en que se comercializa habitualmente este tipo de quesos. 
El análisis del perfil de textura permitió observar cambios significativos $(P \leq 0,05)$ en los parámetros de dureza, cohesividad, elasticidad y masticabilidad a lo largo de la maduración en los cuatro lotes de queso estudiados. De manera general, los valores de dureza aumentaron hasta los 240 días de maduración, siendo los lotes 1 y 2 los que presentaron mayor dureza. Por contra, los valores de elasticidad disminuyeron hasta la mitad al final de la misma. En el caso de la cohesividad, de manera general, los valores observados para estos parámetros disminuyeron tras 2 días de maduración, momento a partir del cual permanecieron constantes. Al final de la maduración, el efecto del cultivo empleado en la elaboración de los quesos no tuvo un efecto significativo $(P>0,05)$ en los valores observados para la elasticidad y cohesividad. Los valores de masticabilidad después del descenso producido durante los tres primeros meses, siguieron un comportamiento diferente entre lotes. Así, en los lotes 1 y 2 sus valores se incrementaron hasta los 180 días, mientras que en los lotes 3 y 4 dichos valores permanecieron sin variaciones durante el resto de la maduración, alcanzando valores similares en los cuatro lotes al final de la misma.

Con respecto al análisis del color, el tipo de cultivo empleado en la elaboración de los quesos no tuvo un efecto significativo $(P>0,05)$ en los parámetros $L^{*}, \mathrm{a}^{*} \mathrm{y} \mathrm{b}^{*}$ analizados. Por contra, el tiempo de maduración sí influyó significativamente $(P \leq 0,05)$ sobre estos parámetros. Se observó un descenso más acusado en la luminosidad ( $\left.\mathrm{L}^{*}\right)$ de los quesos de los 2 días a los 90 días de maduración, momento a partir del cual este parámetro permaneció constante o disminuyó ligeramente. De manera inversa, los valores de los parámetros $\mathrm{a}^{*} \mathrm{y}$ b* aumentaron hasta los 90 días, momento a partir del cual permanecieron constantes o disminuyeron ligeramente hasta el final de la maduración. Estos resultados reflejaron un incremento tanto en la coloración rojiza ( $\left.a^{*}\right)$ como en la coloración amarilla ( $\mathrm{b}^{*}$ ) de los quesos a lo largo de la maduración. Una tendencia muy similar ha sido descrita por otros autores (Lurueña-Martínez et al., 2010; Pinho et al., 2004) en otros estudios sobre quesos de oveja madurados.

Finalmente y por lo que respecta al análisis sensorial, en los quesos con 180 dias de maduración no se observaron cambios significativos en la mayoría de los atributos evaluados por los catadores en función del tipo de cultivo iniciador utilizado en su elaboración. El lote control (lote 1) fue el que presentó mayores valores para la intensidad de color y olor. En lo referente al atributo color, no se encontró una correlación con los resultados observados en el análisis instrumental ya que para este tiempo de maduración los valores $\mathrm{L}^{*}, \mathrm{a}^{*} \mathrm{y} \mathrm{b}^{*}$ fueron similares en los cuatro lotes. Así mismo, ninguno de los lotes presentó olores que estuvieran asociados a defectos en los quesos.

De igual manera, a los 240 días de maduración, los catadores no detectaron diferencias entre los lotes de queso con respecto a los atributos evaluados, excepto para la intensidad de olor y flavor, siendo los lotes 2 y 3 los que presentaron la menor puntuación para ambos atributos.

De cualquier modo, las diferencias observadas entre los lotes de queso fueron muy pequeñas, siendo en todos los casos inferiores a 1 punto en la escala de percepción empleada. Esta homogeneidad en los diferentes atributos sensoriales fue corroborada durante la evaluación global de los quesos, obteniéndose tanto a los 180 como a los 240 días de maduración, una puntuación media de 8,25 sobre 10, conllevando una buena aceptación por parte de los catadores. 
En definitiva, los datos obtenidos en el análisis de la textura, color y a través del panel de catadores mostraron que el empleo de diferentes cultivos adjuntos en la elaboración de los quesos no implicó cambios importantes en los parámetros sensoriales analizados.

\subsection{Referencias}

Adeghate, E., Ponery, A.S., 2002. GABA in the endocrine pancreas: cellular localization and function in normal and diabetic rats. Tissue Cell 34, 1-6.

Ando, A., Ogawa, J., Kishino, S., Shimizu, S., 2004. CLA production from ricinoleic acid by lactic acid bacteria. J. Am. Oil Chem. Soc. 80, 889-894.

Andrade, J.C., Ascençao, K., Gullón, P., Henriques, S.M.S., Pinto, J.M.S., Rocha-Santos, T.A.P., Freitas, A.C., Gomes, A.M., 2012. Production of conjugated linoleic acid by food-grade bacteria: a review. Int. J. Dairy Technol. 65, 467-481.

Auty, M.A., Twomey, M., Guinee, T.P., Mulvihill, D.M., 2001. Development and application of confocal scanning laser microscopy methods for studying the distribution of fat and protein in selected dairy products. J. Dairy Res. 68, 417-27.

Azarnia, S., Robert, N., Lee, B., 2006. Biotechnological methods to accelerate Cheddar cheese ripening. Crit. Rev. Biotechnol. 26, 121-143.

Barrett, E., Ross, R.P., Fitzgerald, G.F., Stanton, C., 2007. Rapid screening method for analyzing the conjugated linoleic acid production capabilities of bacterial cultures. Appl. Environ. Microbiol. 73, 2333-2337.

Barrett, E., Ross, R.P., O’Toole, P.W., Fitzgerald, G.F., Stanton, C., 2012. $\gamma$-Aminobutyric acid production by culturable bacteria from the human intestine. J. Appl. Microbiol. 113, 411-417.

Bodas, R., Manso, T., Mantecón, A.R., Juárez, M., De la Fuente, M.A., Gómez-Cortés, P., 2010. Comparison of the fatty acid profiles in cheeses from ewes fed diets supplemented with different plant oils. J. Agric. Food Chem. 58, 10493-10502.

Cabiddu, A., Decandia, M., Addis, M., Piredda, G., Pirisi, A., Molle, G., 2005. Managing Mediterranean pastures in order to enhance the level of beneficial fatty acids in sheep milk. Small Rumin. Res. 59, 169-180.

Chen, W., 2012. Purification and characterization of a linoleate isomerase from Lactobacillus plantarum ZS2058. African J. Biotechnol. 11, 4579-4587.

Chilliard, Y., Glasser, F., Ferlay, A., Bernard, L., Rouel, J., Doreau, M., 2007. Diet, rumen biohydrogenation and nutritional quality of cow and goat milk fat. Eur. J. Lipid Sci. Technol. 109, 828-855.

Coakley, M., Johnson, M.C., McGrath, E., Rahman, S., Ross, R.P., Fitzgerald, G.F., Devery, R., Stanton, C., 2006. Intestinal bifidobacteria that produce trans-9, trans-11 conjugated linoleic acid: a fatty acid with antiproliferative activity against human colon SW480 and HT-29 cancer cells. Nutr. Cancer 56, 95-102.

Cotter, P.D., Hill, C., 2003. Surviving the acid test: responses of gram-positive bacteria to low pH. Microbiol. Mol. Biol. Rev. 67, 429-453.

Couvreur, S., Hurtaud, C., Lopez, C., Delaby, L., Peyraud, J.L., 2006. The linear relationship between the proportion of fresh grass in the cow diet, milk fatty acid composition, and butter properties. J. Dairy Sci. 89, 1956-1969. 
De La Fuente, L.F., Barbosa, E., Carriedo, J.A., Gonzalo, C., Arenas, R., Fresno, J.M., San Primitivo, F., 2009. Factors influencing variation of fatty acid content in ovine milk. J. Dairy Sci. 92, 3791-3799.

Dewhurst, R.J., Scollan, N.D., Youell, S.J., Tweed, J.K.S., Humphreys, M.O., 2001. Influence of species, cutting date and cutting interval on the fatty acid composition of grasses. Grass Forage Sci. 56, 68-74.

Dhakal, R., Bajpai, V.K., Baek, K.H., 2012. Production of GABA (gamma-aminobutyric acid) by microorganisms: a review. Brazilian J. Microbiol. 43, 1230-1241.

Diana, M., Quílez, J., Rafecas, M., 2014a. Gamma-aminobutyric acid as a bioactive compound in foods: a review. J. Funct. Foods 10, 407-420.

Diana, M., Rafecas, M., Arco, C., Quílez, J., 2014b. Free amino acid profile of Spanish artisanal cheeses: importance of gamma-aminobutyric acid (GABA) and ornithine content. J. Food Compos. Anal. 35, 94-100.

Diezhandino, I., Fernández, D., González, L., McSweeney, P.L.H., Fresno, J.M., 2015. Microbiological, physico-chemical and proteolytic changes in a Spanish blue cheese during ripening (Valdeón cheese). Food Chem. 168, 134-141.

dos Santos, K.M.O., Bomfim, M.A.D., Vieira, A.D.S., Benevides, S.D., Saad, S.M.I., Buriti, F.C.A., Egito, A.S., 2012. Probiotic caprine Coalho cheese naturally enriched in conjugated linoleic acid as a vehicle for Lactobacillus acidophilus and beneficial fatty acids. Int. Dairy J. 24, 107-112.

Ecker, J., Liebisch, G., Patsch, W., Schmitz, G., 2009. The conjugated linoleic acid isomer trans-9,trans-11 is a dietary occurring agonist of liver $\mathrm{X}$ receptor a. Biochem. Biophys. Res. Commun. 388, 660-666.

El-Salam, M.H.A., El-Shafei, K., Sharaf, O.M., Effat, B.A., El-Aasar, M., 2010. Screening of some potentially probiotic lactic acid bacteria for their ability to synthesis conjugated linoleic acid. Int. J. Dairy Technol. 63, 62-69.

El-Salam, M.H.A., El-Shibiny, S., 2014. Conjugated linoleic acid and vaccenic acid contents in cheeses: an overview from the literature. J. Food Compos. Anal. 33, 117126.

Everett, D.W., Auty, M.A.E., 2008. Cheese structure and current methods of analysis. Int. Dairy J. 18, 759-773.

Fernández, D., Arenas, R., Tornadijo, M.E., Ferrazza, R.E., Fresno, J.M., 2012. Zamorano cheese, in: Hui, Y.H., Evranuz, Ö.E. (Eds.), Handbook of Animal-Based Fermented Food and Beverage Technology. CRC Press, Boca Ratón, Florida, pp. 451-472.

Fox, P.F., Guinee, T.P., Cogan, T.M., McSweeney, P.L.H., 2016. Biochemistry of cheese ripening, in: Fundamentals of Cheese Science. Springer, New York, pp. 391-443.

González, L., Cuadrillero, A., Castro, J.M., Bernardo, A., Tornadijo, M.E., 2015. Selection of lactic acid bacteria isolated from San Simón da Costa Cheese (PDO) in order to develop an autochthonous starter culture. Adv. Microbiol. 5, 748-759.

González, L., Sacristán, N., Arenas, R., Fresno, J.M., Tornadijo, M.E., 2010. Enzymatic activity of lactic acid bacteria (with antimicrobial properties) isolated from a traditional Spanish cheese. Food Microbiol. 27, 592-597.

González, L., Sandoval, H., Sacristán, N., Castro, J.M., Fresno, J.M., Tornadijo, M.E., 2007. Identification of lactic acid bacteria isolated from Genestoso cheese throughout ripening and study of their antimicrobial activity. Food Control 18, 716-722. 
Gorissen, L., Raes, K., Weckx, S., Dannenberger, D., Leroy, F., De Vuyst, L., De Smet, S., 2010. Production of conjugated linoleic acid and conjugated linolenic acid isomers by Bifidobacterium species. Appl. Microbiol. Biotechnol. 87, 2257-2266.

Gorissen, L., Weckx, S., Vlaeminck, B., Raes, K., De Vuyst, L., De Smet, S., Leroy, F., 2011. Linoleate isomerase activity occurs in lactic acid bacteria strains and is affected by $\mathrm{pH}$ and temperature. J. Appl. Microbiol. 111, 593-606.

Griinari, J.M., Corl, B.A., Lacy, S.H., Chouinard, P.Y., Nurmela, K. V, Bauman, D.E., 2000. Conjugated linoleic acid is synthesized endogenously in lactating dairy cows by $\Delta 9$ desaturase. J. Nutr. 130, 2285-91.

Guarcello, R., De Angelis, M., Settanni, L., Formiglio, S., Gaglio, R., Minervini, F., Moschetti, G., Gobbetti, M., 2016. Selection of amine-oxidizing dairy lactic acid bacteria and identification of the enzyme and gene involved in the decrease of biogenic amines. Appl. Environ. Microbiol. 82, 6870-6880.

Guinee, T.P., Fox, P.F., 2004. Salt in cheese: physical, chemical and biological aspects, in: Fox, P.F., McSweeney, P.L.H., Cogan, T.M., Guinee, T.P. (Eds.), Cheese: Chemistry, Physics and Microbiology. Elsiever Academic Press, London, pp. 207-259.

Hejtmánková, A., Pivec, V., Trnková, E., Dragounová, H., 2012. Differences in the composition of total and whey proteins in goat and ewe milk and their changes throughout the lactation period. Czech J. Anim. Sci. 57, 323-331.

Herreros, M.A., Fresno, J.M., González Prieto, M.J., Tornadijo, M.E., 2003. Technological characterization of lactic acid bacteria isolated from Armada cheese (a Spanish goats' milk cheese). Int. Dairy J. 13, 469-479.

Hervás, G., Luna, P., Mantecón, A.R., Castañares, N., de la Fuente, M.A., Juárez, M., Frutos, P., 2008. Effect of diet supplementation with sunflower oil on milk production, fatty acid profile and ruminal fermentation in lactating dairy ewes. J. Dairy Res. 75, 399.

Jiang, J., Björck, L., Fondén, R., 1998. Production of conjugated linoleic acid by dairy starter cultures. J. Appl. Microbiol. 85, 95-102.

Kalač, P., Samková, E., 2010. The effects of feeding various forages on fatty acid composition of bovine milk fat: A review. Czech J. Anim. Sci. 55, 521-537.

Komatsuzi, N., Nakamura, T., Kimura, T., Shima, J., 2008. Characterization of glutamate decarboxylase from a high $\gamma$-aminobutyric acid (GABA)-producer, Lactobacillus paracasei. Biosci. Biotechnol. Biochem. 72, 278-285.

Kurata, K., Nagasawa, M., Tomonaga, S., Aoki, M., Akiduki, S., Morishita, K., Denbow, D.M., Furuse, M., 2012. Orally administered 1-ornithine reduces restraint stressinduced activation of the hypothalamic-pituitary-adrenal axis in mice. Neurosci. Lett. 506, 287-291.

Laskaridis, K., Serafeimidou, A., Zlatanos, S., Gylou, E., Kontorepanidou, E., Sagredos, A., 2013. Changes in fatty acid profile of feta cheese including conjugated linoleic acid. J. Sci. Food Agric. 93, 2130-2136.

Li, H., Li, W., Liu, X., Cao, Y., 2013. gadA gene locus in Lactobacillus brevis NCL912 and its expression during fed-batch fermentation. FEMS Microbiol. Lett. 349, 108-116.

Linares, D.M., del Rio, B., Redruello, B., Ladero, V., Martin, M.C., Fernandez, M., RuasMadiedo, P., Alvarez, M.A., 2016. Comparative analysis of the in vitro cytotoxicity of the dietary biogenic amines tyramine and histamine. Food Chem. 197, 658-663. 
Linares, D.M., Martín, M., Ladero, V., Alvarez, M.A., Fernández, M., 2011. Biogenic amines in dairy products. Crit. Rev. Food Sci. Nutr. 51, 691-703.

Lock, A.L., Garnsworthy, P.C., 2003. Seasonal variation in milk conjugated linoleic acid and $\Delta 9$-desaturase activity in dairy cows. Livest. Prod. Sci. 79, 47-59.

Luna, P., Juárez, M., de la Fuente, M.A., 2007. Conjugated linoleic acid content and isomer distribution during ripening in three varieties of cheeses protected with designation of origin. Food Chem. 103, 1465-1472.

Lurueña-Martinez, M.A., Revilla, I., Severiano- Pérez, P., VivarQuintana, A.M., 2010. The influence of breed on the organoleptic characteristics of Zamorano sheep's raw milk cheese and its assessment by instrumental analysis. Int. J. Dairy Technol. 63, 216223.

Madrau, M.A., Mangia, N.P., Murgia, M.A., Sanna, M.G., Garau, G., Leccis, L., Caredda, M., Deiana, P., 2006. Employment of autochthonous microflora in Pecorino Sardo cheese manufacturing and evolution of physicochemical parameters during ripening. Int. Dairy J. 16, 876-885.

Manca, G., Porcu, A., Ru, A., Salaris, M., Franco, M.A., De Santis, E.P.L., 2015. Comparison of $\gamma$-aminobutyric acid and biogenic amine content of different types of ewe's milk cheese produced in Sardinia, Italy. Ital. J. Food Saf. 4, 4700.

Mangia, N.P., Murgia, M.A., Garau, G., Sanna, M.G., Deiana, P., 2008. Influence of selected lab cultures on the evolution of free amino acids, free fatty acids and Fiore Sardo cheese microflora during the ripening. Food Microbiol. 25, 366-377.

Mele, M., Contarini, G., Cercaci, L., Serra, A., Buccioni, A., Povolo, M., Conte, G., Funaro, A., Banni, S., Lercker, G., Secchiari, P., 2011. Enrichment of Pecorino cheese with conjugated linoleic acid by feeding dairy ewes with extruded linseed: Effect on fatty acid and triglycerides composition and on oxidative stability. Int. Dairy J. 21, 365372.

Mohan, M.S., Anand, S., Kalscheur, K.F., Hassan, A.N., Hippen, A.R., 2013. Starter cultures and cattle feed manipulation enhance conjugated linoleic acid concentrations in Cheddar cheese. J. Dairy Sci. 96, 2081-2094.

Nagao, K., Yanagita, T., 2010. Medium-chain fatty acids: functional lipids for the prevention and treatment of the metabolic syndrome. Pharmacol. Res. 61, 208-212.

Narayan, V.S., Nair, P.M., 1990. Metabolism, enzymology and possible roles of 4aminobutyrate in higher plants. Phytochemistry 29, 367-375.

Nieuwenhove, V.C.P., Oliszewski, R., González, S.N., Pérez Chaia, A.B., 2007a. Influence of bacteria used as adjunct culture and sunflower oil addition on conjugated linoleic acid content in buffalo cheese. Food Res. Int. 40, 559-564.

Nieuwenhove, V.C.P., Oliszewski, R., González, S.N., Pérez Chaia, A.B., 2007b. Conjugated linoleic acid conversion by dairy bacteria cultured in MRS broth and buffalo milk. Lett. Appl. Microbiol. 44, 467-474.

Nomura, M., Nakajima, I., Fujita, Y., Kobayashi, M., Kimoto, H., Suzuki, I., Aso, H., 1999. Lactococcus lactis contains only one glutamate decarboxylase gene. Microbiology 145, 1375-1380.

Novella-Rodriguez, S., Veciana-Nogues, M.T., Izquierdo-Pulido, M., Vidal-Carou, M.C., 2003. Distribution of biogenic amines and polyamines in cheese. J. Food Sci. 68, 750-756. 
Nudda, A., McGuire, M.A., Battacone, G., Pulina, G., 2005. Seasonal variation in conjugated linoleic acid and vaccenic acid in milk fat of sheep and its transfer to cheese and Ricotta. J. Dairy Sci. 88, 1311-1319.

O’Reilly, C.E., Kelly, A.L., Oliveira, J.C., Murphy, P.M., Auty, M.A.E., Beresford, T.P., 2003. Effect of varying high-pressure treatment conditions on acceleration of ripening of cheddar cheese. Innov. Food Sci. Emerg. Technol. 4, 277-284.

Ogawa, J., Kishino, S., Ando, A., Sugimoto, S., Mihara, K., Shimizu, S., 2005. Production of conjugated fatty acids by lactic acid bacteria. J. Biosci. Bioeng. 100, 355-364.

Ogawa, J., Matsumura, K., Kishino, S., Omura, Y., Shimizu, S., 2001. Conjugated linoleic acid accumulation via 10-hydroxy-12-octadecaenoic acid during microaerobic transformation of linoleic acid by Lactobacillus acidophilus. Appl. Environ. Microbiol. $67,1246-1252$.

Okada, T., Sugishita, T., Murakami, T., Murai, H., Saikusa, T., Horino, T., Onoda, A., Kajimoto, O., Takahashi, R., Takahashi, T., 2000. Effect of the defatted rice germ enriched with GABA for sleeplessness, depression, autonomic disorder by oral administration. J. Japanese Soc. Food Sci. Technol. 47, 596-603.

Parodi, P.W., 2004. Milk fat in human nutrition. Aust. J. Dairy Technol. 59, 3.

Pinho, O., Mendes, E., Alves, M.M., Ferreira, I.M.P.L.V.O., 2004. Chemical, physical, and sensorial characteristics of "Terrincho" ewe cheese: changes during ripening and intravarietal comparison. J. Dairy Sci. 87, 249-257.

Piras, C., Cesare Marincola, F., Savorani, F., Engelsen, S.B., Cosentino, S., Viale, S., Pisano, M.B., 2013. A NMR metabolomics study of the ripening process of the Fiore Sardo cheese produced with autochthonous adjunct cultures. Food Chem. 141, 2137-2147.

Pouliot-Mathieu, K., Gardner-Fortier, C., Lemieux, S., St-Gelais, D., Champagne, C.P., Vuillemard, J.C., 2013. Effect of cheese containing gamma-aminobutyric acidproducing lactic acid bacteria on blood pressure in men. PharmaNutrition 1, 141148.

Poveda, J.M., Cabezas, L., McSweeney, P.L.H., 2004. Free amino acid content of Manchego cheese manufactured with different starter cultures and changes throughout ripening. Food Chem. 84, 213-218.

Poveda, J.M., Chicón, R., Cabezas, L., 2015. Biogenic amine content and proteolysis in Manchego cheese manufactured with Lactobacillus paracasei subsp. paracasei as adjunct and other autochthonous strains as starters. Int. Dairy J. 47, 94-101.

Renes, E., Diezhandino, I., Fernández, D., Ferrazza, R.E., Tornadijo, M.E., Fresno, J.M., 2014. Effect of autochthonous starter cultures on the biogenic amine content of ewe's milk cheese throughout ripening. Food Microbiol. 44, 271-277.

Renna, M., Cornale, P., Lussiana, C., Malfatto, V., Mimosi, A., Battaglini, L.M., 2012. Fatty acid profile of milk from goats fed diets with different levels of conserved and fresh forages. Int. J. Dairy Technol. 65, 201-207.

Rodríguez-Alcalá, L.M., Braga, T., Malcata, X.F., Gomes, A., Fontecha, J., 2011. Quantitative and qualitative determination of CLA produced by Bifidobacterium and lactic acid bacteria by combining spectrophotometric and Ag+-HPLC techniques. Food Chem. 125, 1373-1378.

Schillinger, U., Lücke, F.K., 1989. Antibacterial activity of Lactobacillus sake isolated from 
meat. Appl. Environ. Microbiol. 55, 1901-1906.

Schirone, M., Tofalo, R., Fasoli, G., Perpetuini, G., Corsetti, A., Manetta, A.C., Ciarrocchi, A., Suzzi, G., 2013. High content of biogenic amines in Pecorino cheeses. Food Microbiol. 34, 137-144.

Settanni, L., Moschetti, G., 2010. Non-starter lactic acid bacteria used to improve cheese quality and provide health benefits. Food Microbiol. 27, 691-697.

Siragusa, S., De Angelis, M., Di Cagno, R., Rizzello, C.G., Coda, R., Gobbetti, M., 2007. Synthesis of gamma-aminobutyric acid by lactic acid bacteria isolated from a variety of Italian cheeses. Appl. Environ. Microbiol. 73, 7283-90.

Stanton, C., Murphy, J., McGrath, E., Devery, R., 2003. Animal feeding strategies for conjugated linoleic acid enrichment of milk, in: Sebedio, J.L., Christie, W.W., Adlof, R. (Eds.), Advances in Conjugated Linoleic Acid Research. AOCS Press, Champaign IL (USA), pp. 123-145.

Sugino, T., Shirai, T., Kajimoto, Y., Kajimoto, O., 2008. 1-Ornithine supplementation attenuates physical fatigue in healthy volunteers by modulating lipid and amino acid metabolism. Nutr. Res. 28, 738-743.

Swanson, D., Block, R., Mousa, S.A., 2012. Omega-3 fatty acids EPA and DHA: health benefits throughout life. Adv. Nutr. An Int. Rev. J. 3, 1-7.

Taboada, N., Van Nieuwenhove, C., Alzogaray, S.L., Medina, R., 2015. Influence of autochthonous cultures on fatty acid composition, esterase activity and sensory profile of Argentinean goat cheeses. J. Food Compos. Anal. 40, 86-94.

ten Brink, B., Damink, C., Joosten, H.M.L.J., Huis in 't Veld, J.H.J., 1990. Occurrence and formation of biologically active amines in foods. Int. J. Food Microbiol. 11, 73-84.

Terán, V., Pizzarro, P.L., Zacarías, M.F., Vinderola, G., Medina, R., Van Nieuwenhove, C., 2015. Production of conjugated dienoic and trienoic fatty acids by lactic acid bacteria and bifidobacteria. J. Funct. Foods 19, 417-425.

Tsiplakou, E., Kominakis, A., Zervas, G., 2008. The interaction between breed and diet on CLA and fatty acids content of milk fat of four sheep breeds kept indoors or at grass. Small Rumin. Res. 74, 179-187.

Tsiplakou, E., Mountzouris, K.C., Zervas, G., 2006. Concentration of conjugated linoleic acid in grazing sheep and goat milk fat. Livest. Sci. 103, 74-84.

Turpeinen, A.M., Mutanen, M., Aro, A., Salminen, I., Basu, S., Palmquist, D.L., Griinari, J.M., 2002. Bioconversion of vaccenic acid to conjugated linoleic acid in humans. Am. J. Clin. Nutr. 76, 504-510.

Valsamaki, K., Michaelidou, A., Polychroniadou, A., 2000. Biogenic amine production in Feta cheese. Food Chem. 71, 259-266.

Wang, L.M., Lv, J.P., Chu, Z.Q., Cui, Y.Y., Ren, X.H., 2007. Production of conjugated linoleic acid by Propionibacterium freudenreichii. Food Chem. 103, 313-318.

Wu, Q., Shah, N.P., 2017. High $\gamma$-aminobutyric acid production from lactic acid bacteria: Emphasis on Lactobacillus brevis as a functional dairy starter. Crit. Rev. Food Sci. Nutr. 57.

Wu, Q., Shah, N.P., 2015. Gas release-based prescreening combined with reversed-phase HPLC quantitation for efficient selection of high- $\gamma$-aminobutyric acid (GABA)producing lactic acid bacteria. J. Dairy Sci. 98, 790-797.

Yang, B., Chen, H., Stanton, C., Ross, R.P., Zhang, H., Chen, Y.Q., Chen, W., 2015. Review 
of the roles of conjugated linoleic acid in health and disease. J. Funct. Foods 15, 314-325.

Zhang, Y., Song, L., Gao, Q., Yu, S.M., Li, L., Gao, N.F., 2012. The two-step biotransformation of monosodium glutamate to GABA by Lactobacillus brevis growing and resting cells. Appl. Microbiol. Biotechnol. 94, 1619-1627.

Zlatanos, S., Laskaridis, K., Feist, C., Sagredos, A., 2002. CLA content and fatty acid composition of Greek Feta and hard cheeses. Food Chem. 78, 471-477. 



\section{CONCLUSIONES}

PRIMERA. Actualmente la producción de leche de oveja se ha intensificado dando menor importancia al valor nutricional de la misma. Sin embargo, prácticas de manejo menos intensivas basadas en un mayor pastoreo de las ovejas en detrimento de las dietas basadas en forraje y concentrado, no supondrían una inversión económica elevada para los ganaderos, mejorarian la calidad de la leche y en consecuencia, el valor nutricional del queso. Por consiguiente, este aspecto sería de gran interés para la industria láctea.

SEGUNDA. Considerando los efectos beneficiosos sobre la salud humana del CLA y del GABA, el desarrollo de cultivos lácticos constituidos por cepas autóctonas con capacidad demostrada para sintetizar estos compuestos bioactivos, puede hallar aplicación en la elaboración de productos lácteos funcionales.

TERCERA. Los cultivos compuestos por cepas de Lactobacillus productoras de CLA en combinación con cepas de Lactococcus lactis autóctonas, fueron más efectivos en la producción de CLA que los cultivos que incluyeron cepas comerciales de Lactococcus lactis y los Lactobacillus productores de CLA.

CUARTA. El cultivo autóctono compuesto por cepas de Lactococcus lactis y la combinación de las cepas productoras de CLA, Lactobacillus plantarum TAUL 1588 y Lactobacillus casei subsp. casei SS1644, mejoró la calidad nutricional de la grasa del queso de oveja en relación con los ácidos grasos con efectos beneficiosos sobre la salud humana. Este hecho es de gran interés ya que permitiría satisfacer la demanda de los consumidores en lo que respecta a alimentos más saludables y con unas buenas características sensoriales.

QUINTA. Los quesos de oveja elaborados con los cultivos autóctonos que incluyeron la cepa de Lactobacillus plantarum mostraron un elevado contenido en GABA y una baja concentración en aminas biógenas, constituyendo una buena aproximación para el desarrollo de quesos de oveja funcionales.

SEXTA. Este trabajo demuestra la gran importancia que tienen las prácticas de manejo del ganado ovino en el perfil de la grasa láctea así como el interés de diseñar cultivos lácticos con capacidad para sintetizar compuestos bioactivos con efectos beneficiosos sobre la salud humana en el desarrollo de productos lácteos con calidad nutricional mejorada. 



\section{CONCLUSIONS}

FIRST. Currently, sheep milk production is being intensified giving less importance to the nutritional value of the milk. However, less intensive sheep management practices based on higher sheep grazing instead of forage- and concentrate-based diets, would not mean high capital investment for farmers, it would lead to an improvement in sheep milk quality and consequently, in the nutritional value of cheese. Therefore, this aspect would be of great interest to the dairy industry.

SECOND. Considering the health benefits of CLA and GABA, the development of lactic cultures constituted by autochthonous strains with demonstrated ability to produce these bioactive compounds, could contribute to the production of functional dairy products.

THIRD. Cultures including Lactobacillus CLA-producing strains in combination with autochthonous Lactococcus lactis strains, were more effective on CLA production than the cultures including commercial Lactococcus lactis strains and the CLA-producers Lactobacillus.

FOURTH. The autochthonous culture including the Lactococcus lactis strains and the combination of both CLA-producers strains, Lactobacillus plantarum TAUL 1588 and Lactobacillus casei subsp. casei SS1644, improved the nutritional quality of sheep milk cheese fat in relation to the fatty acids with beneficial effects on human health. This fact is of great interest in order to meet consumer demand for healthier foods with good sensory characteristics.

FIFTH. Sheep milk cheeses produced with the autochthonous cultures including the Lactobacillus plantarum TAUL 1588 strain showed high GABA content and low biogenic amines concentration, being a good approach to develop functional sheep milk cheeses.

SIXTH. This work shows the great importance of sheep management practices on the milk fat profile as well as the relevance of designing lactic cultures with ability to synthesize bioactive compounds with beneficial effects on human health in order to develop dairy products with improved nutritional quality. 

